

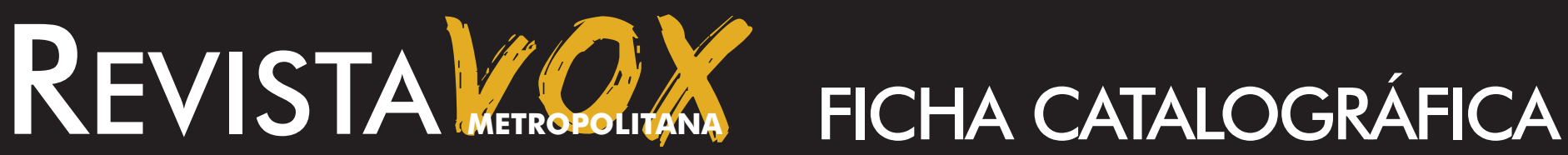

Revista Vox Metropolitana [Recurso eletrônico] / Faculdade Metropolitana da Grande Recife. - n. 5 - Jaboatão dos Guararapes: FMGR, 2021.

Semestral

ISSN: 2674-8673

Disponível em: https://revistavox.metropolitana.edu.br

1. Produção acadêmica - Periódicos. 2. Faculdade Metropolitana da Grande Recife. I. Título

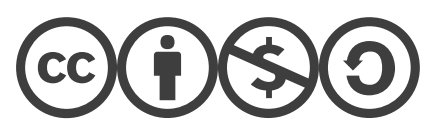




\section{REVISTAVOXX}

\section{APRESENTAÇÃO}

A Revista Vox Metropolitana é uma publicação semestral da Faculdade Metropolitana da Grande Recife (FMGR) voltada para a publicação de trabalhos acadêmicos por parte de professores e alunos dos cursos de graduação e pós-graduação desta e de outras instituições de ensino.

A Revista Vox Metropolitana está aberta para publicações de artigos originais ou de revisão, e relatos de experiências no formato de artigo científico.

Sua natureza apresenta foco multidisciplinar, publicando trabalhos diversos e resultados de pesquisas realizadas nas mais diversas áreas da ciência.

Revista Vox Metropolitana

https://revistavox.metropolitana.edu.br revistavox@metropolitana.edu.br

Faculdade Metropolitana da Grande Recife

Av. Barreto de Menezes, 809, Piedade Jaboatão dos Guararapes/PE

CEP: 54.410-100

Fones: 08005000500 (81) 2128-0500

Site: www.metropolitana.edu.br

Redes Sociais: instagram.com/fmgrecife 


\section{REVISTA Y OXY}

\section{CORPO EDITORIAL}

\section{Editor Chefe}

- Arandi Maciel Campelo

\section{Conselho Editorial}

- Anderson Dacal Rocha (Mantenedor/Diretor Financeiro)

- Arandi Maciel Campelo

- Eline Isobel da Cunha Souza (Bibliotecária)

- Eronildo Ferreira do Carmo (Revisor - gramatical)

- Julio Miranda Vidal (Director Docente de Ingeniería en Administración, Universidad Mayor/Chile)

- Valber Marcel Bueno (Mantenedor / Diretor de Gestão de Ensino / Revisor diagramação)

\section{Comissão Editorial}

- Anderson Dacal Rocha (Mantenedor/Diretor Financeiro)

- Carlos Augusto da Silva Cavalcanti

- Eline Isobel da Cunha Souza (Bibliotecária)

- Erinaldo Ferreira do Carmo (Docente Convidado da Universidade Federal de Pernambuco - UFPE)

- Eronildo Ferreira do Carmo (Revisor - gramatical)

- Fabiana Maria da Silva (Pesquisadora Institucional)

- Fábio José de Araújo Pedrosa (Docente Convidado da Universidade de Pernambuco - UPE)

- Gleydson Rocha de Souza (Coordenador da Escola de Saúde / Coordenador do Núcleo de Educação a Distância)

- Hermes Magalhães Junior (Coordenador da Escola de Gestão / Coordenador da Escola de Engenharia)

- Julio Miranda Vidal (Director Docente de Ingeniería en Administración, Universidad Mayor/Chile)

- Kariane Maria Arruda Vasconcelos (Secretária Acadêmica)

- Sthênio José Ferraz Magalhães (Coordenador da Escola de Ensino)

- Valber Marcel Bueno (Mantenedor / Diretor de Gestão de Ensino / Revisor diagramação) 


\section{REVISTA Y OXY}

\section{SUMÁRIO}

01 - Comunicação Empresarial: desafios entre os setores de compras e comercial em uma empresa de produtos odontológicos

02 - Comunicação verbal e não verbal: fatores que influenciam as relações entre líderes e liderados

03 - Conciliação: instrumento de celeridade e equilíbrio processual na Justiça do Trabalho

04 - Cultura e clima organizacional: influência na qualidade de vida no trabalho

05 - Dificuldade de aprendizagem na leitura e na escrita de alunos do $2 \circ$ ano do Ensino Fundamental I

06 - E-Commerce: desafios na captação de clientes em uma loja do segmento de essências

07 - Educação Ambiental na Educação Infantil

08 -Efeitos do treinamento resistido na força muscular em idosos com sarcopenia: estudo de revisão literária

09 - Evaluación de desempeño y alineamento estratégico: bases para una formulación métrica

10 - Avaliação de desempenho e alinhamento estratégico: bases para uma formulação métrica

11 - Feminicídio: crime hediondo contra a mulher

12 - Inovação e mudanças de paradigmas através da Gestão 4.0 na busca do diferencial competitivo nas organizações

13 - A Logística Reversa contribuindo para a mitigação dos impactos ambientais: um estudo de caso

14 - Marketing Digital na captação e fidelização de clientes: a visão de alunos do curso de Administração de uma Instituição de Ensino Superior

15 - Metodologias Ativas na Educação de Jovens e Adultos: um estudo bibliográfico

16 - Tecnologia da Informação como ferramenta para a logística

17 - Teletrabalho e suas complexidades 


\title{
COMUNICAÇÃO EMPRESARIAL: DESAFIOS ENTRE OS SETORES DE COMPRAS E COMERCIAL EM UMA EMPRESA DE PRODUTOS E EQUIPAMENTOS ODONTOLÓGICOS
}

\author{
https://dx.doi.org/10.48097/2674-8673.2021n5p01
}

\author{
Arandi Maciel Campelo ${ }^{1}$ \\ Roseane Cordeiro Estima dos Santos ${ }^{2}$
}

\section{RESUMO}

Este artigo trata da metodologia de trabalho, nos setores de compras e comercial, exercida em uma empresa de produtos e equipamentos odontológicos. O estudo teve como objetivo explorar possíveis erros, contemplando aspectos tão comuns ao dia a dia, mas que vem se tornando um tema preocupante no âmbito profissional, como a comunicação empresarial. O trabalho também visa buscar melhorias para a execução dos processos em todos os setores, com o intuito de alavancar as vendas e manter um estoque de acordo com a necessidade, obtendo maior retorno financeiro, melhores prazos de pagamentos e entregas. Foram realizadas pesquisas bibliográfica e de campo, aplicada, sendo utilizado um questionário semiaberto, abordando assuntos direcionados ao desenvolvimento pessoal, profissional e empresarial. Os principais teóricos, que balizaram este artigo foram Mitsutani (2017), Dias (2017) e Holmes (2012). A pesquisa de campo foi relizada em um empresa de produtos e equipamentos odontológicos localizada na cidade de Recife, em 2020. A amostragem contemplou 6 dos 45 funcionários, sendo cada um responsável por um setor da empresa. A análise revelou que a liderança estava preocupada e, ao mesmo tempo, disposta a mudar e a contribuir para a evolução da organização.

Palavras-chave: Comunicação empresarial. Estratégias de melhorias. Comunicação entre setores.

Data de submissão: 09/02/2021

Data de aprovação: 11/03/2021

\begin{abstract}
This article deals with the work methodology, in the purchasing and commercial sectors, exercised in a dental products and equipment company. The study aimed to explore possible errors, contemplating aspects that are so common to everyday life, but which has become a matter of concern in the professional sphere, such as business communication. The work also

\footnotetext{
${ }^{1}$ Orientador. Doutor em Educação - Universidade Federal de Pernambuco; Administrador - Universidade de Pernambuco - FCAP/UPE; Mestre em Planificación y Gestion Organizacional - Universidad Autonoma de Madrid / Espanha; Mestre em Dirección y Organización de Hospitales y Servicios de Salud - Universidad Politécnica de Valencia / Espanha; Especialista em Marketing - FCAP/UPE; Consultor em Sistemas Organizacionais desde 1984; Professor e Diretor Acadêmico da Faculdade Metropolitana da Grande Recife.

E-mail: arandi.campelo@globo.com

${ }^{2}$ Estudante do curso de Administração da Faculdade Metropolitana da Grande Recife.

E-mail: roseestima@gmail.com
} 
seeks to seek improvements for the execution of processes in all sectors, in order to leverage sales and maintain a stock according to need, obtaining greater financial return, better payment and delivery terms. Bibliographic and field research was carried out, applied, using a semiopen questionnaire, addressing issues aimed at personal, professional and business development. The main authors included in this article were Mitsutani (2017), Dias (2017) and Holmes (2012). The field research took place in a dental equipment company in 2020 in Recife city. The sample included 6 of the 45 employees, each responsible for a sector of the company. The analysis revealed that the leadership was concerned and, at the same time, willing to change and contribute to the evolution of the organization.

Keywords: Business communication. Improvement strategies. Communication between sectors.

\section{INTRODUÇÃO}

Este artigo foi apresentado à banca de TCC do curso de Administração da Faculdade Metropolitana da Grande Recife, no semestre 2020.2, abordando a comunicação empresarial e os desafios entre o setor de compras e o setor comercial.

A pesquisa que subsidiou a construção do artigo foi realizada em uma empresa de produtos e equipamentos odontológicos, junto aos supervisores de cada setor.

O tema escolhido foi de grande importância para enfatizar que, independente do porte e do segmento da organização, a Comunicação Empresarial é fundamental em diversos aspectos, sejam eles internos ou externos, gerando consequências negativas quando há a falta da mesma.

\section{REFERENCIAL TEÓRICO}

Diante de tantos meios para o envio de informações, e um crescente avanço na tecnologia, ainda há uma considerável dificuldade de comunicação entre os setores de algumas empresas, o que acaba dificultando a produtividade e a rentabilidade nos negócios.

Pensando nisso, é importante citar alguns aspectos relevantes para a melhoria dos processos, através da experiência obtida em pesquisas feitas e informações de autores renomados como Claudio Mitsutani (2017), Mário Dias (2017) e Chet Holmes (2012).

Partimos do princípio que a comunicação é elemento essencial na formação e desenvolvimento não apenas do ser humano, mas das instituições em geral. Seria um caos pensar em uma sociedade em que não houvesse comunicação.

Como cita Haroldo Pereira (2005), a comunicação é simplesmente o fato de um ser A

transferir uma informação para um ser B. É uma forma natural de um indivíduo interagir com outro(s), compartilhando ideias, pensamentos e intenções. 
A comunicação rege todas as relações humanas. É um processo social básico, pois torna possível a vida em sociedade, e viver em sociedade significa interagir para trocar informações de seu interesse.

\section{COMUNICAÇÃO EMPRESARIAL}

A comunicação empresarial eficaz é indispensável e assume um papel de extrema importância em qualquer organização hoje em dia. É uma ferramenta estratégica, responsável por criar a cultura e fortalecer a identidade da instituição. Assim, o gestor atual deve focar sua atuação nas pessoas (colaboradores e clientes), e não apenas nos produtos ou serviços.

Segundo cita Kendra Mandina Gracie (2010),

uma empresa só sobreviverá se uma boa comunicação estiver presente. O homem produz porque se comunica, pois recebe informações a respeito do seu trabalho e entende exatamente o que deve ser feito. Desta forma, sem uma comunicação eficaz, a empresa não consegue atingir seus objetivos organizacionais. (GRACIE, 2010, p. 9).

Toda organização necessita de gestores e colaboradores que saibam ordenar, pedir, sugerir e opinar. Devem ser funcionários influentes, integrados e informados não só sobre o funcionamento, mas sobre acontecimentos, produtos e serviços que envolvem a empresa. A partir desta necessidade, torna-se indispensável que a comunicação seja eficaz em qualquer instituição.

De acordo com Matos (2009), a comunicação empresarial é a relação da empresa com seus clientes internos e externos. É utilizada na transmissão de informações como procedimentos, normas, processos, resultados, metas, objetivos, intruções, etc. A comunicação empresarial é uma ferramenta estratégica que, se for bem aproveitada, pode garantir o bom funcionamento de uma organização. Portanto, em um mercado cada vez mais competitivo, ela tem o potencial para se tornar uma grande vantagem ou um grande problema.

\section{Dificuldades na comunicação entre setores}

O principal objetivo da comunicação empresarial é aumentar a credibilidade da empresa, melhorar a sua imagem frente ao mercado e colaboradores, assim como aumentar a sua lucratividade, pois sintonizar os interesses entre a empresa e os grupos - internos e externos que são alvos de suas ações, é de grande importância.

Algumas das dificuldades enfrentadas dentro de uma organização, por incrível que pareça, é justamente a falta de comunicação, o que afeta negativamente o engajamento dos 
funcionários, o planejamento entre os setores e até mesmo o comprometimento dos clientes com a marca.

As consequências geradas por falhas na comunicação podem trazer graves problemas para as organizações e na empresa pesquisada não foi diferente.

As ações de vendas e marketing, por exemplo, enquadram-se na categoria da falta de planejamento entre os setores, pois ações como essas eram divulgadas para o consumidor, sem sequer o setor de compras estar ciente.

Com isso, havia um aumento na procura por determinados produtos, especificamente esses que haviam sido divulgados, porém, não tinha estoque o suficiente para atender e suprir a demanda, resultando em uma perda significativa.

O setor de compras é responsável por manter a empresa em pleno funcionamento. Por isso, o correto é realizar os pedidos em tempo hábil junto aos fornecedores e manter um estoque abastecido, de acordo com a necessidade. A área de compras contribui também para que a empresa não pare de lucrar, mas, infelizmente, não era isso que estava acontecendo.

Foi percebido esse gargalo e o diretor de compras e suprimentos (na hierarquia da empresa ele é o único responsável) foi informado sobre a necessidade de comunicação e planejamento entre o setor comercial e o de compras, pois a sua imagem como organização estava sendo questionada e, se fosse tomada alguma providência, os resultados poderiam ser bem diferentes.

No decorrer do tempo tudo continuou do mesmo jeito. A falha na comunicação ainda existia entre a diretoria e, consequentemente, todos os setores eram afetados e a situação vinha se agravando. Percebe-se que com a falta de mudança os gestores e colaboradores se tornaram engessados no modo de trabalhar, achando que a forma como as coisas vinham acontecendo já era "boa" o suficiente.

A empresa pesquisada é de caráter familiar. O superior responsável pelo setor, além de sócio, é o diretor de compras e suprimentos. O irmão dele é diretor comercial e a esposa é diretora financeira. O diretor comercial é responsável pelas ações de vendas e marketing e, na hierarquia, abaixo dele só há os consultores de vendas.

Em uma organização com outros valores, para que essa situação fosse corrigida, antes de pensar em divulgar uma ação de vendas seria necessário planejamento e programação, tendo em vista que para se vender melhor e ter resultados positivos, estabelecer estratégias é imprescindível. Analisar os pontos fortes, fracos, as oportunidades e ameaças, garantem um pouco mais de segurança para o investimento (GOBE, 2017). 
Após reunir todas as informações necessárias, deve-se, junto ao setor de compras, listar os itens que devem ser comprados, qual o melhor momento para venda desses produtos, qual o custo que a empresa terá, a média de preço que será repassada ao cliente, e analisar o prazo de recebimento. Conforme cita Mitsutani (2017): "para comprar bem é fundamental saber o que se está comprando; sendo assim, entender o perfil de demanda, a sazonalidade $^{3}$ e as características técnicas do que é comprado é essencial.” (MITSUTANI, 2017, p. 41).

\section{Processo de compras e o reflexo da comunicação}

Antigamente, o setor de compras não era tão valorizado quanto hoje. Quanto mais o tempo passa, maior a sua visibilidade diante do mercado. Este setor é visto também como parte do processo de logística das empresas, ou seja, como parte integrante da cadeia de suprimentos.

No decorrer dos anos deixou de ser operacional e passou a ser estratégico. Essa mudança deve-se à posição de destaque que a área ganhou, já que a etapa de compras é fundamental para o êxito da empresa. (MITSUTANI, 2017).

Embora, geralmente, a maior preocupação esteja nas vendas, vale salientar que é necessário realizar aquisições de maneira eficiente, já que o sucesso das vendas depende do relacionamento que a companhia mantém com os fornecedores e a qualidade dos produtos e/ou serviços adquiridos, além de permitir vantagem competitiva e otimização de custos.

Conforme explica Dias (2017):

a vantagem competitiva se refere à posição relativa da empresa no mercado consumidor, em termos de competição com as outras empresas integrantes. Podemos dizer que as prioridades competitivas de uma organização são: qualidade, entrega, flexibilidade, atendimento e preço. (DIAS, 2017, p. 12).

Para otimização do processo, os setores de compras e comercial precisam estar muito bem alinhados. $\mathrm{O}$ vai e vem de informações e a falha na comunicação podem gerar erros irreparáveis e pode custar um pouco caro. A falta de comunicação, por exemplo, entre a área de compras e os outros departamentos acaba gerando dados desencontrados.

Situações como essa causam danos bastante consideráveis, principalmente quando são situações específicas, como ações de marketing que para se ter bons resultados e boa lucratividade requer as melhores negociações possíveis e os melhores prazos, pois a busca pelo retorno positivo não acontece de uma hora para outra.

A realidade na empresa pesquisada era outra. Não havia conhecimento de quando essas ações iriam acontecer, resultando em compras de última hora a preços altíssimos, já que não

\footnotetext{
${ }^{3}$ Produto ou serviço sujeito às flutuações de demanda do consumidor, geralmente ao longo de um ano.
} 
tinha o poder de barganha e nem tempo hábil para comparar com o preço da concorrência. Ganhava quem tivesse a entrega mais rápida, consequentemente, com o custo mais alto.

Visando melhorias, alguns processos precisavam ser adotados. O primeiro deles, uma montagem de um calendário de ações para que houvesse uma programação em determinados períodos. Assim, é possível registrar corretamente as entradas e as saídas, padronizar os produtos e as descrições, programar as compras e conhecer os fornecedores, além da utilização de ferramentas como RFPs ${ }^{4}$ e RFQs ${ }^{5}$. Desta forma, é possível alcançar resultados positivos e o gerenciamento de forma integrada.

Adotar esse tipo de controle permitiria a determinação para o prazo médio de compras, possibilitando ao empresário um ótimo custo-benefício e melhor distribuição para os meses seguintes, tendo como base os compromissos assumidos e as previsões de vendas, garantindo uma melhor programação para compras futuras.

Por sua vez, quando não há esse tipo de planejamento e comunicação, faz-se necessário a realização de compras emergenciais (não recomendado), o que gera aos compradores falta de alternativas como negociação, prazo, valores elevados, além da probabilidade de não ter o produto para aquele momento. Isso ocorre quando o solicitante não informa sobre as negociações que estão sendo feitas, resultando em transtornos não só para o cliente, como também para a empresa, de modo geral. Portanto, a comunicação entre setores é indeclinável, principalmente quando envolve comercial e compras. $\mathrm{O}$ alinhamento entre ambos os setores é necessário.

\section{Boas compras, vendas ainda melhores}

Após adotar estratégias e realizar as melhores compras, manter o foco no cliente é imprescindível. A partir do momento que se consegue as melhores negociações é possível também estar na frente da concorrência, oferecendo melhores oportunidades.

A produtividade da força de vendas é um tema cada vez mais recorrente entre empresas atentas aos desafios do mercado atual, pois há uma grande diferença entre o que o mercado pode oferecer e o que o cliente, de fato, busca. Entender as suas necessidades permite a geração de valores e vantagens competitivas.

Empreendedores dos mais diversos setores e segmentos já compreendem que as relações com o consumidor não podem ser gerenciadas como antigamente. $\mathrm{O}$ cliente passou a ser mais

\footnotetext{
${ }^{4}$ Processo de aquisição envolvendo vários fornecedores. Aumenta a capacidade de negociação e o poder de compra das empresas.

${ }^{5}$ Solicitação de cotação envolvendo vários fornecedores. É um processo de licitação para produtos ou serviços específicos.
} 
exigente e aumentou o seu poder de escolha. Com isso, para se adaptar ao novo comportamento do consumidor, não basta seguir a tradicional cartilha do varejo. É preciso fazer mais e melhor, transformando a venda em uma experiência de compra, comunicando-se de forma objetiva e personalizada com o público-alvo, lançando mão da tecnologia sem descuidar do atendimento primoroso.

Aqui, busca-se todo o retorno investido na comunicação empresarial e no processo de compras, mostrando todo o diferencial diante do mercado. Assim, segundo Gobe (2017): "Marketing é o processo de planejar e executar a concepção, o estabelecimento de preços, a promoção e a distribuição de ideias, produtos e serviços, a fim de criar trocas que satisfaçam metas individuais e organizacionais.” (GOBE, 2017, p. 51).

Para uma ação comercial bem sucedida, traçar estratégias faz parte do plano de vendas para gerir o negócio. Dessa forma, consegue-se aumentar a produtividade da equipe e o desempenho de vendas como um todo, gerando retorno financeiro robusto.

Assim como várias outras habilidades, a exemplo da criatividade e do empreendedorismo, a aptidão para as vendas também pode ser desenvolvida. Aqui, se faz presente técnicas para atendimento personalizado e para o alcance das metas traçadas pelo marketing, dividindo-se em 4 fases:

a) Planejamento da equipe de vendas, que consiste na definição dos objetivos, da estratégia e da estrutura da equipe;

b) Gerenciamento da equipe de vendas, por meio do estabelecimento de funções e de cotas para cada vendedor;

c) Harmonização do processo de venda: atendimento, pré-venda, abordagem, sondagem, demonstração do produto, venda adicional e fechamento da venda;

d) Fidelização do relacionamento com o cliente, ou seja, o pós-venda, por meio do desenvolvimento de mecanismos, como por exemplo: $\mathrm{CRM}^{6}$. É importante se manter presente após a realização da venda e acabar com a imagem de que o vendedor só está disponível no momento de vender. Desta forma, trabalha-se de maneira mais inteligente. (HOLMES, 2012).

\section{METODOLOGIA}

A pesquisa que orientou este artigo foi bibliográfica e de campo, aplicada, propositiva e qualitativa. Como método de coleta de dados foi utilizado um questionário semiaberto,

\footnotetext{
${ }^{6}$ Customer Relationship Management, em Português: Gerenciamento de Relacionamento com o Cliente.
} 
abordando assuntos relacionados com o desenvolvimento pessoal, profissional e empresarial de cada participante.

Neste trabalho buscamos observar e abordar a importância da comunicação entre os setores da empresa, citando consequências que a falha ou ausência podem causar, comentando sobre as ferramentas e metodologias de melhorias nesse processo, especificamente:

a) Enfatizar a importância da Comunicação Empresarial;

b) Citar consequências causadas pela falha na comunicação entre os setores de compras e comercial;

c) Sugerir estratégias de melhorias de processos, a partir de uma boa comunicação entre os setores.

\section{DESENVOLVIMENTO DA PESQUISA DE CAMPO}

O campo investigativo deste trabalho acadêmico foi uma empresa de produtos e equipamentos odontológicos localizada na cidade de Recife.

O universo do campo pesquisado foi composto por 45 colaboradores, cuja amostra realizou-se com 6 gestores que desempenham funções de liderança nos seguintes setores:

a) Comercial;

b) Compras;

c) Financeiro;

d) Logística;

e) Recursos Humanos;

f) Televendas.

\section{RESULTADOS DA PESQUISA DE CAMPO}

1. Quais ferramentas você utiliza para incentivar a comunicação empresarial entre os colaboradores?

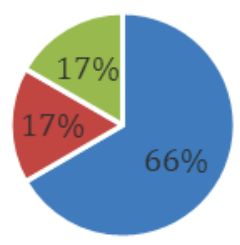

- Reuniões Periodicas

- Caixa de Elogios/Sugestões

- Feedbback Anônimo

Como citado no referencial teórico, a comunicação é essencial para o desempenho da organização. Neste item, percebe-se a predominância das reuniões com expressivos $66 \%$ como principal ferramenta para sua realização entre gestores e colaboradores. 
2. Quais dificuldades empresariais você já enfrentou por falta de comunicação?

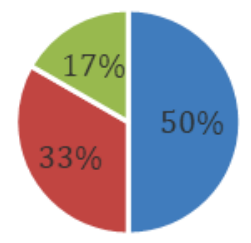

- Informações Divergentes

- Processos mal realizados

- Interpretação Errônea

Esta questão evidencia o que foi abordado no referencial teórico em que cita os principais problemas causados pela falha na comunicação, destacando informações divergentes, com $50 \%$ das respostas.

3. Na sua visão, quais as consequências causadas pela falha na comunicação entre os setores de compras e comercial?

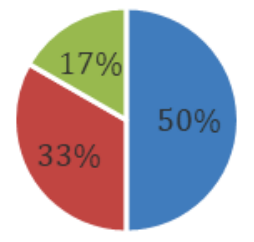

- Má organização dos processos

- Aumento dos custos

- Falta de planejamento

Um dos maiores problemas enfrentados, especificamente, entre os setores de compras e comercial, está na má organização dos processos. $50 \%$ dos participantes citam o mau andamento da empresa por falha na comunicação.

4. Como você mantém um cronograma das suas atividades?
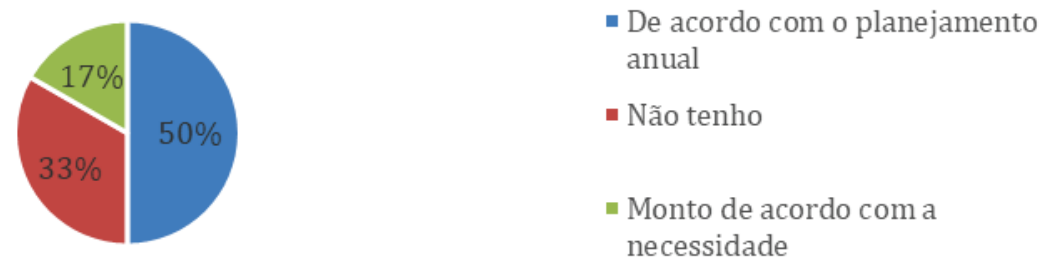

Neste item, percebe-se um destaque de 50\% referente à montagem de um cronograma de atividades anual, o que está de acordo com os autores constantes no refencial teorórico. Porém, ainda há uma quantidade significativa $(33 \%)$ daqueles que nem sequer têm um cronograma, o que mostra um resultado preocupante. 
5. Na sua opinião, o que o cliente busca?

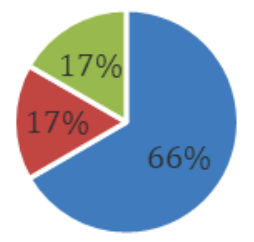

- Atendimento Diferenciado

- Preço

- Qualidade

A maioria dos entrevistados apontou, com $66 \%$ do resultado, que o cliente busca atendimento diferenciado, o que vai de encontro ao que foi citado no referencial teórico, uma vez que entender as necessidades dos clientes permite a geração de valor e vantagens competitivas.

6. Em que aspectos você acha que a fidelização do relacionamento com o cliente acontece?

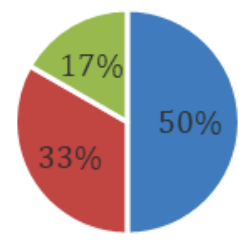

- No pós venda

- No atendimento

- No fechamento da venda

Com $50 \%$ das respostas, o pós-venda foi o aspecto mais citado para a fidelização do relacionamento com o cliente. Essa afirmativa está confirmada por autores como Holmes (2012) ao destacar que é importante se manter presente, após a realização da venda, e acabar com a imagem de que o vendedor só está disponível no momento de vender.

\section{CONSIDERAÇÕES FINAIS}

Após análise da pesquisa ficou evidente as dificuldades enfrentadas pela falta ou falha na comunicação, especificamente entre o setor de compras e o setor comercial. Foi abordada com os gestores envolvidos o quanto é importante essa troca de informações, não apenas dentro de um único setor, mas na organização como um todo. Portanto, é recomendável o planejamento e reuniões com os gestores de cada setor como forma positiva de trazer novas ideias e melhorias nos processos. Foi possível observar que, na maioria das vezes, o problema 
não está em um setor específico, mas um pode prejudicar o processo do outro, acarretando problemas em vários aspectos na organização.

Com base na pesquisa de campo e nas informações dos autores, chegou-se a seguinte conclusão: identificar as dificuldades enfrentadas permitiu que cada colaborador tivesse uma visão mais ampla das necessidades da organização e não apenas do setor que ocupa. Isso facilita o trabalho e o desenvolvimento dos processos, pois setores não devem ser concorrentes, já que estão em busca de objetivos em comum: buscar melhorias, visando o desenvolvimento e o crescimento empresarial, identificando os gargalos, reduzindo custos, fidelizando e aumentando a carteira de clientes.

\section{REFERÊNCIAS}

CARGOX. Gestão de compras: entenda definitivamente como realizar esse processo de forma mais eficiente. Disponível em: https://cargox.com.br/blog/gestao-de-compras-entendadefinitivamente-como-realizar-esse-processo-de-forma-mais-eficiente. Acesso em: 28 mar. 2020 .

DIAS, Mario. Manual do comprador: conceitos, técnicas e práticas indispensáveis em um departamento de compras. São Paulo: Editora Saraiva, 2017.

GOBE, Antonio Carlos. Administração de vendas. São Paulo: Editora Saraiva, 2017.

GRACIE, K. M. Comunicação empresarial: uma ferramenta estratégica. Rio de Janeiro: Universidade Candido Mendes. 2010. Monografia. Pós-graduação em Pedagogia Empresarial. $72 \mathrm{p}$.

HOLMES, Chet. A máquina definitiva de vendas: turbine seu negócio com um foco implacável em 12 estratégias-chave. Rio de Janeiro: Editora Alta Books, 2012.

MATOS, Gustavo Gomes. Comunicação empresarial sem complicação. 2. ed. Barueri: Manole, 2009.

MITSUTANI, Claudio. Compras estratégicas: construa parcerias com fornecedores e gere valor para seus negócios. São Paulo: Editora Saraiva, 2017.

PEREIRA, Haroldo. Curso básico de teoria da comunicação. São Paulo: Quartet, 2005.

SEBRAE. Não basta vender, é preciso planejar e monitorar as atividades. Disponível em: https://www.sebrae.com.br/sites/PortalSebrae/artigos/nao-basta-vender-e-preciso-planejar-e monitorar-as-atividades, 84bc438aflc92410VgnVCM100000b272010aRCRD. Acesso em: 28 mar. 2020. 
SEBRAE. Mercado e vendas. Disponível em:

https://www.sebrae.com.br/sites/PortalSebrae/faq/o-que-e-e-como-elaborar-um-plano-de vendas, 73fd3f7095cbd410VgnVCM1000003b74010aRCRD. Acesso em: 28 mar. 2020.

\section{APÊNDICE A - Modelo de questionário semiaberto aplicado no campo investigativo}

O presente questionário consiste em identificar a importância da comunicação entre os setores da organização pesquisada, bem como as consequências que possíveis falhas ou ausência de comunicação podem causar nos setores de compras e comercial.

1. Quais ferramentas você utiliza para incentivar a comunicação empresarial entre os colaboradores?
a) Reuniões Periódicas
b) Caixa de Elogios/Sugestões
c) Feedback Anônimo
d) Outro:

2. Quais dificuldades empresariais você já enfrentou por falta de comunicação?
a) Interpretação Errônea
b) Informações Divergentes
c) Processos mal realizados
d) Outro:

3. Você costuma fazer uma anális e interna e externa para tomada de decisões?

$\operatorname{Sim}(\quad)$ - Não ( )

4. Com que frequência você realiza treinamentos técnicos entre os colaboradores?
a) Quinzenalmente
b) Mensalmente
c) Semestralmente
d) Outro:

5. Você acha que o setor de compras ganhou mais visibilidade no decorrer do tempo?

$$
\operatorname{Sim}(\text { ) - Não ( ) }
$$

6. Na sua visão, quais as consequências causadas pela falha na comunicação entre os setores de compras e comercial?
a) Falta de planejamento
b) Má organização dos processos
c) Aumento dos custos
d) Outro: 
7. Você acha que o setor de compras reflete no comercial?

$\operatorname{Sim}($ ) - Não ( )

8. Como você mantém um cronograma das suas atividades?

a) Não tenho

b) De acordo com o planejamento anual

c) Monto de acordo com a necessidade

d) Outro:

9. Você acha que o cliente vem se tornando cada vez mais exigente?

$\operatorname{Sim}(\quad)$ - Não ( )

10. Na sua opinião, o que o cliente busca?

a) Atendimento Diferenciado

b) Preço

c) Qualidade

d) Outro:

11. Em que aspectos você acha que a fidelização do relacionamento com o cliente acontece?

a) No atendimento

b) No fechamento da venda

c) No pós-venda

d) Outro:

12. Que melhorias você poderia sugerir para o seu setor que causaria impacto muito positivo para a empresa?

Resposta 1: Metas mais claras e atingíveis.

Resposta 2: Disponibilização de ferramentas de comunicação.

Resposta 3: Organizando a demanda, por ordem, do mais antigo para o mais novo.

Resposta 4: Comunicação objetiva, feedback, oportunidade de aceitação de novos projetos, dentre outras coisas.

Resposta 5: Planejamento objetivo de metas e planos, buscando minimizar $0 \%$ de devedores na empresa.

Resposta 6: Existência de um calendário de ações comerciais para planejamento de compras. 


\title{
COMUNICAÇÃO VERBAL E NÃO VERBAL: FATORES QUE INFLUENCIAM AS RELAÇÕES ENTRE LÍDERES E LIDERADOS
}

\author{
https://dx.doi.org/10.48097/2674-8673.2021n5p02
}

\author{
Arandi Maciel Campelo ${ }^{1}$ \\ Carolina Queiroz da Silva ${ }^{2}$ \\ Débora Andrezza de Melo Lima ${ }^{3}$ \\ Natália Maria Correia e Sousa ${ }^{4}$ \\ Eronildo Ferreira do Carmo ${ }^{5}$
}

\section{RESUMO}

O presente estudo aborda a comunicação verbal e não verbal dentro do ambiente institucional. Foi construído através de pesquisa bibliográfica e coleta de dados com população composta por trabalhadores de trinta setores administrativos, somando noventa e três funcionários, realizada na Faculdade Metropolitana da Grande Recife no período de agosto a novembro de 2020. Apresenta como principal objetivo analisar a comunicação verbal e não verbal dentro do ambiente corporativo. Os referenciais teóricos apresentados para respaldos científicos foram, principalmente, Biderman (2009) e Cardoso (2006). De todo corpo amostral, apenas dezenove funcionários concordaram em participar da pesquisa. Para avaliação dos critérios analisados foi realizada a aplicação de um questionário de caráter qualitativo, através da plataforma Google forms. Os dados do questionário elucidaram possível receio por parte dos funcionários durante a realização da pesquisa, o que pode ter gerado divergências nas respostas, corroborando com o que foi abordado em todo o conteúdo, em que a ausência ou a má formulação da réplica de uma das partes da comunicação reduz a satisfação e a evolução dos processos dentro da empresa.

Palavras-chave: Comunicação empresarial. Cultura e clima organizacional. Linguagem Verbal. Linguagem corporal. Ruídos na comunicação .

Data de submissão: 28/01/2021

Data de aprovação: 22/02/2021

1 Orientador: Doutor em Educação - Universidade Federal de Pernambuco; Administrador - Universidade de Pernambuco - FCAP/UPE; Mestre em Planificación y Gestion Organizacional - UniversidadAutonoma de Madrid / Espanha; Mestre em Dirección y Organización de Hospitales y Servicios de Salud - Universidad Politécnica de Valencia / Espanha; Especialista em Marketing - FCAP/UPE; Consultor em Sistemas Organizacionais, desde 1984; Professor e Diretor Acadêmico da Faculdade Metropolitana da Grande Recife. E-mail: arandi.campelo@globo.com

2 Estudante do curso de Administração da Faculdade Metropolitana da Grande Recife.

E-mail: carolinaqueiroz539@gmail.com

3 Estudante do curso de Administração da Faculdade Metropolitana da Grande Recife.

E-mail: debyandrezza@hotmail.com/dandrezza185@gmail.com

4 Estudante do curso de Administração da Faculdade Metropolitana da Grande Recife.

E-mail: natislamer@gmail.com

${ }^{5}$ Coorientador. Professor da Faculdade Metropolitana da Grande Recife.

E-mail: proferon100@gmail.com 


\begin{abstract}
The present study addresses verbal and non-verbal communication within the institutional environment. It was built through bibliographic research and data collection with a population composed of workers from thirty administrative sectors, totaling ninety-three employees, held at the Metropolitan Faculty of Greater Recife from August to November 2020. Its main objective is to analyze verbal communication and non-verbal within the corporate environment. The theoretical references presented for scientific support were, mainly, Biderman (2009) and Cardoso (2006). Of the entire sample body, only nineteen employees agreed to participate in the survey. To evaluate the analyzed criteria, a qualitative questionnaire was applied, using the Googleforms platform. The questionnaire data elucidated possible fear on the part of the employees during the conduct of the research, which may have generated divergences in the answers, corroborating with what was addressed in all the content, in which the absence or the poor formulation of the reply of one of the communication parts reduce satisfaction and evolution of processes within the company.
\end{abstract}

Keywords: Business communication. Culture and organizational climate. Verbal language. Body language. Communication noise.

\title{
INTRODUÇÃO
}

Este artigo aborda o tema da comunicação verbal e não verbal e os fatores que influenciam as relações entre líderes e liderados, focando no estudo de caso do setor administrativo da Faculdade Metropolitana da Grande Recife. O artigo está estruturado com os tipos de comunicação dentro das organizações, além das influências da cultura no clima organizacional e comunicação interpessoal nas organizações, abordando os subitens comunicação verbal, comunicação não verbal e linguagem corporal como ferramenta de trabalho.

O tema escolhido importa como uma ferramenta básica para o desenvolvimento coletivo e individual no meio laboral sobre como se portar ou como transmitir a correta mensagem daquilo que se quer dizer para que a comunicação seja efetuada de maneira clara, objetiva e sem ruídos. Contemplando o campo investigativo, o instrumento utilizado na pesquisa foi um questionário semiaberto.

$\mathrm{Na}$ pesquisa constam indagações sobre como a liderança lida com este assunto e sobre como os liderados e colaboradores sentem-se ao serem abordados de maneira positiva ou negativa no seu cotidiano. São fornecidas informações sobre a forma de desempenho que a equipe tem e os tipos de estímulos que poderão receber para que venham a desenvolver suas atividades com maior eficiência. 


\section{REFERENCIAL TEÓRICO}

Há uma grande necessidade hoje, no mundo empresarial, de que um colaborador tenha, junto as suas qualidades profissionais, o poder de ser um bom comunicador e de transmitir informações corretamente durante entrevistas de emprego, conversas formais, reuniões de negócios e, até mesmo, durante conversas informais. Com isso, o referencial trata da maneira eficaz a necessidade de entender e ser entendido na comunicação entre líderes e liderados.

\section{A comunicação dentro das organizações}

Dada a importância da comunicação nos demais ambientes de trabalho, é crucial que se perscrute sua utilização e efeitos nas corporações. Portanto, sabendo dos recursos exigidos para uma comunicação eficaz e dinâmica, assim como seu impacto para a aprendizagem e transmissão de informações na empresa, foram discorridos os assuntos demandados.

Desta forma, a linguagem verbal e não verbal e, também, as relações interpessoais e culturais foram alguns dos tópicos que serviram de base para o desenvolvimento da pesquisa de campo.

\section{Comunicação Verbal}

Na visão de Cruz (2016), mestra em liderança, o processo da comunicação diante das organizações é essencial para demonstrar conhecimento, entendimento e avaliações de uma maneira concreta e objetiva.

Assim, "a comunicação é essencial para todos, pois é através dela que o conhecimento pode ser adquirido e repassado. Podemos ter o livre acesso à expressão, oportunidade de amadurecer, de aprender, ensinar, desenvolver [...]” (CRUZ, 2016, p. 1)

O fundamento das divergências dentro da cultura organizacional se refere aos erros de comunicação, sendo observada através do emissor e receptor.

a) Emissor: indivíduo que transmite a mensagem.

b) Receptor: instrumento com finalidade de decodificar a mensagem ou o indivíduo que recebe a mensagem.

c) Linguagem: uso da escrita ou da fala como meio de comunicação.

d) Mensagem: junção de informações que podem ser divulgadas.

Uma comunicação eficiente nas instituições constitui uma ligação de todos estes sentidos, sendo desejada que aconteça efetivamente de forma eficaz. Saber se comunicar de uma maneira específica é necessário para expandir processos, atingir metas e desenvolver 
maior produtividade. A prática acaba sendo essencial para o aprimoramento das habilidades comunicativas, tais como a obtenção de uma oratória adequada.

Conforme cita Cardoso (2006):

Cada vez mais, tornam-se claro como os processos de comunicação contribuem para desenvolver formas de inter-relação mais participativas e, portanto, mais comprometidas, dando maior flexibilidade às organizações como base de sua permanente transformação e facilitando sua interação social de modo responsável para conjugar seus interesses com as condições culturais, econômicas e políticas nas quais se movem. (CARDOSO, 2006, p. 1132).

A comunicação formal utilizada dentro das organizações visa manter aquilo que é mais vantajoso para ela própria, deixando claro quais são os canais internos e externos que ela pretende usar e qual mensagem deve ser enviada e recebida pelos canais, pontualmente definida pela instituição, de acordo com o planejamento da empresa. A comunicação informal são relações sociais que acontecem livremente entre as pessoas e a empresa de maneira independente da formal.

Para Marinho (2004), a comunicação informal desenvolve melhor a ligação entre os funcionários, evoluindo na execução do trabalho e também constituindo convívio social aos profissionais. Com isso, motiva os trabalhadores a buscar resultados e trazer feedback positivo com o intuito de contribuir com a empresa, destacando o "gatekeeper tecnológico",6.

\section{Comunicação não verbal}

Este tipo de comunicação dá-se pelo uso de vários modelos de expressões, expressões que são chamadas muitas vezes de linguagem corporal, e delas se recebem informações através de comportamentos que devem ser claramente entendidos tanto por quem emite a informação quanto por quem recebe a informação. Segundo Coachingsb (2018):

\footnotetext{
A linguagem corporal está relacionada à comunicação não verbal. Ela aparece na nossa postura, nos gestos, no quão próximo estamos de outra pessoa ao conversar com ela, nas expressões faciais e até no movimento que nossos olhos fazem. É através da linguagem corporal, muitas vezes, que podemos identificar o real significado de uma mensagem ou transmiti-la da maneira que não gostaríamos. (COACHINGSB, 2018, p. 1).
}

Conforme Biderman (2009), as palavras representam em média apenas 7\% do processo de comunicação, o tom de voz $38 \%$, e os sinais não verbais $55 \%$. Olhando para esses dados

6 Gatekeeper tecnológico: conceito mais utilizado na literatura para determinar aqueles que, na empresa, controlam o fluxo de informação entre os membros da organização e fazem circular as mensagens, entrando em contato com outros grupos. 
percebe-se o quão é importante agir bem diante do olhar de quem nos observa e percebemos também que nosso comportamento é tão importante quanto nossas palavras.

E é pensando na importância da comunicação não verbal que muitas organizações adotam modelos de gestão que facilitam o entendimento, dando uma clareza visual de como, quando e onde o processo se desenvolve, usando cores, formas e elementos gráficos como fluxogramas.

Como cita Petenate (2018), os processos de melhoria contínua, controle e planejamento necessitam da gestão visual, apresentando diferentes tipos de aplicações que se enquadram em diferentes situações para a compreensão da situação atual, sendo sistemas que não precisam de muitos recursos, porém são práticos e de fácil entendimento.

\section{Linguagem corporal como ferramenta de trabalho}

Existem situações em que somos induzidos mais pelo que vemos e sentimos do que pelo que ouvimos. Por isso a influência que as mensagens não verbais exercem sobre alguém tem muito mais peso do que apenas o que essa pessoa diz. Tratando-se de linguagem corporal é possível perceber traços de diferentes tipos de personalidades, o que nos leva a descrever um pouco sobre a ligação que existe entre a liderança e a linguagem corporal dentro do trabalho.

Na opinião de Rector e Trinta (2003, p. 5), “o corpo humano pode servir à comunicação interindividual. Quando isto ocorre somos o emissor, que transmite para o outro, o receptor, uma mensagem, consciente ou inconsciente, controladamente ou não." Por isso um líder deve estar atento na mensagem que ele passa para seus liderados, tendo em mente que os resultados das mensagens que são enviadas de forma correta apresentam bons retornos e a utilização do nosso corpo em nosso favor certamente acarretarão em ganhos. Exemplificando um gesto simples como a cabeça erguida, que nos mostra mais confiantes e confortáveis com o que há a nossa volta. Por outro lado existem movimentos e sinais que se devem evitar como cabeça baixa, corpo encolhido e olhar para baixo, pois eles demonstram fraqueza e fragilidade. Sobre esta temática Camargo (2018) afirma que:

\footnotetext{
o objetivo é mostrar e ensinar de modo direto e simples como a linguagem corporal pode ampliar a nossa capacidade de liderança. Pequenos gestos, posturas, movimentos de mãos e de cabeça são capazes de potencializar a liderança de qualquer pessoa. (CAMARGO, 2018, p. 12).
}

Como líderes, muitas vezes, cabe a nós recrutar e selecionar pessoas ou até mesmo outros líderes, então temos que perceber que é possível reconhecer um líder nato por sua 
linguagem corporal, mas também é possível treinar pessoas para que elas saibam utilizar os sinais corretos que favorecem a impressão que é necessária passar para assumir este posto.

Conforme Camargo (2018):

Aqui adentramos um campo interessante: se você trabalha com recrutamento e seleção de pessoal, essas informações simples podem ajudá-lo a avaliar se determinados indivíduos são adequados para cargos de liderança. Antes mesmo da dinâmica de grupo, a postura dos candidatos, sua movimentação corporal, a posição do queixo e das mãos, a maneira como carregam seus pertences, o timbre e o volume da voz dão ao recrutador pistas importantes sobre cada um dos postulantes. (CAMARGO, 2018, p. 14).

\section{As influências da cultura no clima o rganizacional}

A cultura organizacional é um conjunto de hábitos e crenças estabelecidos por normas, valores, atitudes e expectativas compartilhadas por todos os membros da organização, mudando constantemente de acordo com a necessidade de mudança e desenvolvimento interno de um grupo, o que repercute diretamente no clima organizacional, sendo este, representado pelo ambiente psicológico e social da organização, resultando em emoções e graus de satisfação, gerando desejos e expectativas que tendem a aumentar ou diminuir o entusiasmo e a produtividade dos colaboradores. (LÓPEZ, 2016; SILVA et al, 2020; SOUZA et al, 2020).

Nesse sentido, "os estudos culturais permitiram a compreensão da organização como um sistema de signific ado compartilhado, capaz de aprender, mudar e evoluir ao longo do tempo, por meio da interação entre seus membros e entre si mesma e o seu ambiente." (GUIMARÃES; SQUIRRA, 2007, p. 51).

A cultura é a identidade de uma empresa e ao ser empregado no dia a dia do ambiente empresarial torna-se um importante meio de comunicação, gerando trocas de pensamentos e opiniões, trazendo a capacidade de lidar com antecipação e tranquilidade diante das mudanças. Como diz Marchiori (2006):

A cultura e a comunicação organizacional vêm chamando a atenção dos profissionais uma vez que está se tornando um tema fundamental e inquestionável nas empresas. Isso porque atuam nas raízes de uma organização e posicionam a área de comunicação de uma forma estratégica. (MARCHIORI, 2006, p. 26).

Nesse segmento, tornou-se fundamental a função de relações públicas, pois é vista como a principal ferramenta de gerenciamento e de grande importância nas organizações, a qual está diretamente ligada ao relacionamento entre a empresa e seus stakeholders ${ }^{7}$. (MARCHIORI, 2006).

7 Stakeholders: público estratégico que descreve uma pessoa ou grupo que tem interesse em uma empresa, negócio ou indústria, podendo ou não ter feito um investimento neles. 
A Comunicação é um meio de grande importância e é fundamental para que as organizações se comuniquem e interajam diariamente, com o intuito de estabelecer uma boa relação, ambiente agradável e alinhamento de ideias entre as equipes e setores. É necessário que a comunicação seja transmitida da melhor forma possível, sendo de forma clara e objetiva para o melhor entendimento de todos.

Quando em uma organização a comunicação flui de maneira eficaz o clima organizacional torna-se mais leve, as pessoas tendem a se comunicar melhor e consequentemente ocorre um avanço de produtividade dos funcionários, os feedbacks são positivos e por consequência, acabam influenciando de forma direta na motivação, satisfação e criatividade dos colaboradores.

Da mesma forma, quando numa determinada organização a comunicação não ocorre da maneira correta, são causados ruídos que afetam o clima organizacional e, por consequência, o ambiente torna-se pesado, gerando desconforto, desinteresse nas obrigações e conflitos interpessoais. “[...] Pode-se dizer que o clima é bom quando há um nível baixo de rotatividade funcional, com isso um alto tempo de permanência dos colaboradores na organização, também quando eles sentem orgulho em participar da empresa.” (OLIVEIRA, et al, 2014, p. 56).

Cabe ao líder, por meio de diálogos, influenciar e ser o exemplo a ser seguido, conquistando sua equipe com o intuito de manter uma boa relação. Confiança é importante neste processo, pois com a ausência dela torna-se difícil a convivência e o relacionamento entre seus líderes e liderados. O bom líder consegue facilmente a confiança de sua equipe, sabe ser motivador e trabalhar o potencial das pessoas. Conforme descreve Oliveira (2014):

\begin{abstract}
A boa comunicação é essencial para a eficácia de qualquer organização ou grupo. Pesquisas indicam que as falhas de comunicação são as fontes mais frequentemente citadas de conflitos interpessoais. Uma das principais forças que podem impedir o bom desempenho de um grupo é a falta de comunicação eficaz. A comunicação precisa ser transparente e compreensível. (OLIVEIRA et al, 2014, p. 31).
\end{abstract}

\title{
Comunicação interpessoal nas organizações
}

Conforme supracitado, a comunicação é essencial para demonstrar progressos. Em meio à comunicação interpessoal nas organizações, o crescimento profissional é auxiliado, trazendo vantagem em relação à carreira do empregado e, também, ao avanço da corporação. Assim, é fundamental que os empregados melhorem sua comunicação interpessoal no ambiente de trabalho, repassando informações cujas contribuições irão direcionar a organização no meio da conjunção de uma equipe profissional. A esse respeito Adler \& Towne (2002) dizem que: 
o número de pessoas envolvidas. Quando a qualidade da interação é o critério, o oposto da comunicação impessoal é a interação pessoal, e não a comunicação de grupo, pública ou de massa. (ADLER; TOWNE, 2002, p. 10).

A oralidade influencia as pessoas ao se comunicarem regularmente, com o intuito de produzir e planejar discursos, colaborando com o ambiente organizacional da empresa. Possibilita que as sugestões concebidas pelos membros da empresa tornem-se informações assertivas, em lugar de transmitir entraves ou bloqueios que interfiram na acessibilidade e estabelecimento da comunicação. Portanto, dada tal importância, a oralidade remete aos conceitos relativos à associação e comunicação interpessoal, desenvolvendo troca de informações e cooperação coletiva mediante as resoluções necessárias às organizações.

Assim, conforme expressa Moreira (2012):

\begin{abstract}
Passa-se a exigir algo a mais desse super profissional: a competência humana. Habilidades de relacionamento interpessoal tornam-se um diferencial que as empresas buscam em seus colaboradores. Exemplo disso é o comportamento assertivo, uma habilidade cada vez mais valorizada, pois gera, nas organizações, um ambiente em que a comunicação flui de maneira clara e dinâmica. Os problemas são vistos como parte do cotidiano, enfrentados com maturidade e efetivamente resolvidos. (MOREIRA, 2012, p. 113).
\end{abstract}

\title{
METODOLOGIA
}

O objeto geral de estudo deste artigo é a comunicação verbal e não verbal, permitindo, desta forma, verificar o grau de importância que existe na presença e na ausência da mesma no ambiente corporativo. Como objetivos específicos visam-se:

a) Identificar como lideres desenvolvem técnicas mais eficientes no sentido de elaborar um planejamento que facilite o diálogo entre líderes e liderados;

b) Fundamentar a acessibilidade da interpretação na comunicação dentro da equipe de trabalho;

c) Propor estratégias eficazes para um melhor empenho da equipe, intensificando os relacionamentos laborais e proporcionando um melhor clima ao ambiente organizacional.

A escolha do método bibliográfico e da pesquisa de campo teve a finalidade aplicada, com análise propositiva e abordagem centrada nos aspectos qualitativos. Quanto ao instrumento da pesquisa foi elaborado um questionário de caráter semiaberto. 


\section{DESENVOLVIMENTO DA PESQUISA DE CAMPO}

Esta pesquisa de campo foi realizada na Faculdade Metropolitana da Grande Recife ${ }^{8}$, localizada na cidade de Jaboatão dos Guararapes, estado de Pernambuco.

O universo investigado foi o setor administrativo da faculdade, perfazendo um total de noventa e três funcionários. A amostra contou com a participação de dezenove pessoas.

A comunicação com seus superiores é de fácil acesso?

19 respostas

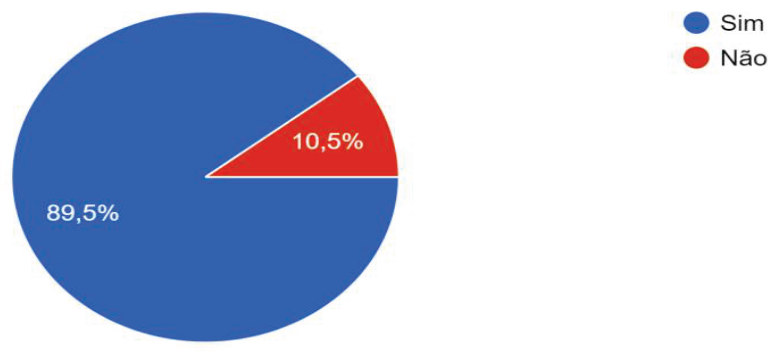

A maioria dos inquiridos apontou que tem uma comunicação de fácil acesso com os superiores. Apenas 10,5\% disseram que não.

Como você se sente em relação à comunicação interna da empresa?

19 respostas

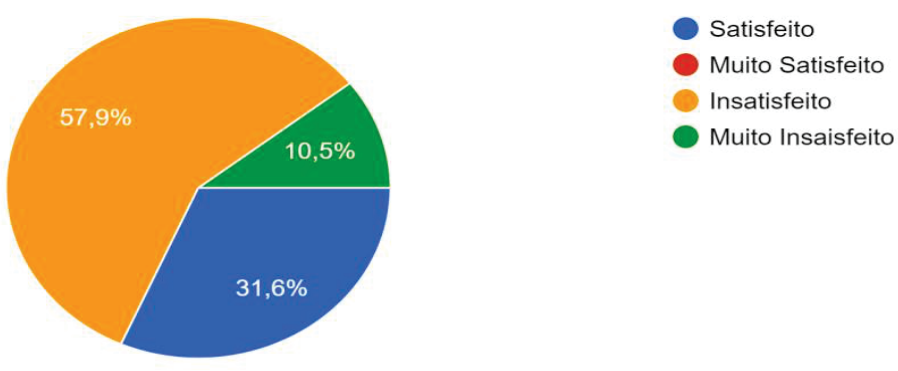

Apesar da maioria das respostas terem sido "sim" na questão anterior, o grau de insatisfação é maior que o de satisfação, conforme 57,9\% dos entrevistados.

8 Faculdade Metropolitana da Grande Recife. Instituição particular, localizada em Jaboatão dos Guararapes, Pernambuco, fundada em 2001, mantida pela União das Escolas Superiores de Jaboatão (UNESJ). 
Você possui uma relação de fácil comunicação com sua equipe de trabalho?

19 respostas

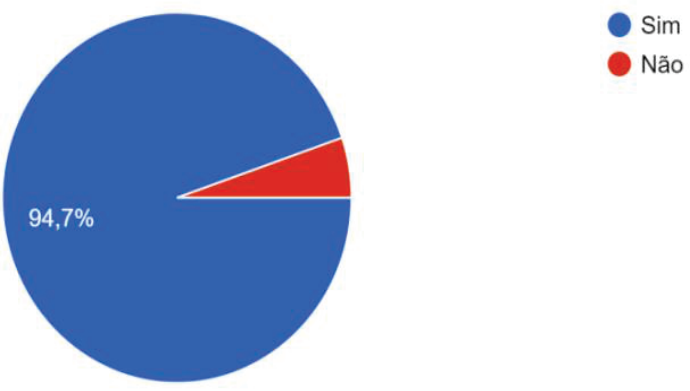

97,7\% dos inquiridos revelaram que eles têm uma relação de fácil comunicação com sua equipe.

Quais os meios de comunicação são utilizados na sua empresa?

19 respostas

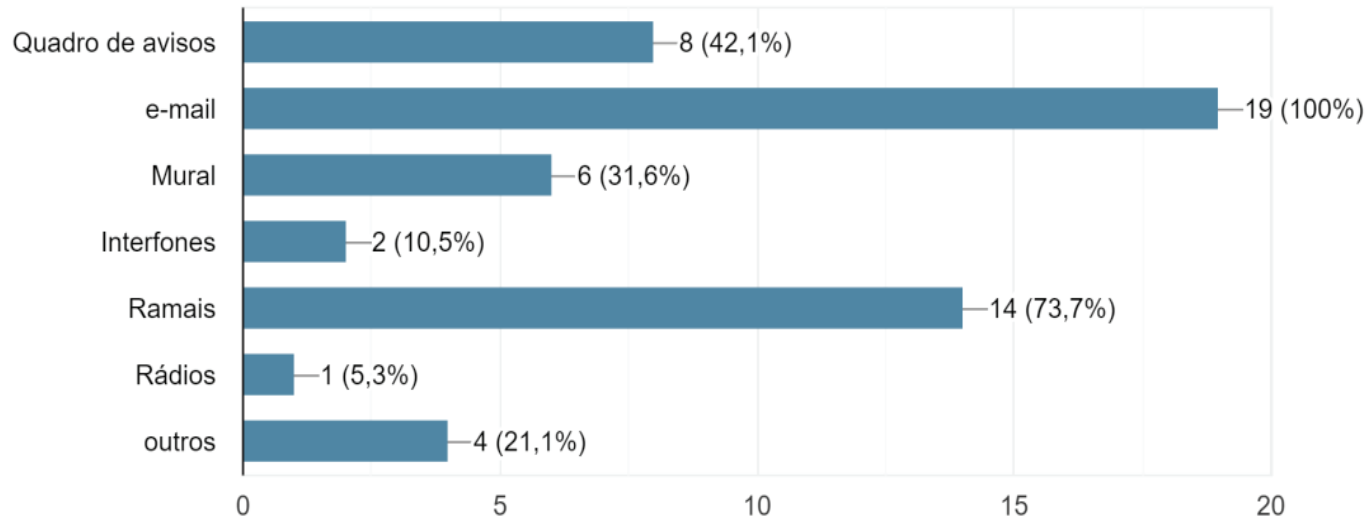

Apesar de afirmar que são usados vários meios de comunicação, os inquiridos confirmaram que o e-mail é o meio de comunicação mais usado na instituição como total de $100 \%$, seguido pelos ramais com o total de $73 \%$.

Descreva abaixo qual ou quais meios de comunicação são usados frequentemente para interação com a liderança: 19 respostas

"E-mails, WhatsApp e comunicação pessoal"

"Reuniões"

"Pessoalmente, por WhatsApp ou e-mail" 
Dentre todas as respostas merecem destaque as respostas acima, pois elas revelam a interação das relações de forma pessoal com a liderança.

\section{Descreva abaixo qual ou quais meios de comunicação são usados frequentemente para interação com a equipe de trabalho: 19 respostas \\ "Reuniões, saídas em grupo, brainstorming."}

Com base neste questionamento merece destaque a resposta acima, que revelou uma técnica usada em grupo, "brainstorming", contribuindo para a ideia de Marinho (2004), que diz que a comunicação informal desenvolve melhor a ligação entre os funcionários, evoluindo na execução do trabalho e também constituindo convívio social aos profissionais.

\section{A instituição ouve seus colaboradores e dá retorno?}

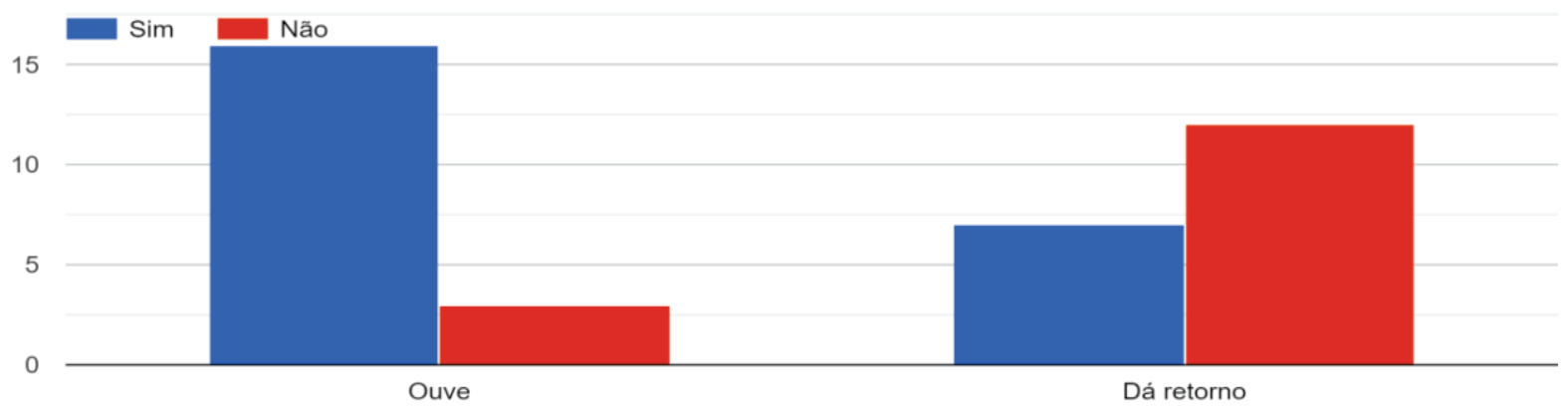

A maioria dos entrevistados revelou que a instituição ouve os seus colaboradores, mas em contrapartida a maioria revelou que não dá retorno, deixando clara a disparidade que existe entre ouvir e dar retorno.

9 Brainstorming: técnica definida pela apresentação espontânea de pensamentos e ideias, tendo como propósito solucionar alguma questão, problema, ou produzir algo criativo. 
Assinale abaixo numa escala de 0 a 10 o seu nivel de satisfação em relação à comunicação ao ambiente de trabalho?

19 respostas
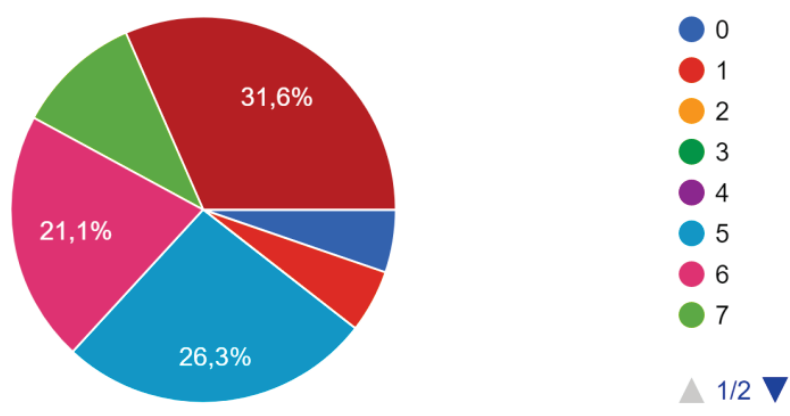

Numa escala crescente de zero a dez a maioria dos inquiridos selecionaram diferentes níveis de satisfação em relação à comunicação, somando 31,6\% para o nível 1, 26,3\% para o nível 5, e 21,1\% para o nível 6 de satisfação.

Com que frequência seu lider o ouve e presta atenção no que fala?

19 respostas

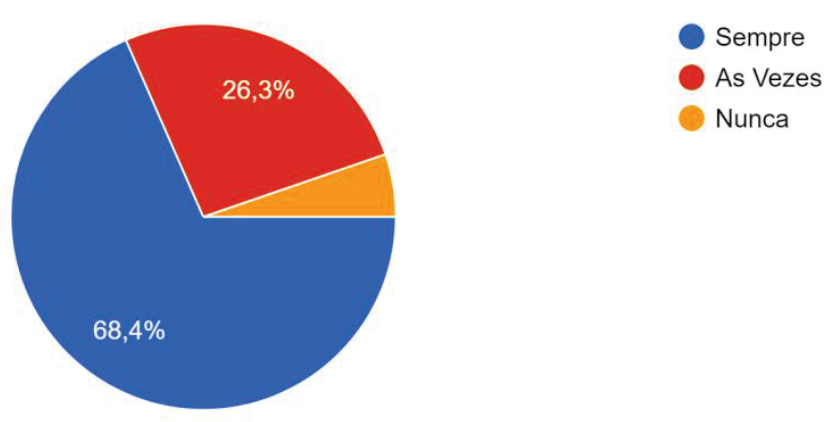

Com $68,4 \%$ a maioria dos inquiridos revelou que sempre a liderança presta atenção no que eles falam.

Com que frequência acontecem reuniões internas no seu setor de trabalho: 19 respostas

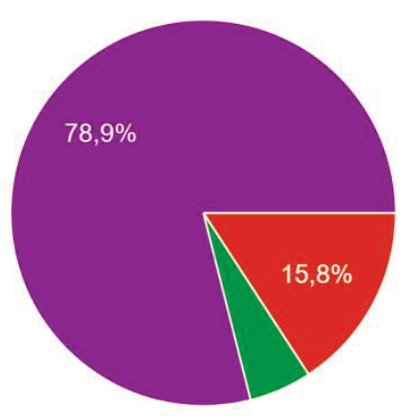

Diária

Semanal

Quinzenal

Mensal

As reuniões tem datas esporádicas 
Segundo os entrevistados o tipo de reunião que mais acontece são as esporádicas.

\section{CONSIDERAÇÕES FINAIS}

Este artigo foi desenvolvido através de pesquisa na Faculdade Metropolitana da Grande Recife, em Jaboatão dos Guararapes. O objeto de estudo foi verificar a importância da comunicação verbal e não verbal efetiva no ambiente de trabalho. $\mathrm{O}$ objetivo geral desse artigo foi atingido, visto que houve a análise, dentro do ambiente laboral, da comunicação verbal e não verbal utilizadas. Entre os objetivos específicos não houve diferentes resultados, de maneira que a pesquisa efetuada possibilitou a compreensão de como líderes dialogam com liderados e como acontece o diálogo entre os integrantes da empresa. Assim, foi permitido o mapeamento e proposição de estratégias para aprimorar a dinamicidade da comunicação laboral. A pesquisa consistiu no uso do método bibliográfico e pesquisa de campo, com abordagem de aspecto qualitativo. Diante do exposto pode-se elucidar que, embora a comunicação ocorra entre os setores, existem fatores que mostram algumas divergências nas respostas da presente pesquisa, relacionados ao feedback e à satisfação dos colaboradores no ambiente corporativo, tendo em vista que há o recebimento da mensagem e ao mesmo tempo existe insatisfação sobre a réplica da mesma, o que corrobora com a presente pesquisa, levando em consideração que a ausência ou a má formulação da réplica de uma das partes da comunicação reduz a satisfação e a evolução dos processos dentro da empresa. Recomenda-se a busca pelo investimento na divulgação da comunicação interna, visando promover treinamentos e programas de interação entre líderes e liderados para que haja uma melhor conexão entre os mesmos e assim seja eliminado o receio que existe ao expor sugestões, críticas e elogios que foram perceptíveis durante a pesquisa.

\section{REFERÊNCIAS}

ADLER, Ronald B.; TOWNE, Neil. Comunicação interpessoal. 9. ed. Rio de Janeiro: LTC, 1999.

BIDERMAN, Albert. Nonverbal Communication. 3. ed. Piscataway, New Jersey: Aldine Transaction, 2009.

CAMARGO, Paulo Sérgio de. Liderança e linguagem corporal: técnicas para identificar e aperfeiçoar líderes. São Paulo: Summus Editorial, 2018.

CARDOSO, Onésimo de Oliveira. Comunicação empresarial versus comunicação organizacional: novos desafios teóricos. 2006. Rev. Adm. Pública. Vol. 40, n.6, pp.1123- 
1144. ISSN 1982-3134. https://doi.org/10.1590/S0034-76122006000600010. Disponível em: https:/www.scielo.br/scielo.php?pid=S003476122006000600010\&script=sci_abstract\&tlng= pt. Acesso em: 1 abr. 2020.

CRUZ, O Papel Estratégico da Comunicação nas Organizações. 2016. Disponível em: https://administradores.com.br/artigos/o-papel-estrategico-da-comunicacao-nas-organizacoes Acesso em: 1 abr. 2020.

DICIO. Dicionário online de português. Brainstorming. Dicio. 2009. Disponível em: https://www.dicio.com.br/brainstorming/. Acesso em: 26 nov. 2020.

LÓPEZ, L.; MARCELA, L. Cultura organizacional: entre el individualismo y el colectivismo. Colombia: Editorial Sello Editorial, Universidad del Tolima, 2016.

GUIMARÃES, A. S.; SQUIRRA, S. C. de M. Comunicação organizacional e o processo comunicacional: uma perspectiva dialógica. Revista FAMECOS. 2007, n ${ }^{\circ} 33$. Disponível em: https://revistaseletronicas.pucrs.br/ojs/index.php/revistafamecos/article/view/3433/2695

Acesso em: 02 abr. 2020.

MARCHIORI, Marlene. Cultura e Comunicação Organizacional: um olhar estratégico sobre a organização. 2. ed. São Caetano, São Paulo: Difusão, 2006.

MARINHO, Sandra. Comunicação Informal nas Organizações: um estudo de caso em I\&D. Portugal, 2004. Disponível em: https://repositorium.sdum.uminho.pt/bitstream/1822/2728/1/smarinho_VIIALAIC_2004.pdf Acesso em: 02 abr. 2020.

MOREIRA, Elen Gongora. Clima organizacional. Curitiba: IESDE Brasil S.A, 2012.

OLIVEIRA, Elisete et al. Cultura Organizacional. Londrina: Educacional S.A, 2014.

PETENATE, Marcelo. Gestão Visual. Escola EDTI. 25 de Mar. 2018. Disponível em: https://www.escolaedti.com.br/gestao-visual. Acesso em: 03 abr. 2020.

RECTOR, M.; RAMOS TRINTA, A. Comunicação do corpo. São Paulo: Ática, 2003.

SBCOACHING. Linguagem corporal: o que é, diferentes tipos e importância. 2018. Disponível em: https://www.sbcoaching.com.br/blog/linguagem-corporal/. Acesso em: 03 abr. 2020.

SOUZA, I. M.; BACHTOLD, C. A. Cultura organizacional e sua influência no desempenho e motivação no trabalho do servidor público: estudo de caso na prefeitura de Colombo-PR. Revista Mundi Engenharia, Tecnologia e Gestão. v.5, n.4, 2020.

SILVA SOBRINHO, P .; MONTEIRO, M. S. Administração Participativa e sua Influência no Clima Organizacional: Uma Pesquisa Bibliográfica. Revista de ciências sociais aplicada. v.1, n.1, 2020. 


\section{APÊNDICE A - Modelo do questionário da pesquisa de campo}

Este questionário tem por finalidade analisar a comunicação verbal e não verbal dentro do ambiente corporativo.

1) A comunicação com seus superiores é de fácil acesso?
( )SIM
( ) NÃO

2) Como você se sente em relação à comunicação interna da empresa?
( )SATISFEITO
( )MUITO SATISFEITO
( )INSATISFEITO
( )MUITO INSATISFEITO

3) Você possui uma relação de fácil comunicação com sua equipe de trabalho?
( )SIM
( ) NÃO

4) Quais os meios de comunicação são utilizados na sua empresa?
a) ( )Quadro de avisos
b) ( )e-mail
c) ( ) mural
d) ( )interfones
e) ( )ramais
f) ( )rádios
h) Outros:

5) Descreva abaixo qual ou quais meios de comunicação são usados frequentemente para interação com a liderança:

6) Descreva abaixo qual ou quais meios de comunicação são usados frequentemente para interação com a equipe de trabalho:

7) A instituição ouve seus colaboradores e dá retorno?

$\begin{array}{lcc} & \text { Sim } & \text { Não } \\ \text { OUVE } & (\text { ) } & (\text { ) } \\ \text { DÁ RETORNO } & (\text { ) } & (\text { ) }\end{array}$

8) Assinale abaixo numa escala de 0 a 10 o seu nível de satisfação em relação à comunicação ao ambiente de trabalho?

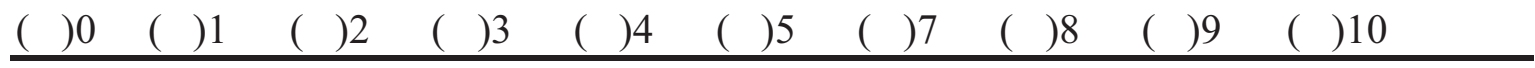

9) Com que frequência seu líder o ouve e presta atenção no que fala?
( ) Sempre
( ) Às vezes
( ) Nunca 
10) Com que frequência acontecem reuniões internas no seu setor de trabalho?
( ) Diária - ( ) Semanal - ( ) Quinzenal - ( )Mensal
( ) As reuniões têm datas esporádicas. 


\title{
CONCILIAÇÃO: INSTRUMENTO DE CELERIDADE E EQUILÍBRIO PROCESSUAL NA JUSTIÇA DO TRABALHO
}

\author{
https://dx.doi.org/10.48097/2674-8673.2021n5p03
}

\author{
Jonathas Ferreira da Silva Lopes ${ }^{1}$ \\ Severina Francisca Roberto da Silva ${ }^{2}$ \\ Carlos Augusto da Silva Cavalcanti ${ }^{3}$
}

\section{RESUMO}

O presente artigo foi elaborado, através de pesquisa bibliográfica, com a finalidade de elucidar o tema sobre a conciliação como uma ferramenta capaz de atuar na celeridade e equilíbrio processual na Justiça do Trabalho, tendo em vista os desdobramentos do referido tema, objetivando uma resposta legal, fundada nas Consolidações das Leis Trabalhistas de 2017 e demais autores que dispunham sobre o referido assunto. Este trabalho mostra a eficiência, eficácia e viabilidade dos instrumentos da mediação e conciliação nas relações jurídicas, a fim de solucionar o litígio na Justiça do Trabalho.

Palavras-chave: Conciliação. Mediação. Conflitos trabalhistas. Processo trabalhista.

Data de submissão: 12/02/2021

Data de aprovação: 31/03/2021

\begin{abstract}
The present article was elaborated, through bibliographic research, with the purpose of elucidating the theme about the conciliation as a tool capable of acting in the speed and procedural balance in the Labor Justice, considering the unfolding of the referred theme, aiming at a legal answer, founded on the Consolidations of the Labor Laws of 2017 and other authors who provided on the referred subject. This work shows the efficiency, effectiveness and viability of the instruments of mediation and conciliation in legal relations, in order to resolve the dispute in the Labor Court.
\end{abstract}

Keywords: Conciliation. Mediation. Labor conflicts. Labor process.

\footnotetext{
${ }^{1}$ Discente do Curso de Bacharelado em Direito da Faculdade Metropolitana da Grande Recife.

E-mail: jonathasferreira34@gmail.com

2 Discente do Curso de Bacharelado em Direito da Faculdade Metropolitana da Grande Recife.

E-mail: ninhalima21@hotmail.com

${ }^{3}$ Orientador / Docente do Curso de Bacharelado em Direito da Faculdade Metropolitana da Grande Recife.

E-mail: carloscavalcanti@metropolitan.edu.br
} 


\section{INTRODUÇÃO}

O tema em tela reveste-se de esplêndida importância para a sociedade, vez que aprimora o relacionamento das partes que litigam na Justiça do Trabalho com a finalidade de produzir, sem delongas, uma decisão justa, célere e eficaz.

Não há dúvida de que a ferramenta digital é um sinal de mudança e aperfeiçoamento na estrutura do Poder Judiciário. Sua razão de ser influenciou não só o mundo, mas também a própria seara jurídica que, durante este período de pandemia, vem inovando reiteradamente a Justiça do Trabalho.

Não obstante, durante este período pandêmico, houve significativas mudanças na Justiça do Trabalho que atingiu o arcabouço do Poder Judiciário, razão pela qual a ferramenta digital implicou na reorganização do ideal jurídico e levou os juristas a um senso mais crítico e célere, a fim de manter o exercício jurisdicional.

Tanto é que, hoje, as audiências estão sendo realizadas na modalidade telepresencial, notadamente por videoconferência, garantindo soluções equilibradas e segurança jurídica, revelando o mundo virtual como instrumento fundamental para a pacificação nas relações trabalhistas.

O princípio da conciliação é um método, obrigatório, legal, de solução consensual de conflitos, conforme o artigo $3^{\circ}, \S 3$ do Código de Processo Civil.

A conciliação é caracterizada pelas permissões mútuas, ou seja, quando ambas as partes abrem mão, de parte, de sua pretensão, com o propósito de resolver o conflito de forma mais rápida, aceitando um pouco menos do valor que tem direito.

Segundo o pensamento de Eduardo Gabriel Saad (2000), “conciliação é o ato pelo qual o juiz oferece ao reclamante e ao reclamado as bases para composição de seus interesses em conflito".

Não obstante, o pensamento de Souza (2016) ratifica que a conciliação é definida “como um processo autocompositivo breve no qual as partes ou os interessados são auxiliados por um terceiro, neutro ao conflito, ou por um painel de pessoas sem interesse na causa, para assistir a ela, por meio de técnicas adequadas, a chegar a uma solução ou a um acordo".

Contudo, este meio alternativo de resolução dos conflitos, chamado conciliação, trouxe vários aspectos positivos, externando-os ao mundo jurídico, tendo em vista o advento das leis 9.957/2000, e 9.958/2000, que deram mais importância à conciliação. (BRASIL, 2000). 


\section{A conciliação como método de solução dos conflitos trabalhistas}

A conciliação tem como método alternativo de obter solução consensual, entre as partes envolvidas, sem precisar recorrer ao judiciário.

É importante a viabilização desses mecanismos que proporcionam aos interessados essa solução de conflitos.

Vale ressaltar que, acerca do que se refere aos meios de soluções de conflitos, dentre eles a mediação, arbitragem e conciliação, podem apresentar mecanismos para a edificação de soluções de litígios, sem precisar ir ao judiciário para o ajuizamento de ações, que tem como fator predominante o alcance da pacificação social.

Segundo Souza (2016), no cenário atual, com base nas políticas públicas, no Conselho Nacional de Justiça, e consolidada nas resoluções e publicações diversas, a conciliação no âmbito do Poder Judiciário visa:

I- $\quad$ além do acordo, uma efetiva harmonização social das partes;

II- $\quad$ restaurar, dentro dos limites possíveis, a relação social das partes;

III- utilizar técnicas persuasivas, mas não impositivas ou coercitivas para se alcançarem soluções;

IV- demorar suficientemente para que os interessados compreendam que o conciliador se importa com o caso e a solução encontrada;

V- humanizar o processo de resolução de disputas;

VI- preservar a intimidade dos interessados sempre que possível;

VII- visar à solução construtiva para o conflito, com enfoque prospectivo para a relação dos envolvidos;

VIII- permitir que as partes sintam-se ouvidas; e

IX- utilizar-se de técnicas multidisciplinares para permitir que se encontrem soluções satisfatórias no menor prazo possível.

Destarte à conciliação das partes, consideram-se recorrente as demandas judiciais e a premente necessidade de solução alternativa na qual possibilite essa redução do número de demandas que afogam o judiciário.

No entanto, busca-se por métodos alternativos e consensual que sejam adequados para por fim aos conflitos, no qual se destaca a conciliação, como meio de solução dos conflitos trabalhistas.

Outrossim, conforme preconiza Schiavi (2016, p. 40), a conciliação judicial trabalhista é o meio de solução do conflito trabalhista, mediante o ingresso de concessões recíprocas. 
Por fim, o conciliador tem como função precípua a intervenção ativa na negociação das partes, à medida que se apresentam eventuais soluções para determinado conflito, razão pela qual a conciliação tem como base a autonomia privada, mesmo no que diz respeito à iniciativa como procedimento de negociação.

\section{Do princípio da indisponibilidade e da conciliação}

Segundo Delgado (2016), o princípio da indisponibilidade nos direitos trabalhistas significa a inviabilidade técnico-jurídica de poder. $\mathrm{O}$ empregado despoja-se por uma manifestação de vontade, das vantagens e proteções que lhes asseguram a ordem jurídica e o contrato.

Nessa vertente, o princípio da indisponibilidade colabora que o empregado não pode renunciar ao direito que lhe confere proteção, por sua simples manifestação de vontade, uma vez que causa o desequilíbrio de ordem econômica, social e cultural entre os sujeitos trabalhistas.

O princípio da indisponibilidade de direitos visa assegurar ao empregado os direitos e garantias de modo que não se admite que ele renuncie, em permuta de supostos benefícios que lhe são oferecidos pelo empregador.

Assim, esse princípio revela característica imprescindível nas normas trabalhistas, sendo, em sua finalidade social, no qual o caráter protetivo reflete o interesse público, vindo a restringir os direitos das partes nas negociações trabalhistas, visando resguardar os direitos do trabalhador.

No momento em que é realizada a conciliação nas ações trabalhistas, tanto o empregado quanto o empregador sentem-se obrigados a renunciarem parte dos seus direitos para vê-los atendidos, no mínimo parcialmente, em virtude da premente necessidade em que se encontram quando recorrem ao judiciário para solução dos litígios.

Por exemplo, nas vezes em que as verbas salariais discutidas em ações trabalhistas têm cunho alimentício, consequentemente, a renúncia aos direitos assegurados pela lei aos trabalhadores configura o então chamado princípio da indisponibilidade de direitos.

No entanto, as ações trabalhistas poderão ser submetidas à conciliação a qualquer tempo processual, no intuito de garantir uma solução pacífica e justa às partes envolvidas na demanda judicial como se denota ao trabalhador parte hipossuficiente da relação trabalhista, conforme preconiza o art. 764, parágrafo $1^{\circ}$, da CLT. 


\section{A conciliação como equilíbrio das partes no processo do trabalho}

Segundo preconiza a CLT, a conciliação torna-se obrigatória em dois momentos processuais: após a abertura da audiência de instrução e julgamento, conforme o artigo 846; e depois de aduzidas as razões finais pelas partes, corroborando com o art. 850, do mesmo diploma legal, sendo certo que a sua omissão pode gerar a nulidade do julgamento.

$\mathrm{Na}$ justiça do trabalho o acordo tem prioridade absoluta. Conforme exposto na lei 9.957/2000, o procedimento sumaríssimo deu importância à conciliação. Ao dispor de aberta a sessão, o juiz esclarecerá às partes ali presentes sobre as principais vantagens da conciliação e usará os meios necessários de persuasão para a solução conciliatória do conflito em qualquer fase da audiência.

Não obstante, na lei 9.958/2000, a conciliação prévia deu o primeiro passo a fim de condicionar a tentativa de conciliação prévia no ajuizamento da ação trabalhista, conforme demonstrado no art. 625-D, em que fica claro sobre qualquer demanda de natureza trabalhista ser submetida à Comissão de Conciliação Prévia, se na localidade da prestação de serviços houver sido instituído a comissão no âmbito da empresa ou do sindicato da categoria.

Essa atitude posta e acordada perante as comissões de conciliação não possui efeito de decisão irrecorrível, razão pela qual sempre acontece com os acordos homologados pela justiça do trabalho.

A conciliação, ao decorrer do litígio trabalhista, ganha eficácia e produz efeitos jurídicos após a efetiva homologação dada pelo magistrado do trabalho.

E se houver fraude na conciliação? Caso exista, o juiz constatará que há hipótese de fraude na conciliação ou acordo manifestamente lesivo, e deverá abster-se de homologar o referido acordo, tendo em vista o exemplo de, nos casos das lides simuladas, em que o patrão estimula seus empregados a ajuizarem ações, com o exposto de celebrar acordos em valores ínfimos àqueles que de fato seriam objeto do acerto rescisório.

Entretanto, depois de obtida a chancela judicial, o acordo ganharia o status de coisa julgada, e que impediria o empregado de reclamar as diferenças devidas, razão pela qual essa situação só seria agravada quando o acordo concluísse pela quitação do objeto do pedido e extinto o contrato de trabalho. Por fim, resultaria na impossibilidade da parte pleitear em juízo qualquer direito trabalhista adquirido no curso do contrato.

No mais, a conciliação trabalhista deve ser incentivada na fase de sua importância antecipatória de prestação jurisdicional, motivo pelo qual a sua homologação, também, tem o 
dever de ser condicionada à análise do juiz, que, no entanto, deverá rejeitar sempre que detectar práticas fraudulentas ou lesivas aos interesses do trabalhador.

\section{Mediação e conciliação na justiça do trabalho durante a pandemia}

É necessário pontuarmos que o art. $3^{\circ}, \S 3^{\circ}$, do CPC/2015, é explícito ao falar sobre a conciliação e a mediação como métodos de solução consensual de conflitos.

Além do mais, o art. 846 da CLT vislumbra a necessidade e obrigatoriedade do juiz, no início da audiência, propor a conciliação. No mesmo sentido, o art. 852-E da CLT elucida que o juiz esclarecerá as partes presentes sobre as vantagens da conciliação e usará os meios adequados de persuasão para a solução conciliatória do litígio.

Caso esta não ocorra, novamente, após as partes aduzirem razões finais, a conciliação voltará a ser proposta antes da decisão judicial. É o que está expresso no art. 850 da CLT.

Ainda sobre o conceito de mediação, Dale (2016) diz que é um dos instrumentos de pacificação de natureza autocompositiva e voluntária, no qual um terceiro, imparcial, atua, de forma ativa ou passiva, como facilitador do processo de retomada do diálogo entre as partes, antes ou depois de instaurado o conflito.

Segundo a publicação de Basílio (2020), no que concerne à mediação e à conciliação durante este período pandêmico, não há como questionar que o novo coronavírus trouxe graves repercussões em todo o cenário atual, em todos os segmentos da sociedade.

Esses reflexos alcançaram, com grande avanço, a esfera jurídica de milhares de brasileiros, de tantos conflitos que surgiram ao longo de todo esse caminho e que vem sendo objeto de decisões judiciais. Como exemplo, podemos fazer menção à questão relativa ao pagamento de aluguéis, descumprimentos contratuais, embates de natureza trabalhista, rescisão de negócios jurídicos, entre outros conflitos gerados pela pandemia.

Assim, podemos observar que há um número expressivo de leis, medidas provisórias e decretos que têm como fator crucial o objeto regular, de maneira específica, nas relações sociais diante desse momento de crise econômica, social e até mesmo de saúde pública, que surgiu nessa conjuntura atual.

Por conseguinte, é possível que, porventura, milhões de demandas jurídicas venham a ser propostas, visto que dizem respeito aos litígios que decorrem da pandemia perante o Poder Judiciário. 
Vale frisar que há uma avalanche de processos judiciais aguardando o período póspandemia o que, provavelmente, será bem maior daquelas decorrentes no passado, de planos econômicos que até o presente momento transitam pelos tribunais.

Além do mais, essa eficiência e agilidade que toda população almeja para a solução dos seus conflitos ou interesses, dificilmente serão rápidos por meio das ações judiciais, tendo em vista que a demanda de tempo é maior.

Posto isto, de forma válida e eficaz, os litigantes possuem instrumentos e meios jurídicos que já vinham se destacando há um tempo no ambiente jurídico brasileiro.

Não obstante, esses instrumentos ou formas alternativas de solução de conflitos, como a conciliação e a mediação, são de baixo custo e de grande rapidez, sendo fáceis de serem realizados por meio digitais como a internet, chamada via WhatsApp, videoconferência, etc. É uma oportunidade de grande valor para a advocacia desempenhar o seu papel constitucional, além de atender às demandas jurídicas durante essa pandemia, sem precisar violar o isolamento social decretado pelos governantes.

Contudo, por meio desses instrumentos de mediação e da conciliação, que visam solucionar as disputas, também serão negociadas soluções para as ações judiciais que já vinham em curso, até mesmo antes da pandemia, portanto, essas inovações, criatividades e flexibilidades obrigaram e levaram a todos, quem quer que seja, a um senso de adaptabilidade.

A mediação e a conciliação, diante do cenário atual pandêmico, alcançaram várias transformações na seara trabalhista. Hoje, o mundo não é mais o mesmo. As versões ultrapassadas estão sendo policiadas através do mundo digital.

Em meio a este período catastrófico, várias medidas foram e estão sendo tomadas, com o propósito de continuar o exercício pleno das atividades jurídicas. Decisões judiciais, sentenças, acordos e homologações estão explicitamente detidos no âmbito do mundo virtual, por intermédio de chamadas de videoconferência.

O instrumento digital abarca ainda mais a relevância dos atos praticados na mediação e conciliação na justiça do trabalho diante da solução de conflitos.

Consoante ao entendimento do juiz federal do trabalho, coordenador da Escola Judicial do TRT do Paraná, mestre em Resolução de Disputas pela Pepperdine University (EUA) e em Direito pela UFPR, Fernando Hoffmann, a questão é promover a mediação e a conciliação de conflitos que tratem sobre a preservação da saúde e da segurança do trabalho em serviços públicos e atividades consideradas essenciais que estão descritas no art. $3^{\circ}$ do decreto $n^{\circ}$. 10.282/2020, que busca privilegiar soluções que não venham a inviabilizar a continuidade. 
$\mathrm{O}$ ato na mediação e conciliação dar-se-á nos conflitos individuais e coletivos em âmbito pré-processual. Evidencia-se que esses conflitos listam-se aos interesses do exercício de atividades laborais e do funcionamento das atividades empresariais, que diz respeito ao contexto da situação excepcional da pandemia.

Uma grande inovação é que a Justiça do Trabalho tradicional exercia as atividades apenas na mediação pré-processual de conflitos coletivos.

Necessário pontuar que sobre os dissídios individuais, a Justiça do Trabalho não considera a mediação pré-processual adequada pelo fato de não possuir lide, isto é, o conflito de interesses entre o empregador e o empregado. Em razão do acordo de interesses, não foi dado aos juízes mediarem em processo que não aborda um conflito.

No mais, a adequada e oportuna recomendação inova a sistemática, desde que contemple os dissídios individuais específicos e que sejam recorrentes na sua atualidade, que decorrem de conflitos entre o empregado e empregador, que envolve a preservação da saúde e da segurança do trabalho em serviços públicos e a continuidade das atividades consideradas essenciais.

Essas diretrizes expostas são excepcionais e voltadas à mediação e à conciliação, por meios eletrônicos e por videoconferência de conflitos individuais e coletivos, anteriormente à fase processual, à proporção que perdurar o período de pandemia.

Não obstante, as recomendações aos juízes do trabalho, em geral, destinam-se para todos os magistrados, plantonistas e, principalmente, aos integrantes dos Núcleos Permanentes de Métodos Consensuais de Solução de Disputas (NUPEMECs-JT) e dos Centros Judiciários de Métodos Consensuais de Solução de Disputas (CEJUSCs-JT), sendo ele de $1^{\circ}$ e $2^{\circ}$ graus.

Contudo, desde que respeitado o livre convencimento e a independência funcional dos juízes, o ato recomenda a realização de esforços, a fim de fazer acontecer a mediação e a conciliação de conflitos que trata sobre a preservação da saúde e posterior segurança do trabalho em serviços públicos. As atividades essenciais deverão ser em busca de soluções que não venham dificultar a continuidade da prestação de serviço, todavia, o ato destaca a necessidade da participação e interação das partes envolvidas no processo.

Vale ressaltar que os magistrados devem sempre atuar com o apoio direto das entidades sindicais, dos advogados e dos membros do Ministério Público do Trabalho.

Além do mais, até a efetiva execução de ferramenta nacional unificada para adotar e adequar à mediação e à conciliação, os magistrados do trabalho devem ficar atentos, especificamente, na utilização de aplicativos ou programas de mensagens e por 
videoconferência de acesso público e gratuito, visto que sejam dotados de funcionalidades de gravação de mídia audiovisual, para assim poder ficar preservado na memória das tratativas e da documentação da homologação dos acordos.

Destarte, o potencial da mediação e conciliação durante e pós-pandemia demonstra ser consenso geral e de caráter importantíssimo e, posteriormente, essa fase ser superada, a parte principal de combate à pandemia, caso possua esforço a fim de transfigurar a conjuntura pandêmica em circunstância favorável, o Poder Judiciário do Trabalho poderá sair melhor que antes da crise.

No entanto, existem conflitos trabalhistas que são negociáveis e mediáveis a cunho privado, no que garante as condições de equilíbrio de poder entre as partes.

Esses conflitos, que são mediáveis, de forma pré-processual ou extraprocessual, judicialmente conciliáveis, entende-se ser necessária a assistência de um terceiro e o magistrado será o mediador.

Em epítome, a conciliação judicial é denominada como uma espécie de mediação a ser conduzida pelos juízes do trabalho, no trâmite do dissídio trabalhista. Portanto, as técnicas de conciliação são mais limitadas ao invés da mediação genérica, e que por vezes, tendo uma solução negociada, somente será atingida após o processo de judicialização. Razão pela qual, nos casos em que não seja possível a negociação, em função do relacionamento entre as partes litigantes, da condição socioeconômica e da natureza do interesse a ser tutelado, (pré) mediáveis e conciliáveis, a Justiça do Trabalho deverá focar os esforços com a finalidade de culminar os conflitos por intermédio de decisão vinculante.

\section{CONSIDERAÇÕES FINAIS}

Em virtude de sua viabilidade e execução na seara jurídica trabalhista e nas demais relações de trabalho, bem como o teor de sua importância no equilíbrio entre as partes que litigam junto à Justiça do Trabalho, intencionando o aperfeiçoamento e/ou a compreensibilidade do diálogo entre o empregado e o empregador, o tema traz consigo um marco precípuo, objetivando o respeito constitucional ao princípio do devido processo legal e a sua eficácia, a fim de vincular à égide a parte mais fraca na relação processual.

Não obstante, durante este período pandêmico, houve significativas mudanças na Justiça do Trabalho que atingiu o arcabouço do Poder Judiciário, motivo este, que a ferramenta digital implicou na reorganização do ideal jurídico, levando a um senso mais crítico e célere, com o intuito de manter o exercício jurisdicional. 
As audiências na Justiça do Trabalho estão sendo realizadas na modalidade telepresencial, notadamente por videoconferência, garantindo soluções equilibradas e a segurança jurídica no decorrer do processo, revelando o mundo virtual como instrumento fundamental para pacificação nas relações trabalhistas.

Todavia, em meio ao cenário de pandemia, que está reestruturando a seara jurídica, seja ela trabalhista ou não, em nível mundial, o instrumento digital ganhou voz, vez, espaço e oportunidade que cada vez soa fortemente, levando à consciência dos legisladores e juristas, um meio e soluções eficazes, com o propósito de inovar o arcabouço do Poder Judiciário nas relações sociais, isto é, os meios digitais revelaram ao mundo jurídico resoluções que já existiam, mas não eram valoradas significativamente da forma que é hodiernamente.

\section{REFERÊNCIAS}

BASÍLIO, Ana Tereza. A mediação e a conciliação em tempos de pandemia. Jornal do Brasil, publicado em 20 de Maio de 2020. Disponível em: https://www.jb.com.br/pais/artigo/2020/05/1023840-a-mediacao-e-a-conciliacao-em-temposde-pandemia.html. Acesso em: 08 dez. 2020.

BRASIL. Lei $\mathrm{n}^{\mathrm{o}}$ 13.467, de 13 de julho de 2017. Reforma Trabalhista. Altera a Consolidação das Leis do Trabalho (CLT), aprovada pelo Decreto-Lei $\mathrm{n}^{\circ} 5.452$, de $1^{\circ}$ de maio de 1943, e as Leis $\mathrm{n}^{\circ}$ 6.019, de 3 de janeiro de 1974, 8.036, de 11 de maio de 1990, e 8.212, de 24 de julho de 1991.

COSTA, Paulo Roberto Sifuentes. A conciliação no processo do trabalho. TRT da $3^{\mathrm{a}}$ Região. http://www.stf.jus.br/arquivo/cms/conciliarConteudoTextual/anexo/A_conciliacao_no_proces so_do_trabalho.pdf. Acesso em: 08 maio 2020.

DALE, Izadora Farias Freitas Azeredo. A mediação: conceito, princípios norteadores e técnicas para sua aplicabilidade. Disponível em: https://jus.com.br/artigos/48697/amediacao-conceito-principios-norteadores-e-tecnicas-para-sua-aplicabilidade\#_ftnref6.

Acesso em: 10 dez. 2020.

DELGADO, Mauricio Godinho. Curso de direito do trabalho. 15. ed. São Paulo: LTr, 2016.

HOFFMANN, Fernando. Mediação e Conciliação na Justiça do Trabalho Durante A Pandemia. Revista Consultor Jurídico, 21 de abril de 2020. Disponível em: https://www.conjur.com.br/2020-abr-21/hoffmann-mediacao-conciliacao-justica-trabalho. Acesso em: 02 out. 2020.

SAAD, Eduardo Gabriel. Comissões de conciliação prévia. São Paulo: LTr, 2000. 
SCHIAVI, Mauro. Manual de direito processual do trabalho. 10 ed. De acordo com o novo CPC. São Paulo: LTr, 2016.

SOUZA, Aiston Henrique et al. Manual de Mediação Judicial. Conselho Nacional de Justiça. 6. ed. Brasília-DF: 2016.

VELOSO, Cynara S. M.; SANTOS, Cássia Cruz; OTONI, Arthur F. B. B.; LIMA, Géssica D. S. Conciliação na justiça do trabalho. Publicado em 07/2018. Disponível em: https://jus.com.br/amp/artigos/67894/1. Acesso em: 08 maio 2020. 


\title{
CULTURA E CLIMA ORGANIZACIONAL: INFLUÊNCIA NA QUALIDADE DE VIDA NO TRABALHO
}

\author{
https://dx.doi.org/10.48097/2674-8673.2021n5p04
}

\author{
Fabiana Jéssica Prado Lins ${ }^{1}$ \\ Jéssica Renata Gomes Santos ${ }^{2}$ \\ João Biron de Oliveira Filho ${ }^{3}$ \\ Eronildo Ferreira do Carmo ${ }^{4}$
}

\section{RESUMO}

O objetivo principal deste estudo foi compreender a influência que a cultura e o clima organizacional das empresas podem ter em relação às doenças ocupacionais de seus colaboradores como, por exemplo, estresse, ansiedade, depressão, síndrome de burnout, entre outras. Buscou-se também compreender quais os principais fatores que na percepção dos colaboradores causam um clima organizacional negativo. A pesquisa foi bibliográfica e de campo. Para coleta dos dados foi utilizado, como principal ferramenta, um questionário fechado. Foi possível comprovar que as empresas que adotam medidas que visam melhorar a qualidade de vida do trabalhador podem ter um índice maior de colaboradores engajados, motivados e produtivos, enquanto as empresas que não investem nessa área consequentemente tendem a um índice elevado de colaboradores doentes por esses fatores.

Palavras-chave: Cultura organizacional. Clima organizacional. Doenças ocupacionais.

Data de submissão: $05 / 05 / 2021$

Data de aprovação: $31 / 05 / 2021$

\begin{abstract}
The main objective of this study was to understand the influence that the culture and organizational climate of companies can have in relation to occupational diseases of their employees, such as, for example, stress, anxiety, depression, burnout syndrome, among others. We also sought to understand what are the main factors that, in the perception of employees, cause a negative organizational climate. The research was bibliographic and field.

\footnotetext{
${ }^{1}$ Concluinte do curso de Pós-graduação em Psicologia Organizacional e do Trabalho - FMGR.

E-mail: fabianapradolins@gmail.com

${ }^{2}$ Concluinte do curso de Pós-graduação em Psicologia Organizacional e do Trabalho - FMGR.

E-mail: jessicarenatasantos@gmail.com

${ }^{3}$ Professor orientador do curso de Pós-graduação em Psicologia Organizacional e do Trabalho - FMGR.

E-mail: joaobiron@metropolitana.edu.br

${ }^{4}$ Professor coorientador do curso de Pós-graduação em Psicologia Organizacional e do Trabalho - FMGR.

E-mail: proferon100@gmail.com
} 
For data collection, a closed questionnaire was used as the main tool. It was possible to prove that companies that adopt tools that aim to improve the quality of life of workers can have a higher rate of engaged, motivated and productive employees, while companies that do not invest in this area consequently tend to a high rate of sick employees due to these factors.

Keywords: Organizational culture. Organizational climate. Occupational diseases.

\section{INTRODUÇÃO}

Analisar e compreender quais são os fatores que causam doenças ocupacionais é algo fundamental para as empresas nos dias atuais, pois a saúde, o bem-estar, a integridade física e mental do colaborador refletem no seu rendimento no trabalho.

O estresse no ambiente corporativo sempre existiu. A diferença é que nos dias de hoje a consciência de seus efeitos são muito maiores e mais complexos. A qualidade de vida no trabalho tem sido cada vez mais discutida após estudos comprovarem os efeitos positivos que um bom clima organizacional gera tanto aos colaboradores quanto às organizações. $\mathrm{O}$ objetivo do presente estudo é apontar os principais fatores relacionados com o estresse nas organizações bem como programas que podem auxiliar na redução dos mesmos.

\section{REFERENCIAL TEÓRICO}

Neste item são abordadas as bases conceituais sobre cultura e clima organizacional, e sua influência na qualidade de vida do trabalhador sobre os aspectos saúde $\mathrm{x}$ doença, bem como exemplos práticos sobre os temas citados, de modo a facilitar a articulação entre referências e realidade de campo.

\section{Cultura organizacional}

O termo cultura organizacional, que também é conhecida como cultura corporativa, é um termo da administração contemporânea usado para se referir ao conjunto de crenças, missão, valores e políticas internas de uma empresa. Para Schein (2009):

Cultura organizacional é um fenômeno dinâmico que nos cerca em todas as horas, sendo constantemente desempenhada e criada por nossas interações com outros e moldada por comportamento de liderança, e um conjunto de estruturas, rotinas, regras e normas que orientam e restringem $\mathrm{o}$ comportamento. (SCHEIN, 2009, p. 01).

Robbins (2012, p. 501) define cultura como "um sistema de valores compartilhado pelos membros de uma organização que a diferencia das demais.” Desse modo, observa-se que para 
os autores a cultura de uma empresa é caracterizada através do comportamento coletivo e social dos funcionários a partir de princípios propostos pela organização em que fazem parte.

Nessa mesma linha de pensamento Siqueira (2012, p. 331) cita que os valores organizacionais são elementos estruturantes, constituindo padrões coletivos que norteiam o trabalho e o cotidiano nas empresas, os quais devem se subordinar aos valores pessoais dos membros organizacionais.

Dessa forma, cada organização terá uma cultura organizacional distinta, decorrente das diferentes normas, crenças, regras e relações que ocorrem em cada uma delas, e por ter o poder de mudar o rumo da organização a mesma deve manter uma cultura enraizada nos seus princípios e ao mesmo tempo flexível, devendo estar sempre atenta aos acontecimentos tecnológicos e preocupada com a gestão de pessoas.

Assim, a cultura organizacional mostra-se um fator de extrema importância para as empresas, pois além de servir como um guia para alinhar os comportamentos dos funcionários no dia a dia de trabalho, a mesma pode contribuir tanto para a construção de uma identidade organizacional positiva quanto uma imagem negativa como um todo, além de influenciar diretamente no clima da organização.

\section{Clima organizacional}

O termo clima organizacional é usado para se referir à percepção coletiva que os funcionários de uma empresa têm sobre a organização. Por esse motivo ele é um dos maiores indicadores do estado de ânimo individual e geral dos membros da corporação.

Luz (2012, p. 20) afirma que o clima organizacional pode ser afetado por fatores externos (condições de saúde, habitação, lazer e família) ou pelas próprias condições sociais dos colaboradores, ou seja, dentre os diversos fatores que podem alterar o clima de uma organização, o mais comum é que seja afetado por sua cultura.

Por esse motivo é de fundamental importância que os gestores, líderes imediatos e os profissionais de Recursos Humanos estejam sempre atentos a isto, pois é a partir dessa percepção do clima da organização e dos fatores que o influenciam que poderão tomar decisões assertivas para garantir um cenário de trabalho mais saudável.

Segundo Srour (2012) é importante ressaltar que os conceitos de cultura e de clima organizacional não são intercambiáveis, ou seja, o clima não apanha os modos institucionalizados de agir e de pensar, pois seu eixo consiste em capturar a "temperatura social" que prevalece na organização. E além do fator cultural organizacional, existem diversos aspectos que também influenciam no clima organizacional. Há um conjunto de 
fatores que são divididos em: psicológicos, físicos, sociais, de comunicação e econômicos (DIAS, 2013).

\section{Fatores psicológicos}

São constituídos pela soma de todos os elementos que podem ou não motivar o indivíduo, entre eles: a motivação, que pode ser definida como a vontade que o colaborador tem para realizar os esforços necessários para alcançar as metas da organização; o nível de satisfação, que se refere ao grau de concordância entre expectativas de recompensa e o que está recebendo concretamente; a estabilidade funcional, que ocorre quando as mudanças de postos tanto horizontal quanto vertical não são realizadas com transparência; e segurança no emprego, quando a empresa passa por períodos de instabilidade e não informam rapidamente os passos que tomará ou as mudanças que ocorrerão, criando um clima de boatos e insegurança nos funcionários, desmotivando-os.

\section{Fatores físicos}

Dentre os fatores físicos há a disposição do espaço, que se refere à distância entre as pessoas e as instalações, o que pode exercer uma forte influência na interação social; o tamanho da organização, pois a distância que separa os departamentos e setores gera maior ou menor proximidade das pessoas e altera o clima; a iluminação, que em um ambiente de trabalho influi na execução das tarefas, pois contribui para melhor visualização dos objetos e leitura; e o ruído, já que em um ambiente de trabalho com altas doses de ruídos facilita a ocorrência de erros devido à falta de concentração.

\section{Fatores sociais}

Dentre os fatores sociais destacam-se o papel do fundador, pois a presença do mesmo no ambiente de trabalho pode atrapalhar o rendimento, pois suas atitudes e opiniões passam a ser referência; os estilos de liderança, já que nos diversos níveis hierárquicos uma liderança estável dá segurança à equipe que lidera e um líder instável provoca instabilidade e desmotivação na equipe; e o grupo dominante, pois em toda organização há um grupo que constitui referência e pode ser formado por dirigentes ou até mesmo um grupo informal que tem domínio no que faz. 


\section{Fatores de comunicação}

É uma maneira de conhecer as ideias, fatos, pensamentos, sentimentos e valores dos outros. É importante que haja uma comunicação efetiva nas organizações. Caso não ocorra pode haver um desequilíbrio na equipe de trabalho. As novas tecnologias (celulares, internet, etc.) permitem que se estabeleçam novas formas de comunicação, dessa forma o contato pode ser mais efetivo, facilitando o acesso dos postos mais baixos na escala hierárquica com os dirigentes.

\section{Fatores econômicos}

Quando a remuneração não é adequada ou quando ocorre com atrasos frequentes gera um clima contínuo de instabilidade e insatisfação. O pagamento pelo bom empenho, tanto individual quanto em equipe, gera um ambiente competitivo positivo onde o mérito é valorizado. Os aumentos periódicos e o recebimento de prêmios por mérito é fundamental para um bom desempenho, pois tendem a criar um ambiente positivo e valorizado pelos funcionários.

\section{Qualidade de vida no trabalho: saúde $X$ doença}

Pode-se definir a qualidade de vida no trabalho como um conjunto de fatores que colaboram para o bem-estar físico e emocional dos funcionários de uma empresa. Segundo Sant'Anna e Kilimnik (2011):

Foi com a revolução industrial e a sistematização dos métodos de produção, nos séculos XVII e XIX, que as condições de trabalho e sua influência sobre a produção e a moral dos trabalhadores passaram a ser estudadas de forma científica. (SANT'ANNA \& KILIMNIK, 2011, p. 3).

Atualmente é notório que a qualidade de vida no trabalho tem grande influência do clima organizacional, pois os funcionários passam grande parte de seu dia na empresa. Por esse motivo é essencial que os mesmos sintam-se à vontade para exercerem suas atividades da melhor maneira possível.

Os líderes devem se atentar às situações acerca da organização, pois o que pode parecer produtividade para a chefia imediata, o colaborador pode estar tendo a percepção de pressão e demanda demasiadamente intensa. Essa busca do equilíbrio entre as necessidades, expectativas e recursos que o trabalhador possui, as necessidades, expectativas e demandas das organizações têm sido um desafio para a humanidade. (ZANELLI, 2010). 


\section{Estresse ocupacional}

Quando o organismo se encontra numa posição de perigo são mobilizados recursos fisiológicos que o prepara para o enfrentamento através de diversos mecanismos de defesa.

A esse respeito Cosenza (2021) afirma que:

o estresse agudo, portanto é um bom estresse, que nos mobiliza para enfrentar situações significativas. Porém se essas situações se prolongam, tem origem o estresse crônico, um fenômeno que causa desequilíbrio, patologias e tem repercussão até na longevidade. (COSENZA, 2021, p. $4)$.

O estresse relacionado ao ambiente de trabalho, sem dúvidas, gera um impacto na saúde física e mental do trabalhador e pode dar origem a vários problemas psicológicos como dores de cabeça, irritabilidade, alterações do sono, ansiedade, dificuldades de concentração e de tomada de decisão, sintomas depressivos ou até mesmo quadros psiquiátricos, como por exemplo, depressão, síndrome de burnout e Distúrbio de Stress Pós-traumático (D.S.P.T.).

Dentre as doenças mais relacionadas ao mau clima organizacional, o estresse é a mais comum e está relacionada a uma das doenças mais preocupantes ao bem-estar do colaborador. Este tipo de doença pode acarretar danos à saúde física e mental, assim prejudicando o desempenho nas atividades exercidas.

Fiorelli (2007) ressalta que pequenos problemas que ocorrem no dia a dia, gerando aborrecimentos diários, que por vezes parecem insignificantes, se acumulados, acabam gerando uma fonte de estresse. Sendo assim, é importante se atentar a essas pequenas coisas que se tornam rotineiras e que podem até parecer inofensivas, como a distribuição desigual das atividades por parte dos gestores, o que acaba gerando sobrecarga para alguns; metas inalcançáveis, que causam trabalho excessivo e desgaste físico e mental, sem chances de alcançar o resultado desejado; a falta de colaboração entre os membros da equipe; má relação com a chefia; falta de feedback positivo; sentimento de desvalorização ou remuneração incompatível com a função; falta de flexibilidade, etc. Essas entre outras ações do dia a dia podem contribuir para o aumento do nível de estresse, pois o profissional pode até não perceber de imediato, mas com o passar dos dias ele tende a se sentir mais desmotivado e estressado com a rotina de trabalho, podendo esses acontecimentos levar ao mais alto nível de estresse no futuro.

\section{Consequências do estresse}

Para Fiorelli (2007), as fontes de pressão do estresse podem manifestar diversos sintomas nas pessoas, tanto no nível pessoal (dor nos ombros e coluna, depressão, aumento da 
pressão arterial, irritabilidade acentuada, dentre outros) como organizacional (absenteísmo, rotatividade, queda na qualidade da produção, dentre outros). Tais sintomas podem acarretar nas pessoas o desenvolvimento de patologias físicas e mentais, como problemas do coração, úlcera, gastrite, esgotamento, etc. Outra condição relacionada a todos os outros fatores citados anteriormente é o a síndrome de burnout. O termo vem do inglês e numa tradução livre significa queimar. Segundo o Dicionário Online de Português (2019) é definido como um distúrbio psíquico ocasionado pelo excesso de trabalho, sendo capaz de levar alguém à exaustão extrema, ou seja, um grau de estresse generalizado e esgotamento físico. Esse termo é exclusivamente ligado à vida profissional, a esse sofrimento que está diretamente ligado ao mau clima organizacional, como por exemplo: cobranças excessivas vindas da chefia, estabelecimento de metas inalcançáveis, assédio moral vindo dos gestores, ou até mesmo bullying praticado por pessoas do mesmo nível hierárquico; sem falar nas fofocas que geram intrigas entre os colaboradores e a falta de espaço para ser ouvido. Esses entre outros fatores podem gerar o sofrimento do trabalhador, que nasce por consequência das relações de trabalho e a partir da cultura organizacional.

As organizações podem adotar algumas intervenções que permitem ajudar os profissionais a gerir o stress, a prevenir ou minimizar o burnout e a promover o bem-estar: oferecer condições favoráveis para o trabalho (ambiente físico adequado - iluminação, ventilação, limpeza, organização); realizar treinamentos constantes para os gestores de como gerir um bom clima organizacional; observar como andam as relações de trabalho para eliminar a relação abusiva entre supervisores e subordinados, se houver; evitar longas horas de trabalho e ciclos ininterruptos; e incentivar e oferecer programas de qualidade de vida. Estas são algumas das medidas que podem ser adotadas pelas organizações.

\section{METODOLOGIA}

Este artigo foi elaborado com o objetivo de apresentar os benefícios que as empresas e seus colaboradores podem ter ao cultivar um bom clima organizacional, bem como ressaltar as doenças ocupacionais e outros pontos negativos que o mau clima de uma organização pode gerar para ambos. Neste trabalho, especificamente, pretende-se:

a) Identificar os principais fatores que se relacionam ao mau clima organizacional, podendo gerar danos psicológicos e financeiros aos colaboradores e às empresas;

b) Compreender as principais medidas que podem ser tomadas pelas empresas para diminuir o estresse, cultivar um bom clima organizacional e manter os funcionários 
motivados e produtivos.

A pesquisa foi bibliográfica e de campo, focada numa análise propositiva, na forma qualitativa, dividida em três etapas. Na primeira foi realizada a revisão bibliográfica sobre cultura e clima organizacional, buscando a definição da base conceitual em livros. A segunda consistiu em realizar uma pesquisa de campo para coleta dos dados, que utilizou como principal ferramenta um questionário semiaberto. E a terceira etapa consistiu em relacionar o referencial teórico com os dados obtidos na pesquisa de campo para realizar uma análise crítica entre teoria e prática.

Em decorrência da pandemia de COVID-19 a pesquisa de campo foi realizada de forma 100\% online, através de um questionário do Google Forms, e enviado por e-mail ou WhatsApp para um total de 80 pessoas. A pesquisa esteve focada na percepção do clima organizacional pela visão dos colaboradores diante de suas realidades no dia a dia de trabalho e não na empresa como um todo. Os participantes têm faixa etária entre 25 e 55 anos e exercem cargos operacionais numa empresa privada, do ramo de serviços logísticos, que fica localizada no centro do Cabo de Santo Agostinho, cidade do estado de Pernambuco. A empresa foi denominada Transportadora Alfa (nome fictício) para preservar a identidade da instituição.

\section{ANÁLISE DA PESQUISA DE CAMPO}

1- Você acha que sua equipe de trabalho cultiva um bom clima organizacional? 80 respostas

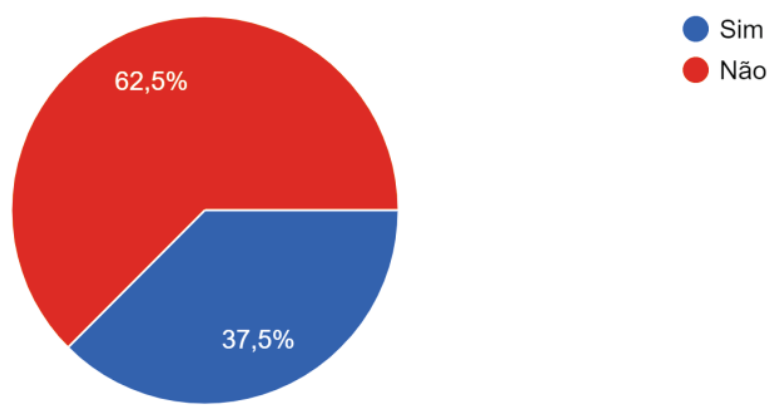

Vimos, através da pesquisa bibliográfica, que quando existe um bom clima organizacional as pessoas trabalham mais satisfeitas, no entanto, quando esse clima é tenso, torna os colaboradores preocupados, insatisfeitos. Entre os participantes da pesquisa 50 
responderam que sua equipe não cultiva um bom clima organizacional, e os outros 30 participantes responderam que o bom clima é cultivado na equipe.

2-Os funcionários são tratados com respeito independente do cargo?

80 respostas

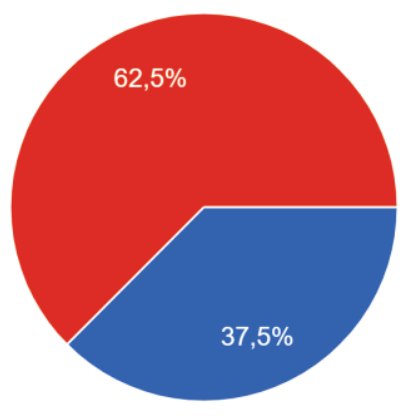

Sim

Não

Neste resultado, observa-se que na percepção dos participantes os colaboradores não recebem um tratamento igualitário independentemente do cargo. Isso não deve acontecer, pois é fundamental que os líderes e liderados de uma empresa tenham ciência de que todos os cargos são importantes dentro de uma organização, e todos devem ser tratados de maneira igualitária.

3- Na empresa em que trabalha, as pessoas mais competentes têm as melhores oportunidades? 80 respostas

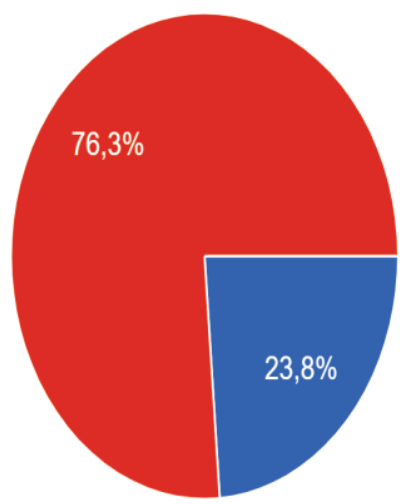

Como é perceptível no gráfico, a maioria dos entrevistados não acham que os colaboradores mais competentes têm melhores oportunidades. Esta pode ser uma demonstração de insatisfação. 
4- Existe cooperação entre os diversos setores da empresa?

80 respostas

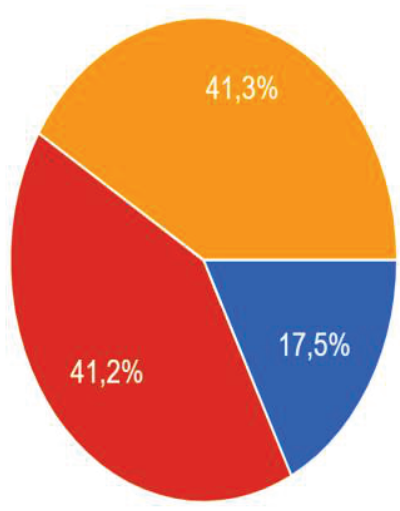

$\operatorname{Sim}$

Não

As vezes

Observamos que, na percepção dos entrevistados, a cooperação entre os diversos setores de suas respectivas empresas está deixando a desejar, pois 33 dos participantes disseram que não há cooperação, enquanto outros 33 disseram que apenas às vezes, e apenas 14 disseram que a cooperação é efetiva.

5- Você acredita que seu trabalho é avaliado de forma justa pelos seus gestores? 80 respostas

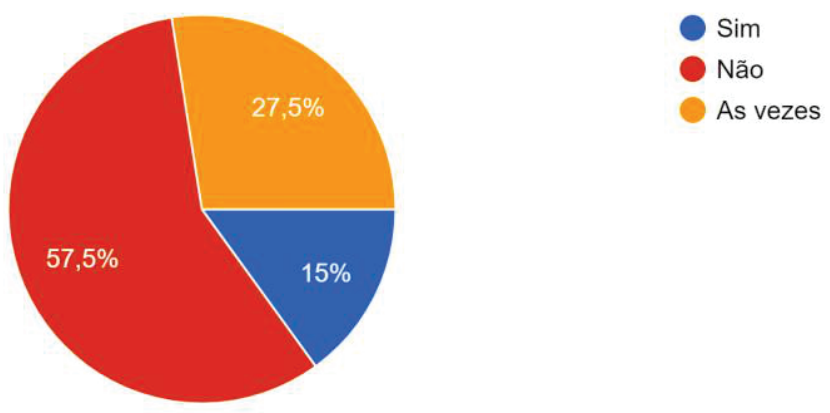

No gráfico acima verificamos que na maioria das vezes os colaboradores não têm seus esforços reconhecidos. 
6- Você recebe o reconhecimento devido quando faz um bom trabalho?

80 respostas

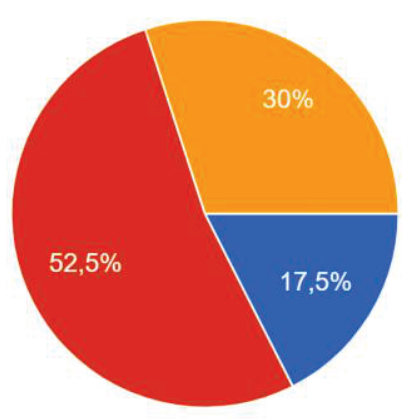

Sim

Não

As vezes

Neste gráfico é possível observar a insatisfação dos colaboradores que participaram da pesquisa ao sentir que seus esforços não são valorizados quando realizam um bom trabalho.

7- Seu gestor exerce pressão sobre seu ritmo de trabalho?

80 respostas

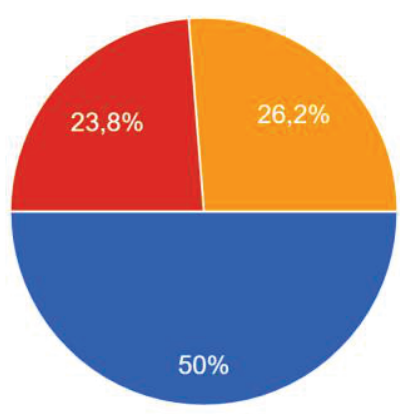

Cinquenta por centos dos participantes afirmam que trabalham sob pressão da chefia, enquanto os outros $26 \%$ relatam que às vezes se sentem pressionados. Apenas $23,8 \%$ não se sentem pressionados. 
8-Já sentiu que deixou seus problemas de trabalho interferirem na sua vida pessoal?

81 respostas

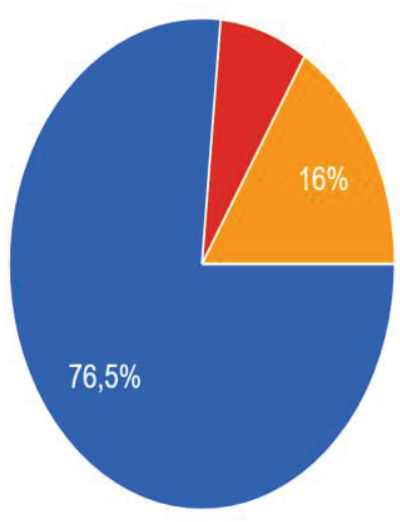

Sim

Não

As vezes

O gráfico acima mostra que $76,5 \%$ já deixaram os problemas de trabalho afetar sua vida pessoal de alguma forma.

10- Você acredita que o estresse causado no ambiente de trabalho pode prejudicar seu desempenho e rendimento profissional.

80 respostas

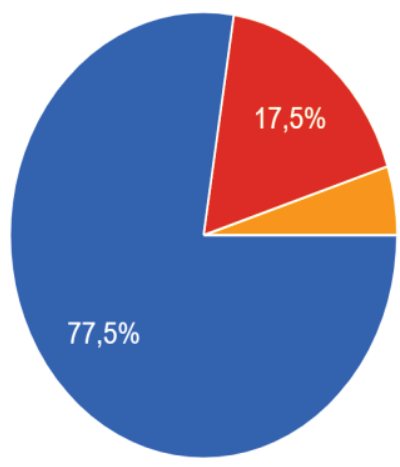

Sim, muito!

Nem tanto.

Não prejudica.

Observamos que a maioria dos participantes acredita que o estresse causado no ambiente de trabalho prejudica o rendimento de suas atividades laborais. 
11- A que fator você relaciona seu estresse no trabalho?

80 respostas

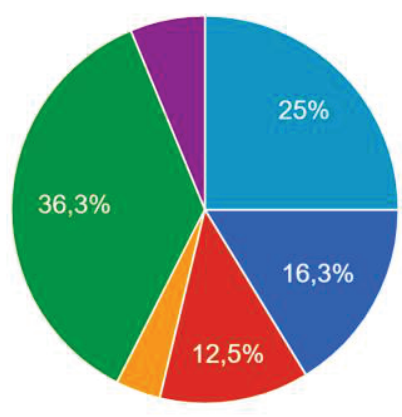

Mau clima organizacional

Salário a baixo da média

Má relação com a chefia.

Sentimento de desvalorização.

Metas inalcançáveis

Outros

Verificamos no gráfico acima que, para os participantes, o fator mais relacionado ao estresse no trabalho é o sentimento de desvalorização. 16,3\% relacionam o estresse ao mau clima organizacional. $12,5 \%$ se sentem estressados por salários abaixo da média, entre outros.

12- Escolha uma das alternativa que você acredita que melhoraria sua qualidade de vida no trabalho?

80 respostas

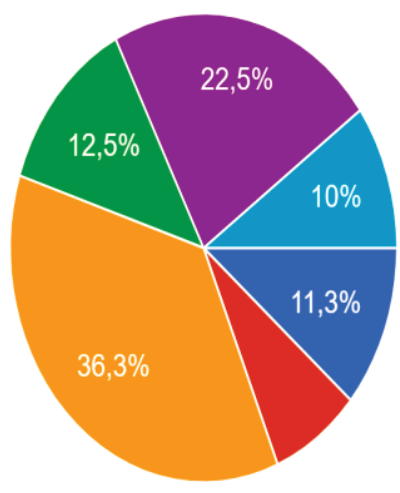

Flexibilidade de horário

Metas reais(atingiveis)

Programas de reconhecimento

Liderança horizontal (aproxima as pessoas e proporciona uma maior integração entre líderes e liderados)

Salário Mais alto

Outros

Quando questionados sobre melhorias na qualidade de vida no trabalho $36,3 \%$ apontaram para a necessidade de programas de reconhecimento. $22,5 \%$ citaram como melhoria a oferta de salários mais altos. Para 12,5\% uma liderança com maior interação com os liderados seria uma indicação de melhora. 11,3\% apontaram a flexibilidade de horário, e 10\% outros. 
13- Já precisou fazer uso de medicamentos para problemas relacionados ao estresse no trabalho? 80 respostas

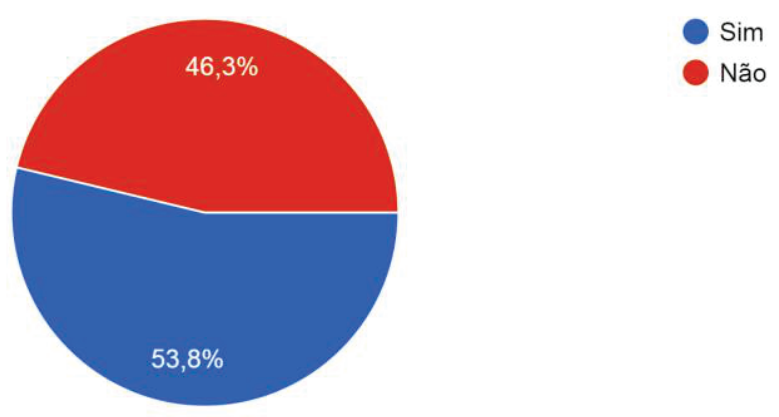

O gráfico acima mostra que mais da metade dos pesquisados já fizeram uso de medicamentos para problemas relacionados ao estresse no trabalho.

\section{4 - Se sim, para qual problema?}

$\mathrm{R}=$ Os remédios mais citados nessa questão aberta foram para as seguintes condições de saúde: dores de cabeça, enxaqueca, dores no corpo e pescoço, ansiedade. Alguns relataram que já necessitam de remédios para quadros de saúde mais agravados como: gastrite nervosa, calmantes e hipertensivos.

15- No geral, você está satisfeito com o clima organizacional da sua empresa?

80 respostas

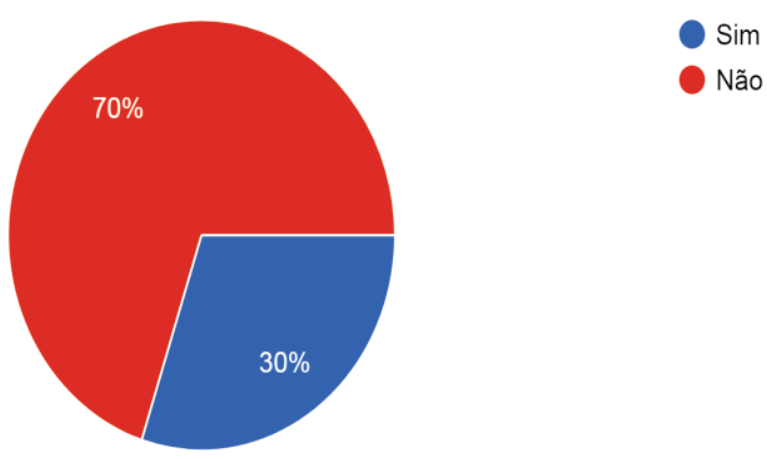

Visualizando o gráfico, fica claro que o índice de insatisfação dos participantes desta pesquisa está mais elevado que os de colaboradores satisfeitos com suas empresas. 56 estão insatisfeitos e apenas 24 satisfeitos com o clima organizacional de seus empregos atuais. 


\section{CONSIDERAÇÕES FINAIS}

Através do estudo bibliográfico e de campo, constatou-se que a cultura organizacional e liderança de uma empresa influenciam diretamente no clima organizacional da mesma, assim como o clima organizacional está diretamente ligado ao bem estar dos colaboradores, a vontade dos mesmos permanecerem por mais tempo no local e a sua produtividade. Através da pesquisa confirmou-se também que altos níveis de estresse causado pelo mau clima podem ocasionar perdas no desempenho profissional e queda na produtividade dos colaboradores, ocasionando doenças ocupacionais e turnover, enquanto as empresas que investirem em qualidade de vida podem gerar o efeito contrário, ou seja, um ambiente de trabalho saudável e favorável, aumento do desempenho e da produtividade, além de diminuir a rotatividade de funcionários.

Através dos resultados obtidos na pesquisa de campo os principais motivos que causam a insatisfação no trabalho para o grupo de pessoas pesquisadas neste trabalho são: falta de colaboração entre a equipe de trabalho e entre os setores; sentimento de desvalorização; falta de tratamento e oportunidades de forma isonômica; mau clima organizacional; excesso de pressão no ritmo de trabalho; e salários abaixo da média.

Diante do problema apresentado sugerimos algumas medidas que podem ser tomadas para construir um ambiente de trabalho saudável:

Investir na capacitação da liderança é primordial, pois bons líderes auxiliam na construção de um ambiente de trabalho saudável, enquanto os líderes mal capacitados podem adoecer a equipe. Outro fator importante para essa questão seria criar uma cultura de valorização dos profissionais através de feedback positivo para reconhecer um bom trabalho realizado. Deve-se adotar um programa de carreiras para proporcionar o crescimento vertical dos trabalhadores que se destacam por seu bom desempenho. É aconselhável trabalhar com metas realistas para evitar sobrecargas e frustrações, além de aderir a um tratamento igualitário nas relações de trabalho independentemente do cargo ou nível hierárquico dos colaboradores.

É preciso entender que só elogios não são suficientes para reter talentos, portanto, é interessante estabelecer recompensas financeiras atrativas, sejam através de um salário de mercado competitivo, de programas de incentivo como promoções, bonificações em dinheiro ou premiações que têm como principal objetivo reconhecer, estimular e retribuir o engajamento e o desempenho dos colaboradores e das equipes de trabalho, além de contribuir para a retenção dos talentos e melhora do clima organizacional. 


\section{REFERÊNCIAS}

CHIAVENATO, Idalberto. Gestão de pessoas: o novo papel dos recursos humanos nas organizações. Rio Janeiro: Elsevier, 1999.

COSENZA, M. Ramon. Neurociência e mindfulness: meditação, equilíbrio emocional e redução do estresse. Porto Alegre: Artmed, 2021.

DIAS, Reinaldo. Cultura Organizacional: Construção, Consolidação e Mudanças. São Paulo: Atlas, 2013.

DICIO. Dicionário Online de Português. Porto: 7 Graus, 2019. Disponível em: https://www.dicio.com.br/burnout/. Acesso em: 30 abr. 2021.

FIORELLI, José Osmir. Psicologia para administradores. Integrando Teoria e Prática. 5. ed. São Paulo: Atlas, 2007.

LUZ, Ricardo. Gestão do clima organizacional. Rio de Janeiro: Qualitymark, 2012.

ROBBINS, Stephen P.; SOBRAL, Filipe. Comportamento organizacional. 14. ed. São Paulo: Prentice-Hall, 2012.

SANT'ANNA, Anderson de Souza; KILIMNIK, Zélia Miranda. Qualidade de vida no Trabalho: Abordagens e Fundamentos. Rio de Janeiro: Elsevier, 2011.

SCHEIN, Edgar H. Cultura organizacional e liderança. São Paulo: Atlas, 2009.

SIQUEIRA, Mirlene Maria Matias. Medidas do Comportamento Organizacional. São Paulo: Artmed, 2012.

SROUR, Robert Henry. Poder, cultura e ética nas organizações. 3. ed. Rio de Janeiro: Elsevier, 2012.

ZANELLI, José Carlos. Estresse nas organizações de trabalho: compreensão e intervenção baseadas em evidências. Porto Alegre: Artmed, 2010. 


\section{APÊNDICE A - Pesquisa de Clima Organizacional aplicada aos entrevistados}

1- Você acha que sua equipe de trabalho cultiva um bom clima organizacional?

2- Os funcionários são tratados com respeito independente do cargo?

3- Na empresa em que trabalha, as pessoas mais competentes têm as melhores oportunidades?

4- Existe cooperação entre os diversos setores da empresa?

5- Você acredita que seu trabalho é avaliado de forma justa pelos seus gestores?

6- Você recebe o reconhecimento devido quando faz um bom trabalho?

7- Seu gestor exerce pressão sobre seu ritmo de trabalho?

8- Já sentiu que deixou seus problemas de trabalho interferirem na sua vida pessoal?

9-Você acredita que o estresse causado no ambiente de trabalho pode prejudicar seu desempenho e rendimento profissional.

10- A que fator você relaciona seu estresse no trabalho?

11- A que fator você relaciona seu estresse no trabalho?

12-Escolha uma das alternativas que você acredita que melhoraria sua qualidade de vida no trabalho:

13- Já precisou fazer uso de medicamentos para problemas relacionados ao estresse no trabalho?

14- Se sim, para qual problema?

15-No geral você está satisfeito com o clima organizacional da sua empresa? 


\title{
DIFICULDADES DE APRENDIZAGEM NA LEITURA E NA ESCRITA DE
} ALUNOS DO $2^{\circ}$ ANO DO ENSINO FUNDAMENTAL I

\author{
https://dx.doi.org/10.48097/2674-8673.2021n5p05
}

\author{
Andreza Marques de Melo Lima ${ }^{1}$ \\ Cláudia Patrícia Pinheiro Viana Ximenes ${ }^{2}$ \\ Silvia Rodrigues Cavalcanti Isaltino ${ }^{3}$
}

\section{RESUMO}

O presente trabalho teve por objetivo analisar a intervenção pedagógica dos professores frente às dificuldades de aprendizagem na leitura e na escrita de alunos do $2^{\circ}$ ano do ensino fundamental I. Optou-se por uma pesquisa de caráter qualitativa, bibliográfica e com pesquisa de campo, através do uso de questionário online, devido ao momento da pandemia da COVID- 19. Participaram quatro (4) professores da escola particular Felipe Magalhães, situada em Jaboatão dos Guararapes - PE. O embasamento teórico contou com a contribuição de Soares (1998), Veiga (2002), Leite (2012), dentre outros. Por fim, verific ouse que as dificuldades de aprendizagem advêm de diversos fatores que podem atingir grande parte dos alunos, representando um desafio que precisa ser superado no âmbito escolar. A intervenção pedagógica para a superação de tais dificuldades deve ser no sentido de mudança no papel do professor e da metodologia adotada em sala de aula, criando projetos, momentos lúdicos e oficinas pedagógicas com o intuito de prevenir e/ou acabar com as dificuldades identificadas.

Palavras-chave: Dificuldade de aprendizagem. Papel do professor. Intervenção pedagógica.

Data de submissão: $12 / 03 / 2021$

Data de aprovação: 14/05/2021

\begin{abstract}
The present study aimed to analyze the pedagogical intervention of teachers in the face of learning difficulties in reading and writing in students of the 2nd year of elementary school I. We opted for a qualitative, bibliographic research with field research, through the use of an

\footnotetext{
${ }^{1}$ Graduanda do Curso de Licenciatura em Pedagogia da Faculdade Metropolitana da Grande Recife.

E-mail: andrezamelox@gmail.com

${ }^{2}$ Graduanda do Curso de Licenciatura em Pedagogia da Faculdade Metropolitana da Grande Recife.

E-mail: cpatriciavianaximenes@outlook.com

${ }^{3}$ Professora/Orientadora do Curso de Licenciatura em Pedagogia da Faculdade Metropolitana da Grande Recife.

E-mail: silvinharca@hotmail.com
} 
online questionnaire, due to the time of the COVID-19 pandemic. Four (4) teachers from the private school Felipe Magalhães, located in Jaboatão dos Guararapes - PE, participated. The theoretical basis had the contribution of Soares (1998), Veiga (2002), Leite (2012), among others. Finally, it was found that learning difficulties arise from several factors that can affect a large part of students, representing a challenge that needs to be overcome in the school environment. The pedagogical intervention to overcome such difficulties must be in the sense of changing the role of the teacher and the methodology adopted in the classroom, creating projects, playful moments and pedagogical workshops in order to prevent and / or end the difficulties identified.

Keywords: Learning disability. Teacher's role. Pedagogical intervention.

\section{INTRODUÇÃO}

Ao refletir sobre a educação escolar é possível perceber que existem inúmeros elementos que influenciam no processo de ensino-aprendizagem dentro do contexto de sala de aula. Dentre esses, é necessário considerar as dificuldades de aprendizagem, que aparecem como obstáculos na condução desse processo. Entretanto, é importante ter em mente que tais dificuldades não impedem a aquisição da aprendizagem, visto que todo aluno é capaz de aprender, desde que a ele seja dado todo suporte necessário para sua construção do conhecimento.

Em estudo realizado anteriormente por uma das presentes pesquisadoras, foi possível analisar a maneira como as dificuldades de aprendizagem podem ser abordadas através da intervenção psicopedagógica, gerando assim uma alternativa para amenizar o problema em questão.

Contudo, considerando a necessidade de se observar o referido tema, através de uma perspectiva multidisciplinar, e reconhecendo o fundamental papel do professor na condução desse processo educativo, o referido trabalho volta-se para discutir as dificuldades de aprendizagem, através de um olhar pedagógico, centrado na sala de aula do ensino fundamental I.

De acordo com Leite (2012), as dificuldades de aprendizagem (DA) correspondem a uma categoria ampla de fenômenos que podem influenciar negativamente no aprendizado, como por exemplo: a realidade socioeconômica da população, a falta de estímulo por parte da família, a formação inadequada dos professores, uma metodologia que não contempla as diversas formas de aprender dos estudantes, etc.

De tal modo, cabe ao professor em sala de aula, como mediador, ter um olhar crítico, ter a capacidade de avaliar e identificar qual o melhor método a ser usado para ajudar aquele aluno a superar essa dificuldade para não se tornar um trauma/bloqueio, causando desânimo, 
desinteresse ou até mesmo o abandono da escola. Cada pessoa tem uma forma própria de assimilar conhecimentos e traz consigo uma bagagem cultural. Então, diante das dificuldades encontradas, o papel do professor é o de ajudar a integrar o aluno no processo de aprendizagem. O professor precisa entender o aluno e entender o fato de que ele precisa aprender sobre o mundo de maneira cautelosa e no seu próprio tempo. (GADOTTI, 2003).

Nesse sentido, destaca-se o papel do professor na condução do processo de aprendizagem diante do aluno com dificuldade, gerenciando a construção do conhecimento, negociando com os seus desafios e as suas possibilidades, reconhecendo as diferenças dos seus alunos e considerando os conhecimentos e as experiências de vida que esses trazem consigo.

Assim, surge a motivação para desenvolver o presente trabalho, combinada com a experiência profissional das pesquisadoras, que atuam no $2^{\circ}$ ano do ensino fundamental e identificam alunos com tais dificuldades, principalmente na leitura e na escrita. Através dessa experiência foi possível perceber a necessidade de uma alta demanda de conhecimentos por parte dos professores para lidarem com as dificuldades na sala de aula, desenvolvendo práticas que não venham a excluir esse educando e nem o identificar como incapaz de aprender.

A partir disso algumas indagações surgiram. Quais são essas dificuldades de aprendizagem? Qual o papel do professor diante da dificuldade da criança na aprendizagem da leitura e da escrita? Qual proposta de intervenção pedagógica auxiliará alunos com dificuldades de aprendizagem na leitura e na escrita?

Levando em consideração a relevância do tema, a presente pesquisa pretende contribuir com as discussões voltadas para o cenário educacional, para a prática do professor dentro de sala de aula, e para as dificuldades de aprendizagem que surgem no processo escolar, desmistificando antigos conceitos que consideram tais alunos como incapazes de obter sucesso escolar.

\section{O PROCESSO DE APRENDIZAGEM DA LEITURA E DA ESCRITA}

Diferente do que se pensa no senso comum, o processo de aprendizagem da leitura e da escrita não se inicia no espaço escolar. Na verdade, esse processo acontece desde o início da vida da criança, através de diversas interações no seio familiar. Esse contato se estabelece através de atividades corriqueiras e cotidianas, estimulando, assim, a aquisição desses conhecimentos.

É preciso ter uma visão mais abrangente do processo de aprendizagem, uma vez que o 
indivíduo é um ser bastante complexo e há vários fatores que influenciam no seu desenvolvimento cognitivo, tais como: fatores genéticos e biológicos, o convívio social, os estímulos recebidos pela família, pela cultura local, pela escola, pelos amigos, pelos professores, etc. A aprendizagem requer a compreensão do indivíduo como um ser completo, levando em consideração os aspectos psicomotor, afetivo e cognitivo.

Assim, a educação recebida na escola, na família e na sociedade cumpre um papel primordial na constituição dos sujeitos, visto que tais instâncias interferem no desenvolvimento individual e, consequentemente, no desempenho da criança na aprendizagem. (VYGOTSKY, 1984).

Conforme se sabe, a leitura e a escrita são, desde sempre, muito importantes para a vida em sociedade, influenciando nas formas de comunicação e expressão e facilitando o diálogo entre os indivíduos. A escrita surgiu por volta de 3.000 a. C. O homem, mesmo sem a escrita, buscava comunicar-se através de desenhos realizados nas paredes das cavernas. Através desses desenhos revelou-se uma forma de comunicação humana, a qual servia para trocar mensagens, transmitir ideias, desejos, alegrias, sofrimentos e necessidades. Isso foi evoluindo ao longo dos anos, passando por símbolos até chegar às letras do nosso alfabeto.

Porém, junto com a evolução e a formação das civilizações em sociedade, vieram também práticas excludentes, as quais limitavam o ensino e aprendizagem da leitura e da escrita apenas para pessoas de classes sociais mais altas. Tal exclusão acarretou inúmeros problemas para grande parcela da sociedade, influenciando nos índices de dificuldade de aprendizagem.

No atual contexto escolar brasileiro, percebe-se que o país passou por um processo de democratização no acesso às escolas, garantindo que crianças de todas as classes sociais possam frequentar e construir conhecimentos nesse espaço educativo. Entretanto, tal acesso não veio combinado com a garantia da qualidade desse ensino, o qual ainda precisa ser melhorado. O processo de alfabetização não pode ser entendido como meramente o ensino para a "codificação" e a "decodificação". Alfabetizar vai além do simples ato de ler e escrever, conduzindo a outras práticas sociais. (CEEL 2007).

Tendo em vista que aprender deve ser um ato desejante do indivíduo que aprende, vale destacar que a escola precisa suscitar no aluno o desejo de aprender, conduzindo a aprendizagem não através de métodos tradicionais, mecânicos e esvaziados de sentido, mas sim de forma significativa, com descontração e oferecendo situações interessantes e estimulantes, pois quando o ato de aprender é colocado como algo prazeroso e satisfatório tem-se o desejo e a vontade de aprender. 
Segundo Kleiman (2002), a aprendizagem da criança na escola deve estar fundamentada na leitura, pois interpretar e compreender os elementos sociais são aspectos fundamentais e sem essas bases não tem como a criança obter sucesso em nenhuma atividade que lhe for apresentada.

\section{Dificuldade de aprendizagem na leitura e escrita}

Nas últimas décadas um dos problemas educacionais que mais vem ganhando destaque nos debates acadêmicos são as dificuldades de aprendizagem. Para melhor compreender tal discussão, é preciso levar em consideração que o problema de aprendizagem não deve ser combatido apenas a partir do momento que a criança já está apresentando tais dificuldades na escola, visto que a prevenção e o prévio diagnóstico são fundamentais para evitar que essas se instalem.

Apesar de ser um fenômeno antigo, não é fácil apresentar uma definição para as dificuldades de aprendizagem de leitura e escrita, pois essas englobam diferentes fatores como: desenvolvimento social, aspectos comportamentais, fatores cognitivos, etc. Kikr (1962) ressalta que uma dificuldade de aprendizagem se refere a um transtorno ou desenvolvimento lento em um ou mais processo da fala, linguagem, leitura, escrita ou outras áreas escolares, resultante de uma deficiência causada por uma possível disfunção cerebral, alteração emocional ou condutual. As dificuldades de aprendizagem da leitura podem revelar-se na dificuldade da leitura oral, dificuldade na leitura silenciosa e dificuldade na compreensão da leitura e consequentemente da escrita.

Segundo Nunes (2001), "todas as crianças têm dificuldades na leitura e na escrita, que é uma atividade complexa. Até certo ponto, o ritmo que ela supera essas dificuldades pode ser antecipado". Nota-se, assim, que as dificuldades de aprendizagem estão presentes no cotidiano das escolas e afetam todos os tipos de educandos.

Conforme a visão de Pain (1992):

O problema de aprendizagem é considerado um processo diferente do contrário de aprender. É um processo particular de um sistema que se equilibra e precisa adotar determinado tipo de comportamento que determina o não aprender e que cumpre assim sua função positiva. (PAIN, 1992, p. 10).

No entanto, vale ressaltar que cada vez mais é possível encontrar alunos desmotivados a aprender no contexto escolar. Por um lado, pode-se atribuir determinada dificuldade de aprendizagem ao desinteresse do aluno, mas por outro ângulo, a falta de interesse e dificuldade do aluno muitas vezes acontece porque esse não vê sentido naquilo que está sendo 
ensinado em sala de aula. A falta de uma metodologia e de um conteúdo adequado, que converse com a realidade daquele estudante e que possibilite uma participação ativa, influencia na condução do processo de ensino-aprendizagem e, logo, nos índices de dificuldades de aprendizagem da leitura e da escrita.

Diante disso, verifica-se a necessidade de uma formação profissional no sentido de promover uma gama de conhecimentos para que os professores saibam lidar com essas situações em sala de aula, para assim evitar o desinteresse, a evasão, o fracasso escolar, a rotulação e/ou exclusão desses alunos do contexto escolar.

Além disso, a linguagem oral também precisa ser bem trabalhada, porque a criança costuma escrever da forma como se fala/escuta. Simões (2006) ressalta que o professor dos anos iniciais deve conhecer os aspectos fônicos da língua portuguesa para ajudar a criança em relação à língua falada e escrita. Isso exige do professor competência específica para minimizar as dificuldades.

Por fim, é interessante que a intervenção frente às dificuldades de aprendizagem da leitura e escrita no contexto da sala de aula aconteça através de elementos lúdicos, que possam possibilitar uma experiência prazerosa para os alunos, pois assim esses poderão construir os conhecimentos necessários através de uma aprendizagem mais significativa.

\section{O papel do professor na condução do processo educativo escolar frente à dificuldade de aprendizagem}

Se o professor é fundamental na condução do processo educativo escolar como um todo, a sua importância fica ainda mais evidente diante da dificuldade de aprendizagem. $\mathrm{O}$ professor, enquanto mediador da construção do conhecimento, estabelece um contato direto e cotidiano com os seus alunos, sendo possível assim conhecê-los, identificar determinada dificuldade e buscar meios para contornar tal situação.

Cada criança precisa ser compreendida em suas necessidades particulares e cabe ao professor, com seu conhecimento e experiência, saber usar a sua trajetória pedagógica como docente para amenizar e ajudar nesse processo. Para Coelho e José (1996, p. 12-13) “o professor deve estar sempre atento às etapas do desenvolvimento do aluno, colocando-se na posição de facilitador da aprendizagem e calcando seu trabalho no respeito mútuo, na confiança e afeto".

De tal maneira, destaca-se o papel do professor frente às dificuldades de aprendizagem, uma vez que através dele é possível conhecer melhor o porquê das dificuldades dos alunos, sabendo como intervir diante de cada situação. Cabe ao professor eleger o melhor método para 
ensinar aquele aluno, diversificando a metodologia em sala de aula, adaptando os instrumentos de forma a respeitar a forma de cada um de aprender, do seu jeito, no seu tempo e ritmo próprio.

Bossa (1994) assinala que o grande salto para um trabalho efetivo, eficiente e eficaz é o professor descentrar, ou seja, sair de si mesmo para atender e agir com a lógica do outro e, a partir disso, reconstruir a história do sujeito, respeitando a sua singularidade. É perceber em que movimento este ser está indiferenciado, separado ou integrado frente ao conhecimento para o início do resgate.

O professor deve refletir sobre a prática que está sendo utilizada em sala no processo de ensino-aprendizagem, planejando, elaborando e mediando suas aulas a partir da compreensão da particularidade de cada aluno, procurando sempre motivá-lo a aprender. Uma boa mediação estimula a criatividade através de práticas lúdicas e dinâmicas que ajudam o aluno a produzir, criar e construir, fazendo-o pensar ativamente. Nessa perspectiva, construir o conhecimento na sala de aula é sempre uma festa para o aluno. (SANTOS et al, 2009).

Contudo, é importante ressaltar que devido à alta demanda dos professores no contexto escolar, muitas vezes é difícil que esse profissional possa oferecer um atendimento mais específico que venha a suprir a necessidade do aluno com dificuldade de aprendizagem. Por isso, evidencia-se o trabalho multidisciplinar que precisa ser realizado, contando com outros atores e profissionais que possam garantir a esse aluno maiores condições de sucesso. A dificuldade de aprendizagem na leitura e escrita não deve ser considerada como um fracasso, mas sim como um desafio a ser enfrentado.

Okano et al (2004) destaca que lidar com as dificuldades de aprendizagem no ambiente escolar não é uma tarefa fácil. Uma alternativa é a colocação das crianças em programas especiais de ensino, como as salas de reforço ou de recuperação paralela, destinadas aquelas que apresentam dificuldades não superadas no cotidiano escolar.

\section{METODOLOGIA}

A pesquisa científica pode ser definida como um conjunto de procedimentos sistemáticos, fundamentados no raciocínio lógico e que utiliza métodos científicos para encontrar soluções para problemas propostos. (ANDRADE, 2001).

A abordagem adotada nesta pesquisa foi qualitativa, visto que ela permite abordar o problema em questão, destacando alguns pontos de vista e comportamentos de indivíduos ou 
grupos. Minayo (2003) define a pesquisa qualitativa como aquela que trabalha com o universo de significados, motivos, aspirações, crenças, valores e atitudes, o que corresponde a um espaço mais profundo das relações, dos processos e dos fenômenos que não podem ser reduzidos à operacionalização de variáveis.

Tal investigação aconteceu através de pesquisa bibliográfica, a partir de material já produzido sobre o tema, consultando livros, revistas e outros artigos científicos. Foi realizada uma pesquisa de campo com a pretensão de buscar informações a serem documentadas, sendo a coleta de dados realizada por meio de questionários online com os participantes da pesquisa. Estes questionários foram elaborados por meio da análise de conteúdo, com um direcionamento de perguntas com vistas a responder aos objetivos propostos com 4 (quatro) professoras, todas do $2^{\circ}$ ano do ensino fundamental I.

\section{APRESENTAÇÃO E ANÁLISE DOS RESULTADOS}

No decorrer da pesquisa constatou-se que é comum nessa fase de ensino que alguns alunos apresentem dificuldades de aprendizagem na leitura e na escrita, decorrentes, dentre outros fatores, da questão metodológica aplicada pelo professor em sala de aula. Ainda é comum no espaço escolar a adoção de métodos tradicionais de ensino, os quais não contribuem para uma efetiva aprendizagem.

Segundo Carraher e Schliemann (1989), quando uma criança não compreende o método de ensino adotado pelo professor ela se sente frustrada, com problemas de baixa autoestima, ficando desinteressada, desatenta e em certos casos até agressiva.

Logo, vê-se que é muito importante analisar a prática pedagógica para perceber a qualidade da atuação e o envolvimento com a aprendizagem dos educandos, pois é de suma importância entender que nesse processo cada pessoa aprende de forma diferente. Assim, a utilização de uma metodologia mais lúdica, dentro de uma perspectiva construtivista, oportuniza ao aluno mais autonomia no processo de desenvolvimento e aprendizagem.

De acordo com a pesquisa e as análises feitas, pode-se dizer que os alunos podem apresentar tal dificuldade em todas as matérias, uma vez que ler e escrever faz parte de todas as disciplinas. Por isso, é importante que o professor tenha consciência que o aluno apresenta tais dificuldades não por preguiça ou vontade própria e buscar trabalhar em cima dessas dificuldades, tentando recuperar a autoestima. Analisar os métodos de ensino é de fundamental importância para os educadores que enfrentam problemas relacionados à metodologia. 
No que diz respeito ao papel do professor diante dessas dificuldades e as técnicas utilizadas para melhorar o processo de ensino-aprendizagem desses alunos as participantes ressaltam que:

\section{E. M., 66 anos, Pedagoga}

O professor deve ter uma visão diagnóstica para o processo de aquisição da leitura e escrita dos alunos. Uma vez identificadas as dificuldades de cada um, deve-seincentivar a leitura e escrita dos alunos. O aluno que lê, escreve melhor. O papel do professor é diagnosticar as dificuldades dos alunos e planejar métodos para ajudar nessas dificuldades, buscando a família para também procurar ajuda nas dificuldades encontradas.

Devem ser observados o rendimento dos alunos em sala de aula, suas dificuldades em aprender, e o que levam muitos a perderem o interesse pela escola.

\section{E. R., 57 anos, Pedagoga}

O papel do professor deve ser observar, orientar e instruir o aluno na leitura para que o mesmo melhore diante desta circunstância.

Observar se a criança, ao ler o livro, aproxima-o muito do rosto, ou quando vai copiar algo do quadro. Na escrita, observar o tamanho das letras e como o aluno escreve, pois há alguns que escrevem misturando letras maiúsculas com minúsculas. Então, o professor deve orientá-los.

\section{M., 48 anos, Professora formada em Magistério}

Essa visão é simples nos livros didáticos, pois ainda existe termo de memorização das sílabas. O responsável pelo letramento deve dar prioridade e se responsabilizar com o aprendizado do aluno.

O aprendizado é para todos. O professor deve fazer uma diagnose para detectar os alunos com dificuldades de aprendizagem e que não assimilam bem as explicações do professor. Temos sempre que voltar às explicações ou fazer atividades diferenciadas, reconhecendo as peculiaridades e fazendo uma ação que possa ajudar no aprendizado de cada aluno.

Deve-se ainda observar a prática da psicomotricidade e afetividade na sala de aula e fazer uma diagnose comportamental dos alunos, buscando ajuda da família ou de um psicólogo, caso precise. É possivel que algum aluno apresente dificuldades de aprendizagem como a dislexia (leitura e escrita) e a dislalia (troca de letras). 


\section{S. M., 50 anos, Pedagoga com pós-graduação em Gestão Escolar}

O professor deve ter uma visão de facilitador, demonstrando a seus alunos como a leitura é algo maravilhoso. Deve ser um leitor, sempre lendo com entusiasmo. Isso levará à construção da leitura.

Há alunos que já estão no $5^{\circ}$ ano, mas têm muita dificuldade na leitura e, consequentemente, na interpretação. Isso é muito complicado, pois dificulta o entendimento das atividades de forma geral. Problemas na família também dificultam o desempenho dos alunos. As formas abreviadas de escrever também têm sido uma das dificuldades na atualidade, pois nas atividades querem escrever como fazem nas redes sociais.

O papel do professor é tentar descobrir o que está causando a dificuldade da criança na leitura e escrita e acionar a gestão e familiares na busca pela solução. Também deve mudar, se necessário, a metodologia de ensino. É preciso procurar conhecer as causas dessas dificuldades.

Emfim, deve-se observar o desempenho dos alunos em sala de aula; se eles têm dificuldades de ler e interpretar; se escrevem errado ou se não assimilam os conteúdos estudados.

Percebe-se, assim, a necessidade de se ter um novo olhar sobre tais questões, visando ser mais crítico e fundamentando as atividades para proporcionar ao aluno uma aprendizagem mais significativa. Para superar as dificuldades encontradas e promover o avanço cognitivo dos educandos, Piaget (1972) enfatiza que:

O papel do mestre deve ser aquele de incitar a pesquisa, de fazer tomar consciência dos problemas e não aquele de ditar a verdade. Não podemos nos esquecer que uma verdade imposta não é mais uma verdade: compreender é inventar e reinventar, e dar uma lição prematuramente é impedir a criança de redescobrir as soluções por si mesma. (PIAGET, 1972, p. 72).

Acredita-se na possibilidade de sanar as dificuldades de aprendizagem apresentadas pelos alunos, mas para isso é necessário que haja um trabalho voltado para uma ação reflexiva com toda a equipe pedagógica que abrange a direção, professores, pais, alunos e demais profissionais, procurando sempre trabalhar as questões didáticas com os professores, a relação família e escola, planejar estratégias que visem superar dificuldades encontradas, avaliar e assegurar o processo de ensino da aprendizagem de leitura e escrita, rever o currículo, inserir projetos pedagógicos, etc. Dessa maneira, a aprendizagem será satisfatória e significativa.

Assis (1990) menciona que os problemas de aprendizagem podem ser resultado de ambientes familiares que não estimulam as crianças a estudar e acredita que um ambiente familiar com pouca influência sociolinguística pode interferir no desenvolvimento das aptidões e habilidades desempenhadas pela criança. Muitos fatores podem intervir na vida 
escolar de uma criança. Um ambiente doméstico tranquilo e saudável proporcionará uma melhor estabilidade emocional.

Nesse sentido, Carraher e Schliemann (1989) asseveram que a responsabilidade em educar não é só da escola e nem recai apenas sobre a imagem do professor, uma vez que é de competência de todas as instituições sociais envolvidas. A família deve participar junto à escola, pois a ela compete a transmissão de valores morais.

Conforme exposto, não se pode esperar que o professor seja mero transmissor de informações ou que aprenda no ambiente acadêmico o que vai ser ensinado aos alunos, mas sim um docente que produza o conhecimento em sintonia com o aprendiz. Não é suficiente que ele saiba o conteúdo de sua disciplina, pois o mesmo precisa não só interagir com outras disciplinas, como também conhecer o aluno. Esse conhecimento/interação faz parte do papel desempenhado pelo professor pelo fato dele necessitar saber o que ensinar, para quê e para quem, ou seja, como o aluno vai utilizar o que aprendeu na escola em sua prática social.

Por fim, foi possível entender o importante papel do professor em proporcionar uma intervenção pedagógica multidisciplinar utilizando técnicas e estratégias lúdicas que possam prevenir, combater e evitar as dificuldades de aprendizagem na leitura e na escrita dentro do ambiente escolar.

\section{CONSIDERAÇÕES}

Com base na pesquisa bibliográfica e na pesquisa de campo, foi possível observar que as dificuldades de aprendizagem advêm de diversos fatores, podendo atingir grande parte dos alunos. Isso representa um desafio que precisa ser superado no âmbito escolar. Dessa forma, tal discussão não pode ser ignorada no contexto educativo, devendo-se ampliar o investimento no debate teórico e metodológico de tais questões, visando assim a sua superação.

Ficou nítida a percepção do quanto é importante ter no meio escolar o incentivo e a iniciativa de fazer com que os alunos passem a ter um novo olhar para a leitura, para que a escola alcance todas as metas estabelecidas no que se refere ao processo de ensinoaprendizagem. Dessa forma, a intervenção pedagógica deve ser no sentido de criar projetos, realizar oficinas pedagógicas com o intuito de prevenir e/ou até acabar com as dificuldades identificadas na instituição, ajudando os alunos a resolver situações problemas de forma mais significativa.

O incentivo à leitura também seria uma forma de estímulo para uma aprendizagem 
lúdica e atraente, contribuindo para amenizar ou até acabar com as dificuldades das crianças envolvidas. Destacam-se algumas queixas por parte dos professores em relação à presença de diversas dificuldades de aprendizagem, principalmente no que envolve a leitura, a interpretação e a compreensão das palavras, frases e textos. Foi possível perceber que os alunos, ao lerem ou escreverem, não conseguem interpretar de forma coerente fatos de sua própria realidade. Por isso, foi elaborada uma proposta de intervenção pedagógica visando oportunizar aos alunos a participação ativa em uma oficina de leitura e letramento, com jogos que envolvem leitura e escrita, objetivando acabar com a repetência dos mesmos ao priorizar a interação deles nas atividades propostas.

Portanto, a proposta colocada neste trabalho seria uma alternativa, dentre tantas outras já existentes, para amenizar a problemática. Ela deve ser aplicada na escola como um todo, uma vez que sua missão é garantir aos alunos que essa aprendizagem seja significativa para a vida deles.

\section{REFERÊNCIAS}

ANDRADE, M. M. Introdução à metodologia do trabalho cientifico. Elaboração de trabalhos na graduação. São Paulo: Atlas, 2001.

ASSIS, M. B. A. C. Aspectos afetivos do desempenho escolar: alguns processos inconscientes. Boletim da Associação Brasileira de Psicopedagogia, n. 20, p. 35- 48, 1990.

BARROS, A. J. S.; LEHFELD, N. A. S. Fundamentos de metodologia: um guia para a iniciação cientifica. 2. ed. São Paulo: Makron Books, 2000.

BOSSA, Nádia A. A psicopedagogia no Brasil: contribuições a partir da prática. Porto Alegre: Artmed, 2007.

CEEL/UFPE - Centro de Estudos em Educação e Linguagem da Universidade Federal de Pernambuco; MEC - Ministério da Educação. Jogos de Alfabetização. Pernambuco, 2009.

CEEL/UFPE - Centro de Estudos em Educação e Linguagem da Universidade Federal de Pernambuco; MEC - Ministério da Educação. Alfabetização e letramento: conceitos e relações. Pernambuco, 2007.

COELHO, M. T.; JOSÉ, E. A. Problemas de aprendizagem. 8. ed. São Paulo: Ática, 1996.

CARRAHER, T. N.; SCHLIEMANN, A. D. Fracasso escolar: uma questão social. Cadernos de pesquisa, n. 45, p.3-18, maio, 1983. 
. Na vida dez, na escola zero. São Paulo: Cortez Editora, 1989.

FONSECA, J. J. S. Metodologia da pesquisa científica. Fortaleza: UEC, 2002.

FREIRE, Paulo. Pedagogia da Esperança. São Paulo: Paz e Terra. 2000.

. Pedagogia da Autonomia: saberes necessários à pratica educativa. 29. ed. São Paulo: Paz e Terra, 2004.

GADOTTI. Moacir. Boniteza de um sonho: ensinar-e-aprender com sentido. Novo Hamburgo: Feevale, 2003.

GONÇAlveS, M. D. (2002). Concepções Científicas e Concepções Pessoais sobre o Conhecimento e Dificuldades de Aprendizagem. Disponível em: http://www.lispsi.pt/public/índex.htm. Acesso em: 14 jun. 2020.

LEITE, S. A. da S. O fracasso escolar no ensino de primeiro grau. Revista Brasileira de estudos Pedagógicos, v.69, n.163, p.510-540, setembro/dezembro, 1988.

KLEIMAN, Angela. Texto e Leitor: Aspectos Cognitivos da Leitura. 8. ed. Campinas: Pontes, 2002.

KIRK, S. A. Educating Exceptional Children. Boston: Houghton Mifflin, 1962.

MINAYO, M. C. S. et al. Pesquisa social. 22. ed. Petrópolis: Vozes, 2003.

NUNES, Terezinha. Dificuldades na aprendizagem da leitura: teoria e prática. 2. ed. São Paulo: Cortez, 2001.

OLIVEIRA, Vera Barros de. Jogos de regras e a resolução de problemas. 4. ed. Petrópolis, R. J: Vozes, 2010.

OKANO, Cynthia Barroso et al. Crianças com dificuldades escolares atendidas em programas de suporte psicopedagógico na escola: avaliação do auto conceito. Psicol. Reflex. Crit., 2004 vol.17, nº 1, p. 121-128.

PIAGET, J. Psicologia e Pedagogia. 2. ed. Rio de Janeiro: Forense, 1972.

PAIN, Sara. Diagnóstico e Tratamento dos Problemas de Aprendizagem. 4. ed. Porto Alegre: Artes Médicas, 1992.

SANTOS, Carla Cristina Pereira, et al. Dificuldades de Aprendizagem em Leitura e 
escrita nas series iniciais do ensino fundamental. Revista Cientifica em Educação a Distancia. 2009.

SIMÕES, Darcília M. P. Consideração sobre a fala e a escrita: Fonologia em nova chave. São Paulo: Parábola, 2006.

SOARES, M. B. Letramento - Um em três gêneros. Belo Horizonte: Ceale, Autêntica, 1998.

. Dimensões da não Aprendizagem. Curitiba, PR: IESEDE, 2012.

VEIGA, Ilma Passos Alencastro. Projeto Político Pedagógico da Escola: uma construção possível. Campinas: Papirus, 2009.

VYGOTSKY, Lev S. A formação social da mente. São Paulo: Martins Fontes, 1984.

\section{APÊNDICE A - Questionário de Perguntas (Professor)}

1-Qual a visão do professor sobre o processo de aquisição da leitura e da escrita?

2-Quais são as principais dificuldades de aprendizagem encontradas na leitura e na escrita?

3-Qual o papel do professor diante dessa dificuldade?

5-Quais os aspectos que devem ser observados no sujeito que apresenta dificuldade de aprendizagem?

\section{APÊNDICE B - Projeto desenvolvido na Escola Felipe Magalhães}

A Escola Felipe Magalhães, na qual foi realizada a pesquisa, pertence à área urbana do município de Jaboatão dos Guararapes, localizada no bairro de Candeias, zona sul de Pernambuco. Atualmente a escola tem 350 alunos matriculados com 08 turmas funcionando pela manhã e 08 turmas à tarde, com faixa etária dos alunos de 02 a 10 anos, atendendo a várias comunidades da redondeza.

A estrutura física atual é distribuída por dois prédios. Um prédio principal térreo, onde fica a administração da escola e o ensino da educação infantil e outro prédio onde fica o ensino fundamental I que foi inaugurado em 2018. A escola é composta por uma equipe de uma diretora, um vice-diretor, uma coordenadora, duas auxiliares, onze professores 
contratados, um cantineiro e dois auxiliares de serviços gerais.

A equipe gestora é formada por professores graduados em letras, educação física, pedagogia e pós-graduados, com especialização em educação especial, e a equipe de infraestrutura é formada por profissionais desde o nível fundamental incompleto até graduados. Possui um conselho de classe com participação ativa, em que são realizadas reuniões em busca de melhorias que minimizem as dificuldades, visand o o bem-estar de todos os envolvidos no processo de ensino e aprendizagem. A escola baseia sua prática educativa com vistas a buscar a superação dos obstáculos, desenvolvendo ações, projetos didáticos e de intervenção ao longo do ano letivo.

A partir da análise dos dados, percebeu-se que apesar da aceitação e qualificação da escola, existe certa insatisfação com o rendimento da turma do $2^{\circ}$ ano do ensino fundamental I, com relação à leitura e ao letramento. Assim, como proposta e indicação para tentar ajudar os alunos frente a essa problemática, fica como sugestão o incentivo e estímulo da família em ajudar a manter um momento de leitura em casa, para assim ampliar o repertório de vivências. $\mathrm{Na}$ escola, com a mediação do professor, deve-se investir nas dinâmicas e metodologias diferenciadas, como uma oficina de jogos de leitura e a construção de um caderno de texto, conforme explicado no modelo abaixo.

Lista de jogos de leitura e letramento para serem confeccionados e trabalhados na oficina realizada pelos alunos:

- $\quad$ Cubos com sílabas;

- Jogo da coesão e coerência;

- Jogo da roleta;

- $\quad$ Bingo silábico;

- Pião silábico;

- Tabela de leitura.

Os alunos confeccionarão os jogos e criarão as regras de cada jogo. Os jogos serão trabalhados com os alunos e, por último, apresentado em uma feira de conhecimento.

Regras para a produção do Caderno de Texto:

1- Antes de usar este caderno leia com atenção. Ele é de uso coletivo. Então, cuide muito bem dele e traga-o na data combinada para que outro colega possa levá-lo;

2- Cuidados que deveremos ter com as produções de textos:

- $\quad$ A letra bem feita para que qualquer pessoa possa ler;

- $\quad$ Procure ler e reler sempre o que escreveu; 
- Use letras maiúsculas ao iniciar frases e ao escrever nomes próprios;

- $\quad$ Faça parágrafo sempre que iniciar uma nova frase;

- Tenha organização e capricho;

- Use a criatividade nas suas histórias;

- Tendo dúvidas peça ajuda a um adulto;

- $\quad$ Leia as histórias dos seus amigos;

- $\quad$ Não risque as histórias deles;

- $\quad$ Não apague as histórias que foram feitas;

- $\quad$ Cuide com carinho do CADERNO;

- $\quad$ Agora é só soltar a imaginação e escrever! 


\title{
E-COMMERCE: DESAFIOS NA CAPTAÇÃO DE CLIENTES EM UMA LOJA D O SEGMENTO DE ESSÊNCIAS
}

https://dx.doi.org/10.48097/2674-8673.2021n5p06

Erivaldo Severino de Santana ${ }^{1}$

Suzany Pereira ${ }^{2}$

Arandi Maciel Campelo ${ }^{3}$

\section{RESUMO}

Este artigo tem como objetivo mostrar os desafios da captação e fidelização de clientes em uma empresa do ramo de essências. Este artigo aborda os tipos de e-commerce e suas modalidades, como também relata métodos e maneiras práticas de captar e fidelizar clientes de maneira que eles não só se satisfaçam, mas fiquem encantados. Este trabalho inclui pesquisa sobre redes sociais como ferramenta de e-commerce. O campo investigativo foi a loja La Bella Essenza, sendo aplicado um questionário semiaberto, em 2020. O referencial teórico teve como principal balizador Fagundes (2009). Este trabalho demonstra como as redes sociais se tornaram uma arma indispensável nos dias de hoje para quem vende pela internet.

Palavras-chave: Redes Sociais. Captação e fidelização de clientes. E-commerce.

Data de submissão: $25 / 02 / 2021$

Data de aprovação: 29/03/2021

\begin{abstract}
This article aims to show the challenges of attracting and retaining customers in a company in the field of essences. This article discusses the types of e-commerce and its modalities, as well as reports methods and practical ways to attract and retain customers so that they are not only satisfied, but also delighted. This work includes research on social networks as an ecommerce tool. The investigative field was the La Bella Essenza store, using a semi-open questionnaire, in 2020. The theoretical framework was based on Fagundes (2009). This work

1 Estudante do curso de Administração da Faculdade Metropolitana da Grande Recife.

E-mail: juniofb9@gmail.com

2 Estudante do curso de Administração da Faculdade Metropolitana da Grande Recife.

E-mail: suzannyfenix30@gmail.com

3 Orientador: Doutor em Educação - Universidade Federal de Pernambuco; Administrador - Universidade de Pernambuco - FCAP/UPE; Mestre em Planificación y Gestion Organizacional - Universidad Autonoma de Madrid / Espanha; Mestre em Dirección y Organización de Hospitales y Servicios de Salud - Universidad Politécnica de Valencia / Espanha; Especialista em Marketing - FCAP/UPE; Consultor em Sistemas Organizacionais, desde 1984; Professor e Diretor Acadêmico da Faculdade Metropolitana da Grande Recife. E-mail: arandi.campelo@globo.com
\end{abstract}


demonstrates how social networks have become an indispensable weapon nowadays for those who sell over the internet.

Keywords: Social Networks. Attracting and retaining customers. E-commerce.

\section{INTRODUÇÃO}

Nesse novo cenário em que vivemos empresas de vários segmentos viram oportunidades de expandirem seus negócios utilizando o e-commerce e suas várias modalidades. Com a expansão do comércio eletrônico muitas empresas precisaram desenvolver novas estratégias para conquistar novos clientes e fidelizar os já existentes. A satisfação dos usuários do e-commerce passou a ser fator determinante de sucesso.

A pesquisa de campo foi realizada na empresa La Bella Essenza, uma distribuidora localizada em Jaboatão dos Guararapes. O tema escolhido é de grande importância para demostrar a dependência que a internet traz ao empreendedor, por se tratar de uma poderosa aliada ao empreendimento no e-commerce e nas redes sociais, refletindo na captação e fidelização de clientes.

\section{REFERENCIAL TEÓRICO}

Este trabalho teve com principal balizador Fagundes (2009), embora tenham sido utilizados outros autores para o embasamento deste artigo, como Kotler (2017) e Gonçalves (2007).

\section{E-commerce}

O comércio eletrônico é definido como qualquer transação comercial que envolva os processos de negócios através de um ambiente eletrônico, por exemplo, a internet. O fundador da rede americana Sears, Richard Sears, começou seu negócio vendendo relógios através de telegramas para seus colegas na época em que era agente de estação de trem, no final do século 19, com uma margem muito pequena de lucro.

O comércio eletrônico, como conhecemos hoje, iniciou no final da década de 1960. Desde 1993, novas tecnologias permitem às empresas realizar funções e-business ${ }^{4}$ com maior eficiência, rapidez e menores custos do que jamais foi possível.

4 E-business, acrônimo do inglês Electronic Business (negócio eletrônico), é o termo que se utiliza para identificar os negócios efetuados por meios eletrônicos, geralmente na internet. 
Segundo Fagundes (2009):

O comércio eletrônico através da internet é o ramo de atividade econômica que mais cresce no mundo. As jovens empresas que ingressam no comércio on-line têm atraído o maior número de investidores do mercado de ações, aumentando o valor de mercado de forma alucinante. (FAGUNDES, 2009, p. 01).

E-commerce ${ }^{5}$ é todo o comércio realizado através de meios eletrônicos. É a compra e venda de bens e serviços ou a transmissão de fundos ou dados, através de uma rede eletrônica, principalmente a internet.

Para se entender a principal diferença entre e-business e e-commerce é que o segundo é como um subproduto do primeiro. E-business aborda todo o processo de negociação que uma empresa faz pela internet e e-commerce as transações comerciais de bens e serviços on-line. Então, todo e-commerce é um exemplo de e-business.

O e-commerce surgiu em 1970 com a EDI e EFT ${ }^{6}$ fazendo transferências de valores entre pessoas e empresas, mas foi com a internet que ganhou força e ficou disponível para todas as pessoas.

Os benefícios do comércio eletrônico incluem disponibilidade 24 horas, velocidade de acesso, ampla disponibilidade de bens e serviços para o consumidor, fácil acessibilidade e alcance internacional. (GONÇALVES, 2007).

Enquanto os compradores em uma loja física podem ser mais lentos pelas multidões, os sites de comércio eletrônico são executados rapidamente, o que é determinado por considerações de computação e largura de banda no dispositivo do consumidor e no site de comércio eletrônico.

A esse respeito, conforme cita Campano (2010):

Iniciar um negócio on-line é bem simples, se comparado a um negócio tradicional. Não exige muito dinheiro ou tempo para iniciar e as formas de se fazer dinheiro com um negócio on-line são muitas: vendendo produtos reais ou digitais, criando websites ou logotipos para empresas, criando um blog, criando comunidades interessadas em um certo tema etc. De fato, muitas pessoas fizeram e estão fazendo muito dinheiro com seu negócio online. (CAMPANO, 2010, p. 01).

5 E-commerce (ou "comércio eletrônico" em português) é uma modalidade de comércio em que os negócios e transações financeiras são realizadas via dispositivos e plataformas eletrônicas, como computadores, tablets e smartphones.

6 Emotional Freedom Techniques, ou Técnica de Libertação Emocional e Electronic Data Interchange, ou, em português, Intercâmbio Eletrônico de Dados. 
Há algum tempo atrás não havia muitos outros meios de realizar compras se não fosse de forma física, ou seja, sair do conforto de casa e ir até a loja comprar o produto. Aqui no Brasil, por exemplo, o comércio eletrônico tem menos de duas décadas de existência.

A evolução desse tipo de comércio esteve sempre muito interligada com o desenvolvimento da internet. Assim, com a popularização da internet (por volta da segunda metade da década de 90), o comércio eletrônico começou a operar semelhantemente como é hoje. Nessa época, então, o comércio eletrônico deixou de ser tendência e se tornou uma realidade sólida para os que gostam de facilidade e praticidade na hora de comprar alguma mercadoria ou produto.

É comum que quem ainda não tenha boa prática com a internet esteja cercado de dúvidas sobre como funcionam os tipos de comércio eletrônico. Quando pensamos em ecommerce logo vem em mente um site que vende produtos para um consumidor final. Porém, há muitas empresas que vendem para outras empresas e usam a internet como estratégia comercial. (CARDOSO, 2012).

Hoje, a TV digital, por exemplo, conta com muitos recursos que permitem uma maior interatividade do telespectador e que novos campos sejam explorados. O t-commerce oferece uma nova forma de receitas financeiras para emissoras, serviços de streaming, marcas etc.

\section{Redes sociais como ferramentas do e-commerce}

Quando se fala em estratégias de marketing digital para e-commerce, uma das mais lembradas é o marketing para redes sociais que hoje faz parte de nosso cotidiano. É por meio delas que as pessoas se comunicam, se atualizam, fazem trocas, vendem, entre outras diversas atividades. Hoje grande parte das lojas virtuais já tem sua página no Facebook, Instagram, YouTube ou em outras mídias sociais. E mesmo aquelas que não têm perfis nessas plataformas também estão presentes nesse contexto. Com as redes sociais, eles esperam muito mais de uma empresa do que apenas comprar e vender. Por esse motivo é preciso ter diálogo, conteúdo, confiança e até mesmo descontração. São detalhes que humanizam mais a relação entre marcas e consumidores, criando diferenciais para que o público não seja convencido apenas por preço ou conveniência. (KIYOSAKI, 2013).

O uso das redes sociais para o e-commerce reforça a importância dessas ferramentas na atração de clientes. A loja virtual pode conhecer melhor o seu público-alvo, suas preferências e necessidades para, então, se aproximar do cliente que tem interesse nos produtos ou 
serviços. Outro benefício importante, além de atrair clientes, é o poder de segmentação das redes, especialmente nas plataformas de anúncios. Manter interação exclusivamente comercial é algo que raramente seduz e fideliza os clientes. Com as redes sociais, eles esperam bem mais da empresa do que apenas comprar.

Esses detalhes tornam a relação com os consumidores mais estreita e humanizada, criando um diferencial para o público. Um perfil na web que proporciona discussões interessantes e que compartilha conteúdos relevantes para os seguidores, ajudando a melhorar a credibilidade da empresa.

Esse tipo de comportamento aumenta também o engajamento e a educação do cliente. Certamente você já viu várias promoções de produtos nas redes sociais de lojas virtuais que querem chamar a atenção do público. Essa técnica, quando bem aplicada, pode gerar resultados positivos nas vendas, além de tornar a marca ainda mais conhecida no mercado. Sem dúvida, uma característica comum dessas redes é o custo reduzido, quando comparado aos meios tradicionais de marketing, como propaganda em mídias de massa como a televisão. Além disso, o investimento pode ser flexível, já que o e-commerce pode escolher em qual ação ou campanha quer investir mais.

Existem tantas opções de mídias sociais atualmente que pode ser um pouco difícil escolher em qual estar presente.

Facebook - Essa é a maior rede social do mundo e, por isso, muito importante para o comércio eletrônico. Tem aplicação bem ampla, com postagens de conteúdos em textos, imagens e vídeos, permitindo uma conexão próxima com o público. Além disso, ela oferece a opção de anúncios publicitários pagos, veiculados dentro da plataforma e de outras redes do mesmo grupo, como o Instagram.

Instagram - O foco do Instagram está voltado para o aspecto visual. A rede é usada para compartilhamento de imagens e vídeos, com grande potencial de engajamento do público. É a mídia ideal para apresentar novos produtos aos consumidores.

YouTube - Plataforma mais popular de veiculação e compartilhamento de vídeos, o YouTube consegue obter grande participação do público por meio dos seus conteúdos, sobretudo devido a forte presença de influenciadores digitais. Nos últimos anos a rede ganhou muito destaque, pois os conteúdos em vídeos viraram tendência.

LinkedIn - É uma rede social empresarial, voltada para um público que deseja estabelecer relações profissionais. Em geral, a plataforma atrai usuários mais formais, mas 
deve seguir a cultura da empresa e apresentar conteúdos bem segmentados. Tudo isso por meio de conteúdos como textos, infográficos e vídeos que entregam informações relevantes e constroem um relacionamento com os consumidores.

Estar presente em todas elas pode ser um pouco complicado e gerar um trabalho desnecessário e improdutivo. Portanto, deve-se escolher e ser ativo nas redes mais adequadas a cada loja e público. O perfil traçado do cliente ajudará a escolher a plataforma ideal. Por fim, fica evidente a importância de utilizar as redes sociais para e-commerce, já que elas são os principais canais de interação com os consumidores no mundo digital e uma das melhores formas de atrair novos clientes.

\section{Captação e fidelização de clientes}

Conquistar a clientela é uma das tarefas mais importantes para a sobrevivência de qualquer negócio. Uma boa alternativa é criar propostas satisfatórias em busca de reter clientes para manter sempre a empresa em crescimento constante, criando inúmeras formas de satisfazê-los com o intuito de captar e cativar cada vez mais. As empresas têm que adotar métodos de captação e fidelização através de pesquisas relacionadas ao nível de satisfação de produtos e serviços; ao atendimento; sobre como está a visualização dos produtos da empresa em sites, revistas, outdoors etc.; como está sendo a experiência de utilizar os produtos ou serviços prestados no dia a dia; e buscar saber dos clientes sua opinião sobre novos produtos.

Para Kotler (2017):

O valor entregue ao cliente é a diferença entre o valor total para o cliente e o custo total para o cliente. $\mathrm{O}$ valor total para o cliente é o conjunto de benefícios que os clientes esperam de um determinado produto ou serviço. O custo total para o cliente é o conjunto de custos em que os clientes consumidores esperam incorrer para avaliar, obter, utilizar e descartar um produto ou serviço. (KOTLER, 2017, p. 01).

Não basta apenas criar uma proposta de valor, ela tem que ser acompanhada e entregue. Essa estratégia envolve toda experiência que os clientes obterão ao interagir com os serviços ou produtos.

$\mathrm{O}$ valor prometido pela organização deve corresponder às expectativas dos clientes, incluindo comunicação, canais que foram utilizados para que as informações cheguem até eles e todo caminho percorrido pelo cliente até obter o que procura, conforme o que lhe foi prometido. 
Fidelizar clientes é uma tarefa que requer atenção da empresa. É nesse ponto que muitas delas não se atentam, pois exige esforço, tempo, dedicação, recursos pessoais e financeiros para as campanhas de fidelização dar certo.

Para Kotler (2017) existem gradações nessa fidelidade, dividida em quatro categorias que ele chama de status.

- Clientes fiéis convictos: são aqueles consumidores que têm o hábito de comprar sempre da mesma marca.

- Clientes fiéis divididos: um tipo de consumidor que é fiel a mais de uma marca, podendo ser 2 ou 3.

- Clientes fiéis inconstantes: estão mudando de marca a todo o momento.

- Clientes infiéis: não têm preferência ou fidelidade por marca alguma.

(KOTLER, 2017, p. 01)

No questionamento descrito por Kotler (2017), considerando essa classificação, ele recomenda que as organizações façam um levantamento analítico de seus clientes fiéis convictos para estudarem seus pontos fortes e analisar o comportamento dos clientes fiéis divididos, criando meios para torná-los convictos da marca. Por último, analisar os clientes que estão mudando de marca o tempo todo e aqueles que não têm fidelidade por marca nenhuma, que é o caso dos clientes fiéis inconstantes e os infiéis, buscando entender por que agem de tal forma.

Kotler (2017) cita que para o negócio dar certo já não basta simplesmente satisfazer o cliente. É preciso encantá-lo. A empresa tem que ter por base essa ideologia, além de técnicas para captar e fidelizar sua clientela e assim se sobressair perante a concorrência.

A noção de fidelizar clientes está centrada na ideia de fazer com que eles se tornem clientes engajados, capazes de interagir com a marca nas redes sociais, interessados em novos produtos e campanhas e, claro, dispostos a comprar na sua loja por várias vezes.

Cardoso (2012) afirma que conquistar a fidelidade do cliente é, cada vez mais, o desafio das empresas, preocupadas não apenas com a competitividade, mas com a própria sobrevivência no mercado. Alcançar esse objetivo requer uma série de cuidados.

Em princípio, convém considerar a fidelidade como um tipo de comportamento complexo. Seja no campo das relações afetivas ou comerciais, fidelidade significa, em síntese, a confirmação de uma escolha, opção exclusiva por algo ou alguém e permanência dessa opção em um determinado tempo. 


\section{METODOLOGIA}

Vale destacar que este artigo tem como objetivo geral analisar as técnicas usadas pela loja La Bella Essenza na qualidade do atendimento, através das redes sociais como ferramenta do e-commerce, atuando na captação e fidelização de clientes.

O universo do campo pesquisado é composto por 4 gestores, cujos critérios para esta definição estão baseados nos cargos de liderança do setor administrativo. Destes, apenas 1 foi entrevistado.

A pesquisa que orientou este artigo foi de natureza bibliográfica, de campo e aplicada.

\section{DESENVOLVIMENTO DA PESQUISA DE CAMPO}

O campo investigativo deste artigo foi a loja La Bella Essenza, uma empresa do ramo de essências, localizada na cidade de Jaboatão dos Guararapes, Pernambuco.

$\mathrm{O}$ instrumento de campo utilizado na pesquisa foi um questionário semiaberto, constante no apêndice deste trabalho.

1. A empresa utiliza as redes sociais como marketing e comunicação para atrair clientes? Quais?

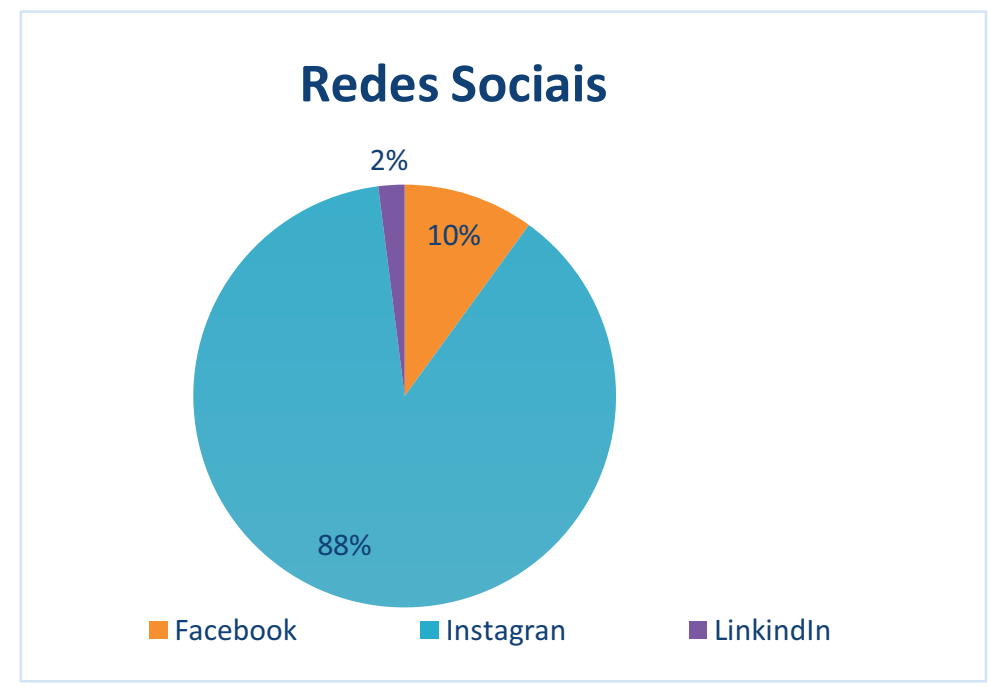

As respostas obtidas estão de acordo quando se fala sobre estratégia de marketing. Hoje, as redes sociais fazem parte do nosso cotidiano. Com o avanço na tecnologia e melhor acesso à internet existe uma facilidade muito grande na hora de conquistar o público-alvo através destas ferramentas. 
2. A empresa oferece promoções aos clientes? Essas promoções levam à fidelização?

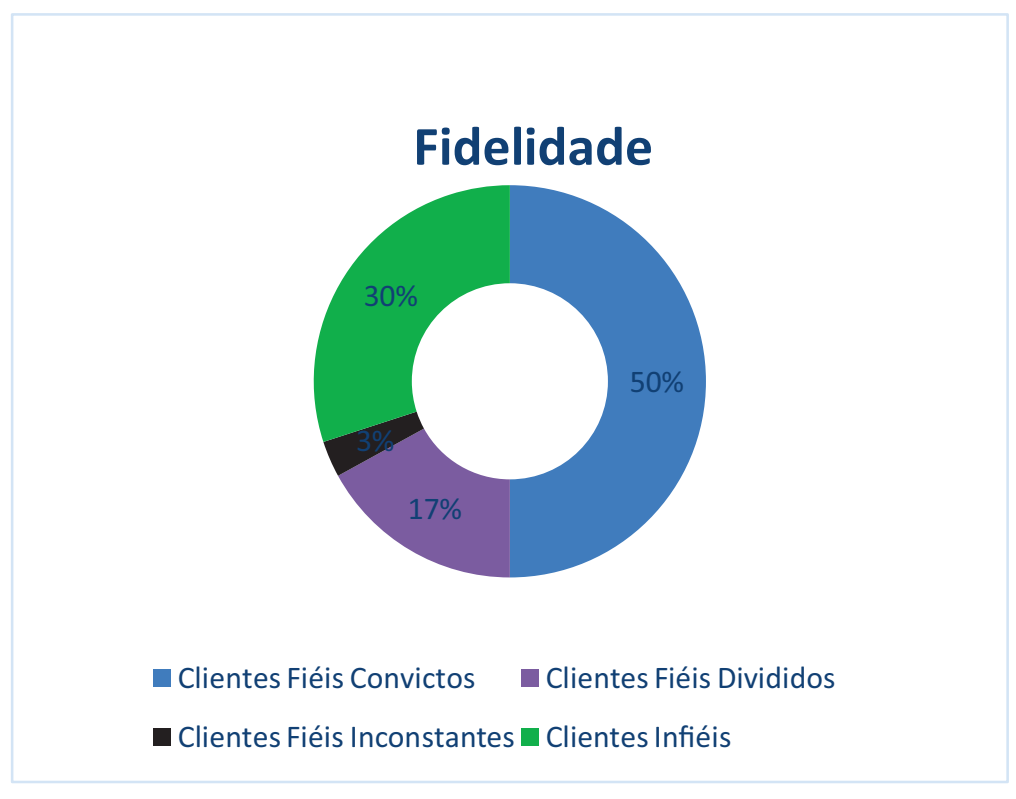

As repostas obtidas estão de acordo com as considerações de Kotler (2017) sobre os tipos de clientes.

3. A empresa tem política de fidelização de cliente?

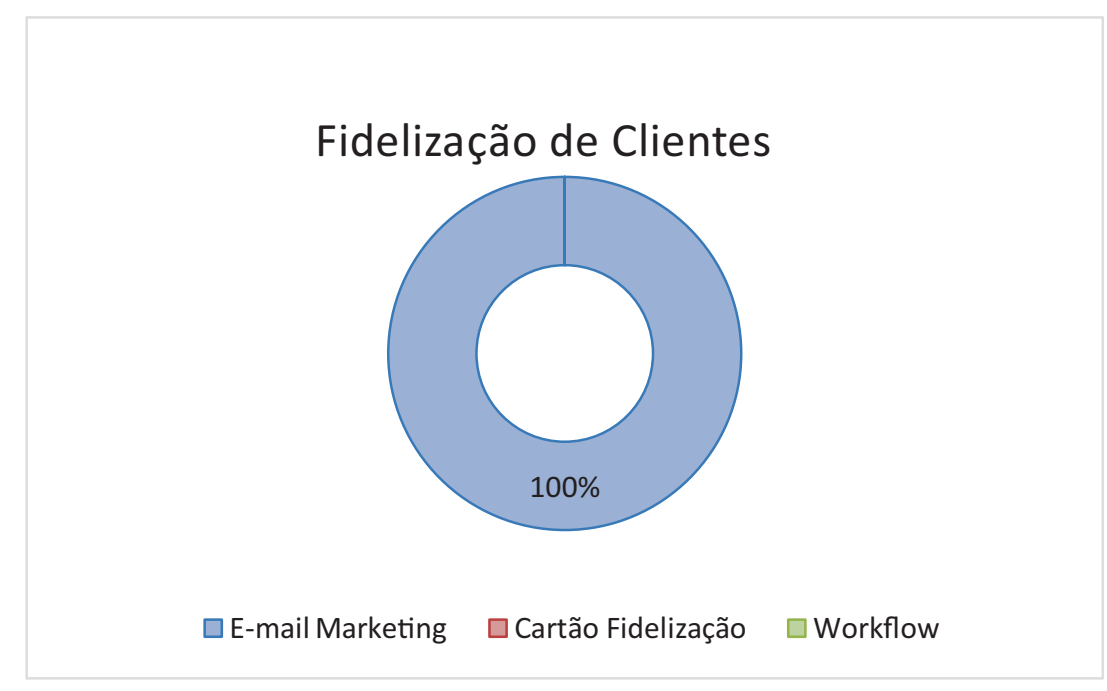

Apesar das várias maneiras de fidelização, a empresa utiliza apenas o e-mail marketing como forma de fidelizar seus clientes. 
4. Quais formas de pagamento a sua empresa utiliza?

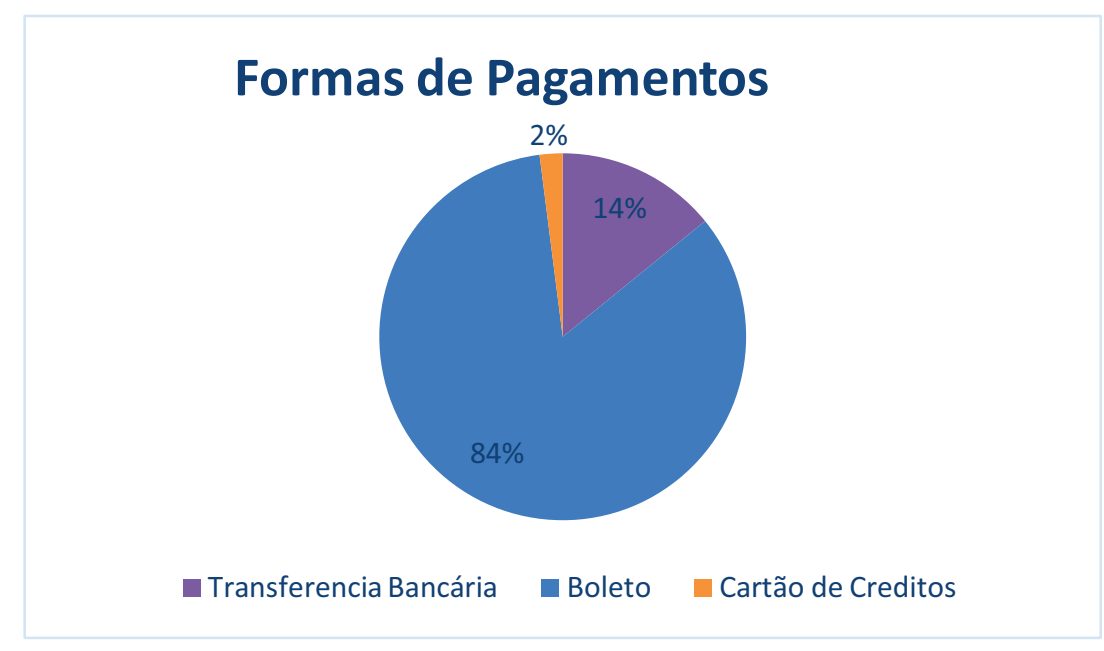

Sabemos que o boleto não é umas das formas mais seguras de pagamentos, porém, na maioria das vezes, é a única opção para poder atender ao cliente que não tem acesso ao cartão de crédito ou débito, ou até mesmo não ter limite no cartão. Apesar de poder existir inadimplências e prejuízos, o boleto é a forma de pagamento mais usada na empresa.

5. Quais tipos de logística a empresa aplica?

\section{Tipos de Logística}

- Produção

- Suprimentos

reverso

- Distribuição

Embora a empresa tenha respondido que trabalha apenas focada na logística de distribuição, observamos também atuação da logística de suprimentos, pelo fato deles também proporcionar não só a distribuição de material, mas conter no pacote qualidade, preço, e manter sempre estoque para seus clientes. 
6. Qual o número de visitantes mensais? E desses, quantos fidelizam o atendimento?

Ações nos seus anúncios

Os cliques no anúncio resultam em visitas ao seu site ou página de destino ou em chamadas para sua empresa. Quando alguém clica no seu anúncio, significa que ele está chamando a atenção e que as pessoas querem saber mais sobre sua empresa e o que você oferece.

Nós cobramos pelos cliques.

Origem dos cliques no seu anúncio

Para levar mais clientes até você pelo menor custo, exibimos seus anúncios no Google e nos sites parceiros. Saiba mais

\section{9}

Cliques
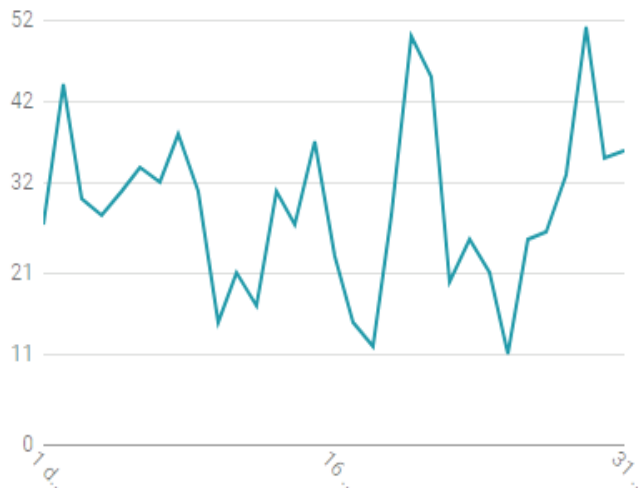

) 410

cliques no Google

410 Pesquisa Google

0 YouTube

$<$ TODAS AS CAMPANHAS

Essências Concentradas - La Bella Distr. Aromaty

ATIVA $\checkmark$

Anúncios exibidos há 2 horas

Último mês -

RS 316,54 Gastos do mês passado

@

36,9 mil

Impressões

A frequência com que seus

anúncios foram exibidos

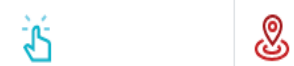

899

Cliques

Açoes de local

Açőes nos seus anúncios Açōes que mostram

intenção de visitar
हู)

42

Chamadas

Chamadas para sua

empresa
.0

\section{7}

Conversões

Açőes no seu site

relacionadas a anúncios

VER DETALHES DO DESEMPENHO

A média mensal de visitas (site e redes sociais) é de 899 acessos. 5\% é o retorno eficiente e convertido em vendas. Diante das pesquisas pode-se afirmar que esses clientes são aqueles que apenas buscam preços e não se importam com qualidade, bom atendimento ou assistência que a empresa pode oferecer. 


\section{CONSIDERAÇÕES FINAIS}

O foco deste artigo é demonstrar os desafios e a importância da ferramenta do ecommerce para a captação e fidelização de clientes no segmento de essências. É inegável que muitas empresas têm dificuldades ao usar essa ferramenta pelo fato de não buscar se aprimorar e mediante esse motivo sofrem frente às demais.

As redes sociais, hoje, estão se tornando um instrumento de proporções inimagináveis para auxiliar empresas que buscam esse tipo de segmento. É muito importante se esforçar ao máximo e trabalhar em cima de uma estratégia de captação de clientes bem definida para que depois eles se tornem leais à empresa, uma vez que as atenções da economia mundial estão voltadas para estabelecer conexão entre o mundo real e o virtual. Com o surgimento da internet e as mudanças no perfil de compra dos consumidores muitas empresas perceberam oportunidades de expandirem seus negócios.

Neste contexto, os profissionais de marketing adequaram as teorias fundamentais do comércio real para atenderem as necessidades deste novo mercado virtual, buscando consolidar um atendimento individualizado e contínuo. $\mathrm{O}$ foco no relacionamento com o cliente passou a ser a garantia da entrega do produto, fortalecendo a área de logística que no mercado virtual é a certeza do sucesso.

Diane do exposto, é recomendável que a empresa do ramo de essência La Bella Essenza siga as dicas deste material de estudo, proposto em formato de artigo científico, com o intuito de alavancar e ampliar seu leque de conhecimento no uso de suas estratégias de captação e fidelização de clientes. Cada autor citado, cada referência, cada pesquisa feita, fará com que a empresa possa tomar decisões melhores nas escolhas de suas estratégias, facilitando a compreensão sobre o assunto com metodologias fáceis de serem aplicadas no dia a dia.

Sugere-se, então, a importância de um bom atendimento desde a abordagem inicial. O profissional tem que saber ouvir seu cliente e entender o que ele precisa. Através do sucesso deste contato, pode-se afirmar que foi criada uma relação entre o cliente e a empresa, que o negócio foi fechado, podendo assim torná-lo fidelizado.

\section{REFERÊNCIAS}

CAMPANO, Jefeson. Como criar seu negocio online. 3. ed. São Paulo: JM Digital, 2010. 
CARDOSO, Cármen. Fidelização de clientes. Disponível em: http://www.notitia.truenet.com.br. Acesso em: 05 de jun. 2012.

FAGUNDES, Eduardo. O que é o e-commerce. 2009. Disponível em: https://efagundes.com/artigos/o-que-e-e-commerce/\#content. Acesso em: 02 jul. 2020.

GONÇALVES, Helmer José. Fidelização de Clientes. Monografia. 2007. Programa de Pósgraduação da Escola de Administração da UFRGS. Disponível em: https://lume.ufrgs.br/bitstream/handle/10183/14026/000649603.pdf. Acesso em: 11 jul. 2020.

KIYOSAKI, Robert T. Escola de Negócios. Rio de Janeiro: Elsevier, 2013.

KOTLER, Philip. Marketing 4.0. Rio de Janeiro: Sextante, 2017.

PAULILlO, Julio. AGENDOR BLOG. O custo total para o cliente. Disponível em: https://www.agendor.com.br/blog/. Acesso em: 03 jul. 2020.

\section{APÊNDICE A - Modelo de questionário semiaberto aplicado}

1. A empresa tem política de fidelização de clientes?

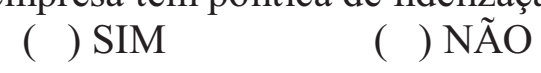

Se sim, quais são utilizadas:
a) E-mail marketing
b) Cartão para fidelização de cliente
c) Workflow
d) Outras:

2. A empresa utiliza as redes sociais como marketing e comunicação para atrair clientes?

$$
\text { ( ) SIM ( ) NÃO }
$$

Se sim, quais são utilizadas:
a) Instagram
b) Facebook
c) Youtube
d) Outras: LinkedIn

3. Quais as vantagens e desvantagens da rede social?

R: O número de captação de clientes é uma das vantagens, mas um grande percentual desta captação representa atendimentos que são descartados. Outra vantagem é a rápida 
pulverização de lançamento ou oferta. A desvantagem ocorre quando não há um cálculo preciso para suprir a demanda ou logística.

4. Qual é a sua abordagem para dar continuidade ao atendimento com o cliente da rede social?

R: Nossas campanhas possuem uma linguagem objetiva e direcionada ao públicoalvo. Indicamos a opção de conhecer o nosso site onde encontrará acesso ao mix de itens e informações relevantes ao processo de fabricação, ou ligar diretamente para a empresa e receber estas informações por e-mail, esclarecendo todas as dúvidas.

5. Qual é o papel das mídias sociais no seu processo de vendas?

R: O foco é a captação de clientes e pulverização da marca. A velocidade em chegar aos lugares mais distantes é representativo e lucrativo. Estar na rede social com campanhas agradáveis e objetivas também muda a imagem de nossa empresa, tornandoa mais próxima e amigável.

6. Quando você deve parar de trabalhar um cliente?

R: O conceito cliente para nós é: o individuo empreendedor ou a empresa produtora que usa uma marca concorrente ou irá utilizar nossos itens em novo projeto. $\mathrm{O}$ descarte ocorre na seleção quando a PF ou PJ não tem aplicação de nossos itens, ou se não se enquadra na política comercial de atendimento de venda em atacado. Já sendo um cliente, ele próprio se descarta quando se torna inadimplente ou opta por padrões abaixo de nossa qualidade.

7. A empresa oferece promoções aos clientes? Essas promoções levam a fidelização?
( ) SIM
( ) NÃO

R: As promoções visam desovar estoques ou venda rápida de lançamentos. A fidelização não ocorre com uma oferta e sim com os resultados obtidos após a aquisição do item. As promoções são praticamente uma forma de entrar na empresa alvo a fim de obter proximidade de atendimento.

8. Quais tipos de logística a empresa aplica?
a) Produção
b) Suprimentos
c) Reversa
d) Distribuição

9. Quais formas de pagamento a sua empresa utiliza?
a) Depósito
b) Boleto
c) Cartão de Crédito
d) Todas Acima 
10. Qual a frequência que a empresa posta novos conteúdos? Tem retorno considerável?

R: Diariamente temos conteúdos novos na rede social. Sim, são lucrativos e eficientes.

11. Qual o número de visitantes mensais? E desses quantos fidelizam o atendimento?

R: A média mensal de visitas (Site e Redes Sociais) é de $899.5 \%$ dos acessos têm retorno eficiente e convertido em venda.

12. Como está o relacionamento com os seguidores nas mídias sociais? Você responde as mensagens privadas e os comentários públicos de seus fãs na rede social usada?

R: Nenhuma pergunta ou elogio fica sem resposta. Por termos um produto de processo industrial e sendo nosso atendimento focado na Pessoa Jurídica ou empreendedores raramente há trocas de mensagens. 


\title{
EDUCAÇÃO AMBIENTAL NA EDUCAÇÃO INFANTIL
}

\author{
https://dx.doi.org/10.48097/2674-8673.2021n5p07
}

\author{
Rafaela do Nascimento Rocha ${ }^{1}$ \\ Sílvia Cavalcanti ${ }^{2}$
}

\section{RESUMO}

O presente artigo tem por finalidade analisar a relação da Educação Ambiental e a Educação Infantil, trazendo uma breve apresentação histórica do tema abordado, além de discutir as leis que regem a educação ambiental no país, com base no antigo referencial curricular nacional (no eixo natureza e sociedade), na Base Nacional Comum Curricular e nos conceitos e princípios da educação ambiental. São abordadas nesta pesquisa algumas dificuldades apresentadas pelos professores, através de questionário realizado, como também algumas sugestões de propostas para incentivos do governo, visando à qualificação dos docentes na área ambiental para assim gerar mais abertura para a construção de uma consciência ambiental em que os alunos comecem a desenvolver e realizar atitudes sustentáveis dentro e fora da escola.

Palavras-chave: Educação ambiental. Educação infantil. Consciência ambiental.

Data de submissão: 18/03/2021

Data de aprovação: 29/04/2021

\begin{abstract}
The purpose of this article is to analyze the relationship between Environmental Education and Early Childhood Education, bringing a brief historical presentation of the topic addressed, in addition to discussing the laws that govern environmental education in the country, based on the old national curriculum framework (in the nature axis) and society), in the Common National Curricular Base and in the concepts and principles of environmental education. In this research, some difficulties presented by the teachers are addressed, through a questionnaire, as well as some suggestions for proposals for government incentives, aiming at the qualification of the teachers in the environmental area, thus generating more openness for the construction of an environmental awareness in which the students start to develop and carry out sustainable attitudes inside and outside the school.
\end{abstract}

Keywords: Environmental education. Child education. Environmental awareness.

\footnotetext{
${ }^{1}$ Graduanda do Curso de Bacharelado em Pedagogia da Faculdade Metropolitana da Grande Recife.

E-mail: rafaelarocha_nascimento@hotmail.com

2 Professora orientadora do Curso de Bacharelado em Pedagogia da FMGR.

E-mail: silvinharca@hotmail.com
} 


\section{INTRODUÇÃO}

Ao longo do curso de Pedagogia é possível vivenciar diversas situações de ausência de cuidado com o meio ambiente em instituições de ensino, tanto na rede pública como na rede privada. Neste percurso foi observada a necessidade de uma educação ambiental mais presente no cotidiano escolar, principalmente na educação infantil.

Para Naná Mininni (2001), a educação ambiental deve proporcionar às pessoas uma compreensão crítica e global do ambiente. Esclarecer valores e desenvolver atitudes que thes permitam adotar uma posição consciente e participativa dos recursos naturais para a melhoria da qualidade de vida e a eliminação da pobreza extrema e do consumismo desenfreado.

As questões ambientais estão cada vez mais presentes no dia a dia da sociedade. Desta forma, a educação ambiental é fundamental em todas as etapas da educação, especialmente na educação infantil, já que é neste momento que as crianças começam a relacionar-se com a ideia de sociedade e aprende os valores que servirão como base para a vida.

O que mais chamou a atenção foi a falta de informação dos alunos das séries mais avançadas. Este foi o ponto de partida para abordar o presente tema, considerado de extrema necessidade dentro da área da educação, pois buscamos formar indivíduos responsáveis e preocupados com os problemas ambientais e com a preservação dos recursos naturais.

São abordados alguns autores como Moacir Gadotti (2000), Genebaldo Dias (2004) e Heloisa Penteado (2010), que defendem a educação ambiental como disciplina que deve estar presente no cotidiano escolar.

\section{FUNDAMENTAÇÃO TEÓRICA}

Ao pensar em educação ambiental na pré-escola, devemos levar em consideração vários aspectos importantes, como por exemplo, a ausência dessa disciplina no contexto da educação infantil e a falta de formação para os professores nesta área.

A Lei de Diretrizes e Bases da Educação Nacional (LDB - 9394/96), em seu artigo 29, garante que a finalidade da educação infantil é de desenvolver na criança seus elementos físico, psicológico, intelectual e social.

A educação infantil seguia o referencial curricular nacional para a educação infantil de 1998 até 2019, criado com o objetivo de nortear os educadores sobre os eixos que deveriam ser seguidos para a educação infantil.

Dias (1992) afirma que o despreparo e a falta de informações sobre a educação ambiental faz com que o conceito desta área seja equivocado, priorizando problemas ambientais globais, quando deveriam ser discutidos os seus princípios e seus valores e 
atitudes voltadas para a conservação do meio ambiente. Por isto, destaca em sua obra a importância da educação ambiental escolar para a construção de mudanças de valores e atitudes sustentáveis. Para alcançar esse objetivo deve-se utilizar uma pedagogia crítica e libertadora, como a de Paulo Freire.

Já Penteado (2010) afirma que para se ter uma educação ambiental de qualidade é preciso manter os conhecimentos e experiências de cada professor, para organizar uma nova ação educativa que envolva a educação ambiental em todos os campos de experiência, de modo que haja uma construção de uma "consciência ambiental" por parte dos educandos e educadores. De acordo com Penteado (2010, p. 59) "o desenvolvimento da cidadania e a formação da consciência ambiental têm na escola um local adequado para sua realização através de um ensino ativo e participativo".

Gadotti (2013, p. 79), em sua obra Pedagogia da Terra, trata da ecopedagogia. A seu ver “é uma pedagogia de promoção da aprendizagem" que pretende desenvolver um novo olhar sobre a educação.

Neste sentido, a ecopedadogia busca promover a aprendizagem sustentável, não apenas para o bom funcionamento do meio ambiente como também buscar fazer com que os indivíduos formem pensamentos críticos sobre a convivência em sociedade no cotidiano dentro e fora da escola.

A educação ambiental acredita em um processo libertador, em uma sociedade mais justa, baseada no respeito às várias formas de vida que há no planeta. Como diz Gadotti (2000, p. 12), "Precisamos de uma pedagogia da terra, apropriada para este momento de reconstrução paradigmática apropriada à cultura da sustentabilidade e da paz”.

Como podemos perceber com os estudos citados acima, a educação ambiental é de grande importância para o desenvolvimento de cidadãos críticos, levando os indivíduos a refletirem suas práticas no cotidiano de forma sustentável.

\section{BREVE HISTÓRIA DA EDUCAÇÃO AMBIENTAL}

Os problemas ambientais provocados pelos seres humanos decorrem do uso indevido do meio ambiente na obtenção dos recursos necessários à produção dos bens e serviços que eles precisam. Com uma boa base de conhecimento sobre o meio ambiente é possível modificar esse quadro de devastação dos recursos naturais.

$\mathrm{Na}$ década de 50 as consequências dos desequilíbrios ambientais começam a ficar em evidência em episódios como a contaminação do ar, pelas fábricas, em Londres e Nova York; os casos de intoxicação por mercúrio em Minamata e Niigata, no Japão; a morte de aves pelo 
efeito DDT e, principalmente, a bomba atômica de Hiroshima. Os testes nucleares no oceano pacífico começaram a ganhar notoriedade e a serem percebidos como problemas ambientais importantes, primeiro pelas comunidades científicas e depois por parte da população dos países afetados. Já no Brasil, a educação ambiental começa a ser discutida a partir dos anos 60. O ambientalismo se fortaleceu ao aliar-se aos diferentes movimentos sociais deste período.

O primeiro passo que instigou a preocupação com a Educação Ambiental foi resultante de um livro de caráter literário chamado "Primavera Silenciosa", de Rachel Carson, em 1962. O livro alerta sobre os efeitos danosos de inúmeras ações humanas relativas ao meio ambiente.

Em 1968 surge o primeiro registro representativo da educação ambiental que ocorreu na academia de Lincei em Roma, composto por cientistas de vários países e que tinha o objetivo de discutir e propor soluções aos problemas ambientais que surgiram com o crescimento da população mundial.

Já em 1972 houve a conferência de Estocolmo, na Suécia, com a participação de 113 países. Esta conferência é considerada um marco histórico internacional, decisivo no despontar de políticas de gerenciamento ambiental, chamando a atenção do mundo para os problemas ambientais. A partir dela foi instituído o dia internacional do meio ambiente (5 de junho).

O marco seguinte foi em 1975, quando se deu o encontro internacional de educação ambiental de Belgrado. Nesse encontro foram formulados os princípios e orientações para o Programa Internacional de Educação Ambiental (PIEA). Neste mesmo encontro foi elaborada a Carta de Belgrado, que veio a ser um dos mais importantes documentos sobre a questão ambiental e que trata, sobre uma nova ética global, de formas de desenvolvimento que beneficiem toda a humanidade.

A conferência de Tbilisi, considerada a primeira conferência intergovernamental sobre educação ambiental ocorreu no ano de 1977, organizada pela UNESCO, em cooperação com a PNUMA. Este encontro é considerado referência internacional para o desenvolvimento da educação ambiental. Um dos pontos discutidos foi o pressuposto da educação como forma de contribuir para a resolução de problemas ambientais. A conferência de Tbilise estabelece que a EA deve ser tratada como dinâmica, interativa, transformadora, participativa, abrangente e permanente. Nesta mesma ocasião foram traçados os objetivos a as estratégias a serem adotadas por todos os países, no que se refere à educação ambiental.

Em junho de 1992, no Rio de Janeiro, foi realizada a Conferência das Nações Unidas 
sobre meio ambiente e desenvolvimento (Rio-92), em que foi estabelecida uma proposta de ação para os próximos anos, denominada agenda 21. Este documento procurou assegurar o acesso universal da EA em todos os níveis da educação básica.

\section{CONCEITOS E PRINCÍPIOS DA EDUCAÇÃO AMBIENTAL}

A EA é um conceito ainda novo, que gera muitas discussões, embora seja uma das exigências educacionais da modernidade. Essa é uma forma ampla de educação, que se propõe a atingir a todos, através de um processo pedagógico participativo permanente.

A EA não é algo que está simplesmente na moda. Ela possui funções e papéis duradouros e bem definidos, relacionados com o presente e o futuro de nosso planeta, sem se esquecer de mencionar os fatos passados que nos servem de lição.

Na conferência de Tbilisi, foi criado o conceito da educação ambiental:

É um processo contínuo no qual os indivíduos e a comunidade tomam consciência de seu ambiente e adquirem o conhecimento, os valores, as habilidades, as experiências e a determinação que os tornem aptos a agirindividual e coletivamente - e resolver os problemas ambientais presentes e futuros. (UNESCO, 1977).

A concepção de meio ambiente na conferência de Tblilisi assumiu uma maior amplitude, passando a conceber, além dos fatores físicos e biológicos, também outros fatores como o social, político, técnico, ético, cultural e econômico, fornecendo assim à educação ambiental novos horizontes de trabalho que levaram à elaboração de propostas mais globais e eficazes, contidas nos princípios da educação ambiental, advinda desta conferência:

1) Considerar o ambiente em sua totalidade - natural, artificial, tecnológico e social (econômico, politico, histórico-cultural, ético e estético);

2) Ser um processo contínuo ao longo da vida, iniciando-se na pré- escola e prosseguindo por todos os estágios seguintes, formais e não formais;

3) Ser interdisciplinar em suas abordagens, utilizando o conteúdo específico de cada disciplina para tornar possível uma perspectiva equilibrada e holística;

4) Examinar as questões ambientais maiores a partir do ponto de vista locais, nacionais, regionais, e internacionais, para que os estudantes recebam informações sobre as condições ambientais em outras áreas geográficas;

5) Focar em questões ambientais potenciais e atuais sem descurar a perspectiva histórica;

6) Promover o valor e a necessidade da cooperação, local, nacional e internacional, na prevenção e soluções de problemas ambientais;

7) Explicitamente considerar os aspectos ambientais em planos para o desenvolvimento e crescimento;

8) Capacitar estudantes a terem um papel no planejamento de suas experiências de aprendizagem e providenciar-lhes oportunidade de tomar decisões e aceitar suas consequências;

9) Relacionar, para todas as idades, sensibilidade ambiental, conhecimento, habilidade de solução de problemas e valores, mas com especial ênfase em sensibilidade ambiental para os aprendizes da comunidade em tenra idade;

10) Ajudar aprendizes a descobrirem sintomas e causas reais de problemas 
ambientais;

11) Enfatizar a complexidade dos problemas ambientais, e a necessidade de desenvolver consciência crítica e habilidade de solução de problemas;

12) Utilizar diversos ambientes de aprendizagem e uma ampla coleção de métodos educacionais, para que possa ensinar e aprender sobre o ambiente, com devida atenção em atividade práticas e experiências originas. (UNESCO, 1977).

\section{LEIS QUE REGEM A EDUCAÇÃO AMBIENTAL NO BRASIL E EM PERNAMBUCO}

As leis que tratam sobre o meio ambiente no Brasil estão entre as mais completas e avançadas do mundo. Até meados da década de 1990, a legislação cuidava separadamente dos bens ambientais de forma não relacionada. É bem verdade que o trabalho de fiscalização ambiental tem falhas, pelo baixo número de profissionais e pessoas qualificadas para exercerem a função. A legislação é vasta com as garantias dos direitos e deveres, faltando inclusive o seu conhecimento pela população.

A primeira vez que a educação ambiental aparece na legislação de modo integrado é na Lei Federal 6.938, de 1981, que institui a Política Nacional de Meio Ambiente (art. 2, x). Essa lei, posteriormente, é recepcionada pela Constituição Federal de 1988, no capítulo VI, dedicado ao meio ambiente.

De acordo com a Constituição Federal, Art. 225, caput, todos temos direito ao meio ambiente ecologicamente equilibrado. É um bem de uso comum e essencial à boa qualidade de vida. Assim, o poder público e a coletividade têm o dever de defendê-lo e preservá-lo para esta e futuras gerações. Para assegurar a efetividade desse direito, incumbe ao poder público, entre outras providências, promover a educação ambiental em todos os níveis de ensino e a conscientização pública para a preservação do meio ambiente (§ $1^{\circ}$, VI). A educação ambiental tornou- se, então, um dever do estado.

Na constituição do Estado de Pernambuco (1989), no titulo VII, capitulo IV, seção I, artigo 209, é instituído a educação ambiental em todos os níveis de ensino formal, de maneira integrada e multidisciplinar, e como uma necessidade premente.

A nova Lei de Diretrizes e Base (LDB), instituída pela Lei federal No 9394 de 20/12/96, não estabeleceu nenhuma disposição sobre educação ambiental e sequer a cita expressamente. Apenas com muita boa vontade é que se pode atribuir ao legislador alguma intenção de tratar esse tema, ainda que de modo indireto.

\section{A BASE NACIONAL COMUM CURRICULAR (BNCC)}

A Base Nacional Comum Curricular (BNCC) é um documento que estabelece as propostas pedagógicas para a educação, na qual é referência obrigatória para a elaboração dos 
currículos escolares, para as redes de ensino e suas instituições públicas e privadas, fazendo parte do plano educacional nacional desde 1998 prevista na Constituição Federal.

A primeira versão deste documento foi criada em 2014, mas só foi aberta para o público em 2015, em que 45 mil escolas puderam contribuir com suas opiniões. Em 2016 foi criada a segunda versão na qual todo o país pôde opinar. Em 2017 foi realizada a terceira e última versão deste documento, que foi homologado em 22 de dezembro de 2017. A Base Nacional Comum Curricular é dividida em três partes que correspondem às etapas da educação básica: educação infantil, ensino fundamental e ensino médio.

A Base Nacional Comum Curricular (BNCC) divide a educação infantil em três blocos: bebês (zero a 1 ano e 6 meses), crianças bem pequenas ( 1 ano e 7 meses a 3 anos e 11 meses) e crianças pequenas ( 4 anos a 5 anos e 11 meses). Também são estabelecidos na BNCC os seis eixos estruturantes da Educação Infantil: conviver, brincar, participar, explorar, expressar e conhecer. A partir desses eixos são estabelecidos os cincos campos de experiências: Eu, o outro e o nós; Corpo, gestos e movimentos; Traços, sons, cores e formas; Escuta, fala, pensamento e imaginação; Espaço, tempo, quantidades, relações e transformações.

A educação ambiental é um tema que deve ser trabalhado de forma interdisciplinar, para garantir que aconteça a construção de uma consciência sustentável, embora a Base Nacional Comum Curricular (BNCC) não determine o uso da educação ambiental de maneira interdisciplinar. Apenas no campo de experiências "Espaços, tempos, quantidades, relações e transformações", é que a educação ambiental ganha um pequeno espaço para ser trabalhada dentro da sala de aula, pois a base estabelece que: "Educação Infantil precisa promover experiências nas quais as crianças possam fazer observações, manipular objetos, investigar e explorar seu entorno." (BNCC, 2017, p. 42).

\section{O REFERENCIAL CURRICULAR NACIONAL: EIXO NATUREZA E SOCIEDADE}

O Referencial Curricular Nacional para educação infantil foi um documento desenvolvido para nortear os profissionais da educação que atuavam com crianças de zero a seis anos que representou um grande avanço para a época, mas em 2019 entrou em desuso, sendo substituído pela Base Nacional Comum Curricular (BNCC), a qual foi homologada em 20 de dezembro de 2017.

Esse documento abrangia os objetivos, conteúdos e orientações pedagógicas que respeitavam as diferentes culturas do país. Os referencias eram divididos em três volumes. O primeiro volume trazia a introdução do documento onde havia reflexões e conceitos sobre a pré-escola e creches, além de manifestar os fundamentos sobre educação, instituição, criança 
e profissional. O segundo volume tratava da formação pessoal e social e dos processos e etapas do desenvolvimento da identidade e da autonomia de cada indivíduo. O terceiro volume denominado "conhecimento de mundo" era o documento que tratava dos seis eixos de trabalho e orientação para estabelecerem os objetivos dos conhecimentos das crianças. (BRASIL, 1998).

Entre os eixos estabelecidos no referencial curricular nacional, o de natureza e sociedade corresponde ao foco desta pesquisa. Neste eixo foram elaboradas as práticas docentes referentes à educação ambiental. Esse documento estabelecia que as crianças tomassem consciência do mundo de diferentes maneiras e etapas. Por esta razão foram criadas orientações didáticas para inserir a temática em sala de aula, por meio de atividades lúdicas e de maneira interdisciplinar.

Além de orientar os professores sobre a temática e a forma de atuação para inserir a educação ambiental na sala de aula, o documento também questionava a forma de muitas escolas só debaterem o tema em datas comemorativas superficialmente, não atribuindo o que de fato é o meio ambiente.

O volume três ainda organizava os conteúdos em blocos, visando comtemplar todas as dimensões contidas neste eixo, que são: "Organização dos grupos e seu modo de ser, viver e trabalhar"; "Os lugares e suas paisagens"; "Objetos e processos de transformação"; "Os seres vivos"; e "Fenômenos da natureza". Esta organização tinha o objetivo de facilitar a compreensão e o aprendizado dos alunos, assim como na dinâmica dos professores.

\section{METODOLOGIA}

No presente trabalho foi realizada uma análise de como professores da Educação Infantil relacionam a Educação Ambiental e a Educação Infantil. Esta pesquisa foi realizada com seis professores atuantes em instituições públicas, no período de setembro de 2020. Estes professores foram escolhidos, pois todos atuam na educação infantil, sendo que dois deles também atuam em cursos de educação ambiental e um deles atua também em curso de agroecologia.

Esta pesquisa é de caráter qualitativo, uma vez que pretende discutir as questões acerca da educação ambiental, não visando quantificar dados, mas refletir acerca dos dados encontrados dentro de um determinado contexto.

Pautando os estudos na interpretação do mundo real o pesquisador, ao realizar uma pesquisa qualitativa, preocupa-se com o caráter hermenêutico de pesquisar sobre a experiência de vida dos seres humanos, ou seja, a técnica de interpretar e explicar um texto. 
(MOREIRA, 2002, p. 50-51).

As informações constantes neste trabalho foram obtidas por meio de um questionário com perguntas abertas e fechadas sobre o tema abordado e foram respondidas por professores que atuam na educação infantil e trabalham em escolas públicas situadas nos municípios de Jaboatão dos Guararapes, Cabo de Santo Agostinho e Glória do Goitá.

Os sujeitos participantes desta pesquisa, professores da Educação Infantil e atuantes em cursos de educação ambiental e agroecologia, tiveram total liberdade para responder todas as questões, sem direcionamento do pesquisador. Foi apresentado um termo de consentimento para os participantes que quiseram participar, mantendo-os protegidos de qualquer exposição.

\section{RESULTADOS}

Para o presente estudo participaram seis professores, sendo três atuantes na Educação Infantil e três atuantes em cursos especializados em educação ambiental como também na educação infantil. Todos os entrevistados têm formação superior na área da Educação e três deles possuem especialização na área de educação ambiental. Todos os docentes participantes atuam em instituições públicas.

\section{Quadro 01 - Dados gerais dos professores participantes}

\begin{tabular}{|l|l|l|l|l|}
\hline Professores & $\begin{array}{l}\text { Nível de } \\
\text { formação }\end{array}$ & $\begin{array}{c}\text { Tempo que } \\
\text { leciona }\end{array}$ & $\begin{array}{l}\text { Nível de ensino } \\
\text { que trabalha }\end{array}$ & $\begin{array}{c}\text { Localidade de } \\
\text { atuação } \\
\text { (município) }\end{array}$ \\
\hline Professor 01 & Especialização & $\begin{array}{l}\text { Acima de 6 } \\
\text { anos }\end{array}$ & Educação Infantil & $\begin{array}{l}\text { Jaboatão dos } \\
\text { Guararapes }\end{array}$ \\
\hline Professor 02 & Especialização & $\begin{array}{l}\text { Acima de } \\
12 \text { anos }\end{array}$ & $\begin{array}{l}\text { Educação } \\
\text { Infantil }\end{array}$ & $\begin{array}{l}\text { Jaboatão dos } \\
\text { Guararapes }\end{array}$ \\
\hline Professor 03 & Especialização & $\begin{array}{l}\text { Acima de 15 } \\
\text { anos }\end{array}$ & $\begin{array}{l}\text { Educação Infantil } \\
\text { Acima de 15 } \\
\text { anos }\end{array}$ & $\begin{array}{l}\text { Cursoatão dos } \\
\text { Guararapes }\end{array}$ \\
\hline Professor 04 & Especializaçãagia & $\begin{array}{l}\text { Educação } \\
\text { Infantil } \\
\text { Agostinho de Santo }\end{array}$ \\
\hline Professor 05 & Especialização & Acima 20 anos & $\begin{array}{l}\text { Curso pedagogia } \\
\text { ambiental; } \\
\text { Educação } \\
\text { Infantil }\end{array}$ & $\begin{array}{l}\text { Cabo de Santo } \\
\text { Agostinho }\end{array}$ \\
\hline
\end{tabular}




\begin{tabular}{|l|l|l|l|l|}
\hline Professor 06 & Especialização & $\begin{array}{l}\text { Acima de 15 } \\
\text { anos }\end{array}$ & $\begin{array}{l}\text { Curso } \\
\text { agroecologia; } \\
\text { Educação } \\
\text { Infantil }\end{array}$ & Glória do Goitá \\
\hline
\end{tabular}

Fonte: as autoras

Todos os professores entrevistados, como visto no quadro 01, apresentam mais de 06 anos de experiência, o que traz a discussão sobre seus saberes experienciais. Os saberes experienciais são aqueles que se desenvolvem no cotidiano da atividade docente e, por isso, levam em conta as múltiplas interações existentes na prática. Com a experiência de ensino, o professor começa a elaborar sua forma de lidar com as mais diversas situações que ocorrem na sala de aula, e na sua profissão como um todo. Esses saberes, de acordo com Tardif (2002), também são compostos da experiência compartilhada com outros docentes, já que o professor não é um profissional que atua sozinho e isolado. Entendemos, então, que os professores participantes da presente pesquisa já apresentam seus saberes e sua prática consolidada, trazendo reflexões mais elaboradas e concisas sobre as questões educacionais em que eles se envolvem.

Nesse contexto, acreditamos que o professor já está preparado para lidar com situações inesperadas e tem autonomia para tomar as decisões que precisam ser tomadas em sua sala de aula.

Observando o quadro acima, percebemos que três dos entrevistados não atuam diretamente com a educação ambiental e sim com a educação infantil. Já os outros entrevistados trabalham diretamente com a educação ambiental e também atuam com a educação infantil. Consequentemente, os professores que atuam de forma direta nas duas áreas têm mais facilidade de inserir a educação ambiental no cotidiano de suas turmas.

No questionário utilizado para a pesquisa foi perguntado sobre os incentivos do governo para a prática da educação ambiental na escola. Dos seis professores um não respondeu e os outros cinco responderam que não há incentivo por parte do governo para que a educação ambiental aconteça de forma contínua no ambiente escolar. Eles citaram alguns exemplos de incentivos necessários para o bom funcionamento da educação ambiental na escola: formação para os próprios professores na área da educação ambiental, ambientes apropriados para aulas externas onde o aluno possa ter contato com o meio ambiente dentro ou fora da escola, e materiais didáticos voltados para a educação ambiental.

Logo em seguida os professores refletiram acerca da escolha pela área da educação infantil e qual a sua importância. Dos seis docentes, dois afirmaram que não escolheriam a 
área da educação novamente, pois é muito desgastante, mas que a educação é de extrema importância para o desenvolvimento da sociedade. Quatro pesquisados afirmaram que escolheriam a área da educação novamente por inúmeros motivos, como por exemplo, por gostar de lecionar, ver os alunos progredindo e avançando na aprendizagem, por não se ver fazendo outra atividade, por amar o que faz e por afirmar que a pedagogia é uma das profissões mais bonitas que existe. É através da educação escolar que as crianças, além de aprenderem a ler e escrever, aprendem também a se relacionar com o outro, desenvolvendo suas habilidades e tomando consciência do convívio em sociedade.

Ao serem questionados sobre como promover a educação ambiental em sala de aula na educação infantil, os professores listaram algumas sugestões, como podemos ver no quadro 02. Vale ressaltar que os professores puderam destacar mais de uma alternativa.

Quadro 02 - Ações atreladas à promoção da educação ambiental

\begin{tabular}{|l|l|}
\hline \multicolumn{1}{|c|}{ Melhorias } & $\begin{array}{l}\text { Quant. } \\
\text { Professores }\end{array}$ \\
\hline Separação do lixo que produzem dentro da sala de aula & 05 \\
\hline Construir uma horta coletiva & 06 \\
\hline Visitas às reservas naturais & 04 \\
\hline $\begin{array}{l}\text { Utilizar copos, pratos e talheres reutilizáveis, na hora da merenda } \\
\text { escolar }\end{array}$ & 06 \\
\hline Economizar água & 05 \\
\hline Outros & 02 \\
\hline
\end{tabular}

Fonte: as autoras

Os professores que marcaram a opção "outros" citaram o plantio de árvores, aulas ao ar livre, além de incentivos financeiros para a criação de espaços verdes nas escolas. Neste contexto, notamos que, apesar dos professores relatarem que não há incentivo por parte do governo, muito ainda pode ser feito para o envolvimento dos alunos com a educação ambiental sem tirar o foco das outras disciplinas.

De acordo com o Índice de Desenvolvimento Ambiental 2020, o Environmental Performance Index (EPI), o Brasil é o $55^{\circ}$ no ranking da sustentabilidade, porém, os incêndios que ocorreram na Amazônia, Pantanal e a atual pandemia do covid-19 não entraram no índice de 2020. Dessa forma, refletimos sobre a necessidade de uma pedagogia ambiental, mas presente no dia a dia escolar.

Nessa discussão, percebemos que os professores entrevistados têm um olhar bem semelhante quando a questão é a execução da educação ambiental dentro da sala de aula. A educação ambiental é um processo de aprendizagem sobre os recursos naturais e sua 
preservação e, de acordo com Guimarães (2001), esse parecer aponta para uma transformação nas relações do ser humano com a natureza e com a sociedade, que envolve a construção de uma nova ética, novas culturas e novos conhecimentos reflexivos.

Foi perguntado aos docentes quais efeitos podem acarretar em um indivíduo que desde seus primeiros anos escolares teve acesso à educação ambiental. Todos deram respostas positivas, afirmando que se uma pessoa nos seus primeiros anos na escola tiver acesso a uma educação ambiental de qualidade, se tornará um cidadão consciente de suas ações, capaz de resolver problemas ambientais em sua comunidade e suas ações se tornam sustentáveis.

"Os efeitos são positivos, pois as crianças se tornarão adultos conscientes de suas ações.” (Depoimento do professor 02).

"Os alunos serão mais conscientes em relação aos cuidados com o meio ambiente, terão mais cuidado na hora de descartar o lixo e cuidarão melhor da comunidade onde vivem." (Depoimento do professor 04).

"As crianças que tiverem acesso a uma boa educação ambiental durante todo o seu percurso de aprendizagem escola, com toda a certeza serão bem mais hábeis em resolver problemas ambientais e encontrar maneiras sustentáveis de viver em sociedade." (Depoimento do professor 05).

Podemos perceber, a partir dos trechos da fala dos docentes, que uma educação ambiental presente e ativa no cotidiano escolar acarreta mudanças no comportamento dos alunos em longo prazo. Sato (1992) afirma que a "educação ambiental promove a aquisição de habilidades e competências para agir e resolver os problemas ambientais". Portanto, podemos considerar que a educação ambiental é uma garantia de um futuro onde o homem e a natureza viverão em equilíbrio.

Os professores foram questionados se a educação ambiental pode ser trabalhada de forma interdisciplinar. Dos seis entrevistados, dois responderam que não, que a educação ambiental deve ser uma disciplina obrigatória no currículo escolar, pois facilitaria tanto o planejamento como também o acesso a materiais didáticos voltados à educação ambiental. Os outros quatro docentes responderem sim, que a educação ambiental deve ser trabalhada em conjunto com outras disciplinas, visto que dessa forma a temática estaria presente diariamente em sala de aula.

"Não, a educação ambiental deve ser uma disciplina obrigatória, como português e matemática. Desse modo podemos garantir que a temática seja abordada em sala de aula e que ocorra a aprendizagem." (Depoimento do professor 01).

"Sim, a educação ambiental precisar ser abordada de forma interdisciplinar, para garantir que esteja presente no dia-a-dia da turma." (Depoimento do professor 03).

"Com certeza sim, a interdisciplinaridade é essencial para uma educação ambiental de qualidade, uma vez que podemos estabelecer uma relação 
harmônica com a educação ambiental com qualquer outra disciplina." (Depoimento do professor 06).

Diante das respostas dos entrevistados, podemos perceber que mesmo sem uma total concordância na forma de como a educação ambiental pode ser abordada, os docentes afirmam que ela pode ser trabalhada em sala de aula para garantir o desenvolvimento das habilidades e aprendizado. A lei n ${ }^{0}$ 9.795, de 27 de abril de 1999, art. 8, define que a educação ambiental seja inserida nos diferentes níveis e modalidades de ensino de forma interdisciplinar para que ocorra a junção da dimensão ambiental com as demais disciplinas, usando os mesmos instrumentos e metodologia.

Para encerrar o questionário foi perguntado qual a importância da educação ambiental nas creches e pré-escolas. Dos seis, dois afirmaram que é fundamental para o desenvolvimento de uma consciência sustentável para a preservação dos recursos naturais. Um afirmou que é essencial que desde cedo as crianças entendam que o meio ambiente deve ser cuidado e que os seres humanos fazem parte da natureza. Três afirmaram que a educação ambiental desde a creche e pré-escola é de extrema importância para formar cidadãos críticos que tomem consciência dos pequemos e grandes problemas ambientais que enfrentamos e que possam criar soluções para esses problemas. Pequenos hábitos sustentáveis devem estar presentes em seu dia-a-dia, como o simples trabalho de separar e descartar o lixo de forma correta.

\begin{abstract}
"É importante ter uma educação ambiental eficaz desde os anos iniciais e pelos anos subsequentes, não apenas voltada para o aluno, mas também para o educador e todos que fazem parte do sistema educacional, pois qualquer ação realizada pelo homem ao meio ambiente provoca impactos ambientais que pode ser positivo ou negativo. Infelizmente, os impactos em sua maioria são negativos. Com a existência de uma base ambiental, pode acarretar o desaparecimento de vários problemas ambientais, tal como alagamentos, extinção de espécies, mudanças climáticas, poluição e até queimadas, como a que houve no Pantanal que de acordo com as perícias realizadas, uma grande parte dos focos de incêndios foram causados pelas mãos humanas." (Depoimento do professor 05).
\end{abstract}

É possível observar neste depoimento do professor 05 que há pontos positivos em se ter uma educação ambiental ativa na educação infantil, para que ao longo do seu desenvolvimento escolar seja concretizada a consciência ambiental, não só do estudante, mas também dos demais agentes da educação.

\title{
CONSIDERAÇÕES FINAIS
}

Refletir sobre as questões ambientais é muito importante e nos faz perceber que para um bom desempenho da educação ambiental o professor precisar estar sempre buscando 
inovar, já que não existe exigência para a sua abordagem no cotidiano escolar.

Este trabalho apresenta alguns registros de pesquisas já realizadas, como também as respostas do questionário pelos professores, atuantes nas redes de Jaboatão dos Guararapes, Cabo de Santo Agostinho e Glória do Goitá.

De acordo com os docentes que participaram da presente pesquisa, há grandes problemas a serem resolvidos. Alguns desses problemas foram citados na pesquisa, como a falta de formação na área ambiental, espaços impróprios, materiais didáticos escassos ou inexistentes voltados para a educação ambiental. Com isso, podemos observar que a educação ambiental vive uma situação problemática dentro da escola, pois com tantas outras obrigatoriedades, os docentes vão deixando de lado, muitas vezes por falta de informações ou por falta de métodos de adaptar a temática em outras disciplinas, fazendo com que a educação ambiental não seja de fato integrada às outras disciplinas, e sim, que surge como um tema que se dissipa nas atividades desenvolvidas em sala.

O professor é peça fundamental no processo de ensino e aprendizagem e cabe ao Estado fornecer materiais didáticos voltados à educação ambiental para dar apoio ao docente para que ele desenvolva bem suas atividades. Quando falamos em garantias, trazemos as questões observadas nas leis abordadas neste trabalho, que garantem uma educação ambiental presente e de qualidade desde a creche e a pré-escola. Cabe aos governantes realizar os investimentos devidos para a formação de professores ainda mais qualificados para realizar atividades voltadas à sustentabilidade e ao meio ambiente.

Podemos observar que todos os professores que participaram da pesquisa, por estarem no exercício de sua profissão há mais de seis anos, têm certa propriedade para falar sobre o assunto. Entendemos, então, que a educação ambiental é de extrema importância na educação infantil para que se construa uma consciência ambiental forte, garantindo mudanças de comportamento e atitudes que garantam um futuro onde haja equilíbrio entre homem e a natureza.

\section{REFERÊNCIAS}

BRASIL. Lei $\mathbf{n}^{0}$ 9.975, de 27 de abril de 1999. Dispõe sobre a educação ambiental; institui a política nacional de educação ambiental e dá outras providências. Brasília, 1999.

BRASIL. Ministério da Educação e do Desporto. Secretaria de Educação Fundamental. Referencial Curricular Nacional para a Educação Infantil / Ministério da Educação e do Desporto, Secretaria de Educação Fundamental. — Brasília: MEC/SEF, 1998.

BRASIL. Ministério da Educação. Base Nacional Comum Curricular. Brasília, 2017. 
BRASIL. Lei $n^{\circ} 9.394$ de 20 de Dezembro de 1996. Ministério da Educação. Lei de Diretrizes e Bases da Educação Nacional (LDB). Disponível em: http://www.cartadaterrabrasil.com.br/prt/texto-da-carta-da- terra.html $>$. Acesso em: 21 nov. de 2020 .

DIAS, Genebaldo F. Educação ambiental princípios e práticas. São Paulo: Editora Gaia, 2004.

GADOTTI, Moacir. Pedagogia da terra. São Paulo: Ed. Peirópolis, 2000.

GUIMARÃES, Moura. A dimensão ambiental na educação. São Paulo: Editora Papirus, 2001.

PENTEADO, Heloísa D. Meio ambiente e formação de professores. São Paulo: Editora Cortez, 2010.

SATO, Michéle. Educação ambiental. São Carlos-SP: Editora Rima, 2004.

TARDIF, M., Saberes Docentes e Formação Profissional. Petrópolis: Editora Vozes, 2002.

UNESCO. Conferência Intergovernamental sobre Educação Ambiental. Tbilisi, 1977.

\section{APÊNDICE - QUESTIONÁRIO APLICADO}

Dados do entrevistado

Idade:

Há quanto tempo está lecionando?

Formação/graduação:

Qual área de atuação:

Questionário

1. Quais os incentivos do governo para a prática da educação ambiental na escola?

2. Se estivesse no inicio de sua carreira, você escolheria a área da educação infantil novamente? Se sim. Qual a importância que ela tem?

3. Como promover a educação ambiental em sala de aula na educação infantil?

4. Quais os efeitos podem acarretar em um indivíduo, que desde seus primeiros anos escolares teve acesso à educação ambiental? 
5. A educação ambiental pode ser trabalhada de forma interdisciplinar?

6. Qual a importância da educação ambiental nas creches e pré-escolas? 


\title{
EFEITOS DO TREINAMENTO RESISTIDO NA FORÇA MUSCULAR EM IDOSOS COM SARCOPENIA: ESTUDO DE REVISÃO LITERÁRIA
}

\author{
https://dx.doi.org/10.48097/2674-8673.2021n5p08
}

\author{
Jorge Cavalcanti Machado de Souza ${ }^{1}$ \\ Manuella Moraes Monteiro Barbosa Barros ${ }^{2}$
}

\section{RESUMO}

Com o aumento da longevidade o número de idosos vem crescendo exponencialmente, colaborando para o aparecimento de doenças como a sarcopenia, uma doença que gera perda de massa muscular, força e função. O maior problema do envelhecimento não é o processo em si, mas a falta de atividade que o acompanha, podendo comprometer a capacidade de realizar atividades diárias. Um fator fundamental para um envelhecimento saudável é a prática de atividade física regular. Este estudo teve como objetivo relatar os efeitos dos exercícios resistidos na força muscular nos idosos com sarcopenia. Foi possível concluir que o tratamento fisioterapêutico na sarcopenia é fundamental e extremamente necessário, atuando na prevenção, promoção e na reabilitação, melhorando a qualidade de vida, que é um fator determinante para uma longevidade no idoso.

Palavras-chave: Idosos. Exercícios resistidos. Sarcopenia.

Data de submissão: $23 / 03 / 2021$

Data de aprovação: 30/04/2021

\begin{abstract}
With the increase in longevity the number of elderly people has been growing exponentially, contributing to the appearance of diseases such as sarcopenia, a disease that generates loss of muscle mass, strength and function. The biggest problem with aging is not the process itself, but the lack of activity that accompanies it, which can compromise the ability to perform daily activities. A fundamental factor for healthy aging is the practice of regular physical activity. This study aimed to report the effects of resistance exercises on muscle strength in the elderly with sarcopenia. It was possible to conclude that physiotherapeutic treatment in sarcopenia is fundamental and extremely necessary, acting on prevention, promotion and rehabilitation, improving quality of life, which is a determining factor for longevity in the elderly.
\end{abstract}

Keywords: Elderlies. Resistance exercises. Sarcopenia.

\section{INTRODUÇÃO}

A população mundial apresenta um número crescente de idosos. É certo que isto é consequência do processo evolutivo e tecnológico para a melhoria da qualidade de vida da

\footnotetext{
${ }^{1}$ Discente do curso de Fisioterapia da Faculdade Metropolitana da Grande Recife.

E-mail: jorgecmachado57@gmail.com

2 Docente orientadora do curso de Fisioterapia da Faculdade Metropolitana da Grande Recife.

E-mail: manuella@metropolitana.edu.br
} 
população. Ocorreu um maior incentivo científico nos processos de compreensão das enfermidades crônicas degenerativas, maior preocupação na percepção saúde-doença, programas governamentais de incentivo ao aumento do acesso aos serviços de saúde e elevação da expectativa de vida. Quando existe a prática regular do exercício resistido ocorre uma melhora no controle das entidades patológicas. Observa-se desde 1940, no Brasil, um incremento do número de idosos sobre os adultos jovens. Na década seguinte, as taxas foram na ordem de $3 \%$ e nos últimos dez anos de 2000 , houve elevação na ordem de $3,4 \%$. Um novo fenômeno foi desenhado com uma população de idosos crescendo na ordem de 126,3\% enquanto dos adultos foi de 55,3\% entre 1980 e 2005. (CARDOSO et al., 2012; GORDON et al, 2012; INOUYE, PEDRAZZANI, PAVARINI, 2008).

Com as mudanças na dinâmica demográfica da população idosa no Brasil e no mundo este nicho de pessoas tem se mostrado crescente. Nas últimas seis décadas houve um acréscimo de 15 milhões de indivíduos idosos no país, passando de 4\% para $9 \%$ da população brasileira. Provavelmente em 2025 teremos um aumento de mais 33 milhões, tornando o Brasil o sexto país com maior índice percentual populacional de idosos no mundo. Assim como a elevação do número de idosos também há um crescimento de algumas doenças e comorbidades relacionadas ao processo natural de envelhecimento, dentre estes, pode-se destacar a sarcopenia. (PÍCOLI et al 2011; PARAHYBA, 2006; FREITAS, 2006; SILVA et al, 2006).

Novas demandas de saúde estão ocorrendo devido às mudanças sócio-demográficas da população mundial, adicionando-se novas demandas de saúde. O envelhecimento é um dos fatores que apontam mudanças epidemiológicas no perfil das doenças, induzindo a maior incidência de doenças crônicas degenerativas e suas complicações. Pode-se apresentar a síndrome da fragilidade e a sarcopenia, tendo em vista os malefícios que exercem na funcionalidade e na qualidade de vida dos idosos. (VIANA et al., 2013).

Guedes et al (2008), relatam que com a idade avançada algumas modificações fisiológicas ocorrem, como a diminuição da força muscular, diminuição da frequência cardíaca máxima, diminuição da massa muscular, diminuição da coordenação motora, diminuição da flexibilidade, diminuição da propriocepção, diminuição do metabolismo basal e aumento da gordura corporal.

Segundo Mazo et al (2007), o declínio do sistema locomotor, causado pelo processo da senescência e/ou senilidade, são causas de incapacidade e falta de equilíbrio que aumentam os riscos de quedas, podendo levar muitas vezes à incapacidade de manter-se equilibrado, prejudicando funções básicas do cotidiano. O período da velhice é muito associado ao 
declínio das funções corporais e mentais, o que desestimula o idoso a procurar uma prática que reduza os impactos do envelhecimento. Assim, tornam-se menos ativos à medida que aumentam de idade, contribuindo para a redução de sua independência social. (GIELEN et al., 2015).

Conforme Garcia (2011), estima-se uma redução de 20 a 40 por cento na força muscular e na mobilidade funcional em idosos de 70 a 80 anos. Essa perda de massa e força muscular definida como sarcopenia é inevitável com o envelhecimento e é uma das alterações fisiológicas mais importantes que ocorrem em adultos mais velhos. A redução da força muscular e da potência muscular e a consequente redução da mobilidade funcional em idosos se devem ao declínio da massa muscular associado ao envelhecimento.

O sedentarismo, a ociosidade e a facilidade na comunicação são os maiores incentivadores do estilo de vida não saudável. A prevenção desse estilo de vida deve ser observada a fundo, pois viver desta forma nos impede de realizar práticas corporais, as quais são fundamentais para nossa qualidade de vida e para um envelhecimento saudável (MINISTÉRIO DA SAÚDE, 2006). Atualmente, a procura por exercícios resistidos em idosos é consequência de indicação médica ou pela busca de uma qualidade de vida mais abundante. Ao compreender a importância de ter uma vida ativa, as pessoas tornam-se adeptas a essa prática.

De acordo com Nicastro \& Peterson (2011) e Waters (2010), devido à magnitude dos desfechos adversos da independência do idoso, qualidade de vida e aumento da carga sobre os sistemas de saúde, diversas estratégias possíveis para prevenir e /ou tratar a sarcopenia foram desenvolvidas ao longo dos anos. Apesar dos recursos nutricionais, hormonais e farmacológicos, o treinamento resistido é citado como um dos melhores caminhos para o tratamento da sarcopenia. As adaptações morfológicas e funcionais ao exercício resistido foram bem descritas na literatura e o treinamento resistido progressivo deve melhorar as alterações neuromusculares, força muscular, massa muscular e desempenho em idosos.

Segundo Cruz-Jentoft et al (2011), exercícios de resistência consistem em realizar contrações dinâmicas ou estáticas contra a resistência, como levantar pesos, usar máquinas de resistência ou faixas elásticas. Esses exercícios de resistência aumentarão o conteúdo de mioglobina muscular entre $75 \%$ e $80 \%$, o que favorece o armazenamento de oxigênio, aumenta o número e o tamanho das mitocôndrias e aumenta as enzimas oxidativas. Todas essas mudanças que ocorrem nos músculos, juntamente com as adaptações no sistema de transporte de oxigênio, produzem um funcionamento mais intenso do sistema oxidativo e uma melhora na capacidade de resistência. Além disso, esse tipo de exercício não apenas aumenta 
a massa e a força muscular, mas também melhora outros aspectos como equilíbrio, capacidade aeróbica, flexibilidade e outras limitações funcionais. Esse treinamento é importante em idosos, mas, para tirar proveito dele, é necessário levar em consideração a relação entre intensidade e duração.

De acordo com o Colégio Americano de Medicina Esportiva (2009), esses exercícios devem ser realizados de 2 a 3 dias por semana, em 1 a 3 séries de 8 a 12 repetições cada, incluindo os 8 a 10 principais grupos musculares, com uma intensidade de $70 \%$ a $80 \%$ da potência máxima que pode ser realizada com esse grupo muscular e com um minuto de descanso entre as séries.

Nos estudos avaliados por Miyazaki et al. (2016), o exercício resistido melhora significativamente a força muscular e a hipertrofia, sendo atribuído ao exercício resistido a capacidade de ganho de força.

Diante do exposto, o objetivo deste estudo foi pesquisar, através de uma revisão literária, o efeito da sarcopenia, ocasionado pelo sedentarismo que ele implica na funcionalidade dos membros superiores e inferiores, na massa corporal e força muscular dos idosos.

\section{METODOLOGIA}

Trata-se de uma revisão descritiva de literatura cujo objetivo geral foi verificar o impacto da sarcopenia e o efeito dos exercícios resistidos na funcionalidade de idosos $(\geq 60$ anos). Foram pesquisados artigos escritos e disponíveis na plataforma do site da Biblioteca Virtual de Saúde nos idiomas português e inglês, que estivessem indexados nas bases de dados "Medical Literature Analysis and Retrieval System Online" (MEDLINE), Scientific Eletronic Library Online (SCIELO) e Literatura Latino-Americana e do Caribe em Ciências da Saúde (LILACS), usando como descritores: "Idoso", "Sarcopenia" e "Exercícios Resistido" (“Aged", "Sarcopenia", "Exercise").

No rastreamento das publicações foi utilizado o operador booleano "AND", de modo a combinar os termos descritores acima citados. Foram encontrados 92 artigos no MEDLINE, 13 artigos no SCIELO e não foi encontrado nenhum no LILACS, totalizando 105 estudos.

As buscas dos artigos foram realizadas no período de março a maio do ano de 2020, ressaltando que não ocorreu restrição temporal. Os idiomas pesquisados foram inglês e português e foi usado o filtro de Ensaio Clínico para busca dos artigos. Os critérios de inclusão concentram-se nos artigos científicos de sarcopenia em idosos ( $\geq 60$ anos), exercícios 
resistidos, definição terapêutica e fisioterápica. Foram considerados critérios de exclusão a sarcopenia decorrente de patologias autoimunes, doenças metabólicas, cardiológicas, pulmonares, neurológicas e cognitivas.

\section{RESULTADOS}

A seleção dos estudos foi realizada inicialmente com a leitura do título e resumo dos trabalhos, sendo selecionados os que abordassem o objetivo geral dessa revisão descritiva de literatura. Dos 105 estudos encontrados apenas 17 foram lidos na íntegra. Destes, 08 foram contemplados para explanação dos dados, sendo submetidos a uma análise qualitativa e integral com aprofundamento de seus conteúdos. As etapas da revisão dos estudos estão na Figura 1 e os dados dos estudos selecionados estão contidas na tabela 1.

Figura 1. Fluxograma das etapas do estudo baseado no modelo Prisma 2009
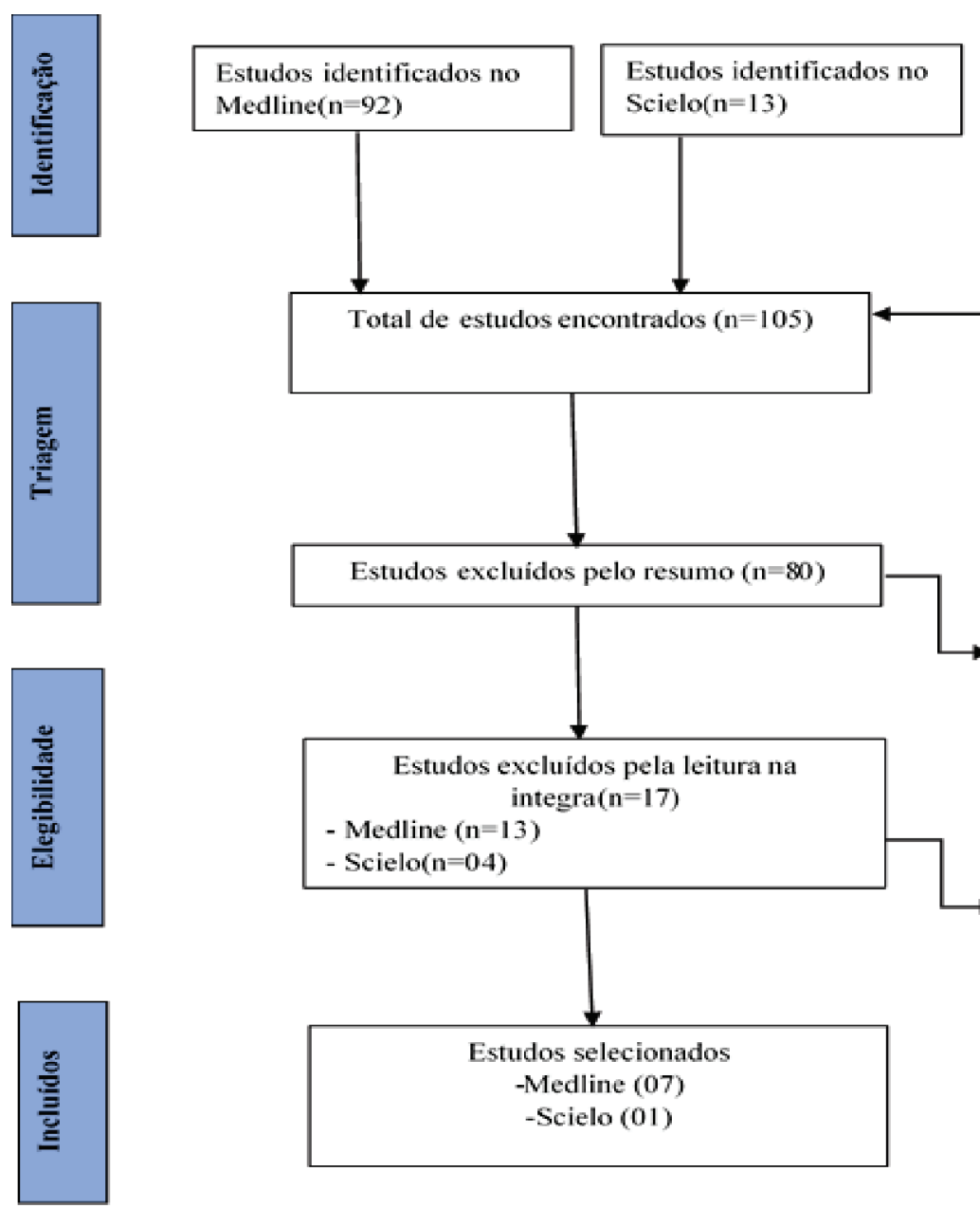

Estudos identificados no Lilacs $(\mathbf{n}=0)$

Estudos excluídos por motivo:

doenças correlacionadas

- Medline $(\mathrm{n}=13)$

- Scielo $(\mathrm{n}=06)$

Nầ está de acordo com o

objetivo:

- Medline (59)

-Scielo ( 02$)$

Estudos excluidos por motivo:

Fora do contexto

- Medline $(n=13)$

- Scielo $(n=4)$

Fonte: os autores 
Tabela 1. Características dos estudos elegíveis para revisão.

\begin{tabular}{|c|c|c|c|c|c|}
\hline Autores/ Ano & $\begin{array}{l}\text { Título do } \\
\text { Estudo }\end{array}$ & $\begin{array}{l}\text { Tipo do } \\
\text { Estudo }\end{array}$ & Objetivos & Resultado & Conclusão \\
\hline $\begin{array}{l}\text { PIASTRA et al. } \\
2018\end{array}$ & $\begin{array}{l}\text { Effects of } \\
\text { Two Types of } \\
\text { 9-Month } \\
\text { Adapted } \\
\text { Physical } \\
\text { Activity } \\
\text { Program on } \\
\text { Muscle Mass, } \\
\text { Muscle } \\
\text { Strength, and } \\
\text { Balance in } \\
\text { Moderate } \\
\text { Sarcopenic } \\
\text { Older Women }\end{array}$ & $\begin{array}{l}\text { Ensaio } \\
\text { clínico } \\
\text { randomiza } \\
\text { do. }\end{array}$ & $\begin{array}{l}\text { Avaliar os efeitos } \\
\text { de dois tipos de } \\
\text { programa ras de } \\
\text { atividade física } \\
\text { adaptada (APA) de } \\
9 \text { meses, baseados } \\
\text { em treinamento de } \\
\text { reforço muscular e } \\
\text { treinamento sobre } \\
\text { postural muscular, } \\
\text { massa muscular e } \\
\text { força mático } \\
\text { equilíbrio estáto } \\
\text { em idosos } \\
\text { sarcopênicos } \\
\text { moderados } \\
\text { mulheres. }\end{array}$ & $\begin{array}{l}\text { O estudo } \\
\text { realizado em } \\
\text { mulheres } \\
\text { idosas } \\
\text { sarcopênicas } \\
\text { moderadas, } \\
\text { demonstrou } \\
\text { que o grupo } \\
\text { RESISTANCE } \\
\text { apresentou } \\
\text { melhoras } \\
\text { significativas } \\
\text { na massa e } \\
\text { função } \\
\text { muscular após } \\
\text { o programa de } \\
\text { reforço } \\
\text { muscular } \\
\text { proposto, } \\
\text { enquanto que } \\
\text { não foram } \\
\text { encontradas } \\
\text { diferenças } \\
\text { significativas } \\
\text { no grupo } \\
\text { POSTURAL, } \\
\text { após o } \\
\text { treinamento } \\
\text { postural } \\
\text { adotado. }\end{array}$ & $\begin{array}{l}\text { Os presentes } \\
\text { achados mostram a } \\
\text { eficácia de um } \\
\text { programa de reforço } \\
\text { muscular na massa e } \\
\text { função muscular, } \\
\text { bem como nos } \\
\text { parâmetros de } \\
\text { equilíbrio estático } \\
\text { em mulheres idosas } \\
\text { sarcopênicas. Esse } \\
\text { tipo de abordagem } \\
\text { pode reduzir fatores } \\
\text { de risco de queda, } \\
\text { como sarcopenia e } \\
\text { comprometimento } \\
\text { do equilíbrio. }\end{array}$ \\
\hline $\begin{array}{l}\text { YAMADA et al. } \\
2019\end{array}$ & $\begin{array}{l}\text { Synergistic } \\
\text { effect of } \\
\text { bodyweight } \\
\text { resistance } \\
\text { exercise and } \\
\text { protein } \\
\text { supplementati } \\
\text { on on skeletal } \\
\text { muscle in } \\
\text { sarcopenic or } \\
\text { dynapenic } \\
\text { older adults. }\end{array}$ & $\begin{array}{l}\text { Estudo } \\
\text { controlado } \\
\text { randomiza } \\
\text { do de } \\
\text { quatro } \\
\text { braços. }\end{array}$ & $\begin{array}{l}\begin{array}{l}\text { Investigar os efeitos } \\
\text { do exercício } \\
\text { resistido ao peso } \\
\text { corporal }\end{array} \text { e } \\
\text { suplementação de } \\
\text { proteínas e vitamina } \\
\text { D no músculo } \\
\text { esquelético r em } \\
\text { idosos sarcopênicos } \\
\text { e dinapênicos. }\end{array}$ & $\begin{array}{l}\text { Os } \\
\text { participantes } \\
\text { do grupo } \\
\text { combinado } \\
\text { tiveram uma } \\
\text { melhora } \\
\text { significativame } \\
\text { nte maior na } \\
\text { intensidade do } \\
\text { eco do reto } \\
\text { femoral e no } \\
\text { torque de } \\
\text { extensão do } \\
\text { joelho do que } \\
\text { os dos outros } \\
\text { grupos. Além } \\
\text { disso, } \\
\text { programa } \\
\text { combinado } \\
\text { aumentou a } \\
\text { massa } \\
\text { muscular } \\
\text { apendicular em } \\
\text { idosos } \\
\text { sarcopênicos, }\end{array}$ & $\begin{array}{lr}\text { Um programa } \\
\text { combinado de } 12 \\
\text { semanas re } \\
\text { exercícios resistidos } \\
\text { ao peso corporal e } \\
\text { suplementação de } \\
\text { proteínas e vitamina } \\
\text { D é eficaz para } \\
\text { melhorar r a } \\
\text { qualidade muscular } \\
\text { e a força muscular } \\
\text { em idosos com } \\
\text { sarcopenia } \\
\text { dinapenia. }\end{array}$ \\
\hline
\end{tabular}


mas não em

idosos com

baixa função

física e massa

muscular

normal.

\begin{tabular}{|c|c|c|c|c|c|}
\hline $\begin{array}{l}\text { Hiroyasu } \\
\text { Mori e Yasunob } \\
\text { u Tokuda } \\
2018\end{array}$ & $\begin{array}{l}\text { Effect of } \\
\text { whey protein } \\
\text { supplementati } \\
\text { on after } \\
\text { resistance } \\
\text { exercise on } \\
\text { the muscle } \\
\text { mass and } \\
\text { physical } \\
\text { function of } \\
\text { healthy older } \\
\text { women: A } \\
\text { randomized } \\
\text { controlled } \\
\text { trial }\end{array}$ & $\begin{array}{l}\text { Estudo } \\
\text { controlado } \\
\text { randomiza } \\
\text { do. }\end{array}$ & $\begin{array}{l}\text { Avaliar a eficácia } \\
\text { de um programa de } \\
24 \text { semanas de } \\
\text { suplementação } \\
\text { nutricional com } \\
\text { proteína de soro de } \\
\text { leite, ingerida após } \\
\text { exercícios, no } \\
\text { aumento da massa } \\
\text { muscular e da } \\
\text { função física entre } \\
\text { mulheres japonesas } \\
\text { saudáveis. }\end{array}$ & $\begin{array}{l}\text { O aumento pré } \\
\text { e pós- } \\
\text { intervenção no } \\
\text { índice de } \\
\text { massa } \\
\text { muscular } \\
\text { esquelética foi } \\
\text { maior no grupo } \\
\text { de apenas } \\
\text { exercício do } \\
\text { que no grupo } \\
\text { somente } \\
\text { suplementação } \\
\text { de proteína e } \\
\text { significativame } \\
\text { nte maior no } \\
\text { grupo e } \\
\text { exercício } \\
\text { suplementação } \\
\text { protéica do que } \\
\text { nos apenas de } \\
\text { exercício ou } \\
\text { apenas de } \\
\text { suplementação } \\
\text { protéica. }\end{array}$ & $\begin{array}{l}\text { O efeito positivo da } \\
\text { suplementação de } \\
\text { proteína de soro de } \\
\text { leite, ingerida após } \\
\text { o exercício resistido } \\
\text { foi o aumento da } \\
\text { massa muscular e } \\
\text { força entre mulheres } \\
\text { japonesas idosas. }\end{array}$ \\
\hline $\begin{array}{l}\text { Chun-De Liao } \\
\text { et al. } \\
2017\end{array}$ & $\begin{array}{l}\text { Effects of } \\
\text { elastic } \\
\text { resistance } \\
\text { exercise on } \\
\text { body } \\
\text { composition } \\
\text { and physical } \\
\text { capacity in } \\
\text { older women } \\
\text { with } \\
\text { sarcopenic } \\
\text { obesity A } \\
\text { CONSORT- } \\
\text { compliant } \\
\text { prospective } \\
\text { randomized } \\
\text { controlled } \\
\text { trial }\end{array}$ & $\begin{array}{l}\text { Estudo } \\
\text { prospectiv } \\
\text { o e } \\
\text { randomiza } \\
\text { do, com } \\
\text { uma } \\
\text { análise de } \\
\text { intenção de } \\
\text { tratar. }\end{array}$ & $\begin{array}{l}\text { Identificar a eficácia } \\
\text { clínica do } \\
\text { treinamento } \\
\text { resistido elástico em } \\
\text { pacientes com } \\
\text { obesidade } \\
\text { sarcopênica. }\end{array}$ & $\begin{array}{l}\text { No pós-teste, } \\
\text { foi observada } \\
\text { uma diferença } \\
\text { significativa } \\
\text { entre os grupos } \\
\text { em massa livre } \\
\text { de gordura, } \\
\text { qualidade } \\
\text { muscular e } \\
\text { capacidade } \\
\text { física; e uma } \\
\text { correlação } \\
\text { significativa } \\
\text { foi encontrada } \\
\text { entre a da } \\
\text { alteração da maga } \\
\text { massa dernas a } \\
\text { das perna } \\
\text { velocidade da } \\
\text { marcha. Após } \\
\text { 12 semanas de } \\
\text { intervenção } \\
\text { elástica do } \\
\text { treinamento } \\
\text { resistido } \\
\text { elástico, } \\
\text { Grupo } \\
\text { Experimental } \\
\text { teve }\end{array}$ & $\begin{array}{l}\text { Os presentes dados } \\
\text { sugerem que o } \\
\text { exercício resistido } \\
\text { elástico exerceu } \\
\text { benefícios na } \\
\text { composição } \\
\text { corporal, qualidade } \\
\text { corporal e função } \\
\text { física em pacientes } \\
\text { com obesidade } \\
\text { sarcopênica. } \\
\text { Exercícios regulares } \\
\text { que incorporam o } \\
\text { treinamento } \\
\text { resistido devem ser } \\
\text { usados para atenuar } \\
\text { a perda de massa } \\
\text { muscular e prevenir } \\
\text { dificuldades físicas } \\
\text { em obesos com } \\
\text { sarcopenia. }\end{array}$ \\
\hline
\end{tabular}


significativame

nte menos

pacientes

exibindo

sarcopenia em

relação

ao

Grupo

Controle.

$\begin{array}{lll}\text { ZDZIEBLIK et } & \text { Collagen } & \text { Estudo } \\ \text { al. } & \text { Peptide } & \text { randomiza } \\ 2015 & \text { Supplementat do, duplo- } \\ & \text { ion in cego, } \\ & \text { Combination controlado } \\ & \text { With } & \text { por } \\ & \text { Resistance placebo. } \\ & \text { Training } & \\ & \text { Improves } \\ & \text { Body } & \\ & \text { Composition } \\ & \text { and Increases } \\ & \text { Muscle } \\ & \text { Strength in } \\ & \text { Elderly } \\ & \text { Sarcopenic } \\ & \text { Men: } \\ & \text { Randomised A } \\ & \text { Controlled } \\ & \text { Trial }\end{array}$

Avaliar a influência

da suplementação

protéica

exercício

pós-

peptídeos

colágeno versus pla

cebo na massa

muscular e na

função muscular

após treinamento

resistido em idosos

com sarcopenia.
O presente acordo com investigações anteriores, mostrando que o exercício resistido

melhora força, a massa sarcopenia. Compar livre de ados com o placebo, gordura, a os indivíduos do coordenação e grupo suplementado o controle com colágeno postural no mostraram um envelheciment aumento maior na o da massa livre de população.

Os peptídeos de colágeno aumentaram ainda mais os benefícios do treinamento resistido de três meses em indivíduos idosos gordura e força estudo está de muscular e redução maior na massa gorda. essenciais
Os resultados indicaram um aumento significativo da massa livre de gordura em todos os grupos $\mathrm{e}$ alterações na força muscular, sem diferenças entre grupos.

OS promover ganhos de massa muscular ao executar exercícios.

O treinamento resistido é uma maneira eficaz de aumentar a massa muscular e a força, independentemente da suplementação. Doses mais altas de alimentos ricos em proteínas são recomendadas para

$\begin{array}{ll}\text { Mathieu } & \text { The Effect of } \\ \text { Maltais, Joëlle } & \text { Resistance } \\ \boldsymbol{P} & \text { Training and } \\ \text { Ladouceur, Isab } & \text { Different } \\ \text { elle J Dionne. } & \text { Sources of } \\ 2016 & \text { Postexercise } \\ & \text { Protein } \\ & \text { Supplementat } \\ & \text { ion on } \\ & \text { Muscle Mass } \\ & \text { and Physical } \\ & \text { Capacity in } \\ & \text { Sarcopenic } \\ & \text { Elderly Men }\end{array}$

Estudo
randomiza
do, duplo-
cego,
controlado

Investigar os efeitos de um programa de exercícios resistidos de 16 semanas combinado com o consumo aminoácidos suficientes de pó comercial ou leite em pó sobre a massa muscular, capacidade física e funcional em homens idosos sarcopênicos.

$\begin{array}{lll}\text { CUNHA et al. } & \text { The Effects Estudo } \\ 2017 & \text { of Resistance randomiza } \\ & \text { Training do } \\ & \text { Volume on controlado. } \\ & \text { Osteosarcope } \\ & \text { nic Obesity in } \\ & \text { Older Women }\end{array}$

Analisar os efeitos do treinamento resistido realizado com 1 ou 3 séries por exercício nos parâmetros síndrome obesidade osteossarcopênica em mulheres idosas. 


\begin{tabular}{|c|c|c|c|c|c|}
\hline & & & & $\begin{array}{l}\text { pontuação em } \\
\text { força. }\end{array}$ & $\begin{array}{l}\text { induzindo melhorias } \\
\text { em comparação a } \\
\text { uma série. }\end{array}$ \\
\hline $\begin{array}{l}\text { VIANA et al. } \\
2018\end{array}$ & $\begin{array}{l}\text { Effect of a } \\
\text { resistance } \\
\text { exercise } \\
\text { program for } \\
\text { sarcopenic } \\
\text { elderly } \\
\text { women: } \\
\text { quasi- } \\
\text { experimental } \\
\text { study }\end{array}$ & $\begin{array}{l}\text { Estudo } \\
\text { quasi- } \\
\text { experiment } \\
\text { al (pré-pós } \\
\text { intervençã } \\
\text { o). }\end{array}$ & $\begin{array}{l}\text { Avaliar o impacto } \\
\text { de um programa de } \\
\text { exercícios com } \\
\text { carga progressiva } \\
\text { no desempenho } \\
\text { muscular } \\
\text { funcional de idosas } \\
\text { sarcopênicas. }\end{array}$ & $\begin{array}{l}\text { Esses } \\
\text { resultados } \\
\text { demonstraram } \\
\text { que o } \\
\text { treinamento a } \\
75 \% \text { foi capaz } \\
\text { de recrutar } \\
\text { unidades } \\
\text { motoras e, } \\
\text { nesse caso, } \\
\text { provavelmente } \\
\text { fibras do tipo I, } \\
\text { que são mais } \\
\text { evidentes em } \\
\text { indivíduos } \\
\text { sarcopênicos. }\end{array}$ & $\begin{array}{l}\text { O Programa de } \\
\text { Treinamento de } \\
\text { Resistência } \\
\text { Progressiva é capaz } \\
\text { de combater as } \\
\text { perdas de massa } \\
\text { muscular, força e } \\
\text { desempenho físico } \\
\text { em idosos } \\
\text { sarcopênicos. }\end{array}$ \\
\hline
\end{tabular}

Fonte: os autores

\section{DISCUSSÃO}

O envelhecimento vem acompanhado da sarcopenia, mais conhecida como fraqueza muscular. Após certa idade, essa enfermidade é um grande fator causador de incapacidade em idosos. Com isso, vários estudos relatando as sequelas causadas por essa patologia podem ser encontrados, assim como tratamentos experimentais para amenizar seus efeitos.

Viana et al (2018), ao avaliarem os impactos de um programa de exercícios com carga progressiva em mulheres idosas sarcopênicas, notaram que após doze semanas de exercício, três vezes por semana, houve aumento de massa magra, aumento de força no quadríceps e melhorias tanto no desempenho funcional como muscular.

Piastra et al (2018), ao fazerem um estudo sobre os efeitos de um programa de nove meses de atividade física adaptada, utilizando dois exercícios (programa esse baseado em treino de reforço muscular e treino de postura em mulheres idosas e sarcopênicas), observaram que ao final do programa as mulheres obtiveram aumento de força e massa muscular, gerando, desse modo, efeitos positivos tanto em relação à sarcopenia quanto em relação à postura.

Cunha et al (2018) realizaram um estudo para analisar os efeitos da atividade física contra a obesidade osteosarcopênica. Para isso, participaram do estudo sessenta e duas mulheres idosas que integravam um programa de doze semanas de treino de resistência três vezes por semana. As idosas foram divididas em 3 grupos: um grupo controle (GC), um grupo que fez uma série por dia de exercícios (G1), e um grupo que fez três séries de exercícios 
(G3). Ao final do estudo foi comprovado que apesar de o tempo de exercício de G3 ser pelo menos três vezes maior que G1, e G1 ser a alternativa mais atrativa entre as duas, quando se diz respeito ao tempo-eficiência, houve grandes mudanças entre o grupo G1 e G3 com relação à porcentagem de gordura corporal e força, com G3 possuindo os melhores resultados. Esse estudo comprovou que um período de treino de resistência de doze semanas é bastante efetivo para melhorar os fatores de risco da obesidade osteosarcopênica e que três séries geram melhores resultados que uma série de exercício durante esse período de tempo.

Ao conduzir um estudo em um centro de reabilitação, Liao et al (2017) analisaram os efeitos de um exercício de resistência elástica na composição corporal e na capacidade física em mulheres idosas portadoras de obesidade sarcopênica. Um total de quarenta e seis idosas, com idade média de sessenta e sete anos, foram divididas em dois grupos. Um grupo experimental (GE) treinou exercícios de resistência elástica por doze meses, e um grupo de controle (GC) não praticou o treino. Foram feitas medidas de composição corporal e qualidade muscular. Após o programa foram notadas diferenças entre a quantidade de massa livre de gordura entre os dois grupos, assim como a qualidade muscular e a capacidade física das idosas dos dois grupos. O número de idosas com sarcopenia diminuiu consideravelmente, assim como o número de idosas com dificuldades físicas. Além da melhoria física das idosas, esse estudo demonstrou que as mudanças na composição corporal estavam significativamente correlacionadas com a força muscular e a mobilidade física após o programa, mostrando que a perda de massa muscular está associada com o envelhecimento e o treinamento de resistência elástica é muito vantajoso para ganho de massa muscular e força em pessoas idosas.

Mori e Tokuda (2018) realizaram um estudo para observar os efeitos da ingestão da proteína whey na massa muscular e nas funções físicas de mulheres idosas saudáveis após a prática de treino de resistência. Esse estudo foi baseado em um programa de vinte e quatro semanas de suplementação nutricional ingerido após a prática de exercícios. Oitenta e uma mulheres com idade entre sessenta e cinco e oitenta anos foram divididas em três grupos: um grupo que praticou apenas exercícios de resistência (G1), outro que ingeriu apenas a suplementação (G2) e o terceiro que envolveu tanto a suplementação quanto o programa de exercícios de resistência (G3). Ao analisar os dados obtidos pré e pós-programa, pôde-se perceber que houve aumento no músculo esquelético dos grupos. O aumento foi significativamente maior em G1 do que em G2 e ainda maior em G3. Além disso, o grupo que relacionou a suplementação com exercícios obteve melhorias em firmeza, velocidade ao andar e maior ganho de massa muscular nos membros inferiores se comparado aos outros grupos, 
demonstrando que a ingestão de proteína whey após a prática de exercícios de resistência pode ser efetiva contra a sarcopenia em pessoas idosas.

Yamada et al (2018) analisaram os efeitos sinérgicos da prática de exercícios de resistência do peso corporal aliada à suplementação proteica com vitamina $\mathrm{D}$ no músculo esquelético em idosos sarcopênicos ou dinapênicos (perda de força e potência muscular causada pelo envelhecimento). Para esse estudo cento e doze idosos foram divididos em quatro grupos: um grupo de exercícios $(\mathrm{G} 1)$, um grupo de suplementação $(\mathrm{G} 2)$, um grupo controle (GC), e um grupo que combinou exercícios e suplementação (G3). O programa foi realizado em 12 semanas. O grupo G3 obteve resultados mais expressivos, aumentando a qualidade muscular e a força muscular de seus participantes dinapênicos e aumentando a massa muscular apendicular dos participantes sarcopênicos. Com isso, o estudo demonstrou que uma dieta de proteínas relacionada a exercícios físicos são de grande ajuda contra os efeitos da sarcopenia ou dinapenia, melhorando tanto a força quanto a massa muscular dos idosos. Porém, o autor considera esse estudo como tendo duas limitações que deveriam ser mencionadas: o tamanho das amostras que foram insuficientes nos subgrupos e alguns resultados que foram obtidos por ultrassonografia cujo método de medida é controverso. Mas, em geral os resultados obtidos foram satisfatórios.

Zdzieblik et al (2015) estudaram a influência do treino de resistência em combinação com uma suplementação de peptídeo colagenoso no aumento de força muscular em homens idosos sarcopênicos. Cinquenta e três idosos sarcopênicos com idade média de setenta e dois anos foram divididos em dois grupos e participaram de um programa de doze semanas de treinamento de resistência aliado à ingestão de peptídeo colagenoso (Grupo 1) ou sílica como placebo (Grupo 2). Massa magra, massa gorda e massa óssea foram medidas antes e depois do programa e a força isocinética do quadríceps foi medida durante a intervenção. Durante o estudo foi especulado que o momento em que se faz a suplementação, assim como a absorção cinética da proteína ingerida influenciam em sua eficácia. Rápida absorção e digestão cinética influenciam diretamente na hipertrofia muscular causada pelas proteínas. Ao final do estudo notou-se que todos os indivíduos mostraram maiores níveis de massa magra, massa óssea e força do quadríceps e níveis menores de massa gorda, sendo esses resultados ainda mais expressivos no grupo suplementado com peptídeo colagenoso, pois o colágeno é rico em glicina e arginina que são substâncias importantes para a síntese de creatina, cuja suplementação pode melhorar a massa e a função muscular no corpo humano. Esse estudo mostrou que uma dieta de peptídeo colagenoso combinado à prática de exercícios gera melhorias na composição corporal do idoso com sarcopenia. 
Dionne, Ladouceur e Maltais (2016) desenvolveram um estudo sobre o efeito do treino de resistência aliado à ingestão de proteínas pós-exercício na massa muscular e na capacidade física em homens sarcopênicos. Para esse estudo vinte e seis indivíduos foram divididos em três grupos que praticaram exercícios e ingeriram suplementos ricos em proteína pós-treino: proveniente de leite (Grupo 1), soja (Grupo 2) e leite de arroz (Grupo 3). Ao final de dezesseis semanas os dados demonstraram que houve aumento significativo na massa muscular e força nos participantes, demonstrando a importância de indivíduos com baixa massa muscular praticarem exercícios de resistência, além de indicar que pessoas idosas necessitam de um maior consumo de proteínas para obter um melhor impacto na força e massa muscular. Apesar dos ganhos gerais significativos o tratamento obteve baixa influência em relação à massa magra e ganhos na função física, pois os indivíduos eram sedentários e sarcopênicos.

Todos os estudos realizados com programas de exercícios físicos aliados à suplementação obtiveram resultados positivos contra os efeitos da sarcopenia, gerando melhora de vida para as pessoas idosas que participaram desses programas.

\section{CONCLUSÃO}

Através de uma revisão descritiva de literatura, foram revisados oito trabalhos cujos temas principais foram a sarcopenia em idosos com idade acima de sessenta anos e métodos para diminuição de seus efeitos e prevenção. Por meio dos trabalhos estudados pôdese observar que essa enfermidade chega com a idade, atingindo as pessoas idosas, causando fraqueza muscular e perda de massa muscular.

De acordo com os trabalhos inspecionados, alguns tratamentos aplicados foram bastante eficientes, em especial a prática de exercícios físicos três vezes por semana, trazendo diversos benefícios para a saúde do idoso, aumentando tanto a porcentagem de massa muscular quanto a força física e a diminuição da massa gorda. Diminuição da fraqueza, perda da dificuldade de andar, aumento de massa magra nos membros inferiores e melhor postura também foram pontos positivos obtidos pelas intervenções. Assim, esse tipo de tratamento se torna um meio de melhorar a qualidade de vida e as sequelas provenientes do envelhecimento e da sarcopenia.

Sendo assim, a participação efetiva dessa população em programas de exercícios físicos auxiliará na redução da sarcopenia e na consequente melhoria do desempenho nas AVD's e menores riscos à saúde. 


\section{REFERÊNCIAS}

CHODZKO-ZAJKO, W.; PROCTOR, D.; FIATARONE, S. M.; MINSON, C.; NIGG, C.; SALEM, G. Exercício e atividade física para idosos. Med Sci Sports Exerc. 2009; 41 (7): 1510-30.

CARDOSO, R. M. et al. Exercício resistido frente à sarcopenia: uma alternativa eficaz para a qualidade de vida do idoso. Revista Digital, Buenos Aires, v. 17, n. 169, 2012.

CRUZ-JENTOFT, A. J.; TRIANA, F. C.; GÓMEZ-CABRERA, M. C.; LÓPEZ-SOTO, A.; MASANÉS, F.; MARTÍN, P. M. A eclosão da sarcopenia: relatório preliminar do Observatório da Sarcopenia da Sociedade Espanhola de Geriatria e Gerontologia. Rev Esp Geriatr Gerontol. 2011; 46 (2): 100-10.

CUNHA, P. M. et al. The effects of resistance training volume on osteosarcopenic obesity in older women. Journal of sports sciences, v. 36, n. 14, p. 1564-1571, 2018.

FREITAS, E.V. Tratado de geriatria e gerontologia. 2. ed. Rio de Janeiro: Guanabara Koogan, 2006.

GARCIA, P. A.; DIAS, J. M. D.; DIAS, R. C.; SANTOS, P.; ZAMPA, C. C. Estudo da relação entre função muscular, mobilidade funcional e nível de atividade física em idosos residentes. Rev Bras Fisioter. 2011; 15 (1): 15-22.

GIELEN, E.; O’NEILL, T.; PYE, S. Endocrine determinants of incident sarcopenia inmiddleaged and elderly European men. Journal of Cachexia, Sarcopenia and Muscle 2015; 6: 242252.

GUEDES, D.; JUNIOR, T.; ROCHA, A. Treinamento personalizado em musculação. São Paulo: Phorte, 2008.

INOUYE, K.; SILVA, P..E.; IOST, P. S.; Octogenários e cuidadores: perfil sóciodemográfico e correlação da variável qualidade de vida. Texto \& Contexto Enfermagem, v. 17, n. 2, 2008.

LIAO, C. et al. Effects of elastic resistance exercise on body composition and physical capacity in older women with sarcopenic obesity: A CONSORT - compliant prospective randomized controlled trial. Medicine, v. 96, n. 23, 2017.

MALTAIS, M. L.; LADOUCEUR, J. P.; DIONNE, I. J. The effect of resistance training and different sources of postexercise protein supplementation on muscle mass and physical capacity in sarcopenic elderly men. Journal of strength and conditioning research, v. 30, $\mathrm{n}$. 6, p. 1680-1687, 2016.

MINISTÉRIO DA SAÚDE. Envelhecimento e saúde da pessoa idosa. Secretaria de Atenção à Saúde. Departamento de Atenção Básica. Brasília, 2006.

MIYAZAKI, R.; TAKESHIMA, T.; KOTANI, K. Exercise Intervention for Anti-Sarcopenia in Community-Dwelling Older People. J Clin Med Res., v. 8, n. 12, p. 848-853, 2016. 
MORI, H.; TOKUDA, Y. Effect of whey protein supplementation after resistance exercise on the muscle mass and physical function of healthy older women: a randomized controlled trial. Geriatrics \& gerontology international, v. 18, n. 9, p. 1398-1404, 2018.

NICASTRO, H., ZANCHI, N. E., LUZ, C. R.; LANCHA JR, A. H. Efeitos funcionais e morfológicos do exercício resistido na atrofia muscular esquelética induzida por desuso. Braz J Med Biol Res. 2011; 44 (11): 1070-9.

PARAHYBA, M. I. SIMÕES, C. C. S. A prevalência de incapacidade funcional em idosos no Brasil. Ciênc Saúde Coletiva. 2006;11(4):967-74.

PETERSON, M. D.; SEN, A.; GORDON, P. M. Influência do exercício resistido na massa corporal magra em adultos idosos: uma metanálise. Med Sci Sports Exerc. 2011; 43 (2): 249-58.

PIASTRA, G. et al. Effects of two types of 9-month adapted physical activity program on muscle mass, muscle strength, and balance in moderate sarcopenic older women. BioMed research international, v. 2018, 2018.

SILVA, T. A. A.; FRISOLI JR, A.; PINHEIRO, M. M.; SZEJNFELD, V. L. Sarcopenia associada ao envelhecimento: aspectos etiológicos e opções terapêuticas. Rev Bras Reumatol. v. 46, n.6, p.391-397, 2006.

VIANA, J. U. et al. Effect of a resistance exercise program for sarcopenic elderly women: quasi-experimental study. Fisioterapia em Movimento, v. 31, 2018.

WATERS, D. L.; BAUMGARTNER, R. N.; GARRY, P. J.; VELLAS, B. Vantagens de intervenções dietéticas, relacionadas a exercícios e terapêuticas para prevenir e tratar sarcopenia em pacientes adultos: uma atualização. Clin Interv Aging. 2010; 5: 259-70.

YAMADA, M. et al. Synergistic effect of bodyweight resistance exercise and protein supplementation on skeletal muscle in sarcopenic or dynapenic older adults. Geriatrics \& gerontology international, v. 19, n. 5, p. 429-437, 2019.

ZDZIEBLIK, Denise et al. Collagen peptide supplementation in combination with resistance training improves body composition and increases muscle strength in elderly sarcopenic men: a randomised controlled trial. British Journal of Nutrition, v. 114, n. 8, p. 1237-1245, 2015. 


\title{
EVALUACIÓN DE DESEMPEÑO Y ALINEAMIENTO ESTRATÉGICO: BASES PARA UNA FORMULACIÓN MÉTRICA
}

\author{
https://dx.doi.org/10.48097/2674-8673.2021n5p10
}

Julio Miranda Vidal ${ }^{1}$

\section{RESUMEN}

Los retos del desarrollo exigen que todos los actores de una nación converjan hacia un propósito común: un ideario nacional; en este intervienen tres actores fundamentales: El gobierno, la sociedad civil y las empresas. A los gobernantes les cabe la misión de formular las políticas públicas necesarias, a fin de generar las adecuadas condiciones para el logro de los objetivos y metas del ideario, el cual debe ser una monolítica expresión del soberano. A la sociedad civil, desde la individualidad, y desde sus organizaciones, participar activamente de las tareas que impone tamaño desafío. Las empresas, en su rol de producir y servir, deben alinear las estrategias al capital humano, de modo que el logro individual agregado cree valor organizacional sinergizado, esto impone exigentes tareas, desde adecuar los cuadros organizacionales, definir el contenido de los puestos y descriptores de cargo, todo en función de horizontes de largo plazo. Para monitorear el grado de cumplimiento de las expectativas del cargo con los resultados reales es necesario avanzar, con urgencia, hacia modelos de evaluación de desempeño de mayor objetividad y racionalidad que primen por sobre evaluaciones con importante grado de subjetividad.

Palabras clave: Alineamiento estratégico. Evaluación de desenpeño. Formulación métrica. Modelos de evaluación.

Data de submissão: 22/06/2021

Data de aprovação: 28/06/2021

\section{AVALIAÇÃO DE DESEMPENHO E ALINHAMENTO ESTRATÉGICO: BASES PARA UMA FORMULAÇÃO MÉTRICA}

\section{RESUMO}

Os desafios do desenvolvimento exigem que todos os atores de uma nação convirjam para um propósito comum: uma ideologia nacional. Três atores fundamentais intervêm nisso: o governo, a sociedade civil e as empresas. Os governantes têm a missão de formular as políticas públicas necessárias, a fim de gerar as condições adequadas para o cumprimento dos objetivos e metas da ideologia, que deve ser uma expressão monolítica soberana. A sociedade

\footnotetext{
${ }^{1}$ Universidad Mayor, Chile. Profesor de Liderazgo, Innovación, Administración y Gestión de Recursos Humanos, y Coordinador Línea Administración y Recursos Humanos de la Facultad de Emprendimiento y Negocios. Miembro del Panel de Expertos de ONU-PNUD-RedUnirse en Responsabilidad Social. E-mail: mirandavidal@gmail.com
} 
civil, desde a individualidade e de suas organizações, participa ativamente das tarefas que tal desafio impõe. As empresas, no seu papel de produzir e servir, devem alinhar estratégias com o capital humano, de forma que a conquista individual agregada crie valor organizacional sinérgico, isso impõe tarefas exigentes, desde adequar os organogramas, definir o conteúdo dos cargos e descritores cobrados, tudo com base em horizontes de longo prazo. Para acompanhar o grau de cumprimento das expectativas do cargo com os resultados reais é necessário avançar, com urgência, para modelos de avaliação de desempenho de maior objetividade e racionalidade que prevalecem sobre avaliações com significativo grau de subjetividade.

Palavras-chave: Alinhamento estratégico. Avaliação de desempenho. Formulação métrica. Modelos de avaliação.

\begin{abstract}
Development challenges demand that all actors in a nation converge towards a common purpose: a national ideology. Three actors are essential for this: the government, civil society and companies. Governments have the mission of formulating the necessary public policies in order to generate the adequate conditions for the fulfillment of the objectives and goals of the ideology, which must be a sovereign monolithic expression. Civil society, either individually or through its organizations, actively participates in the tasks that such a challenge imposes. Companies, in their role of producing and serving, must align strategies with human capital, so that the aggregated individual achievement creates synergistic organizational value. This imposes demanding tasks, from adapting the organization charts to defining the content of the positions and descriptors charged, all based on long-term horizons. In order to monitor the degree of fulfillment of the job's expectations with the actual results, it is urgently necessary to move towards performance evaluation models with greater objectivity and rationality that prevail over evaluations with a significant degree of subjectivity.
\end{abstract}

Keywords: Strategic alignment. Performance evaluation. Metric formulation. Assessment models.

\title{
INTRODUCCIÓN
}

El siglo XX puede entenderse como un "siglo bisagra" entre el período concluido con el fenómeno de la Revolución Industrial británica y la irrupción de las tecnologías de la información y las comunicaciones.

En este contexto, la gestión organizacional en todos sus ámbitos: público, privado y en entidades de la sociedad civil y de la educación, ha experimentado profundas transformaciones. Los conceptos de Dirección y Gerencia en los albores del siglo pasado son profundamente distintos a los que imperan hoy en las organizaciones.

Esa centuria fue capaz de producir grandes obras del genio humano, también, al menos en el mundo occidental, ha habido dos grandes guerras mundiales y otros tantos conflictos 
localizados, de diverso grado de conmoción. En el período se han usado, consumido y expoliado grandes masas de recursos naturales, muchos de ellos no renovables. Como consecuencia ha emergido con fuerza la disciplina de la Responsabilidad Social, la que ha madurado velozmente desde la filantropía y la cultura verde hasta un replanteamiento del orden civilizatorio, en íntima amalgama con la sustentabilidad de las actividades humanas presentes y futuras.

Es así como la Responsabilidad Social se ha planteado ambiciosos propósitos, tal como lo refleja la Declaración de Panamá de 2012, producto de la Cumbre de expertos patrocinada por el Programa de Desarrollo de las Naciones Unidas: "Nos comprometemos a trabajar en el cultivo, investigación, enseñanza, divulgación y aplicación de los principios de la Responsabilidad Social, para contribuir al desarrollo humano sustentable, en plena armonía con nuestros pueblos y el ambiente.” (DE LA CORTE Y MIRANDA, 2012).

De este modo, los desafíos del management pasan necesariamente por el colosal reto de la Creación de Valor en plena armonía con las ciudadanías y el ambiente. Esto obliga a precisar que el crear valor trasciende objetivos basales clásicos: en las empresas, generar excedentes y solidez patrimonial; en el ámbito público, externalidades positivas; en la sociedad civil, reivindicaciones colectivas. En todos estos casos la sustentabilidad de las estructuras organizacionales es hoy un pilar insoslayable, es decir, la preocupación e incidencia en el bien común proyectado en un horizonte de largo plazo y de carácter global.

Toda organización sin considerar el equipo humano es una simple concurrencia y coexistencia de diversos activos inertes, que no pueden movilizarse, producir ni crear sin la intervención del genio y talento humanos.

Estas reflexiones nos llevan a un punto central en el debate contemporáneo y en la cosmovisión organizacional, la relevancia indesmentible del accionar humano en la dinámica social. Esto pone a este genuino "patrimonio humano" en simetría con el patrimonio económico-financiero de la entidad. Es decir, el valor creado es función de ambos conglomerados, y sus beneficiarios son la empresa, como colectivo humano, los clientes o usuarios, proveedores y la comunidad y el ambiente.

"Crear valor" puede entenderse con meridiana claridad desde lo intelectual, sin embargo, crear valor en el mundo real exige energía, esfuerzos y competencias complejas. De no ser así no habría empresas que fracasan, proyectos frustrados o sociedades inestables, e incluso estados fallidos.

En la actualidad se manejan variadas expresiones y denominaciones para referirse a "las personas" desde la óptica de la organización: gestión de recursos humanos, gestión de 
personas, gestión del talento, administración de recursos humanos, incluso unas tan antiguas como administración de personal. Para nuestros efectos, y entendido el contexto, usaremos a lo largo del texto la expresión "gestión de personas", advirtiendo que no es nuestro objeto expreso profundizar en la etimología, ámbito, diferencias y alcances de los términos citados precedentemente.

En consecuencia, nuestra preocupación se centrará en la gestión de personas, en el plano de la creación de valor organizacional y en el contexto de la armonía entre objetivos organizacionales, evaluación de desempeño y recompensa. Para estos efectos, el vocablo estratégico tendrá dos alcances fundamentales: el primero, se refiere a propósitos de largo plazo y, el segundo, a los factores y circunstancias que pueden crear o destruir patrimonio organizacional. Y, por otra parte, el foco está orientado a la concepción de una noción métrica para evaluar el desempeño y, como consecuencia, la recompensa asociada a los diferentes niveles de evaluación de desempeño medido.

¿Por qué le asignamos tal relevancia a la relación desempeño-creación de valor? La respuesta emana prácticamente espontánea a partir de las ideas presentadas en los párrafos precedentes. El constructo humano, como fenómeno general, responde al ordenamiento orientado al bien común sustentable. Así entonces, el valor organizacional creado, expresado en términos agregados, es el valor social creado, y éste debe impulsar el desarrollo humano de la sociedad como el mayor de los conglomerados o agrupación de individuos.

Entonces, la gestión de personas en la organización es uno de los ladrillos que se sumará al bienestar general del orden humano. Se infiere, entonces, que la gestión de la organización individual forma parte de la gran retícula de la sociedad. En otras palabras, cuando la gestión individual de la empresa es exitosa ésta aporta valor a la construcción de la sociedad en su conjunto. Parafraseando a Rousseau, esta suerte de Contrato Social sobre el que opera la organización, no sólo está concebido para beneficiar a los stakeholders más evidentes, sino que es verdaderamente un agente de cambio, con dinámica propia y buscando una perfecta sincronía con su ambiente.

Desde otra perspectiva, el desempeño superior del ocupante de un cargo, cuyo contenido, objetivos y funciones están alineados con la estrategia de la empresa, crea valor para ésta; y una adecuada relación entre compensación y rendimiento genera escenarios propicios para el logro de excedentes empresariales y, adicionalmente, es un factor clave para el establecimiento de un clima organizacional de orden superior. 
Este trabajo es la primera fase de una línea de investigación, que busca proponer un Modelo de Estructuramiento de Estrategia Corporativa y Capital Humano, en este caso abordando alineamiento y compensación variable.

\section{Alineando estrategia y contenido de cargos}

Al formular estrategias organizacionales uno de los aspectos centrales es la formulación de objetivos y metas $^{2}$, en íntima relación con la declaración de la Visión institucional. Asimismo, el rol y el ejercicio propio del quehacer empresarial quedan condensados en la definición de su Misión.

Lo señalado gatilla la revisión y reformulación del cuadro organizacional de la entidad, por cuanto la verticalidad (jerarquía, autoridad y dependencia) y la horizontalidad (división del trabajo), deben diseñarse de modo tal que el organigrama también esté alineado a la estrategia corporativa. La concepción de esto se observa en el Cuadro $\mathrm{N}^{\mathrm{o}} 1$, en él se aprecia la secuencia a seguir, desde las definiciones estratégicas hasta la evaluación de desempeño y compensación.

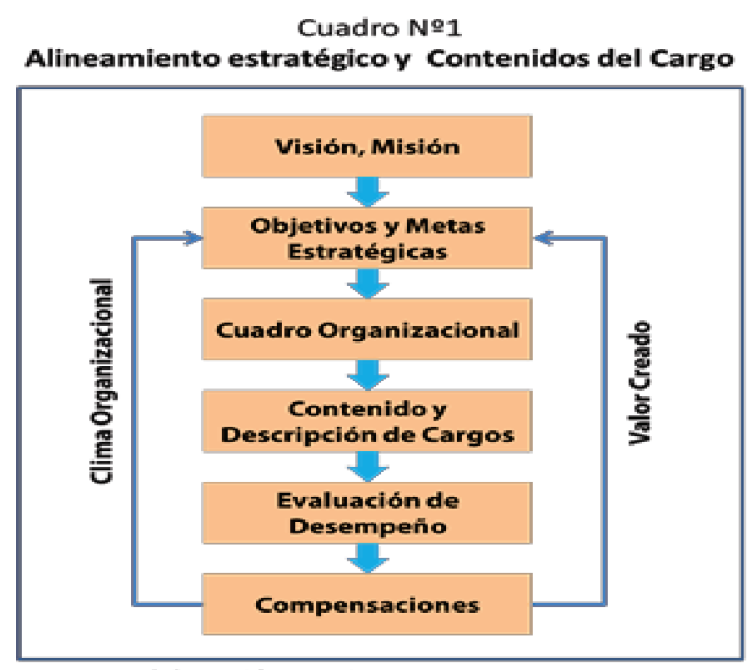

Fuente: Elaboración Propia.

Alineación de la estrategia al capital humano implica colinealidad de propósitos, es decir, si la empresa declara su Visión y Misión, es apropiado también declarar visiones y misiones en las unidades de departamentalización, con esto se consigue que cada unidad trabaje con una brújula propia en función del curso de navegación institucional. Veamos el siguiente ejemplo: La Junta Nacional de Cuerpos de Bomberos (JNCB) redefinió su Visión (BRAVO Y MIRANDA, 2009a) como "Ser reconocida por los Cuerpos de Bomberos de

\footnotetext{
2 Para efectos de este trabajo entenderemos a las metas como "objetivos cuantificados". Precisión de suma relevancia, pues cuantificar es un paso necesario para establecer métricas formales.
} 
Chile como un organismo de servicio de alta calidad en la asignación de recursos, apoyo técnico y formación integral de bomberos. Asimismo, aspira a ser el referente de la actividad de Bomberos de Chile ante el estado y la comunidad nacional e internacional". Al mismo tiempo definió la Visión para sus unidades departamentales (Organigrama), veamos los casos de la Dirección Ejecutiva: "Transformar a la JNCB en una organización que, con una fuerte vocación de servicio, administre con la mayor probidad y eficiencia los recursos que opera para el cumplimiento de los objetivos institucionales" y de la Subdirección de Finanzas: "Ser reconocida por su solidez técnica, probidad, transparencia, compromiso con el control y por el uso de los recursos en estricta correlación con las políticas superiores de JNCB".

Como se colige del ejemplo, las máximas declaraciones estratégicas de la organización, plasmadas en la Visión y Misión, se desagregaron en declaraciones análogas, y supeditadas a las institucionales, en las unidades departamentalizadas que operan cada ámbito de la JNCB. Asimismo, la institución definió (BRAVO Y MIRANDA, 2009b) sus objetivos, metas, estrategias, programas, responsables, plazos y medidas de evaluación (KPI) para darle cauce material a las declaraciones, así también cada unidad organizacional queda en condiciones de definir sus propios parámetros análogos. Es decir, en el caso, cada unidad de responsabilidad adopta su específico curso de navegación alineado al curso institucional.

Respecto de contenido de cargos, tomemos el ejemplo de la Subdirección de Finanzas del caso en comento. El primer factor declarado es la "solidez técnica", en consecuencia, serán elementos clave de quien ejerza tal función aspectos como el dominio de finanzas de largo y corto plazo, análisis financiero, gestión de tesorería, legislación aplicable como de mercado de valores, laboral e impositivo. El segundo factor es la "probidad", esto pone el acento en algunos requisitos de ingreso, pero por sobre todo en una sólida ética profesional durante el ejercicio del cargo. El tercer factor es la "transparencia", esto se centra en la continua y permanente existencia de una accountability a disposición de stakeholders externos e internos, lo que obliga a la mantención actualizada de reportes y registros conforme a la normativa y prácticas profesionales en curso. El cuarto factor es el "compromiso con el control", refiriéndose al amplio alcance de la expresión, tales como verificaciones y pruebas permanentes, análisis de desviaciones y brechas, medidas correctivas y su adecuada y oportuna exposición. El quinto factor "uso de los recursos en estricta correlación con las políticas superiores..."da cuenta de la subrogación a las declaraciones institucionales y define, entonces, los márgenes de autonomía y dependencia de la posición y se relaciona directamente con lo declarado por la JNCB en la Visión como “...organismo de servicio de alta calidad en la asignación de recursos...". 
El caso ilustra cómo se diseña y materializa el alineamiento entre estrategia y contenido de cargos, y expresa con meridiana claridad la metodología a seguir por directivos, gerentes y consultores en las organizaciones.

\section{Evaluación de desempeño}

En esta materia se dispone de un inventario de métodos, conocidos en su mayoría por directores y gerentes de recursos humanos. Dessler, G. y Varela, R. (2011) mencionan: Método de Escala de Puntuación Gráfica, Método de Clasificación Alterna, Método de Comparación con Pares, Método de Distribución Forzada, Método del Incidente Crítico, Escalas de Clasificación Basadas en el Comportamiento. Chiavenato, I. (2011) también considera algunos tales como el Método de Investigación de Campo y el Método de Frases Descriptivas. Estos y otros contienen, en mayor o menor medida, un elemento que complica su aceptación por muchos gerentes: la constante presencia de la subjetividad y la dificultad para que esta sea acotada. Este último aspecto abre un escenario de análisis e investigación, tras la búsqueda de nuevas proposiciones orientadas a medir el grado de cumplimiento de las principales actividades de un cargo, hecho de suma importancia a la luz de los antecedentes precedentemente expuestos, por cuanto constituyen el insumo para medir down-top el grado de cumplimiento a los propósitos estratégicos de la empresa.

Una dura tarea es evaluar el desempeño teniendo como referencia la cuantificación de fenómenos cualitativos. Es decir, cómo es posible medir actos vinculados a la conducta, en particular en el ambiente laboral. Ante esto, nos vemos en la obligación de recurrir al apoyo de herramientas matemáticas y estadísticas, para articular algún tipo de cimiento sobre el que construir una proposición.

\section{Descripción de cargo y funciones operacionales nucleares}

Son variados los continentes que pueden expresar lo que se conoce como Descriptor de Cargo, hay formatos básicos y complejos, transversales y específicos, también existen los desarrollados expresamente por la organización, considerando su realidad y circunstancias. Pero en todos ellos merece un acápite singular lo relativo a las actividades principales del cargo, que en adelante denominaremos "Funciones Operacionales Nucleares (FON)". Para efectos de la proposición esta nomenclatura tiene un sentido preciso, hecho que permite comprender sus características y alcance. Una dura tarea es evaluar el desempeño teniendo como referencia la cuantificación de fenómenos cualitativos. 
Ilustraremos el núcleo o razón de ser fundamental de un cargo, en el ordenamiento organizacional, con la expresión Core Position; con esto intentamos identificar la esencia del cargo, su columna vertebral, en el concierto empresa. Para satisfacer esta noción es esencial, conforme a lo señalado, establecer, tal como en el caso presentado (JNCB), cuál es la naturaleza de la posición, mediante la desagregación de la Visión de la unidad departamental.

Una vez hecho lo anterior, es decir, identificado el Core Position, entonces, el paso siguiente es la enunciación de las Funciones Operacionales Nucleares (FON), estas deben cumplir ciertos requisitos formales para ser construidas, los que se observan en el Cuadro $\mathrm{N}^{\circ}$ 2.

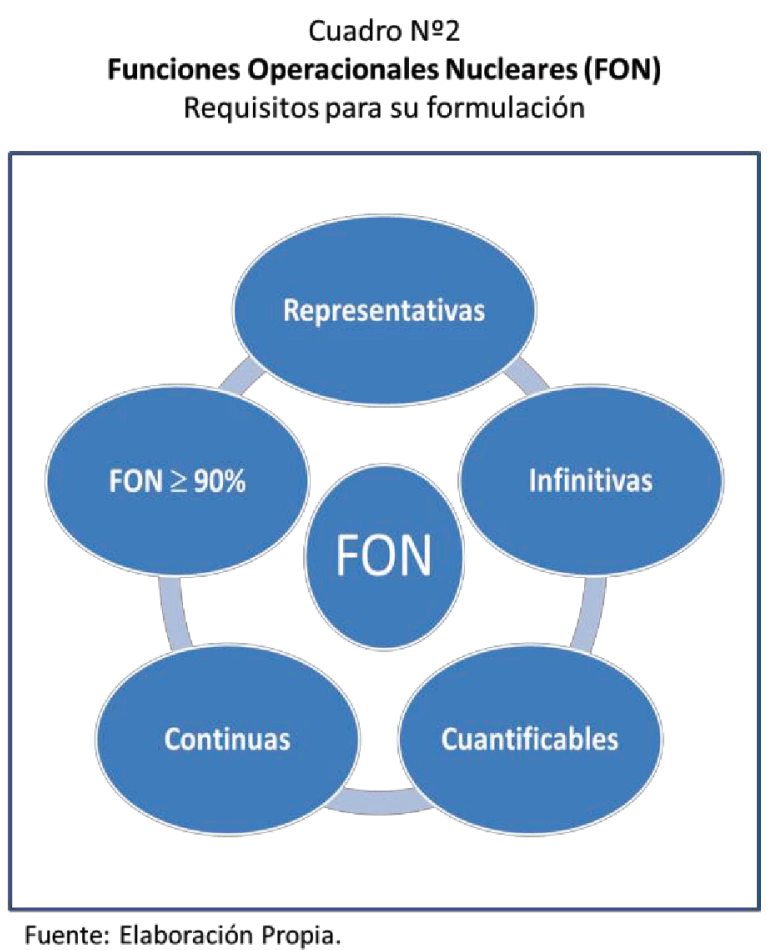

Un primer requisito a satisfacer es que una FON debe ser representativa a plenitud del Core Position del cargo, esto implica una total identificación con su rol de aportante de valor a la organización. Segundo requisito, exige que su formulación (redacción) debe ser en infinitivo, esto obliga a representar una FON como un verbo, esto es, indica una acción, concreta y diferenciable con total claridad de otra. Tercer requisito, toda FON debe ser cuantificable y susceptible de ser representada en una escala estandarizada y de comprensión general, una escala centesimal $(0 \%-100 \%)$ funciona perfectamente, pues permite comparar, ponderar y mezclar. Cuarto requisito, su propiedad "cuantificable" (tercer requisito), debe permitir que una FON pueda representarse como una función matemática continua. Quinto requisito, conforme veremos, los ensayos realizados nos aconsejan que las FON de un cargo 
no excedan de cinco (5) y que desde el prisma de la organización éstas acumulen al menos el 90\% del Core Position del cargo, debidamente ponderadas y presentadas en el descriptor del cargo en estricto orden de prelación $\left(\mathrm{FON}_{1}>\mathrm{FON}_{2}>\mathrm{FON}_{3}>\mathrm{FON} 4>\mathrm{FON}_{5}\right)$; así, en caso de existir otras funciones del cargo (Funciones Operacionales Orbitales, FO2) estas deben acumular el 10\% restante. Desde un punto de vista gerencial monitorear hasta el noveno $\left(9^{\circ}\right)$ decil representa una robusta herramienta de gestión. Es decir, la acumulación de las FON será:

$\sum \mathrm{FON}_{\mathrm{j}} \geq 90 \%$ donde $1 \leq \mathrm{j} \leq 5$

Cada FON se evaluará con su propia "variable de evaluación” o variable independiente $\left(\mathrm{v}_{\mathrm{j}}\right)$, la que alcanzará valores característicos de la FON producto de las acciones o transacciones del ocupante del cargo, y será evaluada como variable dependiente en escala centesimal (0\%-100\%), como medida de cumplimiento o de "desempeño" (EDI) para la FON en particular, esto es:

$$
\operatorname{EDI}_{\mathrm{FONj}}=\mathrm{f}\left(\mathrm{v}_{\mathrm{j}}\right)
$$

Donde "f" representa la expresión funcional y EDI la "evaluación de desempeño" para la $\mathrm{FON}_{\mathrm{j}}$. Al combinar las FON obtenemos la "evaluación de desempeño conjunta" (EDC), esto es la calidad global en el cumplimiento del cargo:

$$
\mathrm{EDC}=\Sigma \mathrm{EDI}_{\mathrm{FONj}} \mathrm{x} \mathrm{p}_{\mathrm{j}} \text { con } 1 \leq \mathrm{j} \leq 5
$$

\section{Política de evaluación de desempeño}

Aquí la proposición introduce el concepto de "Política de Evaluación de Desempeño" (PED), que representa el consenso de la Administración respecto de la forma de medir el grado de cumplimiento para los distintos cargos y sus respectivas FON. Este concepto constituye una respuesta a la aspiración directiva de eliminar o reducir la subjetividad en la evaluación de desempeño, la que queda acotada hasta la definición y formulación organizacional de la PED, de este modo las "fuentes" de subjetividad de la proposición claramente identificadas son:

1. La definición de las FON del cargo;

2. La ponderación (pj) asignada a cada FON; y

3. La definición funcional de la PED.

Una vez que la empresa ha definido completamente su política, de allí en adelante, los resultados de la evaluación de desempeño no pueden sino adoptar uno y sólo un resultado a determinados niveles de cumplimiento de las FON de cada cargo, y pueden ser convertidos en 
"aplicaciones" regulares en los sistemas de información, generando indicadores y reportes de una amplia gama. Es decir, los resultados obtenidos son comparables homogéneamente y operan como un índice de evolución; característica de gran relevancia, ya que permite entregar feedback (para la mejora y positivo), efectuar rotaciones de cargos, promociones, necesidades de capacitación y decidir desvinculaciones.

\section{Representación funcional}

La expresión concreta de una PED queda plasmada en una expresión gráfica y en un conjunto de funciones y ecuaciones.

Para ilustrar esta última fase, veamos el siguiente caso: Una empresa desea evaluar el desempeño de su Subgerente de Finanzas. El cargo, según la empresa, contribuye al alineamiento con las siguientes actividades, que ha definido como FON del cargo, situación que se observa en el Cuadro $\mathrm{N}^{\circ} 3$ :

\section{Cuadro №3}

Subgerente de Finanzas

Definición de la empresa de sus FON

$\Sigma F O N j \geq 90 \%$

\begin{tabular}{|c|l|c|}
\hline FON & \multicolumn{1}{|c|}{ DESCRIPCIÓN } & PONDERACIÓN \\
\hline FON $_{1}$ & $\begin{array}{l}\text { Mantener ciclo de caja en la } \\
\text { condición (Período medio de } \\
\text { cuentas por cobrar) } \leq \text { (Período } \\
\text { medio de cuentas por pagar) }\end{array}$ & $30 \%$ \\
\hline FON $_{2}$ & $\begin{array}{l}\text { Contratar deuda de corto plazo } \\
\text { del sistema financiero con tasas } \\
\text { (t) que cumplan t } \leq \text { t media de } \\
\text { mercado para operaciones } \\
\text { similares de los seis (6) últimos } \\
\text { meses }\end{array}$ & $25 \%$ \\
\hline FON & $\begin{array}{l}\text { Pagar a los Proveedores Clave } \\
\text { (definidos por la empresa) con } \\
\text { un máximo de 15 días de } \\
\text { retardo respecto de la fecha } \\
\text { nominal de facturas }\end{array}$ & $20 \%$ \\
\hline FON & & \\
\hline FON & & \\
\hline & D5... & $10 \%$ \\
\hline
\end{tabular}

Fuente: Elaboración Propia.

Para ilustrar esta tarea tomemos la $\mathrm{FON}_{1}$ del caso y veamos cómo la empresa ha definido evaluar el desempeño del ocupante del cargo. Esta función da cuenta del calce (o descalce) de la tesorería. Asumamos que para la empresa es relevante disponer de un calce o días a favor siempre y cuando éste sea mayor o igual a 40 días, en este negocio, a nivel de industria, es extremadamente difícil obtener calces por sobre los 60 días. Se reúnen las 
gerencias y después de un acalorado debate llegan a un acuerdo, éste es informado al Comité Ejecutivo del Directorio, facultado para aprobar o rechazar. Finalmente sale humo blanco y se aprueba la propuesta de evaluación de desempeño para la $\mathrm{FON}_{1}$ (esto que planteamos constituye una simplificación de la realidad, pues llegado el caso se presenta la PED para todas las posiciones de la empresa). La medida aprobada, en forma gráfica, queda expresada así:

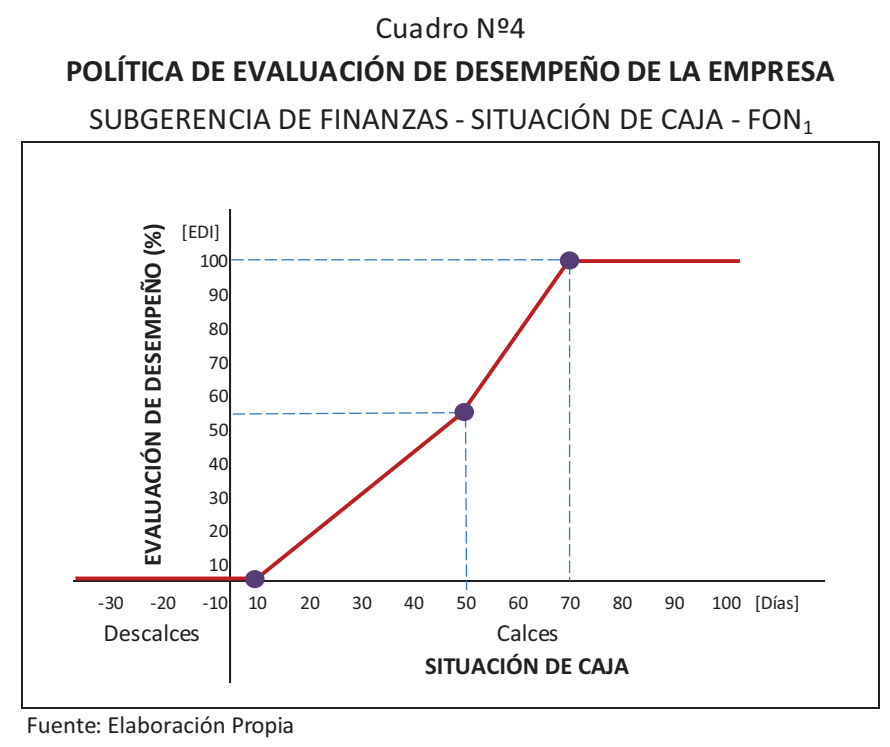

Una primera observación, para la construcción de la política, es que se propone trabajar con segmentos lineales; por dos razones, la primera, evita la formulación de polinomios y, la segunda, las funciones lineales son de cálculo rápido y de programación sencilla.

El número de funciones dependerá de los intervalos que definan la política y la valoración (eje de ordenadas) que se quiera dar a los diferentes niveles de logro de la variable de evaluación (eje de abscisas).

En forma analítica, la política se expresa:
$\mathrm{EDI}=0$
$\mathrm{Si} \quad \mathrm{D} \leq 10$
$\mathrm{EDI}=(55 / 40) \times \mathrm{D}-(55 / 4)$
Si $\quad 10<\mathrm{D} \leq 50$
$\mathrm{EDI}=(45 / 20) \times \mathrm{D}-(115 / 2)$
Si $\quad 50<\mathrm{D} \leq 70$
$\mathrm{EDI}=100$
Si $\quad \mathrm{D}>70$

Nótese que la pendiente de la función lineal correspondiente al intervalo [50;70] es mayor que la pendiente la función del intervalo $[10 ; 50]$, de modo que un incremento 
marginal de la variable evaluadora en éste último intervalo es mayor que si se produce en aquel. En otras palabras, se premia a tasas mayores el crecimiento unitario a partir de $\mathrm{D}=50$, lo que constituye un claro incentivo para el ocupante del cargo.

\section{CONCLUSIONES}

La Evaluación de Desempeño y los Descriptores de Cargo mediante la Metodología "EDAE Corporate $@$ ” representan un claro avance en el sentido de reducir y controlar la subjetividad en la medición de los resultados de los ocupantes de cargos en la organización.

Como se aprecia, a lo largo de la proposición, EDAE Corporate $₫$ es una herramienta al servicio de los propósitos estratégicos de la empresa, toda vez que se aplique la metodología a plenitud. Implementaciones parciales podrían producir sesgos y complicar aún más la situación organizacional en materia de gestión de personas.

EDAE Corporate $₫$ también es la puerta de entrada hacia el otorgamiento y la determinación de compensaciones variables con fuertes niveles de correlación con las expectativas de la empresa (resultados) respecto de la gestión de cada una de las posiciones.

El hecho de acotar los grados de subjetividad en la evaluación de desempeño, hasta la puesta en vigor de la política, representa un avance sustantivo, pues a partir del momento de su aplicación los resultados son independientes de quien efectúe la evaluación.

La Metodología EDAE Corporate $₫$ es aplicable a todo tipo de puestos, generadores o no de ingresos, de implícita naturaleza cuantitativa o no; la herramienta siempre ofrece una oportunidad de cuantificar aspectos cualitativos.

Asimismo, es aplicable en diversos sectores de la actividad económica, del mismo modo que se puede emplear en entidades públicas como en organizaciones sin fines de lucro.

Aún con estas apreciaciones, EDAE Corporate $@$ es una proposición que resuelve sólo una fracción de la problemática de gestión de personas. Resta mucho que avanzar en este campo. Mientras más sofisticadas sean nuestras actividades tendremos que enfrentar nuevos retos en materia de recursos humanos.

\section{REFERENCIAS}

BRAVO, P.; MIRANDA, J. JNCB, Plan Estratégico Institucional, Estructura General. B\&M Servicios Corporativos, Documento de Trabajo. Santiago. 2009a. 
BRAVO, P.; MIRANDA, J. JNCB, Implementación de Planificación Estratégica Institucional, Fase II, Diagnóstico Organizacional. B\&M Servicios Corporativos, Documento de Trabajo. Santiago. 2009b.

CHIAVENATO, I. Administración de Recursos Humanos. El capital humano en las organizaciones. McGraw-Hill. 9ª Edición. México. 2011.

DAVID, F. Conceptos de Administración Estratégica. Pearson Educación. $11^{\mathrm{a}}$ Edición. México. 2008.

DE LA CORTE, J.; MIRANDA, J. Declaración de Panamá Sobre Responsabilidad Social, Oportunidades y Desafíos. De La Corte \& Miranda. Santiago-Sevilla. 2012.

DESSLER, G.; VARELA, R. Administración de Recursos Humanos. Pearson Educación. $5^{\text {a }}$ Edición. México. 2011.

FRANCÉS, A. Estrategia y Planes Para la Empresa Con el Cuadro de Mando Integral. Pearson Educación. 1 ${ }^{\mathrm{a}}$ Edición. México. 2006.

GARCÍA, L.; GARCÍA, J. Impacto de la Inversión en Capital Humano Sobre el Valor Empresarial. Revista Latinoamericana de Administración. No 51, pp. 15-26. 2012.

HODGE, B. J. et al. Teoría de la Organización. Un Enfoque Estratégico. Pearson Educación.

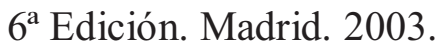

MIRANDA, J. Gestión de Personas. Herramientas Cuantitativas Aplicadas a Compensaciones. Revista Científica "Teoría, Enfoques y Aplicaciones en las Ciencias Sociales", No 5, pp. 107-116. 2010.

MONDY, R. Administración de Recursos Humanos. Pearson Educación. 11 a Edición. México. 2010.

STREBEL, P. et al. Gestión del Cambio. ¿Por Qué los Empleados se Resisten al Cambio? Deusto. $1^{\text {a }}$ Edición. Buenos Aires. 2004.

VALLE, R. La Gestión Estratégica de los Recursos Humanos. Pearson Educación. 2a Edición. Madrid. 2004.

WHEELEN, T.; HUNGER, J. Administración Estratégica y Politica de Negocios. Conceptos y Casos. Pearson Prentice Hall. 10 Edición. México. 2007. 


\title{
EVALUACIÓN DE DESEMPEÑO Y ALINEAMIENTO ESTRATÉGICO: BASES PARA UNA FORMULACIÓN MÉTRICA
}

\author{
https://dx.doi.org/10.48097/2674-8673.2021n5p09
}

Julio Miranda Vidal ${ }^{1}$

\section{AVALIAÇÃO DE DESEMPENHO E ALINHAMENTO ESTRATÉGICO: BASES PARA UMA FORMULAÇÃO MÉTRICA ${ }^{2}$}

\begin{abstract}
RESUMO
Os desafios do desenvolvimento exigem que todos os atores de uma nação convirjam para um propósito comum: uma ideologia nacional. Três atores são fundamentais para isso: o governo, a sociedade civil e as empresas. Os governantes têm a missão de formular as políticas públicas necessárias, a fim de gerar as condições adequadas para o cumprimento dos objetivos e metas da ideologia, que deve ser uma expressão monolítica soberana. A sociedade civil, seja individualmente ou através de suas organizações, participa ativamente das tarefas que tal desafio impõe. As empresas, no seu papel de produzir e servir, devem alinhar estratégias com o capital humano, de forma que a conquista individual agregada crie valor organizacional sinérgico. Isso impõe tarefas exigentes, desde adequar os organogramas, definir o conteúdo dos cargos e descritores cobrados, tudo com base em horizontes de longo prazo. Para acompanhar o grau de cumprimento das expectativas do cargo com os resultados reais é necessário avançar, com urgência, para modelos de avaliação de desempenho de maior objetividade e racionalidade que prevaleçam sobre avaliações com significativo grau de subjetividade.
\end{abstract}

Palavras-chave: Alinhamento estratégico. Avaliação de desempenho. Formulação métrica. Modelos de avaliação.

Data de submissão: 22/06/2021

Data de aprovação: $28 / 06 / 2021$

\section{RESUMEN}

Los retos del desarrollo exigen que todos los actores de una nación converjan hacia un propósito común: un ideario nacional; en este intervienen tres actores fundamentales: El gobierno, la sociedad civil y las empresas. A los gobernantes les cabe la misión de formular las políticas públicas necesarias, a fin de generar las adecuadas condiciones para el logro de

\footnotetext{
${ }^{1}$ Universidad Mayor, Chile. Profesor de Liderazgo, Innovación, Administración y Gestión de Recursos Humanos, y Coordinador Línea Administración y Recursos Humanos de la Facultad de Emprendimiento y Negocios. Miembro del Panel de Expertos de ONU-PNUD-RedUnirse en Responsabilidad Social. E-mail: mirandavidal@gmail.com

2 Tradução do Prof. Eronildo Ferreira, Docente da Faculdade Metropolitana da Grande Recife. E-mail: proferon100@gmail.com
} 
los objetivos y metas del ideario, el cual debe ser una monolítica expresión del soberano. A la sociedad civil, desde la individualidad, y desde sus organizaciones, participar activamente de las tareas que impone tamaño desafío. Las empresas, en su rol de producir y servir, deben alinear las estrategias al capital humano, de modo que el logro individual agregado cree valor organizacional sinergizado, esto impone exigentes tareas, desde adecuar los cuadros organizacionales, definir el contenido de los puestos y descriptores de cargo, todo en función de horizontes de largo plazo. Para monitorear el grado de cumplimiento de las expectativas del cargo con los resultados reales es necesario avanzar, con urgencia, hacia modelos de evaluación de desempeño de mayor objetividad y racionalidad que primen por sobre evaluaciones con importante grado de subjetividad.

Palabras clave: Alineamiento estratégico. Evaluación de desenpeño. Formulación métrica. Modelos de evaluación.

\begin{abstract}
Development challenges demand that all actors in a nation converge towards a common purpose: a national ideology. Three actors are essential for this: the government, civil society and companies. Governments have the mission of formulating the necessary public policies in order to generate the adequate conditions for the fulfillment of the objectives and goals of the ideology, which must be a sovereign monolithic expression. Civil society, either individually or through its organizations, actively participates in the tasks that such a challenge imposes. Companies, in their role of producing and serving, must align strategies with human capital, so that the aggregated individual achievement creates synergistic organizational value. This imposes demanding tasks, from adapting the organization charts to defining the content of the positions and descriptors charged, all based on long-term horizons. In order to monitor the degree of fulfillment of the job's expectations with the actual results, it is urgently necessary to move towards performance evaluation models with greater objectivity and rationality that prevail over evaluations with a significant degree of subjectivity.
\end{abstract}

Keywords: Strategic alignment. Performance evaluation. Metric formulation. Assessment models.

\title{
INTRODUÇÃO
}

O século 20 pode ser entendido como um "século de articulação" entre o período concluído com o fenômeno da Revolução Industrial britânica e o surgimento das tecnologias de informação e comunicação.

Nesse contexto, a gestão organizacional nas esferas pública, privada e em entidades da sociedade civil e de educação, passou por profundas transformações. Os conceitos de Direção e Gestão no início do século passado são bem diferentes daqueles que prevalecem nas organizações atuais. 
Nesse século o homem foi capaz de produzir grandes obras, assim como, pelo menos no mundo ocidental, duas grandes guerras mundiais e tantos conflitos localizados, de graus variados de comoção. Nesse período, grandes quantidades de recursos naturais, muitos deles não renováveis, foram usados, consumidos e saqueados. Como consequência, a disciplina da Responsabilidade Social surgiu com força e rapidamente amadureceu da filantropia e da cultura verde para um repensar da ordem civilizacional, em íntima fusão com a sustentabilidade das atividades humanas presentes e futuras.

Assim, a Responsabilidade Social propôs metas ambiciosas, refletidas na Declaração do Panamá de 2012, fruto da Cúpula de Peritos, patrocinada pelo Programa das Nações Unidas para o Desenvolvimento: “Comprometemo-nos a trabalhar no cultivo, na pesquisa, no ensino, na divulgação e aplicação dos princípios da Responsabilidade Social, para contribuir para o desenvolvimento humano sustentável, em plena harmonia com nossos povos e o meio ambiente.” (DE LA CORTE Y MIRANDA, 2012).

Deste modo, os desafios da gestão passam necessariamente pelo desafio da Criação de Valor em plena harmonia com os ci dadãos e o meio ambiente. Torna-se necessário especificar que a criação de valor transcende os objetivos básicos clássicos: nas empresas, gerando excedentes e solidez financeira; na esfera pública, externalidades positivas; na sociedade civil, demandas coletivas. Em todos estes casos, a sustentabilidade das estruturas organizacionais é hoje um pilar incontornável, ou seja, a preocupação e a incidência no bem comum, projetadas em um horizonte global e em longo prazo.

Qualquer organização que não considere a equipe humana é uma simples concorrente e coincide com os vários ativos inertes, que não podem ser mobilizados, produzidos ou criados sem a intervenção do gênio e do talento humanos.

Essas reflexões nos remetem a um ponto central no debate contemporâneo, na cosmovisão organizacional e na inegável relevância da ação humana na dinâmica social. Esse genuíno "patrimônio humano" é colocado em simetria com o patrimônio econômicofinanceiro da entidade, ou seja, o valor criado é função de ambos os conglomerados e seus beneficiários são a empresa, como grupo humano, os clientes ou usuários, os fornecedores, a comunidade e o meio ambiente.

A “criação de valor" pode ser entendida com uma compreensão intelectual cristalina, no entanto, a criação de valor no mundo real requer energia, esforço e habilidades complexas. Caso contrário não haveria empresas fechadas, projetos frustrados, sociedades instáveis ou Estados falidos. 
Atualmente, várias expressões e nomes são usados para se referir a "pessoas" do ponto de vista da organização: gestão de recursos humanos, gestão de pessoas, gestão de talentos, administração de recursos humanos, ou gestão de pessoal. Para os nossos propósitos e compreensão do contexto, utilizaremos a expressão "gestão de pessoas" ao longo do texto, lembrando que não é nossa intenção o aprofundamento na etimologia, abrangência, diferenças e alcance dos termos acima mencionados.

Consequentemente, a nossa preocupação se concentrará na gestão de pessoas, no nível da criação de valor organizacional e no contexto da harmonia entre os objetivos organizacionais, avaliação de desempenho e recompensa. Para tanto, a palavra estratégica terá dois âmbitos fundamentais: o primeiro, referindo-se a propósitos de longo prazo e, o segundo, aos fatores e circunstâncias que podem criar ou destruir o patrimônio organizacional. Por outro lado, o foco está orientado para a concepção de uma noção métrica para avaliar o desempenho e, por conseguinte, a recompensa associada aos diferentes níveis de avaliação do desempenho medido.

Por que atribuímos tal relevância à relação desempenho-criação de valor? A resposta emana quase que espontaneamente das ideias apresentadas nos parágrafos anteriores. A construção humana, como fenômeno geral, responde à ordenação voltada para o bem comum sustentável. Assim, o valor organizacional criado, expresso em termos agregados, é o valor social criado, devendo este promover o desenvolvimento humano da sociedade como o maior conglomerado ou grupo de indivíduos.

Portanto, a gestão de pessoas na organização é um dos blocos de construção que contribuem para o bem-estar geral da humanidade. Conclui-se, então, que a gestão da organização individual faz parte da sociedade, ou seja, quando a gestão individual da empresa é bem-sucedida, ela agrega valor à construção da sociedade como um todo. Parafraseando Rousseau, este tipo de Contrato Social em que a organização opera, não é concebido apenas para beneficiar os stakeholders mais evidentes, mas é um verdadeiro agente de mudanças, com dinâmica própria e que busca uma perfeita sincronização com seu ambiente.

Por outro lado, o desempenho superior de quem ocupa um cargo, cujo conteúdo, objetivos e funções estejam alinhados às estratégias da empresa, cria valor para ela. Uma relação adequada entre remuneração e desempenho gera cenários favoráveis para atingir superávits empresariais e, adicionalmente, é fator decisivo para o estabelecimento de um clima organizacional de excelente nível. 
Este trabalho é a primeira fase de uma linha de pesquisa que busca propor um Modelo Estruturador de Estratégia Corporativa e Capital Humano, abordando alinhamento e remuneração variável.

\section{Alinhando a estratégia e o conteúdo de cargos}

$\mathrm{Na}$ formulação das estratégias organizacionais, um dos aspectos centrais é a formulação de objetivos e $\operatorname{metas}^{3}$, intimamente relacionados à afirmação da Visão institucional. Da mesma forma, o papel e o bom exercício da atividade empresarial estão condensados na definição da sua Missão.

Tal fato desencadeia a revisão e reformulação do quadro organizacional da entidade, uma vez que a verticalidade (hierarquia, autoridade e dependência) e a horizontalidade (divisão do trabalho) devem ser concebidas de forma que o organograma também esteja alinhado com a estratégia corporativa.

Essa concepção é observada na figura $\mathrm{n}^{0} 1$, que mostra a sequência a seguir, desde as definições estratégicas até a avaliação de desempenho e remuneração.

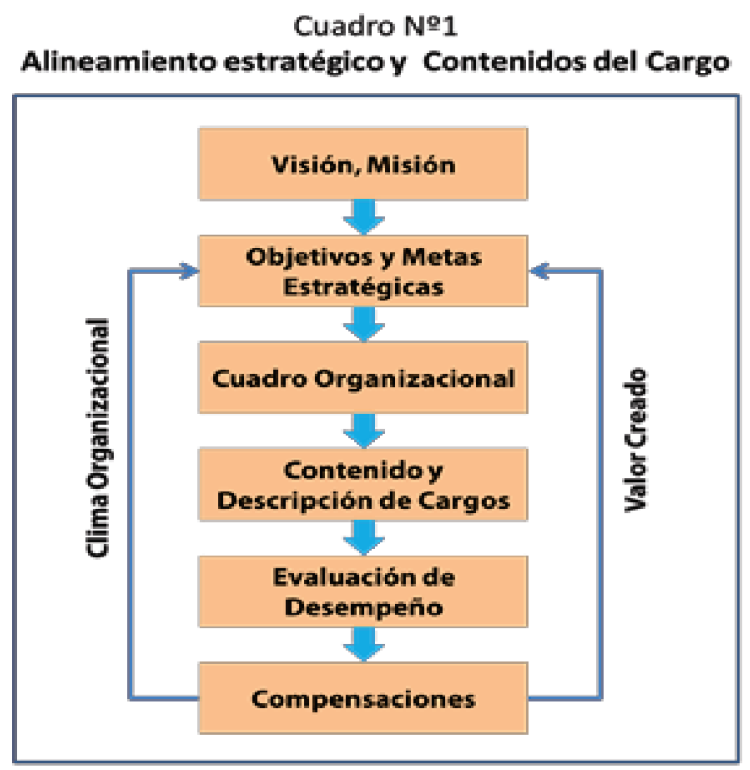

Fuente: Elaboración Propia.

O alinhamento da estratégia ao capital humano implica colinearidade de propósitos, ou seja, se a empresa declara sua Visão e Missão, também é oportuno declarar visões e missões nas unidades de departamentalização. Assim, é possível fazer com que cada unidade trabalhe com sua bússola em função do curso de navegação institucional. Vejamos o seguinte

\footnotetext{
3 Para os fins deste trabalho, entenderemos as metas como "objetivos quantificados". Exatidão da maior relevância, já que quantificar é uma etapa necessária para estabelecer métricas formais.
} 
exemplo: o Conselho Nacional de Bombeiros (JNCB) redefiniu sua Visão (BRAVO Y MIRANDA, 2009a) como "Ser reconhecido pelo Corpo de Bombeiros do Chile como organismo prestador de serviços de alta qualidade na alocação de recursos, suporte técnico e treinamento abrangente para bombeiros. Da mesma forma, aspira ser a referência para a atividade dos Bombeiros do Chile perante o Estado e a comunidade nacional e internacional ". Conforme o sentido de Visão para as suas unidades departamentais (Organograma), a Direção Executiva o define como: "Transformar o JNCB numa organização que, com forte vocação para o serviço, gere os recursos que opera com a maior probidade e eficiência para o cumprimento dos objetivos institucionais." Para a Subdireção de Finanças a Visão é: "Ser reconhecida pela sua solidez técnica, probidade, transparência, empenho no controle e na utilização dos recursos em estreita correlação com as políticas superiores do JNCB.”

Como se pode verificar, os enunciados estratégicos da organização, consagrados na Visão e Missão, foram desdobrados em enunciados análogos e subordinados aos institucionais, nas unidades departamentalizadas que atuam em cada área do JNCB . Da mesma forma, a instituição definiu (BRAVO Y MIRANDA, 2009b) seus objetivos, metas, estratégias, programas, responsáveis, prazos e medidas de avaliação (KPI) conforme suas declarações, assim como cada unidade organizacional está em condições de definir seus próprios parâmetros análogos, ou seja, no caso, cada unidade de responsabilidade adota seu curso de navegação específico alinhado ao curso institucional.

No que se refere ao conteúdo das taxas, tomemos o exemplo da Subdireção de Finanças no caso em questão. O primeiro fator declarado é a "solidez técnica", consequentemente, aspectos como o domínio das finanças de longo e curto prazo, análise financeira, gestão de tesouraria, legislação aplicável como o mercado de valores mobiliários e mão de obra serão elementos fundamentais de quem exerce tal função. O segundo fator é a "probidade", que dá ênfase a alguns requisitos de ingresso, mas, acima de tudo, a uma sólida ética profissional durante o exercício do cargo. O terceiro fator é a "transparência", que foca na existência contínua e permanente de prestação de contas ao público externo e interno, o que requer a manutenção de relatórios e registros atualizados de acordo com a regulamentação em vigor e as práticas profissionais. O quarto fator é o "compromisso com o controle", referindo -se ao amplo escopo da expressão, como verificações e testes permanentes, análise de desvios e lacunas, medidas corretivas e sua exposição adequada e tempestiva. O quinto fator "uso de recursos em estreita correlação com políticas superiores" responde pela sub-rogação aos enunciados institucionais e define, então, as margens de autonomia e dependência do cargo e 
está diretamente relacionado ao que é declarado pelo JNCB na Visão como "corpo de serviço de alta qualidade na alocação de recursos".

O caso ilustra como o alinhamento entre estratégia e conteúdo dos cargos é desenhado e materializado, expressando com clareza a metodologia a ser seguida por executivos, gestores e consultores nas organizações.

\section{Avaliação de desempenho}

Aqui há um inventário de métodos, conhecidos principalmente por diretores e gerentes de recursos humanos. Dessler, G. e Varela, R. (2011) mencionam: Método de Escala de Pontuação Gráfica, Método de Classificação Alternativa, Método de Comparação de Pares, Método de Distribuição Forçada, Método de Incidente Crítico, Escalas de Classificação Baseadas em Comportamento. Chiavenato, I. (2011) também considera alguns como o Método de Pesquisa de Campo e o Método de Frases Descritivas. Essas e outras contêm, em maior ou menor grau, um elemento que dificulta sua aceitação por muitos gestores: a presença constante da subjetividade e a dificuldade de sua limitação. Este último aspecto abre um cenário de análise e pesquisa, após a busca de novas propostas destinadas a medir o grau de cumprimento das principais atividades de um cargo, fato de grande importância à luz dos antecedentes anteriores, uma vez que constituem o insumo medir, de cima para baixo, o grau de cumprimento dos objetivos estratégicos da empresa.

Tarefa difícil é avaliar o desempenho com referência à quantificação de fenômenos qualitativos, ou seja, como é possível mensurar atos relacionados ao comportamento, principalmente no ambiente de trabalho? Diante disso, somos obrigados a recorrer ao suporte de ferramentas matemáticas e estatísticas para articular algum tipo de base sobre a qual construir uma proposição.

\section{Descrição da posição e funções operacionais nucleares}

Há varias maneiras de exprimir o que se designa por Descritor de Funções. Existem formatos básicos e complexos, transversais e específicos. Há também aqueles expressamente desenvolvidos pela organização, tendo em conta a sua realidade e as circunstâncias. Mas, em todas elas, merece uma seção singular quanto às principais atividades do cargo, que doravante chamaremos de "Funções Operacionais Nucleares (FON)". Para efeito da proposição, esta nomenclatura tem um significado preciso, fato que permite compreender suas características e 
abrangência. Uma tarefa árdua é avaliar o desempenho tomando como referência a quantificação dos fenômenos qualitativos.

Ilustraremos a razão central ou fundamental de ser de um cargo, na ordem organizacional, com a expressão Cargo Central. Com isso, tentamos identificar a essência da posição, sua espinha dorsal na empresa. Para satisfazer esta noção é imprescindível, conforme indicado, estabelecer, como no caso apresentado (JNCB), qual a natureza do cargo, desagregando a Visão da unidade departamental.

Feito isso, ou seja, identificada a Posição Central, o próximo passo é a enunciação das Funções Operacionais Nucleares (FON). Estas devem atender a determinados requisitos formais para serem construídos, os quais são observados na figura $\mathrm{n}^{\circ} 2$.

Cuadro №2

Funciones Operacionales Nucleares (FON)

Requisitos para su formulación

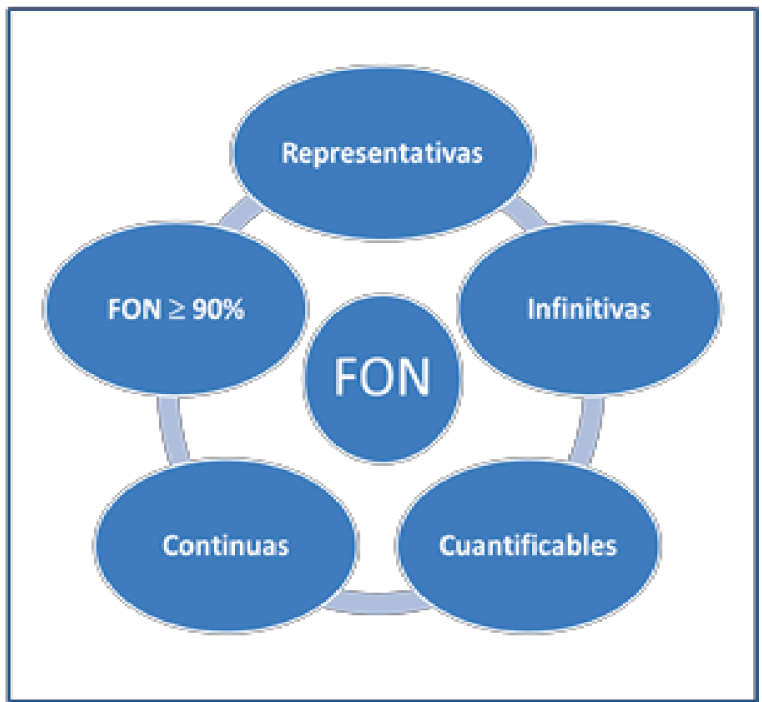

Fuente: Elaboración Propia.

O primeiro requisito a satisfazer é que um FON deve ser totalmente representativo da posição central do cargo, o que implica uma identificação total com o seu papel como contribuinte de valor para a organização. O segundo requisito exige que sua formulação (escrita) seja no infinitivo, o que obriga a representar um FON como verbo, ou seja, indica uma ação, concreta e diferenciável de outra, com total clareza. No terceiro requisito, todo FON deve ser quantificável e passível de ser representado em uma escala padronizada e de entendimento geral. Uma escala centesimal ( $0 \%-100 \%)$ funciona perfeitamente, pois permite comparar, pesar e misturar. No quarto requisito, sua propriedade "quantificável" (terceiro requisito), deve permitir que um FON seja representado como uma função matemática contínua. No quinto requisito, como veremos, os testes realizados nos informam que os FON de um cargo não ultrapassam cinco (5) e que desde o prisma da organização acumulam pelo 
menos 90\% da Posição Central do cargo, devidamente ponderado e apresentado no descritor de trabalho em estrita ordem de prioridade $\left(\mathrm{FON}_{1}>\mathrm{FON}_{2}>\mathrm{FON}_{3}>\mathrm{FON} 4>\mathrm{FON}_{5}\right)$. Assim, se houver outras funções da posição (Funções Operacionais Orbitais, FO2), estas devem acumular os $10 \%$ restantes. Do ponto de vista gerencial, o monitoramento até o nono $\left(9^{\circ}\right)$ representa uma ferramenta de gestão robusta, ou seja, o acúmulo do FON será:

$\sum \mathrm{FON}_{\mathrm{j}} \geq 90 \%$ onde $1 \leq \mathrm{j} \leq 5$

Cada FON será avaliado com sua própria "variável de avaliação" ou variável independente (vj), que alcançará valores característicos do FON como resultado das ações ou transações do ocupante do cargo, e será avaliado como uma variável dependente em uma escala centesimal $(0 \%-100 \%)$ como uma medida de conformidade ou "desempenho" (EDI) para o FON em particular, ou seja:

$$
\mathrm{EDI}_{\mathrm{FONj}}=\mathrm{f}\left(\mathrm{v}_{\mathrm{j}}\right)
$$

Em que "f" representa a expressão funcional e EDI a "avaliação de desempenho" para o FONj. Ao combinar o FON obtemos a "avaliação conjunta de desempenho" (EDC). Esta é a qualidade global no cumprimento do cargo:

$$
\mathrm{EDC}=\Sigma \mathrm{EDI}_{\mathrm{FONj}} \mathrm{x} \mathrm{p}_{\mathrm{j}} \text { con } 1 \leq \mathrm{j} \leq 5
$$

\section{Política de avaliação de desempenho}

Aqui a proposta introduz o conceito de "Política de Avaliação de Desempenho" (PAD), que representa o consenso da Administração quanto à forma de medir o grau de cumprimento dos diferentes cargos e seus respectivos FON. Este conceito constitui uma resposta à aspiração diretiva de eliminar ou reduzir a subjetividade na avaliação de desempenho, que se limita até a definição e formulação organizacional da PAD. Desta forma, as "fontes" de subjetividade da proposição claramente identificadas são:

1. A definição da FON da posição;

2. A ponderação (pj) atribuída a cada FON; Y

3. A definição funcional da PAD.

Uma vez que a empresa tenha definido integralmente a sua política, a partir daí, os resultados da avaliação de desempenho só podem adotar apenas um resultado em determinados níveis de cumprimento da FON de cada cargo, podendo ser convertidos em "aplicações regulares" nos sistemas de informação, gerando indicadores e relatórios de amplo espectro, ou seja, os resultados obtidos são homogeneamente comparáveis e funcionam como 
um índice de evolução, característica de grande relevância, pois permite dar feedback, realizar rodízios de cargos, promoções, necessidades de treinamento e decidir pela rescisão de vínculo.

\section{Representação funcional}

A expressão concreta de uma PAD se reflete em uma expressão gráfica e em um conjunto de funções e equações.

Para ilustrar esta última fase, vamos examinar o seguinte caso: uma empresa deseja avaliar o desempenho de seu Gerente Financeiro Adjunto. O cargo, segundo a empresa, contribui para o alinhamento com as seguintes atividades, que definiu como a FON do cargo, situação que pode ser observada na figura $\mathrm{n}^{\circ} 3$.

\section{Cuadro №3}

Subgerente de Finanzas

Definición de la empresa de sus FON $\Sigma F O N j \geq 90 \%$

\begin{tabular}{|c|c|c|}
\hline FON & DESCRIPCIÓN & PONDERACIÓN \\
\hline $\mathrm{FON}_{1}$ & $\begin{array}{l}\text { Mantener ciclo de caja en la } \\
\text { condición (Periodo medio de } \\
\text { cuentas por cobrar) } \leq \text { (Periodo } \\
\text { medio de cuentas por pagar) }\end{array}$ & $30 \%$ \\
\hline $\mathrm{FON}_{2}$ & $\begin{array}{l}\text { Contratar deuda de corto plazo } \\
\text { del sistema financiero con tasas } \\
\text { (t) que cumplan t s t media de } \\
\text { mercado para operaciones } \\
\text { similares de los seis (6) últimos } \\
\text { meses }\end{array}$ & $25 \%$ \\
\hline $\mathrm{FON}_{3}$ & $\begin{array}{l}\text { Pagar a los Proveedores Clave } \\
\text { (definidos por la empresa) con } \\
\text { un máximo de } 15 \text { dias de } \\
\text { retardo respecto de la fecha } \\
\text { nominal de facturas }\end{array}$ & $20 \%$ \\
\hline $\mathrm{FON}_{4}$ & D4... & $15 \%$ \\
\hline \multirow[t]{2}{*}{$\mathrm{FON}_{5}$} & D5... & $10 \%$ \\
\hline & TOTAL $=$ & $100 \%$ \\
\hline
\end{tabular}

Fuente: Elaboración Propia.

Para ilustrar esta tarefa, vamos pegar a FON1 do caso e ver como a empresa a definiu, avaliando o desempenho do ocupante do cargo. Esta função leva em conta a correspondência (ou incompatibilidade) da tesouraria. Suponhamos que para a empresa é relevante ter uma correspondência ou dias a favor desde que seja maior ou igual a 40 dias. Neste negócio, ao nível da indústria, é extremamente difícil obter correspondências acima de 60 dias. Os 
gestores reúnem-se e após acalorado debate chegam a um acordo, que é comunicado à Comissão Executiva do Conselho, com poderes para aprovar ou rejeitar. Por fim, sai a fu maça branca e é aprovada a proposta de avaliação de desempenho da FON1 (esta que propomos constitui uma simplificação da realidade, já que a PAD é apresentada para todos os cargos da empresa, se necessário). A medida aprovada, em forma gráfica, é expressa da seguinte forma, conforme figura $\mathrm{n}^{\circ} 4$ :

\section{Cuadro №4}

POLÍIICA DE EVALUACIÓN DE DESEMPEÑO DE LA EMPRESA

SUBGERENCIA DE FINANZAS - SITUACIÓN DE CAJA - FON ${ }_{1}$

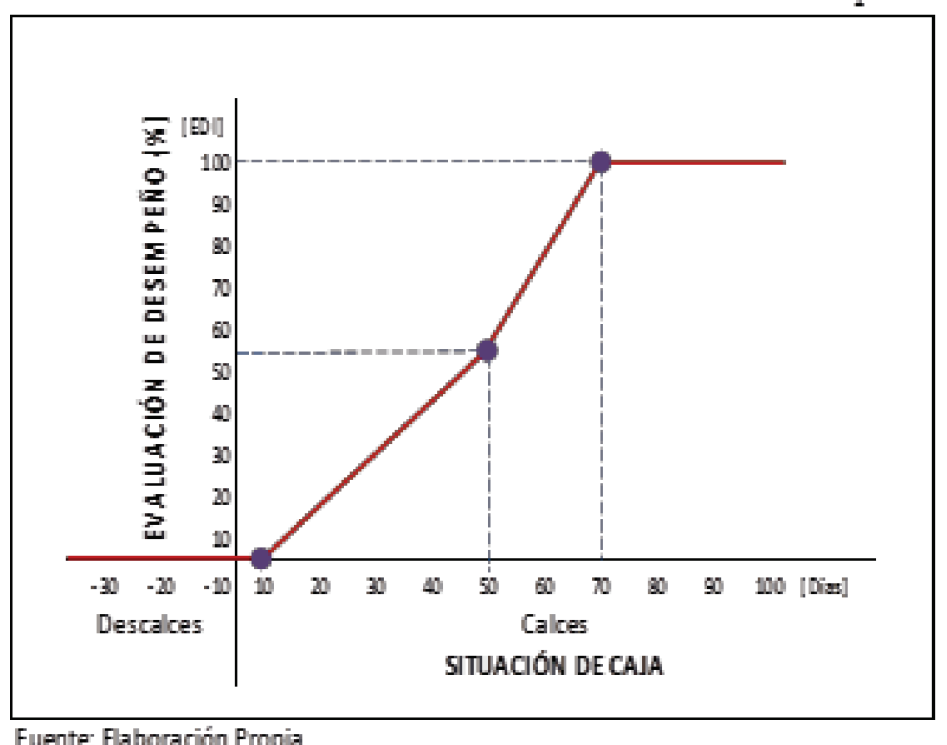

Uma primeira observação, para a construção da política, é que se propõe trabalhar com segmentos lineares por duas razões: a primeira, evita a formulação de polinômios; a segunda, as funções lineares são rápidas de calcular e fáceis de programar.

O número de funções dependerá dos intervalos que definem a política e a avaliação (eixo de ordenadas) que se deseja atribuir aos diferentes níveis de cumprimento da variável de avaliação (eixo de abcissas).

$\mathrm{Na}$ forma analítica, a política é expressa:
$\mathrm{EDI}=0$
Se $\quad \mathrm{D} \leq 10$
$\mathrm{EDI}=(55 / 40) \times \mathrm{D}-(55 / 4)$
Se $\quad 10<\mathrm{D} \leq 50$
$\mathrm{EDI}=(45 / 20) \times \mathrm{D}-(115 / 2)$
Se $\quad 50<\mathrm{D} \leq 70$
$\mathrm{EDI}=100$
Se $\quad \mathrm{D}>70$ 
Observe que a inclinação da função linear correspondente ao intervalo [50; 70] é maior que a inclinação da função do intervalo $[10 ; 50]$, de forma que um aumento da variável de avaliação neste último intervalo seja maior do que se ocorrer naquele. Em outras palavras, o crescimento da unidade é recompensado com taxas mais altas de $\mathrm{D}=50$, o que constitui um incentivo claro para o ocupante da posição.

\section{CONCLUSÕES}

A Avaliação de Desempenho e os Descritores de Cargos por meio da Metodologia EDAE Corporate $($ C representam um claro avanço no sentido de reduzir e controlar a subjetividade na mensuração dos resultados dos ocupantes de cargos em uma organização.

Como se pode verificar, ao longo da proposição, o EDAE Corporate $C$ é uma ferramenta a serviço dos objetivos estratégicos da empresa, sempre que a metodologia seja integralmente aplicada. Implementações parciais podem complicar ainda mais a situação organizacional em termos de gestão de pessoas.

O EDAE Corporate (C) também é a porta de entrada para a atribuição e determinação de remuneração variável com fortes níveis de correlação com as expectativas (resultados) da empresa quanto à gestão de cada um dos cargos.

O fato de limitar os graus de subjetividade na avaliação de desempenho, até que a política seja efetivada, representa um avanço significativo, uma vez que a partir do momento de sua aplicação os resultados independem de quem faz a avaliação.

A Metodologia EDAE Corporate (C) é aplicável a todos os tipos de cargos, geradores ou não de receitas, de natureza quantitativa implícita ou não. A ferramenta sempre oferece a oportunidade de quantificar aspectos qualitativos.

Da mesma forma, é aplicável em diversos setores da atividade econômica, da mesma forma que pode ser utilizado por entidades públicas e organizações sem fins lucrativos.

Mesmo com esses insights, a EDAE Corporate (C) é uma proposta que resolve apenas uma fração do problema da gestão de pessoas. Ainda há muito a ser feito neste campo. Quanto mais sofisticadas forem nossas atividades, teremos que enfrentar novos desafios em termos de recursos humanos.

\section{REFERÊNCIAS}

BRAVO, P.; MIRANDA, J. JNCB, Plan Estratégico Institucional, Estructura General. B\&M Servicios Corporativos, Documento de Trabajo. Santiago. 2009a. 
BRAVO, P.; MIRANDA, J. JNCB, Implementación de Planificación Estratégica Institucional, Fase II, Diagnóstico Organizacional. B\&M Servicios Corporativos, Documento de Trabajo. Santiago. 2009b.

CHIAVENATO, I. Administración de Recursos Humanos. El capital humano en las organizaciones. McGraw-Hill. 9ª Edición. México. 2011.

DAVID, F. Conceptos de Administración Estratégica. Pearson Educación. 11 ${ }^{\text {a }}$ Edición. México. 2008.

DE LA CORTE, J.; MIRANDA, J. Declaración de Panamá Sobre Responsabilidad Social, Oportunidades y Desafíos. De La Corte \& Miranda. Santiago-Sevilla. 2012.

DESSLER, G.; VARELA, R. Administración de Recursos Humanos. Pearson Educación. 5a Edición. México. 2011.

FRANCÉS, A. Estrategia y Planes Para la Empresa Con el Cuadro de Mando Integral. Pearson Educación. 1 ${ }^{a}$ Edición. México. 2006.

GARCÍA, L.; GARCÍA, J. Impacto de la Inversión en Capital Humano Sobre el Valor Empresarial. Revista Latinoamericana de Administración. No 51, pp. 15-26. 2012.

HODGE, B. J. et al. Teoría de la Organización. Un Enfoque Estratégico. Pearson Educación.

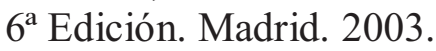

MIRANDA, J. Gestión de Personas. Herramientas Cuantitativas Aplicadas a Compensaciones. Revista Científica "Teoría, Enfoques y Aplicaciones en las Ciencias Sociales", No 5, pp. 107-116. 2010.

MONDY, R. Administración de Recursos Humanos. Pearson Educación. 11 ${ }^{\mathrm{a}}$ Edición. México. 2010.

STREBEL, P. et al. Gestión del Cambio. ¿Por Qué los Empleados se Resisten al Cambio? Deusto. $1^{\text {a }}$ Edición. Buenos Aires. 2004.

VALLE, R. La Gestión Estratégica de los Recursos Humanos. Pearson Educación. 2a Edición. Madrid. 2004.

WHEELEN, T.; HUNGER, J. Administración Estratégica y Política de Negocios. Conceptos y Casos. Pearson Prentice Hall. 10 Edición. México. 2007. 


\title{
FEMINICÍDIO: CRIME HEDIONDO CONTRA A MULHER
}

\author{
https://dx.doi.org/10.48097/2674-8673.2021n5p11
}

\author{
Soraya Manoela Alves da Silva ${ }^{1}$ \\ Carlos Cavalcanti ${ }^{2}$
}

\section{RESUMO}

Este artigo traz um estudo sobre a questão da violência contra a mulher, com destaque para a discussão do feminicídio, suas causas e consequências. Através da reconstrução de nossas raízes históricas e culturais, é mostrado que a violência contra a mulher é um fato não apenas corriqueiro, mas aceito e justificado por toda uma ideologia machista e sexista de dominação. A lei do feminicídio, assim como a lei Maria da Penha, aparecem como respostas dadas pelos movimentos em defesa da mulher para este grave problema. A definição de crime hediondo e homicídio qualificado para o assassinato de mulheres representa um marco em nossa legislação penal, fruto do reconhecimento de que as questões de gênero são importantes e devem ser debatidas por todos.

Palavras-chave: Feminicídio. Lei Maria da Penha. Código Penal. Gênero.

Data de submissão: 25/02/2021

Data de aprovação: $24 / 03 / 2021$

\begin{abstract}
This article brings a study on the issue of violence against women, with emphasis on the discussion of feminicide, its causes and consequences. Through the reconstruction of our historical and cultural roots, it is shown that violence against women is not only a common fact, but accepted and justified by a sexist ideology of domination. The feminicide law, as well as the Maria da Penha law, appear as responses given by the movements in defense of women to this serious problem. The definition of heinous crime and qualified homicide for the murder of women represents a milestone in our penal legislation, the result of the recognition that gender issues are important and must be debated by everyone.
\end{abstract}

Keywords: Feminicide. Maria da Penha Law. Penal Code. Gender.

\section{INTRODUÇÃO}

A sociedade brasileira ainda é muito machista e preconceituosa, principalmente quando se trata de defender os direitos das mulheres e protegê-las do assédio e da violência

\footnotetext{
${ }^{1}$ Discente do Curso de Bacharelado em Direito da Faculdade Metropolitana da Grande Recife. E-mail: melindaluisa@outlook.com

2 Orientador / Docente do Curso de Bacharelado em Direito da Faculdade Metropolitana da Grande Recife. E-mail: carloscavalcanti@metropolitana.edu.br
} 
dos homens, dos quais muitos ainda se acham no direito de fazer o que quiserem com suas companheiras, desde a traição até a violência física.

Este cenário vem mudando ao longo dos anos, num movimento em que a mulher vem ganhando cada vez mais consciência do seu papel como protagonista da sociedade, e a própria sociedade vem reconhecendo sua dignidade, ampliando seus direitos, coibindo e punindo todas as formas de violência contra a mulher.

Muitas leis têm surgido para proteger as mulheres da violência, principalmente a doméstica, a mais comum dentre elas. A Constituição foi um passo importante, pois trouxe, ainda que de maneira indireta, a discussão a respeito da valorização da mulher e do combate à violência por ela sofrida.

Além da Constituição, é preciso destacar, de forma ainda mais forte, a importância da Lei 11.340/2006, conhecida como Lei Maria da Penha, que se tornou um marco na luta e no combate à violência doméstica. Esta lei representou um enorme avanço no combate à violência contra a mulher. Juntamente com a lei, foi se formando uma estrutura protetiva que visava garantir ainda mais a proteção da mulher contra seus agressores.

Daí surgiram as delegacias especializadas no enfrentamento à violência doméstica, dando mais segurança às vítimas. Porém, a violência contra a mulher ainda persiste e ainda convive com uma mentalidade arcaica, em que os homens se acham no direito de agredir suas companheiras.

Para fortalecer ainda mais o combate a este tipo de prática, foi instituída a lei 13.104, de 09 de março de 2015, e que ficou conhecida como a lei do feminicídio, a qual veio para aumentar o rigor das penalidades e dar maior gravidade aos crimes cometidos com base no gênero, envolvendo quase sempre o homem e sua companheira. A partir desta lei, o feminicídio passou a ser previsto como circunstância qualificadora de homicídio, além de ser incluído no rol dos crimes hediondos.

A pergunta que norteia este trabalho é a seguinte: ao ser tratado como crime hediondo, o feminicídio contribui para diminuir a violência contra a mulher? O objetivo desta pesquisa é mostrar de que forma a lei do feminicídio contribui para ampliar a discussão a respeito da violência contra a mulher, combatendo as várias formas pelas quais esta se manifesta.

O debate a respeito da condição da mulher em nossa sociedade vem crescendo cada vez mais. A presente pesquisa é de caráter qualitativo, baseada no estudo da doutrina jurídica, no estudo a respeito da violência contra a mulher e na análise das leis e da jurisprudência.

Para melhor aprofundar o tema, o artigo foi dividido em três partes. Na primeira, é apresentada uma discussão a respeito da violência de gênero, sobretudo no que diz respeito à 
mulher. Na segunda parte, introduzimos a legislação a respeito da mulher, com destaque para a Lei Maria da Penha. E na parte final é apresentada a lei do feminicídio, seus aspectos principais, bem como os avanços que ela se propôs a fazer no combate à violência contra a mulher.

\title{
A VIOLÊNCIA DE GÊNERO
}

É necessário deixar claro que se trata de um ato de violência praticado, sobretudo, por aqueles que se consideram superiores às mulheres e que veem sua condição de mando e superioridade serem ameaçados pela ascensão delas, uma vez que as mesmas estão cada vez mais ocupando espaços na sociedade que antes eram ocupados pelos homens.

Ao definir a violência Saffioti (2004, p. 17) diz que ela é uma "ruptura de qualquer forma de integridade da vítima: integridade física, integridade psíquica, integridade sexual, integridade moral". Podemos notar que a referida autora traz um conceito amplo de violência, não se limitando apenas ao elemento físico, ao corpo, mas abarcando todos os outros aspectos que compõem o ser humano e que, por isso mesmo, entram na lista de fatores desencadeadores da violência.

Em seu artigo sobre a violência contra a mulher, Lays Conceição Franco (2014) diz que "ao abordar a violência contra a mulher, vincula-se o termo violência de gênero, enquanto sinônimo e expressão no sentido de produzir efeitos, ao que tange a violência contra mulheres perpetrada por homens, na condição de dominador/explorador”.

Neste sentido, a autora afirma que

\begin{abstract}
os avanços que as mulheres conquistaram, em termos sociais e culturais, nas mais diversas categorias histórico-políticas, configurados em maior nível educacional, possibilidades profissionais, consequentemente, certa autonomia econômica, trouxe consigo maior inconformismo, visto que os homens passaram a viver em um espaço de disputa, deixando, mesmo que gradualmente, de serem sempre vistos como sexo superior, cujas atitudes eram inquestionáveis e deveriam ser respeitadas. (LAYS, 2014, p. 54).
\end{abstract}

É inegável que as mulheres alcançaram outro patamar em nossa sociedade. Elas passaram muito tempo vivendo à sombra dos homens, como apêndice do lar, atuando apenas como dona de casa, esposa, mãe e cuidadora dos filhos, sem perspectivas que não a de acompanhar e ajudar no crescimento material e profissional do homem, o que sempre a prejudicou, colocando-a numa situação de inferioridade e, mais ainda, de exploração de sua condição feminina. 


\title{
Sociedade e Machismo
}

O feminicídio se insere dentro de um contexto representado por uma sociedade patriarcal, patrimonialista e machista. Considerar estes elementos nos ajuda a entender melhor os aspectos conceituais do feminicídio, bem como sua caracterização na literatura e legislação jurídica.

Em relação à nossa formação histórica, marcada por um processo de colonização europeu que se utilizou largamente da mão de obra escrava indígena e negra, bem como por um regime econômico de monocultura da cana e centrado na família do patriarca, os traços de autoritarismo por parte do homem são muito fortes.

Os casamentos por contrato, advindos de interesses econômicos eram muito comuns no início de nossa formação. Através do oferecimento de um dote, o pai presenteava sua filha com o varão abastado que comprava seu amor, afeição, cuidado, afeto. Por ser protetor, o homem devia cumprir o seu dever de corrigir sua esposa, aplicando inclusive castigos físicos.

Afinal de contas, a mulher lhe pertence, é um sujeito frágil, frívolo. O homem é a própria representação da força, coragem, decisão. Ele é o desbravador; a mulher, a terra a ser desbravada. É justamente destas construções que podemos retirar a figura do masculino como o sujeito da sexualidade. Em seu trabalho sobre a relação entre machismo e violência, Maria Cecília de Souza Minayo diz que:

\begin{abstract}
A concepção do masculino como sujeito da sexualidade e o feminino como seu objeto é um valor de longa duração da cultura ocidental. Na visão arraigada no patriarcalismo, o masculino é ritualizado como o lugar da ação, da decisão, da chefia, da rede de relações familiares e da paternidade como sinônimo de provimento material: é o "impensado" e o "naturalizado" dos valores tradicionais de gênero. Da mesma forma e em consequência, o masculino é investido significativamente com a posição social (naturalizada) de agente do poder da violência, havendo, historicamente, uma relação direta entre as concepções vigentes de masculinidade e o exercício do domínio de pessoas, das guerras e das conquistas. $\mathrm{O}$ vocabulário militarista erudito e popular está recheado de expressões machistas, não havendo como separar um de outro. (MINAYO, 2005, p. 77).
\end{abstract}

Segundo a autora, há uma relação direta entre masculinidade e violência. O másculo é aquele sujeito capaz de demonstrar sua força sempre que necessário. Aliás, este é o fundamento de sua existência, sua razão de ser. Ao homem é negada toda e qualquer demonstração de fraqueza, dor, medo. Isso pertence à condição feminina, marcada pela fragilidade, doçura e aceitação do domínio masculino. Isto se expressa também no mundo da criminalidade e dos atos violentos, como nos diz Minayo:

No mundo da criminalidade, a ideia fundante de macho violento se centra na mesma crença arraigada do masculino como o espaço da iniciativa, do poder e da imposição da vontade, fazendo a associação de dois planos, o da sexualidade e o da sociabilidade. A moral do macho violento é a da virilidade que se apodera do corpo, dos desejos, dos projetos, dos negócios e da vida do outro. (MINAYO, 2005, p.78). 
Quando traçamos um paralelo destes comportamentos em relação à forma como o homem percebe sua relação com a mulher, observamos então estes mesmos traços e atitudes, que denotam uma percepção de si mesmo como sujeito de direito sobre o corpo e a vida da mulher. Neste sentido, a violência e a sua autojustificação se complementam. Se a mulher foi morta ou agredida, certamente o mereceu, pois desrespeitou o elemento masculino, não se submeteu ao seu mando e controle. E isto serve, perigosamente, de pretexto para que o homem se veja no direito de atentar contra a integridade física de sua companheira, vizinha, estranha, etc. Em todas estas situações podemos perceber a presença do feminicídio.

\section{Feminicídio: aspectos conceituais}

Para caracterizar o feminicídio é necessário fazer a sua relação com a violência de gênero, pois ele é a sua expressão mais visível. Não vamos nos deter aqui no conceito jurídico, pois faremos isto no próximo tópico, quando analisarmos as definições trazidas pelo ordenamento jurídico específico sobre tal questão. O que importa neste momento é compreender suas razões e qualificações sociais a fim de que se torne mais claro para nós as razões pelas quais nossa legislação enfrentou este problema.

O interessante estudo sobre o feminicídio e sua invisibilidade, organizado pelas pesquisadoras Débora Prado e Marisa Sanematsu, e patrocinado pelo Instituto Patrícia Galvão, trata este tema à luz das questões culturais e sociais ligadas ao gênero. Daí se afirma que:

Para entender o que é o feminicídio é necessário compreender o que é a violência de gênero, já que o crime de feminicídio é a expressão extrema, final e fatal das diversas violências que atingem as mulheres em sociedades marcadas pela desigualdade de poder entre os gêneros masculino e feminino e por construções históricas, culturais, econômicas, políticas e sociais discriminatórias. (PRADO; SANEMATSU, 2017, p.16).

Portanto, o feminicídio está relacionado à violência sofrida pelas mulheres simplesmente por causa da condição de pertencerem ao gênero feminino. Isto ocorre por causa de construções históricas que colocam a mulher numa situação dada, mostrando que seu lugar na sociedade já está definido e que a não aceitação desta condição implica uma rebelião contra tudo o que já foi estabelecido pela própria sociedade. $\mathrm{Na}$ verdade, boa parte da educação das filhas durante muito tempo esteve voltado para o aprendizado dos afazeres domésticos e para a preparação da mesma para as tarefas que deveriam ser executadas no matrimônio. Para muitas famílias, o mais importante era dar a suas filhas um bom casamento, arranjar um bom esposo, ou seja, um homem capaz de sustentá-la financeiramente, 
proporcionando o conforto e a segurança que ela encontrava no aconchego do lar, sobre a presidência e autoridade do pai.

Saffioti (2004) vai relacionar a questão do gênero dentro da discussão sobre o patriarcado, pois para ela não dá para descolar uma coisa da outra, pois o gênero não é um conceito neutro, mas uma categoria que pode ser visualizada e compreendida historicamente a partir de relações determinadas de poder que estão presentes em todas as relações sociais.

Partindo destas distinções, Saffioti (2004, p. 136) diz que "tratar esta realidade exclusivamente em termos de gênero distrai a atenção do poder do patriarca, em especial como homem/marido, 'neutralizando' a exploração-dominação masculina”. É justamente por não ser um conceito neutro que o gênero, nas palavras de Saffioti (2004, p. 136) "carrega uma dose apreciável de ideologia”, ou seja, ele está muitas vezes marcado por esta expressão do patriarcado que tenta neutralizar o termo, apresentando-o apenas como mera diferença entre os sexos. Diante desta constatação a respeito da relação conceitual entre gênero e patriarcado, Saffioti diz que:

Assim, se gênero é um conceito útil, rico e vasto, sua ambiguidade deveria ser entendida como uma ferramenta para maquiar exatamente aquilo que interessa ao feminismo: o patriarcado, como um fato inegável para o qual não cabem as imensas críticas que surgiram. (SAFFIOTI, 2004, p. 136).

Estamos, pois, diante de uma situação de desigualdade. E não nos referimos ao aspecto físico, ao elemento de fragilidade supostamente presente na condição física da mulher, mas em outros aspectos que tornam as relações entre gêneros desiguais e opressivas para as mulheres. Como dizem Prado e Sanematsu:

\footnotetext{
Essas desigualdades e discriminações manifestam-se de diversas formas, que vão do acesso desigual a oportunidades e direitos até violências mais graves. É esse círculo que alimenta a perpetuação dos casos de assassinatos de mulheres por parentes, parceiros ou ex que, motivados por um sentimento de posse, não aceitam o término do relacionamento ou a autonomia da mulher. Ou ainda as mortes associadas a crimes sexuais e aqueles em que a crueldade revela o ódio ao feminino, entre outros casos. (PRADO; SANEMATSU, 2017, p. 19).
}

Como ressaltado pelas autoras, as oportunidades são desiguais. A própria remuneração das mulheres no mercado de trabalho é inferior aos homens, levando a uma situação de contrastes múltiplos, onde se revela uma violência social. Concomitante a isto temos a violência física e a violência simbólica, que se alimentam mutuamente e que são perpetradas por seus companheiros, que se acham donos de suas parceiras, praticando inclusive crimes de ordem sexual contra as mesmas.

Diante de todo este cenário social, e por causa da resistência das mulheres e de vários grupos na sociedade, a questão do feminicídio passou a ser tipificada em nossa legislação, 
contribuindo desta forma para a punição daqueles que se utilizam de argumentos naturalistas e machistas para agredirem suas companheiras.

\section{A TIPIFICAÇÃO DA VIOLÊNCIA DE GÊNERO NA LEGISLAÇÃO}

Ao longo da história a violência contra a mulher foi, não apenas tolerada, como justificada pela sociedade e tudo isto com base em argumentos filosóficos, religiosos, políticos, sociológicos, etc. Como não poderia deixar de ser, os diversos códigos legislativos corroboraram esta violência, adequando suas normas a esta situação de opressão social por parte de uma sociedade machista contra a mulher.

O caminho foi longo e árduo até se chegar às leis que pudessem amparar e condenar tais atos violentos praticados principalmente pelos companheiros e pessoas próximas das mulheres. As lutas pelo reconhecimento da dignidade da mulher na sociedade se estenderam desde o campo dos direitos políticos, permitindo o voto, a participação nas assembleias, a possibilidade de concorrer a cargos eletivos, dentre outros.

Porém, apesar de todos estes avanços, as práticas violentas continuaram a ser exercidas sobre a mulher, levando as mesmas a lutar incessantemente pelo estabelecimento de leis que garantissem sua proteção contra tais arbitrariedades e a punição daqueles que praticassem atos de violência, baseados numa errônea ideia de superioridade do masculino sobre a condição feminina.

\section{Evolução histórica do crime contra a mulher}

A posição da mulher ao longo da história, no Ocidente, foi a de cumprir um papel subalterno em relação ao homem, tendo suas funções restritas à reprodução e cuidado dos filhos, mantendo-se fiel ao marido durante toda a sua vida. Isto não ocorria de forma uniforme em todos os períodos e civilizações, mas constitui uma regra básica no tratamento e na visão que se tinha do papel da mulher na sociedade.

As ideias referentes à fidelidade, traição, adultério, estavam relacionadas geralmente aos atos praticados pela mulher e que geravam uma reprovação social de grande alcance. Em seu trabalho sobre a violência contra a mulher, Rosilene Almeida Santiago e Maria Thereza Ávila Dantas Coelho (2007) fazem uma breve contextualização histórica da questão da violência contra a mulher. A famosa lei de Talião (olho por olho, dente por dente) era muito rígida em relação às questões morais. Na Mesopotâmia, o casamento era considerado um ato de compra da mulher. Ela não podia rejeitar o marido, sequer falar mal dele publicamente, sob 
pena de ser atirada ao rio, com os pés e mãos amarradas. Outros casos históricos são retratados por Coelho e Santiago:

No Direito Romano, não cabia ao Estado a punição do delito da mulher, ou seja, as infratoras não eram punidas com pena pública, ficando esta tarefa sob a responsabilidade do homem. Durante a Idade Média, a discriminação contra a mulher foi a mais cruel. Para cada dez bruxas queimadas na fogueira da Inquisição, apenas um era bruxo. (COELHO; SANTIAGO, 2007, p. 112).

Podemos perceber que no século XIX, marcado pela consolidação do capitalismo como sistema econômico, ou seja, com a derrubada total do sistema feudal medieval, a mulher ainda era tratada de forma subalterna, sendo que o homem era visto como um ser dotado de grandes capacidades.

Devido a nossa formação histórica estar relacionada ao patriarcalismo, a situação da mulher foi bastante precária em relação à proteção da legislação em casos de agressão por parte do homem. No Período Imperial o adultério passou a ser punido. No caso, a mulher adúltera "cumpria pena de um a três anos, com trabalhos forçados" (Coelho e Santiago, 2007). $\mathrm{O}$ ato adulterino cometido pela esposa era considerado uma afronta à dignidade do homem, algo que prejudicava a sua imagem pública.

No começo do século XX, no Brasil, ainda era muito comum ler notícias nos jornais que falavam de assassinatos de mulheres por seus companheiros, tudo isto movido por questões passionais. Coelho e Santiago (2007) lembram o artigo 27 do código penal de 1890, em que cita que a pena do acusado por crimes passionais "pode ser absolvida ou amenizada, com o argumento de que os sentidos e a inteligência do réu se tornam privados durante o ato criminoso, sob os impulsos da duradoura paixão ou, mesmo, da súbita emoção".

O código penal de 1940, segundo Coelho e Santiago:

Eliminou a licitude relativa à "perturbação dos sentidos e da inteligência", que deixava impunes os assassinos chamados de passionais, adotando a categoria "homicídio privilegiado", pela qual o criminoso, mesmo tendo uma pena menor do que o homicídio simples (6 anos), não fica mais impune. (COELHO; SANTIAGO, 2007, p. 122).

Entretanto, a alegação de homicídio privilegiado continuou sendo largamente usado para justificar a ideia de crime passional, reportando tudo isto à questão da legítima defesa da honra e da dignidade. Foi necessário esperar a Lei Maria da Penha e a lei conta o feminicídio para que esta questão fosse tratada sob a ótica do respeito à dignidade da mulher, de forma a não buscar as mais diversas justificativas para isentar o homem (marido, companheiro) do ato criminoso em relação à mulher. Neste novo cenário, a vítima não mais passa a ser a culpada pelo seu infortúnio, uma vez que nada pode justificar um ato de tal natureza, que tire a vida de outra pessoa. 


\section{A lei Maria da Penha}

Um dos primeiros dispositivos legais a tratar da questão da violência contra a mulher foi a Lei 11.340/06, conhecida como Lei Maria da Penha, um marco da história da proteção legal às mulheres em nosso país. Sabemos que a constituição de 1988 consagrou o princípio da igualdade de todos perante a lei, incluindo nesta lista de itens, a questão da igualdade de gêneros, conforme está escrito no seu artigo $5^{\circ}$, parágrafo $1^{\circ}$, o qual diz que "homens e mulheres são iguais em direitos e obrigações, nos termos desta Constituição". Não resta dúvida sobre o que a carta magna propõe em termos de isonomia no tratamento entre os sexos.

No artigo 226, parágrafo $8^{\circ}$, o texto constitucional diz que “o Estado assegurará a assistência à família na pessoa de cada um dos que a integram, criando mecanismos para coibir a violência no âmbito de suas relações". Porém, houve a necessidade de criar outro dispositivo legal, na forma de lei ordinária, para regulamentar, dar finalidade prática ao dispositivo constitucional. A Lei Maria da Penha (11.340/06), que serve a este propósito, afirma em seu parágrafo primeiro:

Art. $1^{\circ}$ Esta Lei cria mecanismos para coibir e prevenir a violência doméstica e familiar contra a mulher, nos termos do $\S 8^{\circ}$ do art. 226 da Constituição Federal, da Convenção sobre a Eliminação de Todas as Formas de Violência contra a Mulher, da Convenção Interamericana para Prevenir, Punir e Erradicar a Violência contra a Mulher e de outros tratados internacionais ratificados pela República Federativa do Brasil; dispõe sobre a criação dos Juizados de Violência Doméstica e Familiar contra a Mulher; e estabelece medidas de assistência e proteção às mulheres em situação de violência doméstica e familiar.

O principal foco da lei foi prevenir a violência doméstica, pois é sabido que boa parte dos casos de agressão contra a mulher ocorre no ambiente familiar, perpetrada quase sempre pelos seus próprios companheiros. É por isto que a lei enfatiza esta situação específica, pois ela faz parte do cotidiano de muitas mulheres. Ela também estabelece medidas protetivas para que os atos de violência não cheguem a ser consumados, propondo, inclusive, a criação dos juizados e delegacias especiais para a proteção e amparo da mulher vítima da violência doméstica. Os artigos seguintes que compõem o preâmbulo da lei são igualmente importantes, pois ilustram a relação da lei com o que está posto em nossa carta magna:

Art. $2^{\circ}$ Toda mulher, independentemente de classe, raça, etnia, orientação sexual, renda, cultura, nível educacional, idade e religião, goza dos direitos fundamentais inerentes à pessoa humana, sendo-lhe asseguradas as oportunidades e facilidades para viver sem violência, preservar sua saúde física e mental e seu aperfeiçoamento moral, intelectual e social.

Art. $3^{\circ}$ Serão asseguradas às mulheres as condições para o exercício efetivo dos direitos à vida, à segurança, à saúde, à alimentação, à educação, à cultura, à moradia, ao acesso à justiça, ao esporte, ao lazer, ao trabalho, à cidadania, à liberdade, à dignidade, ao respeito e à convivência familiar e comunitária. 
De fato, isto representa um grande salto qualitativo no estabelecimento das condições necessárias para se respeitar a mulher, pois a lei enfatiza o caráter normativo destas obrigações, bem como sua face democrática, pois é preciso saber conviver com as diferenças.

Como bem salientou Saulo Ramos Furquim (2014), estes crimes não eram punidos e contavam muitas vezes com o silêncio da sociedade, apesar do seu caráter nefasto, já que é cometido por alguém que faz parte do círculo íntimo da vítima. Aquele que deveria proteger sua companheira acaba se transformando em algoz e, quando isto acontece, o poder público nada faz para punir o delito à sua altura. A lei Maria da Penha teve o mérito de trazer este tema para o debate social, trazendo a questão da punição aos praticantes desta violência operada no âmbito doméstico.

\section{A lei do feminicídio}

Se a Lei Maria da Penha pode ser considerada um marco na luta contra a violência doméstica, a lei 13.104/15, conhecida como Lei do Feminicídio, representa a grande vitória para os movimentos em defesa da dignidade da mulher, pois confere aos crimes perpetrados contra as mulheres um grau de gravidade muito maior, além de aumentar a severidade da justiça para com os agressores. Em seu preâmbulo ela deixa claro que altera o art. 121 do Decreto-Lei no 2.848, de 7 de dezembro de 1940, para prever o feminicídio como circunstância qualificadora do crime de homicídio, e o art. $1^{\circ}$ da Lei no 8.072, de 25 de julho de 1990, para incluir o feminicídio no rol dos crimes hediondos.

De fato, o código penal, criado através da lei 2.848/40, na parte que trata dos crimes contra a pessoa e contra a vida, estabelece em seu artigo 121 o homicídio simples, cuja pena é a de reclusão de 6 a 20 anos, e o homicídio qualificado, cuja pena envolve a reclusão de 12 a 30 anos.

Na redação original do código, constavam várias circunstâncias que caracterizavam o homicídio qualificado. A lei 13.104/15 incluiu entre os tipos elencados no $\S 2^{\circ}$, o inciso VII, que coloca como homicídio qualificado o feminicídio, ou seja, o crime "contra a mulher por razões da condição de sexo feminino".

Desta forma, o texto deixa claro o que pode ser considerado crime de gênero, ou em relação à condição feminina, onde aparecem a violência doméstica e familiar e o menosprezo à condição de mulher. A lei ainda acrescenta alguns agravantes que servem para aumentar ainda mais a pena, levando em consideração se o crime foi cometido durante a gestação, contra pessoa menor de 14 ou maior de 60 anos, e se o mesmo ocorrer na presença de descendente ou ascendente da vítima. 
A lei 13.104/15 também operou uma modificação importante no artigo $1^{\circ}$ da lei 8.072/90, de crimes hediondos, a qual ficou com a seguinte redação: “Art. $1^{\circ}$ São considerados hediondos os seguintes crimes, todos tipificados no Decreto-Lei no 2.848, de 7 de dezembro de 1940 - Código Penal, consumados ou tentados". Sendo assim, o feminicídio, crime praticado contra a mulher, derivado de sua condição feminina, passa a ser tratado com o rigor que merecem os crimes hediondos, conferindo ao mesmo um caráter ainda mais desqualificador como ato infame, motivado por motivo torpe.

É inegável, pois, a virada operada pela lei do feminicídio, no sentido de atacar na raiz a causa maior dos crimes contra a mulher, a saber, a violência de gênero, a tentativa sub reptícia de submeter a mulher à violência constante na certeza de que será perdoado por ter agido em função da paixão, de um arrebatamento emocional qualquer e que, por isso mesmo, serviria de pretexto para pelo menos atenuar a pena destes infratores. Neste sentido, Mariana Armond Dias Paes (2015) afirma que "fica evidente, então, que a violência sofrida pela mulher não é uma violência como outra qualquer, mas ocasionada, principalmente, pela sua condição de mulher e praticada no âmbito doméstico e familiar".

Isto se dá, segundo a autora, pela própria situação de desigualdade vivida pela mulher. Além de receber salários mais baixos em relação ao homem, ela tem que cumprir uma dupla jornada, tendo ainda a responsabilidade pelos afazeres domésticos. Em tais situações, a mulher não consegue desenvolver outras habilidades sociais e por isso mesmo acaba ficando à mercê de seus companheiros, os quais geralmente as tratam de forma a inferiorizá-las.

É esta vulnerabilidade que fomenta a discriminação e a violência desencadeada pelos parceiros e que era de certa forma justificada pela sociedade, na medida em que não legislava de forma correta e justa a este respeito. Isto não significa vitimizar a mulher, colocá-la numa posição de coitada, como é muito comum se falar hoje quando alguém levanta a bandeira dos direitos, sejam eles de qualquer ordem.

O que está em jogo aqui é a questão da proteção contra a agressão injustificada de seus companheiros, os quais, valendo-se de sua condição masculina, empreendem toda a sorte de violência sobre suas companheiras. O Estado precisa trabalhar neste caminho de resguardar as vítimas dos seus agressores, fazendo valer sobre estes todo o rigor da lei, sem margens para justificativas passionais, orientadas pela noção de superioridade do macho, másculo, desbravador, ante a fragilidade da fêmea, receptora, delicada e resignada.

Sob este aspecto importante da lei, Prado e Sanematsu (2017) dizem que:

Para além do agravo da pena, o aspecto mais importante da tipificação, segundo especialistas, é chamar atenção para o fenômeno e promover uma compreensão mais 
acurada sobre sua dimensão e características nas diferentes realidades vividas pelas mulheres no Brasil. (PRADO; SANEMATSU, 2017, p. 56).

Mais importante do que a dureza assumida pela legislação, foi sua função pedagógica, no sentido de mostrar as raízes da violência contra a mulher, colocar às claras toda a gama de relações sociais que a justificavam e que, por isso mesmo, levavam a sociedade a resignar-se com tais cenas de violência sexista.

A condição feminina passa então a ser vista com outros olhos, numa espécie de valorização suprema desta realidade, a qual não é escolhida, mas que deve ser respeitada, resguardada em toda a sua riqueza social, cultural e simbólica.

\section{ENTRE A LEI E A RE ALIDADE: A ATUAÇÃO DO ESTADO NO ENFRENTAMENTO DO FEMINICÍDIO}

Se não restam dúvidas sobre a importância da lei 13.104/15, ainda sobram dúvidas quanto à sua efetividade, visto que os homicídios contra as mulheres continuam a acontecer, muitas vezes ainda sendo justificados com o argumento da passionalidade, como se a lei não tivesse nenhuma funcionalidade. Na verdade, a grande questão é fazer com que a estrutura do Estado, totalmente voltada para a proteção e justificação da violência perpetrada pelos homens possa agora voltar-se efetivamente para a garantia de proteção da mulher.

As delegacias especializadas em violência contra a mulher representam um grande avanço neste sentido. Os núcleos de apoio, as políticas governamentais, a criação de uma secretaria executiva para as mulheres no âmbito do poder federal, representam passos importantes. É preciso dar mais celeridade e confiança às vítimas, para que elas possam recorrer às instâncias da justiça, sempre que forem vítimas da violência de seus parceiros. É sabido que aquelas que são agredidas nem sempre vão em busca da ajuda policial necessária e ao não buscarem a justiça acabam encorajando seus companheiros violentos a permanecerem com estas atitudes covardes.

Isso não quer dizer que elas fazem isto porque gostam de apanhar, ou porque são cúmplices dos seus algozes, mas muitas vezes é fruto do receio que as mesmas têm em relação à efetiva proteção que lhes será dada pelos órgãos judiciais. Isso faz com que parte desta violência fique invisível, não compondo as estatísticas oficiais das esferas municipais, estaduais e federais. É a violência invisível, que ocorre no seio familiar, mas que não encontra eco nos meios de comunicação, nos números revelados pelas secretarias que tratam do combate à violência doméstica ou mesmo as secretarias de defesa social, responsáveis pela segurança pública. 
Neste sentido, é muito importante retirar o selo de problema privado concernente às agressões sofridas pelas mulheres por parte dos seus companheiros. Estamos diante de um problema social, que precisa ser resolvido a partir da esfera pública, estatal, governamental. Esta tarefa foi inicialmente confiada às organizações em defesa da mulher, como nos fala Eva Alterman Blay (2003) em seu artigo sobre a Violência contra a mulher e políticas públicas, no qual ela diz que:

Ao longo das décadas de 1960 e 1970, feministas de classe média, militantes, políticas contra a ditadura militar e intelectuais foram se somando a sindicalistas e trabalhadoras de diferentes setores. Certamente, unidas numa visão democrática e igualitária dos direitos da mulher que suplantava diferenças partidárias e ideológicas. Formou-se um vasto movimento unido de mulheres, se considerarmos que o inimigo era comum. (BLAY, 2003, p. 45).

A formação destes movimentos foi importante, no sentido de dar visibilidade à demanda das mulheres, encorajando muitas delas a sair da penumbra e gritar por seus direitos, exigindo da sociedade um tratamento igualitário com relação aos seus direitos, que eram desrespeitados em face dos privilégios concedidos aos homens. E não só isso, como nos diz Blay (2003):

\begin{abstract}
Ao movimento feminista se aglutinou uma série de grupos que atuaram cotidianamente a favor dos direitos a melhores condições de vida, pela anistia, pela igualdade de direitos entre homens e mulheres. A formação de entidades voltadas a abrigar mulheres vítimas de violência doméstica não tardou a se formar. Por todo o Brasil grupos de ativistas, voluntárias, procuravam enfrentar todos os tipos de violência: estupros, maus tratos, incestos, perseguição a prostitutas, e infindáveis violações dos direitos humanos de mulheres e meninas. Diferentemente das décadas de 1910 e 1920, agora as denúncias destes crimes escondidos na e pela família tornaram-se públicos. Recebidos inicialmente com descrédito e sarcasmo pela mídia em geral, aos poucos foram reconhecidos. (BLAY, 2003, p. 53).
\end{abstract}

Graças a estes movimentos, os casos de violência começaram a vir à tona, a ser denunciados, o que ocasionou uma maior cobrança dos poderes públicos no sentido de seu empenho na solução destas ocorrências. Concomitante a isto foram sendo criados os conselhos de defesa da mulher, bem como as delegacias especializadas na sua proteção, fato muito relevante, pois possibilitou um tratamento diferenciado destes crimes. As delegacias comuns, quase sempre tratavam mal as mulheres, achando inclusive que as vítimas de violência eram merecedoras das mesmas. Desta forma, a mulher chegava a uma delegacia e era atendida por policiais homens, que destilavam sobre ela toda a sua visão preconceituosa e machista.

Todas estas iniciativas são fundamentais no sentido de dar maior visibilidade ao problema da violência contra a mulher, mas mostram o quanto o poder público ainda precisa se aproximar desta realidade, criando mecanismos legais e institucionais para combater a realidade presente do feminicídio em nosso país. 


\section{CONSIDERAÇÕES FINAIS}

Estamos vivendo um período em que a violência aumenta a cada dia, tornando nossas cidades lugares perigosos de se viver. Mas no caso da violência de gênero, as vítimas são atacadas não apenas nos espaços públicos, mas também no ambiente doméstico, onde em tese deveriam encontrar todo apoio e aconchego necessário ao seu desenvolvimento físico e psicológico.

Os traumas causados pelos atos de violência são muitos. Os casos registrados de crimes relacionados ao gênero mostram famílias devastadas, esfaceladas por causa de um gesto de desespero e desrespeito de alguém que se acha no direito de tirar a vida de sua parceira apenas por considerá-la sua propriedade ou por achar que deve proteger a sua honra masculina.

As mulheres ainda sentem dificuldades de fazerem a denúncia contra seus agressores, em parte por vergonha, em parte por medo de uma retaliação ainda mais forte do seu companheiro. Para muitas mulheres é difícil expor sua vida e escancarar as agressões que sofreram da parte dos seus companheiros.

Não deve ser fácil apresentar à sociedade as sequelas físicas provocadas por um ato infame de violência. É muito importante lutar para superar a cultura da violência que já se instalou na sociedade e, sobretudo, entre os casais. São estas práticas e ideias machistas que acabam criando um ambiente propício à violência masculina. É difícil imaginar que uma mulher deseje ser agredida. A violência e o assassinato de mulheres é uma chaga que ainda faz parte de nossa realidade. São fatos como estes que nos fazem refletir cada vez mais sobre a importância de se criar cada vez mais mecanismos de proteção às mulheres, pois elas são as vítimas preferenciais de um modelo machista e patriarcal de sociedade.

Este artigo mostrou as bases históricas e sociais que fundamentam o comportamento agressivo dos homens frente às mulheres, além de apresentar a evolução legislativa, que teve na Lei Maria da Penha um dos momentos principais e que redundou na importante Lei do Feminicídio.

Não há como contestar o avanço representado por estes documentos legais. A partir de então, a mulher passou a ter maior atenção e proteção da parte do Estado brasileiro. Em um Estado democrático de direito é de grande relevância que as leis contribuam para corrigir as distorções e desigualdades sociais.

No que concerne à violência contra a mulher, esta se dá por vários motivos e de inúmeras formas, desde o ato puro e simples do companheiro até o tratamento inadequado nas delegacias especializadas. Com o advento da Lei Maria da Penha, começaram a se espalhar as 
delegacias especializadas da mulher, que passaram a oferecer um tratamento mais adequado às vítimas.

Tal fato reforça a necessidade de se continuar aperfeiçoando os instrumentos legais, bem como os mecanismos capazes de lhes dar cumprimento. Neste sentido, e é sempre bom reforçar este aspecto, não basta apenas a letra da lei. É necessária sua efetivação, ou seja, que ela seja aplicada na prática e que o cidadão seja alcançado por seus benefícios.

No que concerne à Lei do Feminicídio, o endurecimento da pena e sua tipificação como crime hediondo representou um passo importante no combate às práticas cotidianas de violência contra a mulher, além de estabelecer um paralelo com o elemento sociológico presente nestas formas de agressão.

Tudo isto acaba direcionando a discussão para a condição da mulher em nossa sociedade, o que é sumamente relevante. Quando se debate o feminicídio, vem à tona o modelo de sociedade que se construiu ao longo dos séculos, que distribui privilégios aos homens e coloca a mulher em condição subalterna, devendo aceitar e assumir a culpa por ter sido agredida.

Portanto, cabe não apenas validar a lei, por meio dos instrumentos institucionais. É necessário repensar o modelo de sociedade que foi construído ao longo dos séculos e que faz com que o homem se ache no direito de agredir a mulher. Não há como dissociar a criação de um arcabouço legal e punitivo do processo educativo. Uma das formas mais eficazes, embora mais difícil e duradoura de se combater o feminicídio, é investir na educação, na formação ética. Isso requer alguns movimentos importantes.

Primeiro, é necessário estruturar a família, de modo a que os filhos sejam educados com base no respeito às diferenças de gênero, para que a mulher não seja mais vista como um ser subalterno. Por ser a base da sociedade, a entidade familiar precisa assumir seu papel de formadora, de criadora dos primeiros fundamentos de uma relação de respeito, no qual os papéis desempenhados por homens e mulheres sejam vistos à luz da ética, do respeito mútuo, fomentando a cultura da não violência.

O segundo trabalho importante se faz por meio da educação formal. A escola também precisa assumir seu protagonismo no que diz respeito à criação de um pensamento que proponha o respeito à mulher. Há que se realizar todo um trabalho de desconstrução da mulher como objeto sexual e posse do homem. Algumas disciplinas, como ética e cidadania, por exemplo, precisam ser mais valorizadas nos currículos escolares e os alunos precisam ser chamados a debater estas questões com profundidade. 
E o terceiro movimento diz respeito às ações governamentais. É de grande relevância realizar campanhas de conscientização em relação à violência contra a mulher. O Estado precisa assumir seu papel nesta jornada, fomentando o debate e chamando a atenção para a realidade. Quanto mais se debater o tema, melhor. As ações governamentais devem se dirigir ao combate firme e incansável contra as múltiplas formas de violência de gênero.

Cabe destacar também o papel das universidades, enquanto espaço plural, que acolhe e estimula a reflexão sobre os graves problemas sociais. É uma tarefa urgente e necessária, que não pode mais ser adiada. Apesar dos avanços, ainda há em nossa sociedade uma cultura de violência, que atinge principalmente as mulheres, que muitas vezes ainda são acusadas de serem as responsáveis pela violência que sofrem. Mudar este cenário é uma tarefa da sociedade e um imperativo ético.

\section{REFERÊNCIAS}

BLAY, Eva Alterman. Violência contra a mulher e políticas públicas. Estud. av. vol.17 n.49, São Paulo. Set./Dez. 2003. Disponível em: http://dx.doi.org/10.1590/S010340142003000300006 Y Acesso em: 10 nov. 2020.

BRASIL. Constituição da República Federativa do Brasil. Brasília, DF: Senado Federal: Centro Gráfico, 1988. 292 p.

Lei 11.340 de 07 de agosto de 2006. Lei Maria da Penha. Disponível em: www.planalto.gov.br. Acesso em: 16 out. 2020.

Lei 13.104 de 09 de março de 2015. Lei do Feminicídio. Disponível em: http://www.planalto.gov.br/ccivil_03/_ato2015-2018/2015/lei/113104.htm. Acesso em: 14 out. 2020.

DIAS, Maria Berenice. A Lei Maria da Penha na justiça: a efetividade da Lei 11.340/2006 de combate à violência doméstica e familiar contra a mulher. 2. ed. São Paulo: Editora Revista dos Tribunais, 2010.

FON, Lays Conceição Franco. Violência contra a mulher: notas sobre o feminicídio em Salvador/BA. UFRPE, 2014. Disponível em: http://www.ufpb.br/evento/lti/ocs/index.php/18redor/18redor/paper/view/674/702. Acesso em: 20 out. 2020 . 
FURQUIM, Saulo Ramos. A mulher no direito penal: Breves considerações à Lei $\mathrm{n}^{\mathrm{o}}$ 11.340/06. In: Âmbito Jurídico, Rio Grande, XVII, n. 130, nov. 2014. Disponível em: http://www.ambito-juridico.com.br/site/?n_link=revista_artigos_leitura\&artigo_id=15457.

Acesso em: 16 nov. 2020.

PRADO, Débora; SANEMATSU, Marisa. (Org.) Feminicídio: \#invisibilidademata. Ilustração: Lígia Wang. Fundação Rosa Luxemburg. São Paulo: Instituto Patrícia Galvão, 2017.

MINAYO, Maria Cecília de Souza (2005). Laços perigosos entre machismo e violência. Revista Ciência \& Saúde Coletiva, 10(1):23-26. Disponível em: http://www.scielo.br/pdf/csc/v10n1/a03cv10n1. Acesso em: 15 out. 2020.

PAES, Mariana Armond Dias. Inclusão do feminicídio no Código Penal é uma questão de igualdade e gênero. Conjur, 2015. Disponível em: https://www.conjur.com.br/2015.../mariana-paes-feminicidio-questao-igualdade-genero.

Acesso em: 22 nov. 2020.

SAFIOTTI, Heleieth. Gênero, patriarcado e violência. São Paulo: Editora Fundação Perseu Abramo, 2004.

SANTIAGO, Rosilene Almeida; COELHO, Maria Thereza Ávila Dantas. A violência contra a mulher: antecedentes históricos. In: Revista UNIFACS, 2007. Disponível em: www.revistas.unifacs.br/index.php/sepa/article/download/313/261. Acesso em: 19 out. 2020. 


\title{
INOVAÇÃO E MUDANÇAS DE PARADIGMAS ATRAVÉS DA GESTÃO 4.0 NA BUSCA DO DIFERENCIAL COMPETITIVO NAS ORGANIZAÇÕES
}

\author{
https://dx.doi.org/10.48097/2674-8673.2021n5p12
}

Ana Paula Barbosa de Oliveira ${ }^{1}$
Djailton Paz Dias da Silva ${ }^{2}$
Susimary Leitão

RESUMO

O objetivo deste trabalho é destacar a inovação e as mudanças de paradigmas através da gestão 4.0 na busca do diferencial competitivo nas organizações, investigando os elementos intervenientes da tomada de decisão. Para isso é necessário compreender as peculiaridades da inovação tecnológica, analisando as abordagens relevantes sobre a gestão eficiente, evidenciando as mudanças tecnológicas sob os aspectos da cultura organizacional. A metodologia apresentada neste trabalho foi elaborada com base em pesquisa bibliográfica, explorativa, qualitativa, visando fundamentar teoricamente os conceitos com base em autores renomados. Ficou constatado que os gestores possuem responsabilidades dentro das organizações a fim de empregar uma abordagem de mudança no gerenciamento de processos que ajude a organização a se adaptar às mudanças introduzidas pela implementação de soluções e inovações tecnológicas.

Palavras-chave: Inovação. Mudanças. Gestão 4.0. Diferencial Competitivo.

Data de submissão: 26/03/2021

Data de aprovação: 05/05/2021

\begin{abstract}
The objective of this work is to highlight innovation and paradigm changes through 4.0 management in the search for competitive advantage in organizations, investigating the intervening elements of decision making. For this, it is necessary to understand the peculiarities of technological innovation, analyzing the relevant approaches on the management of efficient changes, highlighting technological changes under aspects of organizational culture. The methodology presented in this work was developed based on bibliographic, exploratory, qualitative research, aiming to theoretically base the concepts based on renowned authors. It was found that managers have responsibilities within organizations in order to employ an approach to change in process management that helps the organization to adapt to the changes introduced by the implementation of technological solutions and innovations.
\end{abstract}

Keywords: Innovation. Changes. Management 4.0. Competitive Differential.

\footnotetext{
${ }^{1}$ Concluinte do Curso de Gestão em Recursos Humanos da Faculdade Metropolitana da Grande Recife.

E-mail: anapaulabarbosa19993@gmail.com

${ }^{2}$ Concluinte do Curso de Gestão em Recursos Humanos da Faculdade Metropolitana da Grande Recife.

E-mail: djjaisilva@gmail.com

${ }^{3}$ Professora Orientadora do Curso de Gestão em Recursos Humanos da FMGR.

E-mail: susimary@gmail.com
} 


\section{INTRODUÇÃO}

A primeira revolução industrial consistiu na mecanização dos processos de produção por meio de dispositivos e máquinas de água e vapor em um campo tecnológico, o que resultou em uma mudança drástica em todos os aspectos da vida humana. Nessa ordem de ideias, a segunda revolução industrial marcou novas formas de produção em massa e de organização das empresas, além de começar a usar a eletricidade como energia.

A terceira revolução industrial se destaca pelo uso de computadores para automatizar esses processos de produção, mas apenas em termos de força bruta. Os computadores controlavam automaticamente as máquinas que realizavam o trabalho físico que exigia força bruta. Não havia inteligência real aplicada e nenhuma análise. Basicamente, o trabalho físico estava mudando para máquinas automatizadas.

Essa quarta revolução difere das anteriores, pois as tecnologias, além de obviamente mais avançadas, caracterizam-se por serem de natureza inteligente em termos de coleta e análise de dados, aprendizado de máquina, comunicação em rede, entre outros aspectos tecnológicos. Isso implica avanços importantes na computação e em outras áreas científicas que permitem que os computadores se tornem cada vez mais automáticos e inteligentes.

A justificativa deste trabalho está pautada na gestão 4.0, nas decisões descentralizadas, que são definidas como a capacidade dos sistemas de tomar decisões inteligentes por conta própria, com base em informações. Um exemplo disso é um sistema embarcado inteligente que, ao receber dados de sensores, decide, através de um mecanismo previamente programado, se deve acelerar ou reduzir a produção, alcançando assim um diferencial competitivo no mercado no qual atua.

O objetivo geral deste trabalho é destacar a inovação e mudanças de paradigmas através da gestão 4.0 na busca do diferencial competitivo nas organizações. Já os objetivos específicos são estudar o diferencial competitivo, investigar os elementos intervenientes da tomada de decisão na gestão 4.0, compreender as peculiaridades da inovação tecnológica, analisar as abordagens relevantes sobre a gestão de mudanças eficientes, evidenciar as mudanças tecnológicas sob os aspectos da cultura organizacional e, por fim, abordar os desafios e perspectivas na gestão das indústrias 4.0 frente às mudanças tecnológicas. 


\section{UM OLHAR SOBRE O DIFERENCIAL COMPETITIVO}

De acordo com Rumelt (2011), o mercado concorrencial, nos dias de hoje, tem impulsionado as organizações a buscarem vantagens competitivas para se destacarem de seus concorrentes. Como consequência, o conceito de vantagem competitiva aparece consideravelmente nas discussões que envolvem estratégias de negócios empresariais.

Existe dificuldade para a definição de um conceito que defina na sua totalidade a expressão vantagem competitiva, no entanto, parece ser muito utilizada a associação deste com o tema da criação de valor. (RUMELT, 2011).

Porter (1980 apud Magretta, 2018) discorre que as vantagens competitivas são o elo fundamental da performance de uma empresa em mercados dinâmicos e competitivos. Assim, as vantagens competitivas geram custos baixos de vantagens diferenciais, ou de uma estratégia bem sucedida focada no sucesso organizacional.

De acordo com o Rumelt (2011), diferentes organizações de consultoria em estratégias fazem a análise de vantagem competitiva em termos de retornos obtidos aos acionistas. No entanto, a estratégia competitiva tem oferecido um número muito reduzido de técnicas analíticas para a obtenção de sua compreensão, sendo que economistas estudam há muito tempo as estruturas empresariais com grandes perspectivas da política pública aliada aos interesses das organizações.

Braga (2010) destaca que:

Os agentes do mercado incluíam compradores, fornecedores e produtores. Os
ganhos totais negociáveis estariam maximamente disponíveis pela atribuição entre
os agentes. Eles concluíram que o valor máximo apropriado é limitado pelo valor
agregado de cada agente para o jogo, com o valor total do jogo sendo incrementado
pela presença dos agentes. Para a obtenção de um valor agregado positivo, um
participante deve ser diferente de seus competidores, sendo detentor de uma
assimetria positiva. (BRAGA, 2010, p. 13).

Já de acordo com Barney (2011), a estratégia de uma empresa é definida como a sua teoria de como obter vantagem competitiva, embora seja difícil predizer a maneira exata como a competição em um setor evoluirá e, portanto, raramente é possível saber com certeza se uma empresa está escolhendo a estratégia certa, por isso, a estratégia de uma empresa é quase sempre uma teoria, ou seja, é a sua melhor aposta sobre como a competição vai se desenvolver e como essa evolução pode ser explorada para que conquiste a vantagem competitiva. 
Figura 1 - Modelo de pedras angulares de vantagem competitiva

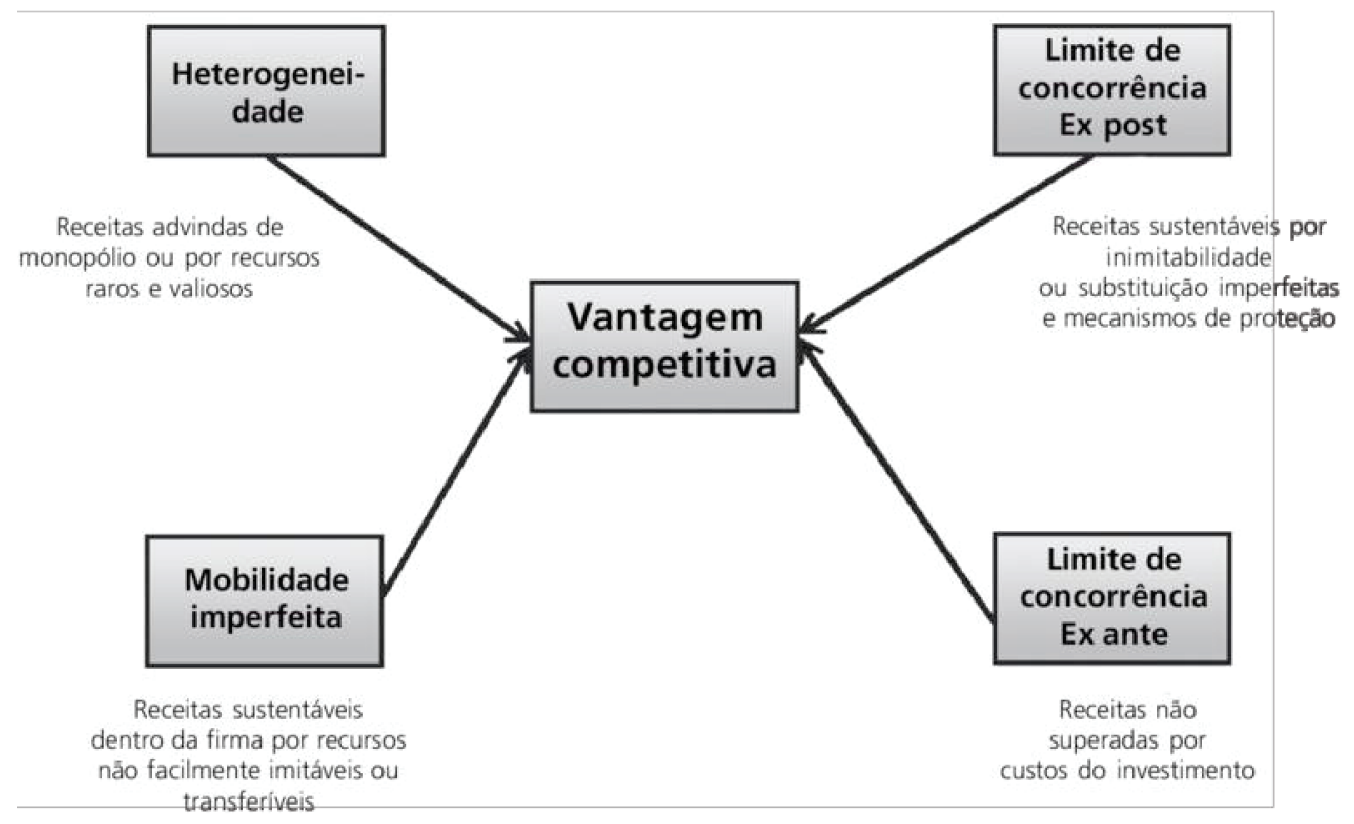

Fonte: adaptado de Braga (2010)

Embora seja difícil saber com certeza se uma empresa está seguindo a melhor estratégia, é possível reduzir a probabilidade de erros. Diante disso, a melhor maneira é escolher a estratégia da empresa de forma cuidadosa e sistemática, além de acompanhar o processo de administração estratégica, constituída por um conjunto sequencial de análises e escolhas que podem aumentar a probabilidade de uma empresa escolher uma boa estratégia, isto é, uma estratégia que gere vantagens competitivas. (BARNEY, 2011).

Conforme pensamento de Porter (1980 apud Magretta 2018), o desempenho de qualquer empresa pode ser dividido em duas partes: a primeira, originada do desempenho médio de todos os concorrentes; e a segunda, originada do desempenho relativo da empresa do setor. $\mathrm{O}$ alinhamento de todas as atividades de uma organização em torno de uma estratégia competitiva torna mais fácil a sua implementação e comunicação com clientes, empregados e acionistas. Um posicionamento estratégico que não seja claro, sem explicação, dificulta a construção dos recursos necessários, criando problemas de coordenação interna. Dessa forma, a posição mais crítica em termos de posicionamento estratégico seria a região central.

De acordo com Magretta (2018), a rivalidade competitiva é um processo implacável que combate a capacidade da empresa de identificar e manter uma vantagem, porém existem conceitos errôneos sobre competição e, como esta funciona, dão origem a erros em estratégia, 
dentre eles, o mais comum é de que o sucesso competitivo resulta de ser o melhor, sendo essa mentalidade altamente intuitiva e também autodestrutiva.

Segundo Porter (1980 apud Crainer, 2015), a abordagem sobre estratégia vinculou-se do sucesso ao posicionamento, dividindo o ambiente competitivo em cinco forças, sendo elas: 'rivalidade entre concorrentes', 'poder de negociação dos fornecedores', 'poder de negociação dos clientes', 'ameaça de produtos entrantes' e 'ameaça de produtos substitutos', as quais as empresas devem estar atentas, fazendo algumas considerações sobre como as empresas podem utilizar sua avaliação para adotar uma que assegure maior vantagem estratégica.

A estratégia de vantagem competitiva está ligada ao modo como a empresa organiza suas atividades, pois se utiliza de uma abordagem baseada em sistemas para dissecar a análise das atividades de uma empresa e o modo como ela usa suas atividades para criar valor. Como coloca Porter, o valor é criado quando uma empresa utiliza recursos à sua disposição para transformar insumos em produtos ou serviços que os consumidores possam adquirir. (PORTER, 1980 apud CRAINER, 2015).

\section{Elementos intervenientes da tomada de decisão na gestão 4.0}

A tomada de decisão, independentemente da estratégia adotada, implica na avaliação de alternativas que envolvem riscos. A tomada de decisão arriscada está carregada de incertezas que existem quando as pessoas não sabem o que acontecerá. (WEITEN, 2008). Com o propósito de reduzir incertezas e melhorar as decisões, os indivíduos deveriam basear suas decisões em processos racionais, estabelecendo a resposta mais coerente para determinada solução do problema. (BAZERMAN, 2004).

No século passado era comum encontrarmos líderes que centralizavam o poder de decisão neles mesmos, pois não acreditavam na capacidade de seus subordinados. Poucos eram os líderes que, diante da necessidade de delegar tarefas, descobriam que seus subordinados possuíam habilidades de tomar decisões. Hoje, os líderes se esforçam em motivar os seus subordinados, capacitando-os com informação, treinamento, confiando a eles tarefas complexas, pois as informações chegam em nosso meio de forma muito mais rápida. Diante disso, nas organizações do novo século, o homem é parte de uma rede de pensadores e comunicadores, sendo a tarefa principal do líder motivar e manter essa rede funcionando. Portanto, as informações que eram desprezadas no passado, hoje devem ser mostradas a todos os colaboradores da organização no qual todos representam um fator de crescimento para a organização. (BAZERMAN, 2004). 
Os métodos de administração e de gestão sofrem mudanças ao longo dos anos, entretanto, prevalece o trabalho individualizado, resultando em uma competição entre as pessoas, porém quando o trabalho tem o foco em equipe, a gestão se torna participativa. O processo de tomada de decisão é necessário para identificar as questões envolvidas e descobrir alternativas com o uso da criatividade e da capacidade analítica, avaliando assim as ações a serem tomadas e descobrir alternativas disponíveis através da gestão participativa ao alterar conceitos como trocar o chefe pelo líder. Ao mudar a postura e a maneira de atuar, todos os empregados deixam de ser meros executores e passam a gerir seu trabalho e contribuir na gestão da empresa, adotando assim a forma de trabalho através de equipes, atuando de forma coesa, integrada e participativa. (BAZERMAN, 2004).

As decisões dentro da organização que possui uma gestão 4.0 podem ser classificadas quanto à atividade administrativa a que ela pertence seguindo três níveis:

- Nível operacional: utilização eficaz e eficiente das instalações existentes e todos os recursos para executar as operações. A decisão de nível operacional é um processo pelo qual se assegura que as atividades operacionais sejam bem desenvolvidas.

- Nível tático: engloba a aquisição genérica de recursos e as táticas para a localização de projetos e novos produtos. As decisões, no nível tático, são normalmente relacionadas com o controle administrativo.

- Nível estratégico: envolve a definição de objetivos, políticas e critérios gerais para planejar o curso da organização. O propósito das decisões, no nível estratégico, é desenvolver estratégias para que a organização seja capaz de atingir seus macro objetivos. (ANTHONY, 1965, p. 180).

De acordo com Bazerman (2004), o modelo racional de tomada de decisão está fundamentado em elementos que definem a forma pela qual a decisão deve ser tomada, e não como ela realmente é. O modelo de tomada de decisão, segundo o autor, é apresentado nas seguintes fases:

1) Definição do problema;

2) Identificação dos critérios relevantes para a tomada de decisão;

3) Ponderação dos critérios, atribuindo preferências;

4) Conhecimento de todas as alternativas relevantes;

5) Avaliação das alternativas de a cordo com os critérios identificados para cada decisão;

6) Identificação da melhor solução.

Muito embora decidir seja uma ação em si no sentido lato, diferencia-se da implementação por ser um caminho de ação já escolhido, mas que ainda precisa ser concretizado no decorrer do tempo. Portando, decidir diferencia-se da implementação no 
sentido preciso do exame laboral, havendo lapsos de tempo maiores ou menores conforme a posição da hierarquia das decisões. (ABRAHAN, 2011).

Nas decisões estratégicas há mais distinção e implementação enquanto na decisão operacional a ação e a decisão praticamente se confundem. Em contrapartida, uma separação ou integração mais precisa entre decisão e ação dependerá de exame mais analítico do contexto que envolve a decisão do líder. (ABRAHAN, 2011).

Segundo Robbins (2014):

O fato é que, diferentemente do que acontece na maioria das indústrias hoje, em uma gestão 4.0 todos os dados da empresa estarão disponíveis para acesso em tempo real. A partir desse ponto, deve-se preocupar com a extração de informações úteis desses dados para que, efetivamente, se alcance a precisão nas tomadas de decisão esperada para a Indústria 4.0 Os dados coletados pelos sistemas tecnológicos da Indústria 4.0 são de grande importância para a tomada de decisões, mas não geram informações de valor por si só. É necessário que estes sejam encaminhados a profissionais capazes de analisá-los e interpretá-los, transformando dados crus em decisões fundamentadas e que tragam benefícios e diferencial competitivo para a empresa. (ROBBINS, 2014, p. 41).

Kazmier (1975 apud Abrahan 2011) afirma de forma pragmática que a habilidade em tomar decisões é a chave do planejamento bem sucedido em todos os níveis de gestão, sendo que isso envolve mais que uma seleção de planos de ação, havendo assim pelo menos três fases: diagnóstico, descobertas de alternativas, e análises.

\section{As peculiaridades da inovação tecnológica}

Desde os anos 1950 o Brasil vem estruturando sua rede de base para ciência, tecnologia e inovação. Diante disso, surgiram inúmeras organizações e, consequentemente, leis e políticas públicas para alavancar a inovação, prioritariamente nas pequenas e médias empresas brasileiras. Entretanto, a cultura, o cenário burocrático brasileiro, o financiamento público e privado limitado, a falta de infraestrutura para o desenvolvimento das ideias, o desconhecimento da aplicação das leis e políticas de incentivos, impedem que a inovação seja deslanchada para níveis adequados ao desenvolvimento pretendido no país. (TERRA, 2019).

Além dos itens descritos como atividades de inovação, os custos e os riscos foram apontados, de acordo com o IBGE (2018), como uma das principais dificuldades para se inovar no Brasil, pois estão relacionados com gastos dispendidos pelas empresas em relação ao PIB, uma vez que como os custos e riscos são elevados há uma tendência de que os gastos nesse processo de inovação sejam menores.

As empresas dependem dos ambientes internos e externos para a sua manutenção e desenvolvimento. Terra (2019) frisa que a interação entre universidades, governo e empresas 
é altamente relevante para a inovação acontecer, principalmente de cunho tecnológico, conseguindo estabelecer paradigmas organizacionais, entre elas as incubadoras de empresas.

No Brasil existem dois principais incentivos ficais à inovação nas empresas: incentivos fiscais P\&D em qualquer setor industrial, previstos na LB, no capitulo III, regulamentada pelo decreto 5.798/2006, acrescida da lei 11. 487/2007, regulamentada pelo decreto 6.260/2007; e Lei 11.774/2008, porém o correto entendimento e interpretação dos artigos e parágrafos inclusos nas respectivas leis podem ser um diferencial para utilizar ou não um incentivo fiscal, nos quais os contabilistas podem ajudar a diminuir as diferenças e dificuldades entre os empresários inovadores por não se tratar de uma tarefa simples. (TERRA, 2019).

\section{Abordagens relevantes sobre a gestão de mudanças eficientes}

De acordo com Johann (2018), em um mundo globalizado, no qual as organizações estão diante do recorrente desafio de se adequar aos novos tempos, elas se caracterizam por sucessivas mudanças que se processam no macroambiente. Efetuar adequações na cultura e na estratégia da empresa é algo que merece atenção da alta administração da organização. As mudanças que se processam no macroambiente geram instabilidade, mas também comportam oportunidades para novos negócios, produtos e serviços.

A sobrevivência de todo e qualquer tipo de empresa não mais depende do porte de cada organização, mas decorre, ao longo dos anos, de sua capacidade de se adaptar aos novos tempos. Portanto, deve-se ter em mente que a gestão da mudança não implica necessariamente em uma drástica mudança cultural, mas sim em um processo de gradual ajustamento e de suporte da cultura da empresa ao projeto de mudança organizacional palnejada. (JOHANN, 2018).

Quando a empresa se dispõe a demandar o gerenciamento da sua cultura, sintonizando-a com os processos de mudanças planejadas, há condições de criar e de manter atitude coletiva energizada, entusiástica e assertiva no quadro funcional da empresa. (JOHANN, 2018). 
Figura 2 - Evolução da gestão da mudança organizacional

\begin{tabular}{|c|c|}
\hline Definiçăo encontrada & Referência \\
\hline $\begin{array}{l}\text { Conjunto de teorias, valores, estratégias e técnicas cientificamente embasadas, } \\
\text { visando mudança planejada do ambiente de trabalho com o objetivo de elevar o } \\
\text { desenvolvimento individual e o desempenho organizacional. }\end{array}$ & $\begin{array}{l}\text { Porras e } \\
\text { Robertson } \\
(1992)\end{array}$ \\
\hline $\begin{array}{l}\text { Acontecimento temporal estritamente relacionado a uma logica, ou ponto de vista } \\
\text { individual, que possibilita às pessoas pensarem e falarem sobre a mudança que } \\
\text { percebem. }\end{array}$ & $\begin{array}{l}\text { Ford e Ford } \\
\text { (1995) }\end{array}$ \\
\hline $\begin{array}{l}\text { Resposta da organização às transformaçōes que vigoram no ambiente, com o intuito } \\
\text { de manter a congruência entre os componentes organizacionais (trabalho, pessoas, } \\
\text { arranjos/estrutura e cultura). }\end{array}$ & $\begin{array}{l}\text { Nadler et al. } \\
\text { (1994) }\end{array}$ \\
\hline $\begin{array}{l}\text { Qualquer transformaçăo de natureza estrutural, estratégica, cultural, tecnológica, } \\
\text { humana ou de outro componente, capaz de gerar impacto em partes ou no } \\
\text { conjunto da organizaçăo. }\end{array}$ & Wood Jf. (2000) \\
\hline $\begin{array}{l}\text { Qualquer modificação, planejada ou nåo, nos componentes organizacionais formais } \\
\text { e informais mais relevantes (pessoas, estruturas, produtos, processos e cultura); } \\
\text { modificaçăo que seja significativa, atinja a maioria dos membros da organizaçăo } \\
\text { e tenha por objetivo a melhoria do desempenho organizacional em resposta às } \\
\text { demandas intemas e externas. }\end{array}$ & Bressan (2001) \\
\hline
\end{tabular}

Fonte: adapatado de Bourne (2014)

A gestão de mudanças envolve, de acordo Bourne (2014), quatro elementos no processo de tranformação:

1) Analisar a necessidade de mudança e decidir como deveria ser, com base em analises;

2) Planejar e administrar a mudança como um projeto ou uma série de projetos;

3) Implementar a mudança e gerenciar as pessoas por meio dela;

4) Assegurar que a mudança se torne bem enraizada de modo que não seja arruinada.

Administrar a mudança, em termos gerais, resume-se em persuadir as pessoas a trabalhar de maneira diferente, seja com um equipamento novo, de uma nova estrutura ou com um diferente conjunto de processos, agindo de forma concreta sobre como fazer e agir, a fim de evitar imprevistos. Certamente, quanto mais claro for o retrato do objetivo a ser alcançado, mais capaz de conquistar o compromisso de outros em relação às metas organizacionais. (BOURNE, 2014).

Segundo Bourne (2014), se a organização não muda em resposta ao ambiente em que opera, irá fracassar. Do mesmo modo as pessoas têm que mudar e se adaptar conforme as circunstancias. Gerenciar a mudança é uma tarefa difícil e dolorosa, podendo ser até emocionalmente desgastante, envolvendo uma gama de habilidades desde o planejamento de 
projetos, passando a influenciar aqueles que provavelmente serão afetados, até assegurar que as ações apropriadas aconteçam.

\section{As mudanças tecnológicas sob os aspectos da cultura organizacional}

A única forma efetiva de mudar a organização é através de sua cultura, pois a sua sedimentação está ligada ao processo do conhecimento e relacionada por intermédio da construção de significados. Na realidade, não se tem uma única cultura nas organizações, pois o correto a se dizer nos dias atuais se coloca como as culturas presentes em uma organização, evidenciando, assim, a preocupação na relação com os outros, focando na necessidade de entender contextos e questões que se alteram a cada discurso incorporado pelas pessoas nas organizações. (GARCIA, 2015).

O tema cultura organizacional tem ganhado relevância nos últimos anos, tanto pelo crescimento no número de pesquisas, quanto pelo enfoque teórico metodológico. Os controles baseados em cultura sob a perspectiva de relação com os controles gerenciais formais constituem o ambiente no qual os demais controles se inserem. Trata-se de um fenômeno complexo e que compreende diferentes fatores, de modo que se tem desenvolvido modelos em que se agrupam várias características da cultura em duas dimensões, resultando em diversos tipos culturais. (MENEGON, 2012).

A cultura organizacional molda os comportamentos sociais, como destaca Garcia (2015), exercendo o papel de incentivadora ou inibidora de práticas e formas de conduta, de modo que tem sido estudada com sua relação com o desempenho e como parte do sistema de controle gerencial.

Ainda de acordo com Garcia (2015), a cultura organizacional não pode ser abordada explicitamente porque é considerada antes como um fator contingente, uma variável de contexto, um elemento de controle em que esse autor propõe um modelo de análise de sistemas de gerenciamento de desempenho.

As organizações devem se preocupar com o monitoramento das informações e a abertura do diálogo com seus diferentes grupos de interesses, entendendo que o seu comportamento deve ir muito além do repasse de informações, tendo consistência da sua cultura, para que todos tenham acesso. (MENEGON, 2012).

Como destaca Silva (2015):

A relação entre tecnologia, inovação e produção do conhecimento, bem como suas dimensões no contexto organizacional vêm evoluindo ao longo do tempo, desta forma, vale-se da história para resgatar questões que nesta perspectiva permanecem contemporâneas, impactando na estrutura de gestão das empresas modernas. Entende-se que a compreensão desse processo por parte das empresas/organizações 
contribuirá para a busca de modelos, métodos ou práticas inovadoras que levem em conta a importância da produção do conhecimento para a geração de inovação. No decorrer do último século as mudanças no mundo do trabalho têm ocorrido de forma vertiginosa, alterando estruturas, hierarquia, tecnologias e as exigências sobre os trabalhadores, levando os dirigentes a efetuarem constantes mudanças em suas organizações com o objetivo de mantê-las estáveis, eficientes e em desenvolvimento. (SILVA, 2015, p. 32).

A cultura organizacional pode ser fortemente caracterizada por ter grande influência do modo de como as pessoas pensam e se comportam e que, consequentemente, todos acreditam e atendem às metas e práticas da empresa, principalmente na área de inovação e tecnologia. É uma verdadeira vantagem para a organização se os comportamentos que encorajam e facilitam forem apropriados. O ponto fraco de uma cultura organizacional que encoraja comportamentos errados é dificultar gravemente os esforços da empresa para operar as mudanças adequadas. (MENEGON, 2012).

\section{Os desafios e perspectivas na gestão das indústrias 4.0 frente às mudanças tecnológicas}

A indústria e suas várias revoluções, sem dúvida, mudaram completamente a maneira como a humanidade trabalha. A primeira revolução industrial ocorreu em 1760, no final do século XVIII. Essa grande mudança ocorreu na Grã-Bretanha e depois se espalhou para o resto da Europa. A economia começou a depender da produção local, embora, no início, não estivesse acostumada ao mercado internacional. Essa nova forma de economia mudou o cenário social e a estrutura de classes. (SANTOS, 2018).

A segunda revolução industrial ocorreu em 1870. Sem dúvida, com o surgimento da energia elétrica, todo o cenário mundial é completamente mudado. Organizações capitalistas foram estabelecidas com força, a mídia sofreu mudanças abismais, assim como o transporte. Os produtos de eletricidade e petróleo começaram a substituir rapidamente a energia do vapor. (SANTOS, 2018).

A terceira revolução foi apenas alguns anos atrás, no final do século 20, com o surgimento da eletrônica e do mundo da internet. Essa foi uma mudança radical na maneira como as pessoas se comunicavam e entendiam a sociedade. Com essa mudança, o que foi mais revolucionado foram os meios de comunicação que continuam cada vez mais aperfeiçoados. (SANTOS, 2018).

Está a caminho uma quarta revolução industrial. Por vários anos a ideia de robótica foi refinada e é possível que a próxima grande mudança que a indústria tenha sobre a humanidade esteja intimamente ligada a essa questão. Diante disso, a indústria remove os fundamentos da 
humanidade toda vez que se reinventa. É isso que estamos vendo com a manufatura aditiva, uma nova mudança de paradigma na produção. (SANTOS, 2018).

Segundo Sacomano (2018), com a indústria 4.0 nos referimos ao movimento tecnológico caracterizado por uma rede de conexão de computadores na qual ocorre uma troca permanente e instantânea de informações, além do estreito vínculo entre computadores do mundo real e do mundo virtual. Nesse sentido, esses avanços tecnológicos são enquadrados nos contextos comercial e industrial, de modo a melhorar a qualidade dos processos industriais e melhorar a produtividade dessas organizações, com base no desenvolvimento e aumento do poder de computação dos dispositivos.

O desenvolvimento de sensores e comunicações sem fio, bem como o desenvolvimento do potencial computacional, permitem o desenvolvimento e a experimentação de tecnologias emergentes, como a realidade virtual e a realidade aumentada. No caso da visão artificial, é uma tecnologia que usa câmeras para capturar imagens e vídeos cujos dados capturados são usados pelos computadores para processá-los. (SACOMANO, 2018).

Para Almeida (2019), no setor industrial, apesar de os sistemas de realidade aumentada ainda estarem em estágios muito iniciais de seu desenvolvimento tecnológico, eles são capazes de fornecer serviços no nível industrial, como a seleção de peças do armazém, reparo e manutenção, treinamento e montagem das máquinas.

O novo paradigma tecnológico estabelecido e que está começando a se desenvolver na indústria 4.0 terá um impacto progressivo em todos os aspectos da vida humana. O desenvolvimento de tecnologias vinculadas a sensores, poder computacional e o desenvolvimento de algoritmos de reconhecimento de imagem são uma oportunidade para empresas de todo o mundo promoverem e facilitarem o crescimento e o acesso a essas tecnologias para melhorar a produtividade, não apenas em um quadro de referência industrial, mas também para o consumo do público além do entretenimento. (ALMEIDA, 2019).

\section{METODOLOGIA}

Trata-se de um estudo realizado através da pesquisa bibliográfica de caráter exploratório e descritivo. Para a realização da mesma foi efetuado um levantamento de publicações científicas relacionadas com a temática da pesquisa. O critério de inclusão dos artigos foi ser trabalho de pesquisa publicado em periódicos nacionais em língua portuguesa.

Foram consultadas as bases de dados informatizadas: o portal SCIELO (Scientific Eletronic Library Online) e livros. Durante a coleta e análise foram encontrados artigos e 
livros com publicações que atendiam aos objetivos propostos, sendo excluídos os que na leitura do resumo não apresentavam relação com o tema da pesquisa.

Para síntese e análise do material foram realizados os seguintes procedimentos: leitura exploratória, que constitui na leitura do material para saber do que se tratavam os artigos; leitura seletiva, que se preocupou com a descrição e seleção do material quanto a sua relevância para o estudo; leitura crítica e reflexiva, que buscou por meio dos dados a construção dos resultados encontrados.

Este estudo tem como base a pesquisa exploratória, pois a "investigação exploratória é realizada em área na qual há pouco conhecimento acumulado e sistematizado". (MASCARENHAS, 2013).

Desenvolvida com base em material já elaborado como livros, artigos e teses, a pesquisa bibliográfica possui caráter exploratório, pois permite maior familiaridade com o problema, aprimoramento de ideias ou descoberta de intuições. No caso específico de pesquisas avançadas onde se exige certo ineditismo e originalidade na contribuição, a revisão bibliográfica desempenha um papel preponderante. (GIL, 2007).

\section{RESULTADOS}

A apresentação e a análise dos dados servirão, como primeiro passo, para saber em que estado se encontra atualmente o problema, que trabalhos já foram realizados a respeito, e quais são as opiniões reinantes sobre o assunto. Como segundo passo, permitirá que se estabeleça um modelo teórico inicial de referência, da mesma forma que auxiliará na determinação das variáveis e na elaboração do plano geral da pesquisa. (MASCARENHAS, 2013).

A globalização atual está causando à economia mundial um profundo processo de mudança. As empresas têm buscado aplicar estratégias para minimizar os impactos ambientais negativos de seus produtos e processos, ao mesmo tempo em que intensific am sua competitividade. Um dos diferenciais das empresas é o lançamento antecipado dos produtos e a capacidade de desenvolvê-los com os objetivos de atender às crescentes necessidades e expectativas dos clientes.

O evento que desencadeia a mudança pode ser a adoção de uma nova estratégia, tecnologia, organização ou habilidade, ou na melhor das hipóteses, esse evento pode ser uma oportunidade para a organização alcançar o sucesso, tendo assim como principal foco no desempenho humano, ou seja, ajuda a organização a capturar o benefício de uma 
oportunidade, influenciando o desempenho humano para se obter uma gestão de mudança eficaz.

Na gestão 4.0 as mudanças podem ser aplicadas através de muitas ideias diferentes dos campos de negócios, como desenvolvimento organizacional e psicologia, uma vez que as mudanças nas organizações se tornam mais frequentes para a sobrevivência, incluindo a liderança de mudanças tecnológicas. Também evoluiu pra abranger mais habilidades e conhecimentos no qual a avaliação de desempenho serve para mensurar os mesmos, facilitando a sua administração.

Figura 3 - Principais impactos e mudanças após a adoção de uma gestão 4.0

\begin{tabular}{l|l}
\multicolumn{1}{c|}{ En 2015 } & \multicolumn{1}{c}{ En $\mathbf{2 0 2 0}$} \\
\hline 1- Solução de problemas complexos & \multicolumn{1}{c}{ 1- Solução de problemas complexos } \\
2- Relacionamento com os outros & 2- Pensamento crítico \\
3- Gestão de pessoas & 3- Criatividade \\
4- Pensamento crítico & 4- Gestão de pessoas \\
5- Negociação & 5- Empatia com os outros \\
6- Controle de qualidade & 6- Inteligência Emocional \\
7- Orientação para serviços & 7- Bom senso e tomada de decisões \\
8- Bom senso e tomada de decisões & 8- Orientação para serviços \\
9- Escuta ativa & 9- Negociação \\
10- Criatividade & 10- Flexibilidade Cognitiva \\
\end{tabular}

Fonte: Adaptado de Johann (2018)

Constatando que na gestão 4.0 as mudanças não podem ser um trabalho somente para uma pessoa ou uma única equipe, os papéis necessários para realizar o plano de gestão de mudanças incluem executivos, líderes, especialistas de RH, colaboradores e recursos designados em uma equipe de projetos em que a avaliação do sucesso das mudanças se mede através do grau dos objetivos da transformação alcançados.

\section{CONSIDERAÇÕES FINAIS}

Ficou constastado no decorrer desse trabalho, ao atingir seus objetivos, que os gestores possuem responsabilidades dentro da organização a fim de empregar uma abordagem de mudança no gerenciamento de processos que ajude a organização a se adaptar às mudanças introduzidas pela implementação de soluções e inovações tecnológicas. As organizações cada vez mais sofrem intensivo impacto das tecnologias, pois a automação avança rapidamente tanto nos escritórios como nos processos industriais, atingindo, incluisive, as indústrias mais tradicionais.

Diante disso, observa-se que toda a economia moderna dependerá cada vez mais da ciência e da tecnologia, no qual assumem uma posição estratégica com profundas implicações 
nas tomadas de decisões, pois nas próximas décadas não haverá nação verdadeirmaente soberana que não disponha de um eficiente sistema de ino vação tecnologica na vanguarda das organizações.

A tranformação digital é a nova corrida do ouro em busca de vantagem competitiva para garantir a sustentabilidade das organizações ao redor do mundo. Por questão de sobrevivência, no ambiente dos negócios, as empresas estão acelerando o passo para realizarem mudanças, até mesmo em sua cultura organizacional, em prol das inovações. Porém, ainda existem diversas lacunas e incertezas quanto ao futuro. A boa utilização da tecnologia é a questão central na busca pelo aumento de produtividade nas organizações, auxiliando a levar informação para os decisores na forma e no tempo adequado, obtendo assim um diferencial competitivo, mesmo nos tempos de mudanças originadas pelos avanços tecnologicos.

\section{REFERÊNCIAS}

ABRAHAN, S. O. Y. Tomada de decisão nas organizações. São Paulo: Editora Saraiva, 2011.

ALMEIDA, P. S. Industria 4.0: princípios básicos, aplicabilidade e implantação na área industrial. São Paulo: Editora Saraiva, 2019.

ANTHONY, R. N. Planning and Control Systems. Cambridge: Havard University Press, 1965.

CRAINER, S. Estratégia: arte e ciência na criação e execução. Porto Alegre: Bookman, 2015.

BARNEY, J. B. Administração estratégica e vantagem competitiva. São Paulo: Editora Pearson, 2011.

BOURNE, M. Gestão de mudanças em uma semana. São Paulo: Figurati, 2014.

BRAGA, A. Strategic Sourcing: a transformação estratégica das empresas compradoras - parte 1. Artigos Instituto ILOS: Rio de Janeiro, 2010.

BAZERMAN, M. Processo decisório. Rio de Janeiro: Campus, 2004.

GARCIA, A. B. Influência da cultura organizacional na gestão participativa nas organizações. Rio de Janeiro: Revista de Pesquisa Cuidado é Fundamental. v. 7, n. 2. AbrilJunho, 2015.

GIL, A. C. Métodos e técnicas de pesquisa. São Paulo: Editora Atlas, 2007. 
JOHANN, S. L. Gestão de mudança e cultura organizacional. Rio de Janeiro: FGV, 2018.

MASCARENHAS, S. Metodologia Científica. São Paulo: Pearson Educational do Brasil, 2013.

MAGRETTA, J. Entendendo Michael Porter. Rio de Janeiro: Alta Books, 2018.

MENEGON, L. F. Comportamento organizacional. São Paulo: Editora Pearson, 2012.

ROBBINS, S. P. Fundamentos do comportamento organizacional. São Paulo: Pearson Educational do Brasil, 2014.

RUMELT, R. P Estratégia boa, estratégia ruim: descubra suas diferenças e importância. São Paulo: Elsevier, 2011.

SACOMANO, J. S. Industria 4.0. São Paulo: Blucher, 2018.

SANTOS, S. Introdução à indústria 4.0. São Paulo: Editora Atlas, 2018.

SILVA, N. Percepções dos gestores sobre os comportamentos dos funcionários em situações de mudanças tecnológicas. Curitiba: Psicologia Dossiê, 2015.

TERRA, B. Inovação. Rio de Janeiro: Edição dos autores, 2019.

WEITEN, W. Introdução à psicologia. São Paulo: Cengage Learning, 2008. 


\title{
A LOGÍSTICA REVERSA CONTRIBUINDO PARA A MITIGAÇÃO DOS IMPACTOS AMBIENTAIS: UM ESTUDO DE CASO
}

\author{
https://dx.doi.org/10.48097/2674-8673.2021n5p13
}

\author{
Aline Gabrielle da Silva ${ }^{1}$ \\ Claudenize Silva Soares ${ }^{2}$ \\ Elias Meireles de Brito ${ }^{3}$ \\ Leticia Andrade da Silva ${ }^{4}$ \\ Susimary Leitão ${ }^{5}$
}

\section{RESUMO}

O presente artigo tem como objetivo apresentar os benefícios econômicos e ambientais obtidos com a implantação da Logística Reversa no grupo Meta 55 / Net Distribuidora. Para tanto, de forma exploratória, conduziu-se um estudo de caso, escolhendo como objetivo de análise o Centro de Distribuição da Meta 55. Foi realizada uma visita técnica guiada e entrevista aberta com os responsáveis pelo setor logístico da empresa. Verificou-se comparativamente a leitura existente e a realidade de sua aplicação na empresa. Ao final, apesar de não permitir conclusivamente pela natureza da pesquisa, foi possível identificar, mesmo assim, que o processo de logística reversa é resultado do comprometimento da empresa com seus ambientes interno e externo. Este artigo enumerou algumas razões para a empresa adotar esta prática de Logística Reversa, sendo uma fonte de vantagem competitiva para uma estratégia empresarial, chegando, assim, a obter redução de custos, de espaço e tempo em suas atividades.

Palavras-chave: Logística reversa. Fraldas descartáveis. Impactos ambientais.

Data de submissão: 19/04/2021

Data de aprovação: 21/05/2021

\begin{abstract} Center for Goal 55 as an analysis objective. A guided technical visit and an open interview with those responsible for the company's logistics sector was carried out. The existing reading

\footnotetext{
${ }^{1}$ Discente do Curso de Graduação Tecnológica em Logística da Faculdade Metropolitana.

E-mail: alinegabrielle@gmail.com

2 Discente do Curso de Graduação Tecnológica em Logística da Faculdade Metropolitana.

E-mail: nizepernambucana@hotmail.com

${ }^{3}$ Discente do Curso de Graduação Tecnológica em Logística da Faculdade Metropolitana.

E-mail: eliasmeireles1010@gmail.com

${ }^{4}$ Discente do Curso de Graduação Tecnológica em Logística da Faculdade Metropolitana.

E-mail: lety 15 a@hotmail.com

${ }^{5}$ Docente orientadora do Curso de Graduação Tecnológica em Logística da FMGR.

E-mail: susimary@gmail.com
}

This article aims to present the economic and environmental benefits obtained with the implementation of Reverse Logistics in the group Meta 55 / Net Distribuidora. For this purpose, in an exploratory way, a case study was conducted, choosing the goal of Distribution and the reality of its application in the company were verified comparatively. In the end, despite not allowing conclusively due to the nature of the research, it was still possible to 
identify that the reverse logistics process is the result of the company's commitment to its internal and external environments. This article enumerated some reasons for the company to adopt this practice of Reverse Logistics, being a source of competitive advantage for a business strategy, reaching, thus, obtaining a reduction in costs, space and time in its activities.

Keywords: Reverse logistics. Disposable diapers. Environmental impacts.

\section{INTRODUÇÃO}

A crescente demanda populacional ocorrida nas últimas décadas traz à tona a crescente problemática do lixo. Segundo dados da última edição do estudo Panorama dos Resíduos Sólidos no Brasil, são gerados anualmente 72,50 milhões de toneladas. Dessas, cerca de 42,6 milhões de toneladas são de resíduos sólidos urbanos. 58,7\% do material coletado seguiu para aterros sanitários, enquanto 29,90 milhões de toneladas de resíduos foram direcionados para locais inadequados como lixões que não possuem sistemas necessários para a proteção do meio ambiente. (ABRELPE, 2011).

A logística reversa faz com que o produto, parte ou resíduos voltem para a origem onde foi produzido para que possa ser reutilizado na produção de novos produtos ou agregados, favorecendo a preservação do meio ambiente, pois o material que seria descartado em lixões, aterros sanitários ou em locais de descarte ilegal volta ao ciclo produtivo para ser reaproveitado.

O tema sobre logística reversa, apesar da sua importância, ainda não possui uma literatura tão ampla quanto o gerenciamento do fluxo tradicional de matérias (da matériaprima ao cliente final consumidor).

Diante disso, a META 55 / NET DISTRIBUIDORA, sendo um grupo brasileiro dedicado à comercialização de produtos higiênicos e de consumo, principalmente na linha infantil, vive a presente preocupação com a reciclagem e com seu retorno ao destino correto.

O presente trabalho tem como foco a análise da destinação dos resíduos (papel, plástico, papelão) que são gerados na empresa, concentrando no modo como ele é feito e, principalmente, no motivo pelo qual o programa é desenvolvido. Será analisado até que ponto a empresa faz a destinação dos resíduos por obrigações legais ou por determinação da sua política interna.

Dentro do ambiente organizacional, a logística exige, por si só, a necessidade de as empresas obterem uma estratégia que seja bastante ligada aos "3R" (reduzir, reciclar e reutilizar), uma vez que a mesma é uma ferramenta voltada para a ecologia e que tem como 
intuito o reaproveitamento dos recursos adventos do consumo do último setor da cadeia de suprimentos, que são os clientes finais.

A logística reversa foi estabelecida com o objetivo de atender às necessidades de recolhimento de materiais devido ao pós-consumo e pós-venda. Com isso, pode-se afirmar que essa área da logística empresarial é a responsável por controlar o fluxo reverso dos materiais, após eles concluírem os seus ciclos de vidas úteis, na qual são agregados valores financeiros e sustentáveis, a lém de transmitir uma imagem corporativa legal para empresa.

No mesmo ponto, é possível perceber na Lei n. 12.305 a Política Nacional de Resíduos Sólidos, de 2 de agosto de 2010, que define como resíduos sólidos os materiais, substâncias, objetos ou bens descartados, resultante de atividades humanas ou empresariais, em sociedade, cuja destinação final se procede ou deve proceder nos estados sólido ou semissólido, ou ainda como gases contidos em recipientes, e líquidos cujas particularidades tornem inviável o seu lançamento na rede pública de esgotos ou em corpos d'agua. Por isso exigem soluções técnicas ou economicamente viáveis em face da melhor tecnologia disponível.

Sendo assim, empresas geradoras de resíduos são responsáveis pela destinação final dos mesmos. Cientes disso, as organizações devem providenciar estratégias voltadas à administração de seus bens após o consumo. Dessa forma, é importante ressaltar que a logística reversa, também conhecida como logística inversa, é de suma importância para as empresas, devido a sua fundamental função ao meio ambiente, à economia da empresa, e à imagem que a mesma passa aos seus clientes e demais colaboradores.

\section{LOGÍSTICA REVERSA}

De acordo com o Council of Supply Chain Management Professionals (CSCMP, 2010), a logística reversa é um segmento especializado que dá ênfase à movimentação e gestão dos produtos e recursos após a venda e a entrega ao cliente, incluindo a devolução para reparação e/ou crédito.

Segundo Stock (1998), a logística reversa se concentra no retorno de produtos, substituição de materiais e também o seu reaproveitamento, a reciclagem aplicada a determinados materiais, dentre outros.

Rogers e Tibben-Lembke (1999) tratam a logística reversa como um processo de planejamento, implementação e controle dos fluxos de matéria-prima, desde a sua origem até o ponto de consumo. Neste caso, o consumidor final. O objetivo é recuperar o valor gasto no produto através do descarte correto dos resíduos originados pelo produto em questão. 
Dentro desses aspectos, trazemos a tabela a seguir com alguns conceitos e/ou abordagens que foram transformados, agregando valor ao decorrer do tempo, alguns já demonstrados neste capítulo sobre logística reversa e que contribuíram para a formação do conceito atualmente mais utilizado:

Tabela 1 - Conceitos e abordagens sobre logística reversa

\begin{tabular}{|l|l|}
\hline Autor & Conceito \\
\hline $\begin{array}{l}\text { C. L. M. (1993, p. } \\
\text { 323) }\end{array}$ & $\begin{array}{l}\text { "Logística reversa é um termo relacionado às atividades envolvidas no } \\
\text { gerenciamento da movimentação e disposição de embalagens e } \\
\text { resíduos". }\end{array}$ \\
\hline Stock (1998, p. 20) & $\begin{array}{l}\text { "Logística reversa: refere-se ao papel da logística no retorno de } \\
\text { produtos, redução na fonte, reciclagem, substituição de materiais, reuso } \\
\text { de materiais, disposição de resíduos, reforma, reparação e } \\
\text { remanufatura". }\end{array}$ \\
\hline $\begin{array}{l}\text { Rogers e Tibben- } \\
\text { Lember (1999, p. }\end{array}$ & $\begin{array}{l}\text { "Processo de planejamento, implementação e controle da eficiência e } \\
\text { custo efetivo de matérias-primas, estoques em processo, produtos } \\
\text { acabados e as informaçóes correspondentes do ponto de consumo para } \\
\text { o ponto de origem com o propósito de recapturar o valor ou destinar à } \\
\text { apropriada disposição". }\end{array}$ \\
\hline $\begin{array}{l}\text { Bowersox e Closs } \\
\text { (2001, p. 51-52) }\end{array}$ & $\begin{array}{l}\text { "[..] Trata-se de um dos objetivos operacionais da logística moderna, } \\
\text { referindo-se a sua extensão além do fluxo direto dos produtos e } \\
\text { materiais constituintes e à necessidade de considerar os fluxos reversos } \\
\text { de produtos em geral". }\end{array}$ \\
\hline
\end{tabular}

Fonte: adaptado de Pereira et al (2013)

Com o passar do tempo, estes conceitos foram sendo reformulados e assim alcançou uma definição que atualmente é a mais complexa e na qual se identifica realmente todos os objetivos da logística reversa que é o conceito formulado por Leite (2009):

Área da logística empresarial que planeja, opera e controla o fluxo e as informações logísticas correspondentes, do retorno dos bens de pós-venda e pós-consumo ao ciclo de negócios ou ao ciclo produtivo, por meio dos canais de distribuição reversos, agregando-lhes valor de diversas naturezas: econômico, ecológico, de imagem corporativa, entre outros. (LEITE, 2009, p. 17).

Segundo Pereira et al (2013), o conceito de logística reversa é definido como uma das áreas da logística empresarial, pois engloba o conceito de logística já tradicional no meio empresarial, dentro de um conjunto de operações e/ou ações interligadas com base na redução de matérias-primas primárias, chegando até o destino final correto dos seus produtos, materiais e embalagens, destinando-os ao seu reuso adequado e/ou produção de energia. Ainda de acordo com o autor, é observado que a logística reversa também é denominada como logística integral ou inversa. 
Rogers e Tibben-Lembke (1999) mostram que o processo logístico reverso, conforme a figura 1, é de grande importância para as organizações, sejam elas agroindustriais, comerciais ou de serviços.

A lei $\mathrm{n}^{\mathrm{o}} 12.305$ de 2/08/2010 define a logística reversa como um instrumento de desenvolvimento econômico e social caracterizado por um conjunto de ações, procedimentos e meios destinados a viabilizar a coleta e a restituição dos resíduos sólidos ao setor empresarial, para reaproveitamento, em seu ciclo ou em outros ciclos produtivos, ou outra destinação final ambientalmente adequada.

Figura 1 - Processo Logístico Reverso

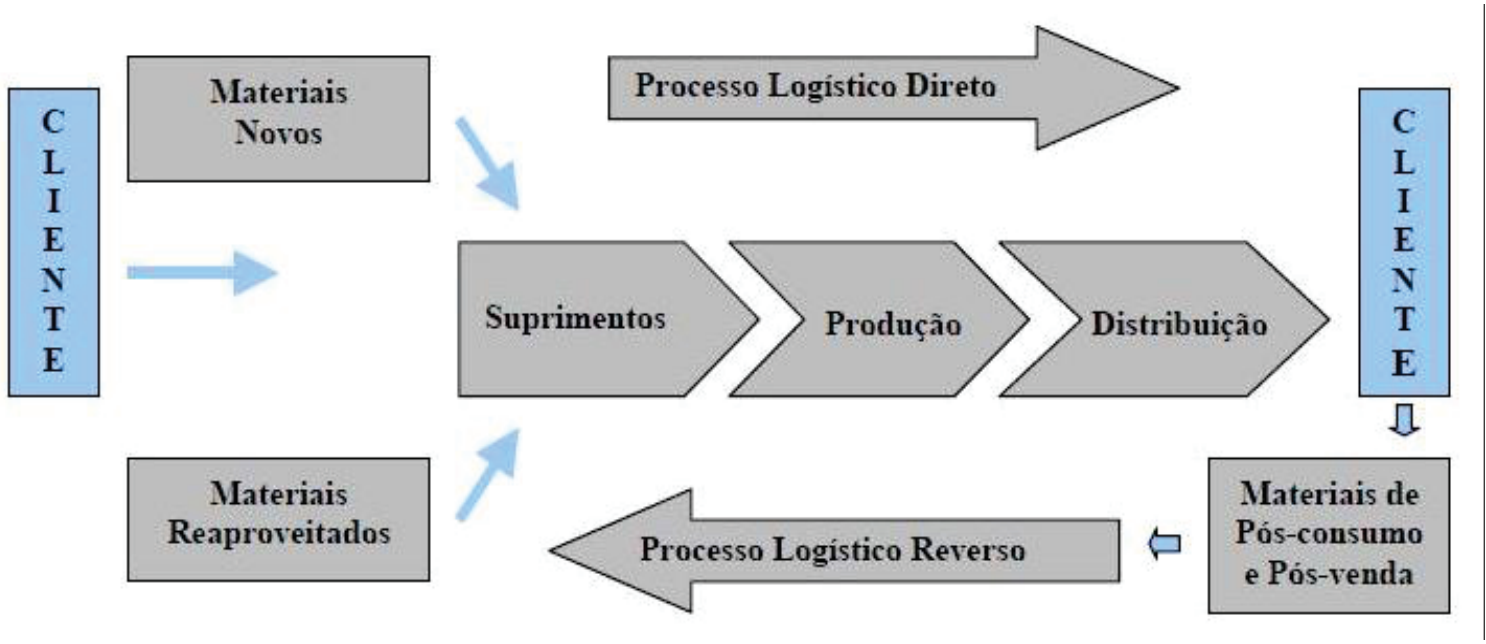

Fonte: adaptado de Rogers \& Tibben-Lembke (1999)

Um conceito geral para explicar a logística reversa é que os produtos consumidos e/ou não utilizados retornam por meio de canais de distribuição, conforme representado na Figura 1. Para Rogers e Tibben-Lembke (1999), assim como nos processos logísticos diretos, o processo logístico reverso faz o planejamento, implementa e controla o fluxo inverso ao fluxo produtivo direto, procurando agregar valor a esses produtos, reintegrando-os ao processo produtivo e de negócios.

\section{Fraldas descartáveis}

As fraldas de pano fizeram parte da vida de muita gente durante muitos anos. Por volta da década de 1980 as fraldas descartáveis passaram a ser mais acessíveis e a atingir um número maior de pessoas. Nas últimas décadas, a praticidade da fralda descartável (infantil e geriátrica) fez com que ela se tornasse essencial na vida da maioria das famílias. O produto, entretanto, passou a gerar discussões sobre seus perigos e impactos ambientais da fabricação 
ao descarte, e começou-se a falar sobre o renascimento das fraldas de pano e nas mais novas opções, que são as fraldas híbridas e as fraldas descartáveis biodegradáveis.

A fabricação de fraldas descartáveis consome muitos recursos e, depois de usadas, elas demoram anos para se decompor. Elas são constituídas por uma proporção significativa de matéria orgânica, além de plástico, fibras e polímero superabsorvente (Super Absorbent Polymer - SAP), tendo grande potencial para reciclagem e podendo ser reutilizado como matéria prima de outros produtos, evitando sua deposição em aterros sanitários ou incinerados (COLÓN et al., 2011; ESPINOSA et al., 2014).

A composição das fraldas descartáveis varia em termos de materiais utilizados e fabricantes (COLÓN et al., 2011). No entanto, Dey et al. (2016), apontam que a estrutura básica de uma fralda descartável consiste em quatro camadas principais.

Figura 2-Estrutura básica e materiais utilizados na fabricação das fraldas descartáveis

Camada Superior

(Polipropileno)

Camada de Aquisição

(Polpa de Celulose, Poliéster)

Camada Absorvente

(Polímero Superabsorvente)

Camada Inferior

(Polipropileno, Polietileno)

Fonte: adaptado de Dey et al. (2016)

A camada superior fica em contato direto com a pele do usuário, sendo composta por polipropileno macio e poroso, desenvolvido para transferir a urina e outros líquidos rapidamente para as camadas inferiores. Essa camada também pode conter loção que ajuda a proteger a pele, evitando desidratação e irritação. A composição de uma fralda descartável pode ser de aproximadamente $43 \%$ de polpa de celulose (celulose $f u f f$ ), $27 \%$ de polímero superabsorvente (PSA), 10\% de polipropileno (PP), 13\% de polietileno (PE), e 7\% de fitas, elásticos e adesivos. Tendo para isso, em sua fabricação, a utilização de recursos como árvores, petróleo, água e produtos químicos.

A camada de aquisição é composta de celulose modificada e poliéster, tendo a função de facilitar a movimentação do líquido para longe da pele, distribuindo-o uniformemente pelo núcleo da fralda. O núcleo da fralda corresponde à camada absorvente, constituída de gel de 
SAP, podendo estar misturado com celulose ou polímero poroso. A urina é bloqueada e armazenada dentro dessa camada. A camada inferior é a parte impermeável, tendo a função de impedir que o líquido escape para a pele. É tipicamente feita de polipropileno de textura macia, semelhante a um tecido, e laminada com uma película de polietileno.

Reciclar um produto é uma medida que agrega valor à marca e promove a preservação ambiental de grande impacto positivo, considerando as dificuldades impostas nesse processo. Especificamente a reciclagem de fraldas vem suprir um setor que tem dificuldades em encontrar uma empresa especializada neste tipo de procedimento.

A reciclagem de fraldas descartáveis é um procedimento ecologicamente correto em que as empresas ambientalmente responsáveis investem em uma destinação final sustentável. Para reciclar fraldas há duas etapas: separação da polpa e separação das sobras.

O primeiro passo é fazer a separação dos materiais, pois cada parte reciclável será enviada para um destino final diferente. Essa separação acontece por meio de uma empresa especializada em reciclagem de fraldas, onde é possível efetuar a separação do produto em máquina específica e apropriada.

\section{Separação da polpa}

Após a separação da polpa é realizada a reciclagem e envio para diversas empresas que utilizam esse material para fabricação de novos produtos, como a fabricação de tapetes higiênicos para linha "pet", além de ser emitido laudo conclusivo com detalhamento do processo.

\section{Separação das sobras}

As sobras são encaminhadas diretamente para as empresas de reciclagem especializadas neste tipo de material. Investir em reciclagem de fraldas é poupar o meio ambiente do contato prejudicial desse tipo de produto que pode levar mais de 500 anos para se decompor.

\section{Impacto Ambiental}

Considerando o contexto da logística reversa, não se pode deixar de citar a preocupação com o meio-ambiente, que é um dos principais fatores que a motivam. Segundo Lacerda (2002), a questão ambiental vem ganhando importância crescente desde a década de 70, quando os consumidores passaram a cobrar das indústrias de bens de consumo ou serviços 
maior consciência ambiental e só a partir da década de 90 é que sua influência se mostrou mais intensa.

Para Butter (2003), a relação da logística reversa com o meio ambiente tem importância porque as constantes movimentações de materiais residuais, provenientes dos processos de fabricação e das devoluções de produtos, poderão causar de alguma forma acidentes ambientais. Então, um sistema de gestão ambiental, quando implantado, fornece ferramentas e procedimentos que serão facilitadores na condução da logística reversa dos resíduos sólidos.

Para Donaire (1999), a questão ambiental nas empresas envolve: produtos obtidos de matéria-prima renováveis ou recicláveis, que não agridam o meio ambiente, e com baixo consumo de energia no processo; processos com poluição controlada, mínima geração de resíduos, nenhum risco para os trabalhadores, baixo consumo de energia e eficiência na utilização dos recursos; conscientização ambiental, com objetivo de ser mais competitivo; padrões ambientais, para gerar novas oportunidades; comprometimento gerencial; capacitação do pessoal, com treinamento em todos os níveis; capacidade da área de pesquisa e desenvolvimento de produtos ecologicamente corretos; e disponibilidade para investimentos em novas tecnologias.

Usualmente, ao se falar em meio ambiente, a definição mais amplamente difundida é um conceito simplista e reducionista desse termo, focando, principalmente, em fatos que ocorrem distantes da realidade, como desmatamentos, espécies em extinção, desertificação, dentre outros. Porém, é imprescindível que se trate o meio ambiente integralmente, e não somente parte dele. (PEREIRA, 2013).

Como define Coimbra (2002), o meio ambiente deve ser visto como um conjunto de elementos bióticos (flora e fauna) e abióticos (físicos e químicos), constituído por todos os ecossistemas, tanto sociais, culturais, econômicos e naturais, em que o ser humano se insere, social e individualmente, num processo de interação responsável com o meio, atendendo às necessidades de desenvolvimento das atividades humanas, à preservação dos recursos naturais e das características essenciais do entorno.

O termo impacto ambiental pode ser definido e aplicado em diversas áreas multidisciplinares, como no âmbito técnico, econômico e legal. A principal definição se dá no âmbito legal, conforme o artigo $1^{\circ}$ da Resolução CONAMA 01/86: 
ambiente, causada por qualquer forma de matéria ou energia resultante das atividades humanas que, direta ou indiretamente, afetam:

I - A saúde, a segurança e o bem-estar da população;

II - As atividades sociais e econômicas;

III - A biota;

IV - As condições estéticas e sanitárias do meio ambiente;

$\mathrm{V}$ - A qualidade dos recursos ambientais.

Segundo Torrejón e Safra (2015), o impacto ambiental pode ser definido como a diferença entre as condições ambientais que existem com a implementação de um projeto e essas condições sem o mesmo. Esta definição não tem um conteúdo técnico ou econômico, mas uma conotação ambiental que compara duas situações futuras hipotéticas, uma com a implementação do projeto e outra sem o mesmo.

\section{Figura 3 - Representação do conceito de impacto ambiental}

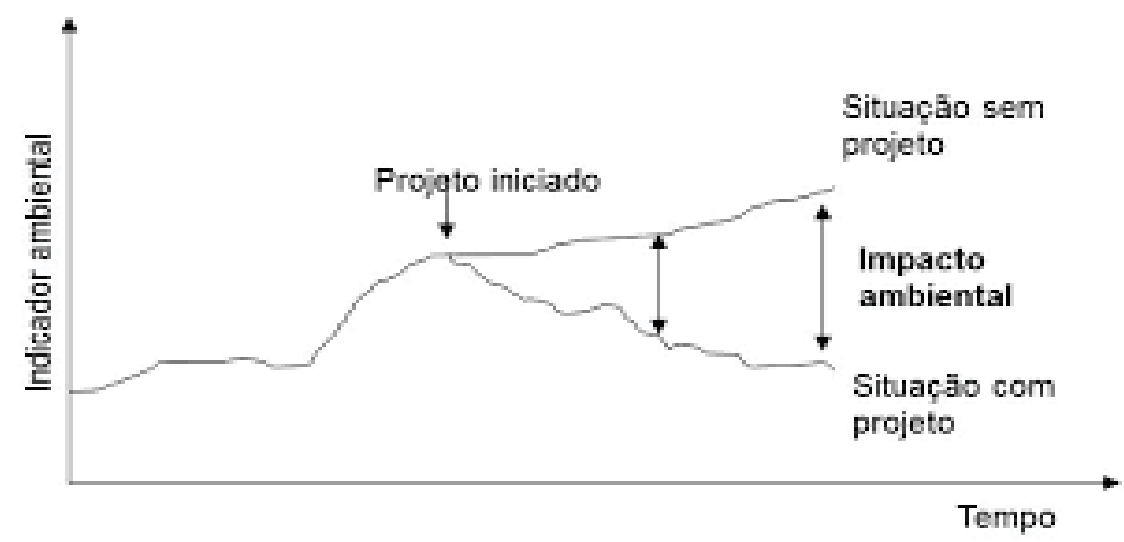

Fonte: Sánchez (2008)

Conforme a figura acima, o termo impacto ambiental refere-se às modificações feitas no ambiente, tanto positivas quanto negativas, ocorridas a partir da introdução de alguma atividade. Para medir esse impacto, deve-se analisar, a partir da observação de algum parâmetro (indicador ambiental), os efeitos no meio ambiente com a realização dessa ação e comparar com a situação futura do meio sem que houvesse essa perturbação.

No processo de avaliação de impacto ambiente (AIA), para simplificação, utiliza-se o conceito operacional de impacto ambiental, que consiste na utilização de indicadores ambientais para avaliar e comparar a diferença da provável situação futura com a situação presente. (SÁNCHEZ, 2008). Nesse contexto, insere-se o conceito de vulnerabilidade do meio, que tem sido usado para descrever a susceptibilidade dos sistemas físicos, biotipos e sociais (TORO et al., 2012).

O conceito de impacto ambiental significativo é aquele que será o foco no processo de AIA que está relacionado ao potencial que tem determinada atividade ou ação humana de causar alterações ambientais. Isso depende de dois fatores: as pressões impostas ao meio pela 
ação ou projeto, ou seja, a sobrecarga imposta ao ecossistema; e a vulnerabilidade do meio, ou seja, o inverso da resiliência, que por sua vez dependerá do estado de conservação do ambiente e das solicitações impostas anteriormente e cujos efeitos se acumularam; ou da importância do ambiente ou do ecossistema. (SÁNCHEZ, 2008). A Figura abaixo exemplifica o conceito de impacto ambiental significativo, relacionando -o com a necessidade do processo de avaliação de AIA para determinado empreendimento.

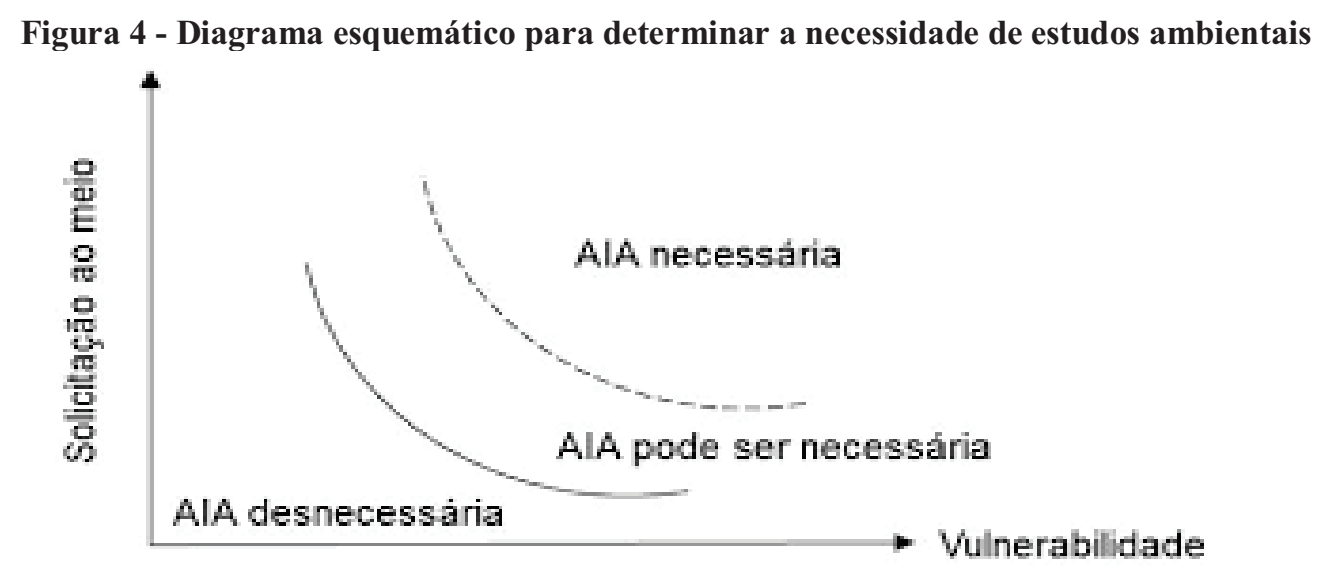

Fonte: Sanchez (2008)

Assim, o potencial de impacto ambiental resulta de uma combinação entre a pressão (característica inerente ao projeto e seus processos tecnológicos) e a vulnerabilidade do meio. (SÁNCHEZ, 2008). Empreendimentos que solicitem muito do meio e que estejam em áreas vulneráveis têm grandes chances de causarem impactos significativos e de necessitarem de AIA para sua implementação. Do mesmo modo, grande pressão de um meio não tão vulnerável também pode causar impactos significativos.

\section{Impactos Ambientais causados pelas Fraldas Descartáveis}

As fraldas descartáveis representam uma grande ameaça ao meio ambiente, pois de sua produção até seu descarte, o uso desse item tão comum já virou alvo de críticas. Para sua produção, além do uso de muita energia e água, é preciso plástico e papel, o que significa que a produção envolve a derrubada de árvores e o uso de um recurso não renovável: o petróleo. Estima-se que, nos três primeiros anos de vida, uma única criança seja responsável pelo uso de seis mil fraldas. Cada uma delas leva cerca de 450 anos para se decompor no meio ambiente.

Segundo dados da Associação Brasileira da Indústria de Higiene Pessoal, Perfumaria e Cosméticos (ABIHPEC), foram 5,6 bilhões de fraldas vendidas ao consumidor no mercado 
brasileiro no ano de 2009 e 7,9 bilhões no ano de 2014. Tendo em vista o ciclo de vida das fraldas descartáveis, além da sua persistência no meio ambiente pós-uso, o produto tem diferentes impactos relacionados a sua produção. Esse ciclo pode ser dividido nas seguintes fases:

- Extração da matéria-prima;

- Fabricação dos materiais;

- Manufatura do produto;

- Disposição final.

Quando descartada no meio ambiente, a parte da fralda composta por celulose pode se decompor em alguns meses, porém os polímeros superabsorventes e os componentes de plástico não podem, o que resulta na persistência desses resíduos no meio ambiente por longos períodos de tempo, possibilitando, quando dispostos em lixões (a céu aberto e sem preparação anterior do solo), a atração de insetos vetores de doenças e a contaminação das águas subterrâneas por micro-organismos presentes nas fezes que foram descartadas com as fraldas.

\section{METODOLOGIA}

O Procedimento inicial escolhido para nortear o presente trabalho foi a pesquisa bibliográfica. Em seguida, foi escolhido como objeto de estudo de caso o processo de logística reversa em uma empresa do setor de comercialização de produtos higiênicos e de consumo em Jaboatão dos Guararapes-PE.

Após a definição do estudo de caso, na terceira etapa, foi estabelecida a realização de uma visita técnica guiada à unidade e uma entrevista aberta com os responsáveis pelo setor de compras.

\section{DESENVOLVIMENTO DA PESQUISA DE CAMPO}

O grupo Meta 55 Distribuidora entende que a Logística Reversa é fundamental para o comércio, pois essa prática significa retornar tudo o que não foi utilizado ao fabricante, liberando assim espaço na distribuidora, o que permite melhor utilização das áreas físicas da companhia.

Segundo relatado pela gestora logística, no período anterior à implementação da prática de logística reversa, existia um problema crônico e crítico a respeito do espaço físico dos armazéns, pois estes estavam sendo subutilizados, com a ocupação de posições 
importantes por avarias, produtos com giro de venda longo, subprodutos ou utensílios logísticos, como pallet, por exemplo.

A partir da identificação desse problema o corpo diretivo da Meta 55 debruçou-se sobre esse sintoma a fim de identificar quais ações deveriam ser tomadas para que a causa raiz fosse tratada e assim o mesmo problema não viesse a se repetir.

Um detalhe importante sobre a implementação da prática da logística reversa é que esta passou a exigir um tratamento diferente, pois o vai e vem de mercadorias, tendo em vista que por este local passava produtos impróprios para a venda, gerava dificuldade tanto para armazenar os demais produtos próprios para a venda como alocar mão de obra operando sem riscos.

Figura 5 - Expedição do centro de distribuição CD da Meta 55

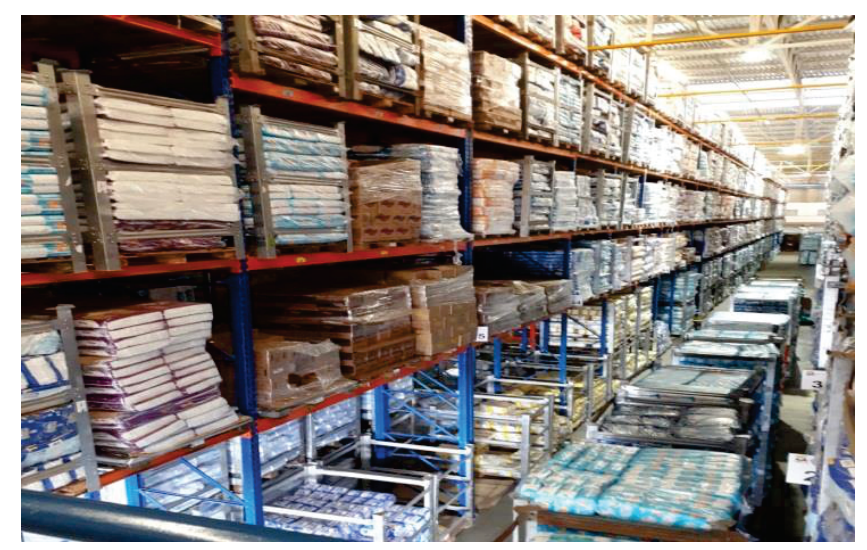

Fonte: Meta 55 Distribuidora

Conforme pode ser observado na foto da expedição do CD da empresa é possível identificar que já está subdimensionada, impossibilitando assim que quando o caminhão retornasse das lojas descarregasse todos os materiais que estavam sendo retornados.

Figura 6 - Doca de abastecimento CD Meta 55

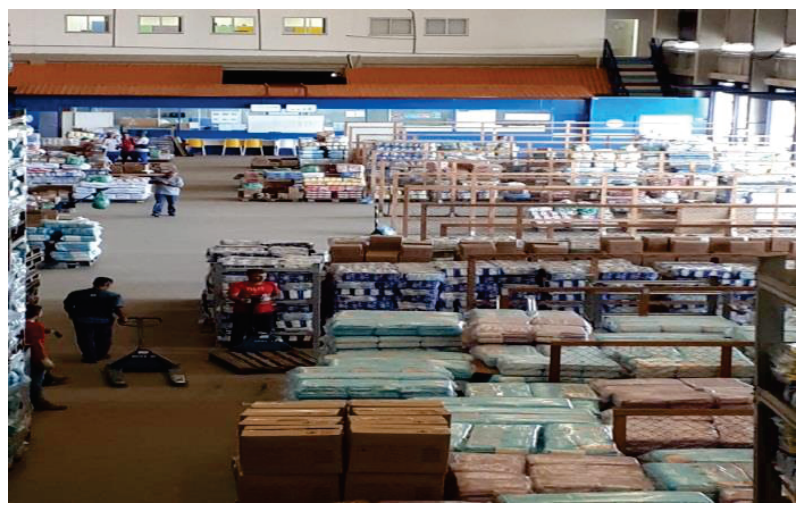

Fonte: Meta 55 distribuidora 
Na figura 6 podemos identificar, mais uma vez, a falta de espaço. Os caminhões já chegam vazios e prontos para o carregamento.

Figura 7 - Classificação da importância da logística reversa na empresa

61 respostas

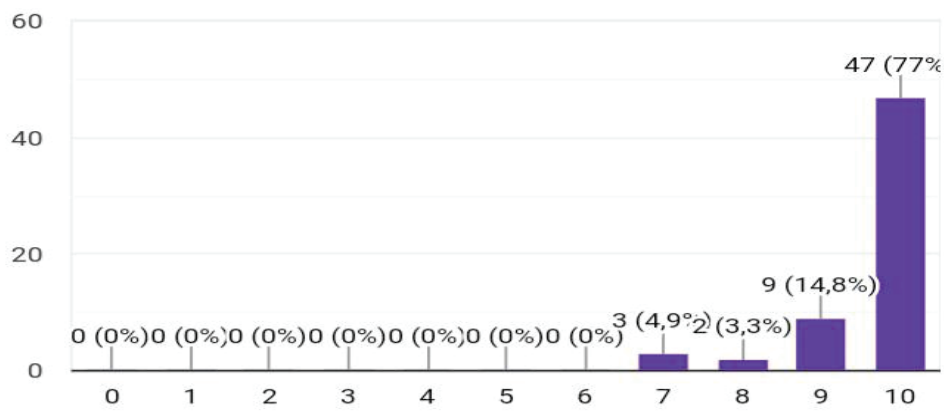

Fonte: Meta 55 Distribuidora

\section{Figura 8 - Colaboradores entrevistados}

61 respostas

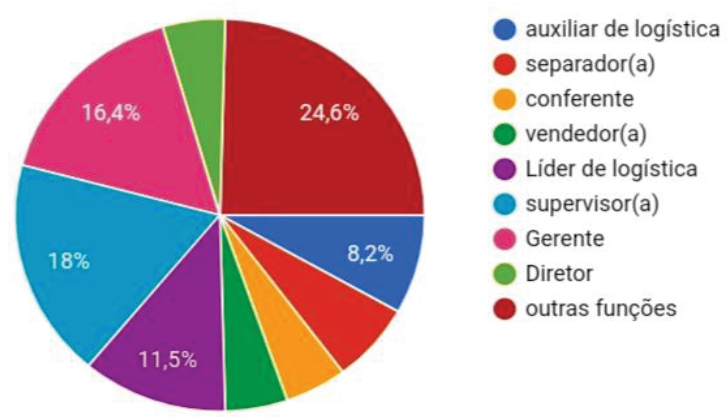

Fonte: Meta 55 Distribuidora

\section{CONSIDERAÇÕES FINAIS}

Este trabalho tinha como pergunta base: quando surgiu a ideia do uso da logística reversa na Meta 55 Distribuidora? Esta pergunta foi devidamente respondida através da visita técnica guiada realizada internamente na empresa pesquisada, levantamento de dados e geração de relatório.

Dessa forma, foi possível demonstrar a diferença do funcionamento que resultou no aumento de faturamento e gestão por logística reversa como uma ferramenta que traz ganhos ambientais à sociedade em geral. 
O objetivo geral do presente trabalho foi a verificação dos benefícios e ganhos econômicos e ambientais, obtidos com a aplicação da prática da logística reversa aplicada no processo de distribuição e armazenagem, no setor de comercialização de produtos higiênicos e consumo.

A empresa se mostrou com perfil inovador ao procurar implementar um modelo próprio de operação de sua logística reversa, também ressaltando o lado resiliente, pois apesar das dificuldades encontradas se manteve firme no objetivo até sua conclusão.

Importante salientar que a coragem e persistência da empresa foram essenciais para o sucesso da operação, visto que a falta de conhecimentos técnicos específicos naquele ramo foram substituídos pela intuição e responsabilidade com os negócios.

\section{REFERÊNCIAS}

ABRELPE. Panorama dos Resíduos Sólidos no Brasil. 2011. Disponível em: https://abrelpe.org.br/download-panorama-2011/. Acesso em: 15 maio 2020.

BUTTER, G. A. Desenvolvimento de um modelo de gerenciamento compartilhado dos resíduos industriais no sistema ambiental da empresa. 2003 f. Dissertação (Doutorado em Engenharia de Produção), Universidade de Santa Catarina, 2003.

COIMBRA, J. A. A. O outro lado do meio ambiente: uma incursão humanística na questão ambiental. Campinas: Millennium, 2002.

COLÓN, J. et al. Possibilities of composting disposable diapers with municipal solid wastes. Waste management \& research, [S.1.], v. 29, n. 3, p. 249-259, 2011.

COLÓN, J. et al. Performance of compostable baby used diapers in the composting process with the organic fraction of municipal solid waste. Waste management, Espanha, v. 33, n. 5, p. 1097-1103, 2013.

CONAMA - Conselho Nacional do Meio Ambiente. Resoluções do Conama: Resoluções vigentes publicadas entre setembro de 1984 e janeiro de 2012. MMA, Brasília, 2012.

CSCMP, Council of Supply Chain Management Professionals. Glossary of Terms. 2010. Disponível

https://cscmp.org/CSCMP/Educate/SCM_Definitions_and_Glossary_of_Terms.aspx. Acesso em: 08 jun. 2020.

DEY, S. et al. Exposure Factor considerations for safety evaluation of modern disposable diapers. Regulatory toxicology and pharmacology, [S.1], v. 81, p. 183-193, 2016.

DONAIRE, Denis. Gestão Ambiental na Empresa. São Paulo: Atlas, 1999. 
ESPINOSA, V, R. M. et al. Biological recycling of used baby diapers in a small-scale composting system. Resources, Conservation and recycling, [S.1.], v. 87, p. 153-157, 2014.

LACERDA, L. Logística reversa, uma visão sobre os conceitos básicos e as práticas operacionais. Centro de Estudos em Logística - COPPEAD - UFRJ - 2002.

LEITE, P. R. Logística Reversa: Meio Ambiente e Competitividade. 2. ed. São Paulo: Prentice Hall, 2009.

PEREIRA, André Luiz et al. Logística reversa e sustentabilidade. São Paulo: Cengage Learning, 2013.

PEREIRA, S. S.; CURI, R. C. Meio Ambiente, Impacto Ambiental e Desenvolvimento Sustentável: Conceituações Teóricas sobre o Despertar da Consciência Ambiental. REUNIR - Revista de Administração, Contabilidade e Sustentabilidade, v. 2, n.4, p.35-57, 2012.

ROGERS, D. S.; TIBBEN-LEMBKE, R. S. Indo para trás: tendências e práticas de logística reversa. Universidade de Nevada. Reno: CLM, 1998.

SANCHÉZ, Luiz Enrique. Avaliação de Impacto Ambiental: conceitos e métodos. São Paulo: Oficina de Textos, 2008. 495p.

STOCK, J. R. Desenvolvimento e Implementação de Programas de Logística Reversa. Estados Unidos da América: Conselho de Manejo Logística, 1998.

TORO, J.; DUARTE, O.; REQUENA, I.; ZAMORANO, M. Determining Vulnerability Importance in Environmental Impact Assessment. The case of Colombia. Environmental Impact Assessment Review, v. 32, n. 1, p. 107-117, 2012.

TORREJÓN, J. A.; SAFRA, P. C. El Impacto Ambiental Negativo y su Evaluación Antes, Durante y Después del Desarrollo de Actividades Productivas. Derecho \& Sociedad, v. 42, p. 223-233, 2015.

\section{APÊNDICE A - Roteiro de perguntas ao gestor}

1. Quando surgiu a ideia do uso da Logística Reversa na Meta 55 Distribuidora?

2. Por qual motivo a Meta Distribuidora optou por este método?

3. Qual a posição da Meta 55 Distribuidora em relação aos impactos ambientais? O que ela pensa para combatê-los?

4. Os funcionários da Meta 55 Distribuidora são instruídos sobre esse método de sustentabilidade? Se sim, de que forma?

5. Você, como Gestor(a) Logístico, encontrou algum ponto negativo ao usar a Logística Reversa na Meta 55 Distribuidora? Se sim, qual? 


\section{APÊNDICE B - Roteiro de perguntas aos colaboradores}

1. Sabendo que a logística reversa é uma ferramenta que tem como objetivo direcionar aquilo que seria desperdiçado para cooperativas e reciclagens, tornando assim o que seria lixo em algo aproveitável ou reutilizável, a empresa que você trabalha utiliza a logística reversa?

2. Qual a sua função na empresa?

3. Você, como funcionário da empresa, acredita ser importante o uso da logística reversa no combate aos impactos negativos ao meio ambiente?

4. Se você fosse gestor de uma empresa, usaria a logística reversa para proteger o meio ambiente?

5. Você acredita que seria importante as empresas utilizarem esse método como um meio sustentável? 


\title{
MARKETING DIGITAL NA CAPTAÇÃO E FIDELIZAÇÃO DE CLIENTES: A VISÃO DE ALUNOS DO CURSO DE ADMINISTRAÇÃO DE UMA INSTITUIÇÃO DE ENSINO SUPERIOR
}

\author{
https://dx.doi.org/10.48097/2674-8673.2021n5p14
}

\author{
Arandi Maciel Campelo ${ }^{1}$ \\ Eryk Marcelo Portela Silva ${ }^{2}$ \\ Eslla Mirely Oliveira Silva ${ }^{3}$ \\ Robson Domingos de Souza ${ }^{4}$
}

\section{RESUMO}

Este artigo foi realizado com base em pesquisas bibliográficas e de campo, em torno da utilização de estratégias de marketing digital na captação e fidelização de clientes, e teve como campo investigativo alunos do curso de administração da Faculdade Metropolitana da Grande Recife - FMGR. O estudo foi centrado em demonstrar as estratégias de marketing digitais que são praticadas pela empresa, à ótica de seus alunos, no ambiente online que funciona como o caminho ideal para o alcance dos objetivos de cada marca, cada instituição, existentes em diversas redes sociais. A investigação bibliográfica foi desenvolvida a partir de estudos de livros, pesquisas em sites e teve, como principal fonte, as bases conceituais de Kotler $(2010 ; 2017)$, dentre outros autores. A pesquisa de campo, realizada em 2020, com aplicação de questionários, através da ferramenta do Google Forms, revelou que qualquer estratégia ou ação que vise captar e fidelizar clientes deve preceder de objetivos de marketing bem definidos, e seu processo de criação e veiculação nas mídias sociais precisam, necessariamente, estar relacionados com o que se espera alcançar de modo alinhado com os propósitos da instituição em estudo.

Palavras-chave: Marketing digital. Captação e fidelização de clientes. Redes sociais.

Data de submissão: $27 / 11 / 2020$

Data de aprovação: 22/02/2021

\section{ABSTRACT}

This article was carried out based on bibliographic and field research, around the use of digital marketing strategies in attracting and retaining customers and had as investigative field

1 Orientador. Doutor em Educação - Universidade Federal de Pernambuco; Administrador - Universidade de Pernambuco - FCAP/UPE; Mestre em Planificación y Gestion Organizacional - Universidad Autonoma de Madrid / Espanha; Mestre em Dirección y Organización de Hospitales y Servicios de Salud - Universidad Politécnica de Valencia / Espanha; Especialista em Marketing - FCAP/UPE; Consultor em Sistemas Organizacionais, desde 1984; Professor e Diretor Acadêmico da Faculdade Metropolitana da Grande Recife.

E-mail: arandi.campelo@globo.com

2 Aluno de Administração / Faculdade Metropolitana da Grande Recife.

E-mail: erykmarcelo-portela@hotmail.com

3 Aluno de Administração / Faculdade Metropolitana da Grande Recife.

E-mail: mirellymendess@gmail.com

4 Aluno de Administração / Faculdade Metropolitana da Grande Recife.

E-mail: robsonadm28souza@gmail.com 
students from the administration course at Faculdade Metropolitana da Grande Recife FMGR. The study was centered on demonstrating the digital marketing strategies that are practiced by the company, from the perspective of its students, in the online environment that works as the ideal way to reach the goals of each brand, each institution, existing in different social networks. The bibliographic investigation was developed from book studies, website searches and had, as main source, the conceptual bases of Kotler $(2010 ; 2017)$, among other authors. The field research, carried out in 2020, with the application of questionnaires, using the Google Forms tool, revealed that any strategy or action aimed at attracting and retaining customers must precede well-defined marketing objectives and their process of creation and placement in Social Media must necessarily be related to what is expected to be achieved in line with the purposes of the institution under study.

Keywords: Digital marketing. Attracting and retaining customers. Social networks.

\section{INTRODUÇÃO}

$\mathrm{O}$ artigo aborda fatores do marketing digital, imprescindíveis às organizações, como meio de lidar com as dificuldades e a falta de informação que, além de comprometer a comunicação com seus consumidores, dificultam a captação de novos clientes e, principalmente, sua fidelização.

$\mathrm{Na}$ sociedade moderna a competitividade interfere de modo significativo no contexto das organizações, uma vez que há uma quantidade enorme de empresas, além de uma grande variedade de produtos e serviços oferecidos. Neste cenário, o conhecimento e o capital intelectual são bens bastante valorizados pelas instituições. Portanto, as empresas estão usando estratégias para adquirir melhor conhecimento acerca do ambiente interno/externo e de seus concorrentes, visando oferecer produtos e serviços mais atrativos.

\section{REFERENCIAL TEÓRICO}

Como referencial teórico baseamos nossa pesquisa em temas focados na força do marketing digital, na captação e fidelização de clientes, que subsidiaram a construção do trabalho de campo, realizada com alunos do curso de administração da FMGR, com o propósito de apresentarem sua visão sobre as estratégias de marketing digital aplicadas pela instituição investigada, pois "na internet, a interação é uma vida de mão dupla. Os clientes têm mais voz e podem multiplicar sua fala rapidamente, não são apenas receptores, são também emissores de mensagens". (FARIAS et al, 2015, p. 19).

A investigação bibliográfica foi desenvolvida a partir de estudos de livros, artigos e pesquisas em sites e teve, como principal fonte, as bases conceituais de Kotler et al (2010; 2017), dentre outros autores como Farias et al (2015; 2016) e Lima (2012). 


\section{Marketing digital}

Antes de demonstrar a finalidade e aplicabilidade das redes sociais nas relações de vendas, é importante compreender o que vem a ser o marketing digital. Consiste em ações de comunicação que as organizações podem utilizar, por meio da internet, da telefonia celular e outros meios digitais, com o propósito de divulgar e comercializar seus produtos e serviços, conquistando novos clientes e melhorando sua rede de relacionamentos.

O marketing digital é uma estratégia de vendas, no mundo das redes sociais, proporcionando relações com clientes, através da comunicação, que pode proporcionar amplas oportunidades de negócios, lançamento de novos produtos no mercado etc. Com a evolução da tecnologia essas possibilidades são, cada vez mais, ampliadas, pois a onda tecnológica da atualidade permite a conectividade e a interatividade entre indivíduos e grupos; indivíduos e organizações; indivíduos, organizações e mercado. (KOTLER et al, 2010, p.7).

Além de impulsionar produtos relacionados aos clientes, o marketing digital atende às necessidades dos mesmos de maneira rápida e confortável, ganhando tempo no mercado e melhorando o desempenho das vendas. É fato que a sociedade, de um modo geral, está vinculada e dependente da internet e das redes sociais, por isso o marketing digital facilita o alcance e a visualização de marcas e produtos, algo extremamente desejável e necessário a qualquer segmento organizacional.

Outro aspecto fundamental é a oportunidade que se tem em conhecer e segmentar o mercado consumidor, pois o "marketing precisa segmentar o mercado e desenvolver um produto superior para um mercado-alvo especifico. A regra de ouro, segundo a qual cliente é rei, funciona bem para a maior parte das empresas." (KOTLER et al, 2010, p. 4). No mercado competitivo o marketing digital está diretamente relacionado a ganho de espaço nos negócios, proporcionando a apresentação do melhor produto, preço, a melhor promoção, bem como a forma mais eficiente de levar o produto ao consumidor, gerando sensação de segurança e satisfação para quem compra e para quem vende.

Com boas informações, pode-se chegar ao público alvo com maior rapidez e eficiência através das redes sociais, facilitando a captação, fidelização e motivação de clientes.

Atualmente existem diversas técnicas, ferramentas e meios que facilitam a atração da presença online das pessoas, para quem divulga produtos e serviços através de redes sociais, do próprio portal oficial da organização. No entanto, para que isso seja realidade, é necessária a presença de um profissional de marketing e um profissional de redes sociais que unam esforços não apenas de curto prazo, imediatista, mas, principalmente, de longo prazo, ou seja, 
“O futuro do marketing será moldado em parte pelos eventos atuais e, em parte, pelas forças no longo prazo.” (KOTLER et al, 2010, p. 33).

\section{Relacionamento com clientes}

Para ter um bom relacionamento com clientes é preciso compreender a necessidade de construir e gerenciar relacionamentos duradouros com os mesmos, que pode resultar em lucratividade a curto, médio e longo prazos. Há várias ferramentas capazes de mensurar a lucratividade, oriunda das relações com clientes como, por exemplo, o Customer Equity, que consiste em capturar valores de todos os clientes, ao longo do tempo, a partir de produtos que possam representar valores de qualidade, reconhecidos pelos clientes. Nessa perspectiva, é preciso repensar seus produtos e serviços e em que neles pode-se agregar valor. Desse modo, poderá captar novos clientes, atraídos por essas transformações, pois as organizações devem focar na "[...] quantidade de pessoas que jamais teriam acesso a um determinado produto e que, a partir dessa transformação, podem conhecê-lo e comprá-lo.” (FARIAS et al, 2015, p. 241).

Com foco no Customer Equity, é possível ter uma margem de lucratividade e fidelidade de clientes e o marketing digital, nesse sentido, revela-se como poderosa ferramenta para que essas ações cheguem aos ouvidos de seus clientes.

\section{Como lidar com a concorrência nas redes sociais}

A cada dia a concorrência se torna mais acirrada e competitiva, proporcionando, por um lado, elevado grau de preocupação às organizações, mas por outro lado, abrindo um vasto e amplo campo de oportunidades de melhoria dos produtos e serviços ofertados no mercado. Para que isso ocorra é necessário que as estratégias sejam cada vez mais inovadoras, de modo que possam ser financeiramente viáveis, algo que o marketing digital pode proporcionar, a partir das oportunidades geradas através das redes sociais. Trata-se de investir para atrair a atenção do mercado, do cliente, pois "[...] a percepção do cliente a respeito da empresa, que gera um lucro não contábil significativo, precede o impacto financeiro.” E tal impacto, obviamente, é impulsionado pela atração e fidelização de novos clientes. (FARIAS et al, 2015, p. 247).

As redes sociais dão muitas oportunidades de multiplicar vendas e ter autoconhecimento de sua marca, como os canais do Youtube, Facebook, Instagram, Linkedin, blogs, entre outros, tornando as organizações mais preparadas para o enfrentamento com seus concorrentes. Um planejamento bem estruturado do marketing digital veiculado nas redes 
sociais pode transformar seus clientes em potenciais vendedores a custo zero, uma vez que "o papel dos consumidores não está limitado a promover as marcas; estende-se também a vendêlas." (KOTLER et al, 2010, p. 109).

\section{Captação e fidelização de clientes}

A fidelização de clientes é uma tarefa muito difícil para as organizações, independentemente se ela é de bens e/ou serviços. O diferencial está na sua capacidade de agir de forma proativa junto aos seus clientes. Atitudes simples e verdadeiramente focadas nas necessidades atuais e potenciais de clientes podem fazer muita diferença nas ações de captação e fidelização. Nesse sentido, é fundamental conhecer seu público e identificar suas necessidades e desejos em relação ao que é ofertado no mercado.

Para que isso aconteça é necessário estruturar cadastros com dados dos clientes que facilitem sua identificação - não só dados de documentação e identificação, mas dados adicionais como hobbies, práticas de esportes, clubes de futebol etc.

De acordo com Lima (2012), a organização não dever olhar para o produto a ser ofertado ao cliente, mas para as necessidades do cliente, de modo a oferecer soluções, preços, e uma boa relação e não, simplesmente, um produto a ser comprado e consumido. Nesse sentido cabe afirmar que:

É evidente que não se deve fazer tudo o que o cliente quer sem que haja uma margem de contribuição viável na negociação. Mas desconsiderar suas necessidades e impor-lhe produtos-padrão parece não ser mais suficiente atualmente. (LIMA, 2012, p. 110).

Com o advento da internet e das mídias sociais, as organizações criam estratégias para divulgação no mundo digital, cada dia mais utilizadas, impulsionando as atividades do ecommerce, ou seja, "Hoje vivemos em um mundo totalmente novo. A estrutura de poder está passando por mudanças drásticas. A internet, que trouxe conectividade e transparência às nossas vidas, tem sido em grande parte responsável por essas transformações." (KOTLER et al, 2017, p. 17).

A utilização de estratégias alicerçadas no marketing digital melhora consideravelmente a comunicação entre organizações e clientes, pois, atualmente, é possível se fazer quase tudo sem ter que sair de casa. Criar uma relação com os clientes terá sempre como consequências positivas a atração e fidelização dos mesmos. Segundo Gummesson (2010), trata-se de uma função organizacional, sendo "um conjunto de processo para a criação, comunicação e entrega de valores aos clientes, bem como para a administração de relacionamentos com os 
clientes de modo que beneficie a organização e seus stakeholders.” (GUMMESSON, 2010, p. 30). Interagindo com seus clientes, através das redes sociais, as organizações elevam sua visibilidade, atraindo e fidelizando clientes potenciais.

\section{Inteligência competitiva do marketing digital}

A inteligência competitiva, proporcionada pelo marketing digital, é um modelo que capta e organiza muitas informações relevantes sobre os concorrentes; identifica comportamentos dos clientes; e facilita a compreensão de como o mercado está funcionando, as tendências e cenários para o futuro, melhorando os processos de tomada de decisões a curto, médio e longo prazos.

As organizações precisam conhecer, cada vez mais, quem são seus clientes, seus hábitos de consumo, hobbies etc. O uso desses dados, facilmente rastreados pela inteligência competitiva, pode agregar valor aos produtos e serviços ofertados pelas organizações, ampliando sua capacidade competitiva.

Em um cenário de alta competitividade que permeia a realidade contemporânea, a inteligência competitiva proporciona inúmeras ferramentas que possibilitam a coleta de dados, transformando-os em informações úteis. As redes sociais, por sua vez, tendem a ser um campo cada vez mais crescente nesse sentido. As organizações, aproveitando esse momento, utilizam as redes sociais para montarem suas estratégias competitivas, passando a ser uma das ferramentas mais utilizadas na web. As empresas estão usando-as para conhecer melhor seus clientes e concorrentes. Desta forma, as comunidades virtuais e/ou redes sociais se configuram como importantes fontes e canais de informações que podem auxiliar significativamente na geração do processo de inteligência competitiva organizacional.

\section{A força das redes sociais na captação e fidelização de clientes}

Atualmente existe a necessidade de adaptação à constante evolução da cultura tecnológica e das redes sociais. Nesse contexto, a influência da popularidade, reputação e visibilidade exercida pelas redes sociais criam relacionamentos não só entre as pessoas, mas entre clientes e organizações também. É necessário ter atenção a esse fenômeno que, a cada dia, se inova e renova o mercado do marketing digital. Na realidade, "a serviço da economia de mercado, que domina os meios de comunicação de massa, a informação frequentemente se transformar em publicidade comercial e em propaganda politica.” (GÓMEZ, 2015, p. 18).

O marketing digital não é apenas parte, mas uma das principais partes da comunicação que vem se desenvolvendo e promovendo transformações no modo como as relações entre 
pessoas e organizações estão se estabelecendo. A mídia social, que se utiliza das redes sociais, consiste em um conjunto de aplicações baseadas na internet, construídos sob fortes influências ideológicas, típicas dos diversos grupos sociais que se utilizam desses meios de comunicação global. Logo, é preciso investir em redes sociais, fazer anúncios e propagandas, publicação, criar grupos, investir em pessoas com visibilidade, ligadas à mídia social, pois, não por acaso, "o movimento social é caracterizado pela união de pessoas em torno de um objetivo comum, que compartilham valores políticos e culturais, criando, assim, uma identidade comum ao movimento." (SANTOS, 2018, p. 14).

\section{Gestão do relacionamento com clientes}

$\mathrm{Na}$ era da comunicação, investir na gestão de relacionamento com o cliente é uma das melhores táticas para se diferenciar no mercado. Visando um bom relacionamento com os clientes e suas necessidades, é preciso identificá-los não apenas como clientes, mas como indivíduos, e fazê-los se sentir como parte integrante da organização, caracterizando-os por suas características, valores, peculiaridades e, a partir daí, personalizar a oferta em função do perfil de cada grupo de clientes.

Essa é uma forma bastante eficiente de promover atrativos com versatilidade e visibilidade para os clientes. Tais estratégias devem ser implementadas através de campanhas promocionais e sazonais, através das redes sociais, se configurando como um considerável diferencial na construção e segurança das relações entre organizações e clientes, numa projeção fiel e duradoura, com muita rapidez, o que pode ser plenamente viabilizado através da tecnologia, pois como já afirmava Gómez, “[...] a internet pode estar antecipando uma nova forma de pensar baseada mais nos processos do que nos produtos, na necessidade imperativa de sintetizar a vasta e diversificada morfologia atual da informação." (GÓMEZ, 2015, p. 25).

\section{METODOLOGIA}

O objeto de estudo deste projeto consistiu no marketing digital aplicado ao relacionamento de uma instituição de ensino superior com seus alunos. Como objetivo geral, buscou-se verificar como se dá a comunicação da instituição com os alunos, através de redes sociais como o Instagram, Facebook e Whatsapp. Especificamente, procurou-se:

a) Identificar as principais dificuldades que os alunos têm em se comu nicar com a instituição, através das redes sociais; 
b) Obter sugestões dos alunos para aprimorar a forma de comunicação da instituição com os mesmos, através das redes sociais.

O tipo de instrumento utilizado na pesquisa de campo foi o questionário semiaberto com perguntas objetivas e subjetivas. A amostra foi de 30 estudantes do curso de administração, cujo universo contempla 200 alunos regulamente matriculados no semestre letivo em que ocorreu a pesquisa (2020.1). Os critérios para definição dessa amostra foram:
a) Alunos do curso de Administração;
b) Cursando do $1^{\circ}$ ao $4^{\circ}$ período;
c) Com idade entre 20 a 50 anos;
d) Regularmente matriculados nos turnos da manhã e noite.

\section{DESENVOLVIMENTO DA PESQUISA DE CAMPO}

A pesquisa de campo, que subsidiou este artigo, foi aplicada a alunos do curso de Administração da Faculdade Metropolitana da grande Recife, através do Google Forms. Das doze questões indagadas, oito merecem destaque pela relevância das respostas, ao serem analisadas à luz do referencial teórico.

\section{Gráfico 1 - O que você acha da divulgação de cursos e eventos da Faculdade Metropolitana?}
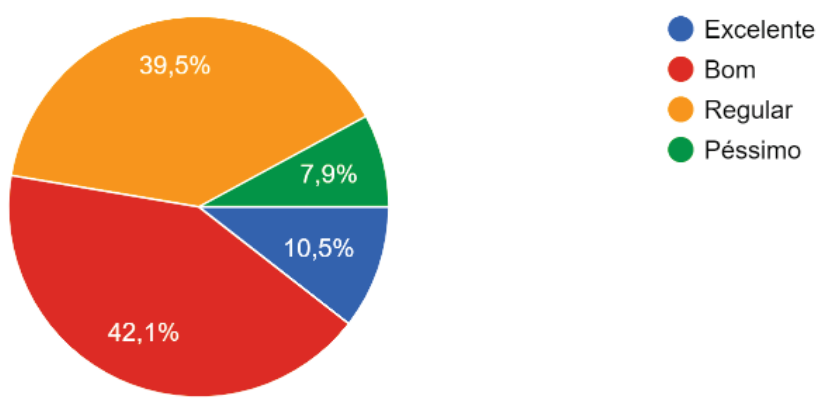

Dentre os participantes da pesquisa, $52,6 \%$ classificaram entre excelente e bom o trabalho de divulgação que o campo investigativo deste artigo vem realizando em termos de divulgação de seus eventos. Uma perspectiva que vai de encontro com a fala de Kotler et al (2010, p. 33) ao afirmar que “o futuro do marketing será moldado em parte pelos eventos atuais e, em parte, pelas forças no longo prazo", algo que é fortemente proporcionado através da divulgação de eventos, nas redes sociais, pela instituição investigada. 
Gráfico 2 - Você acha que a Faculdade deveria investir mais em propagandas nas redes sociais?

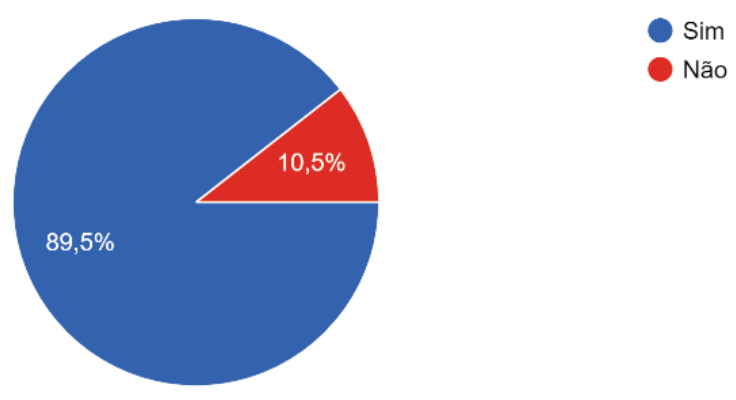

Apesar de mais de 50\% considerarem entre bom e excelente o trabalho de divulgação da FMGR, nessa questão, 89,5\% afirmam que a Faculdade Metropolitana deveria investir mais em propagandas focadas em redes sociais. Uma afirmativa compatível com a visão de Farias (2016), ao afirmar que as estratégias de segmentação de mercado devem, além de seguir a missão e visão das organizações, como dos desdobramentos do seu planejamento estratégico, ser imperativamente disseminados através das redes sociais, que se ajustam e se modernizam constantemente.

Gráfico 3 - Na sua visão, as redes sociais estão trazendo resultado para a Faculdade Metropolitana?

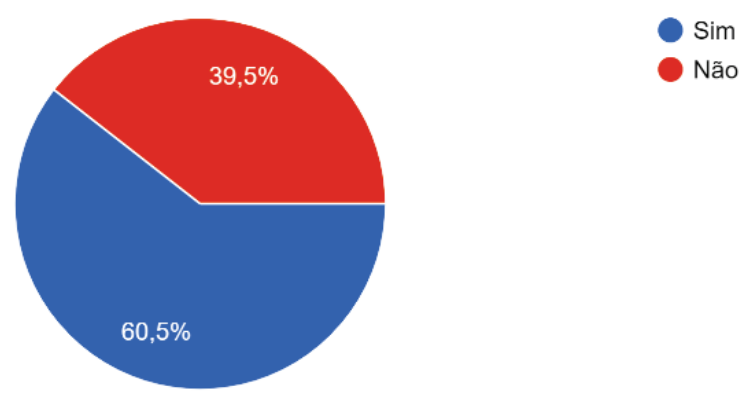

Nessa questão 60,5\% dos alunos de administração da FMGR consideraram as redes sociais como fontes de resultados positivos para a instituição e, num percentual não desprezível, 39,5\% afirmaram que esses resultados não estão ocorrendo via redes sociais. Nessa perspectiva, Kotler et al (2010, p. 109) afirma que "o papel dos consumidores não está limitado a promover as marcas; estende-se também a vendê-las.” Essa venda, no contexto atual de mercado, é fortemente promovida através das redes sociais. 
Gráfico 4 - Como você avalia a comunicação geral da Faculdade com os alunos, através as redes sociais?

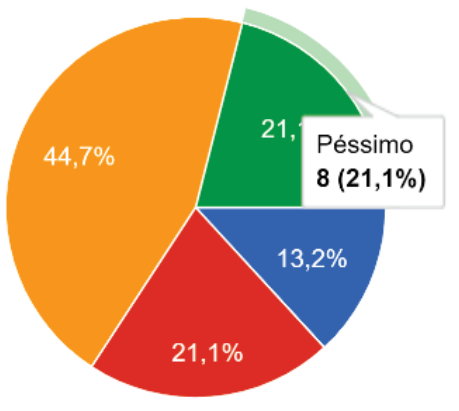

Observamos, de acordo com o gráfico, que $65,8 \%$ classificam de bom a excelente a comunicação que o campo investigativo deste artigo vem realizando junto aos seus alunos, numa comunicação direta pelas redes sociais. Uma perspectiva compatível com a visão de Gómez (2015, p. 25), ao afirmar que "[...] a internet pode estar antecipando uma nova forma de pensar baseada mais nos processos do que nos produtos, na necessidade imperativa de sintetizar a vasta e diversificada morfologia atual da informação.” (GÓMEZ, 2015, p. 25).

Gráfico 5 - Em sua opinião os canais de divulgação e anúncios no Instagram e Facebook sempre lhe mantem informado? Se a alternativa for não, comente.

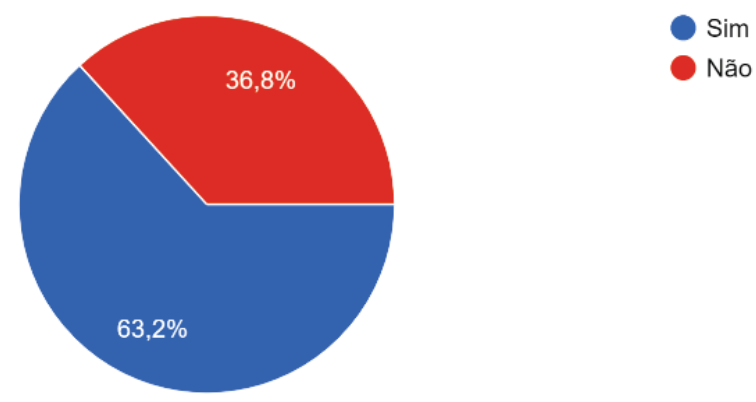

Apenas 36,8\% dos investigados consideram que não estão sendo informados por esses canais de divulgação da Faculdade Metropolitana - Instagram e Facebook. Por outro lado, $63, \%$ afirmaram que sim. Uma perspectiva de realidade bastante positiva e, de certo modo, compatível com as observações de Gummesson (2010), quando destaca a influência que as redes sociais exercem sobre o comportamento de seus usuários, na mesma proporcionalidade em que são, por eles, utilizadas. 
Gráfico 6 - Que benefícios o investimento em marketing digital pode trazer para a Faculdade Metropolitana, na sua concepção?

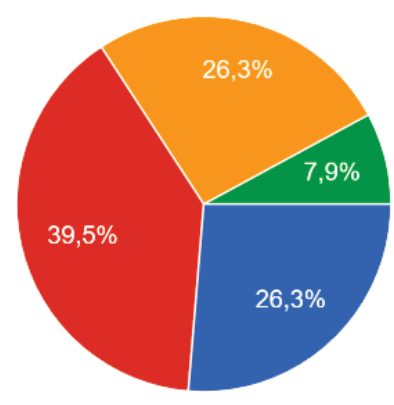

a) Fidelizar alunos;

b) Maior comunicação com alunos;

c) Competir com a concorrência;

d) Uso das redes sociais;

Aqui, 39,5\% dos pesquisados consideram que o maior benefício do marketing digital para a Faculdade Metropolitana é a comunicação com os alunos. Uma perspectiva que vai de encontro com a visão de Farias et al (2015, p. 241) ao afirmar: "pense só nas oportunidades de comunicação, de fidelização e de segmentação. Pense na quantidade de pessoas que jamais teriam acesso a um determinado produto e que, a partir dessa transformação, podem conhecêlo e comprá-lo."

Gráfico 7 - Antes de você entrar na Faculdade você já fez alguma pesquisa nas redes sociais como Instagram ou Facebook sobre cursos oferecidos pela instituição?

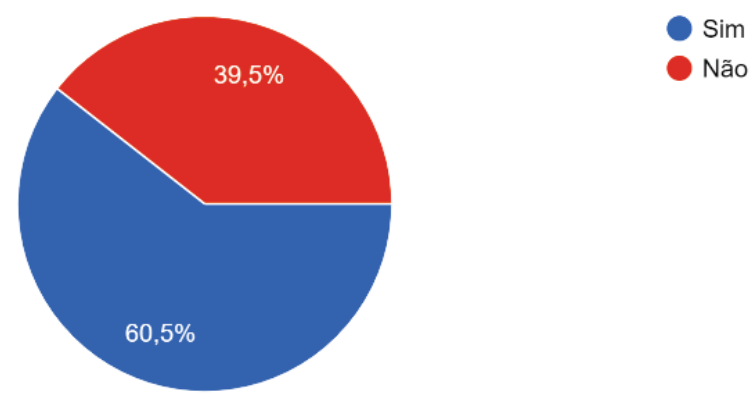

Nessa questão $60,5 \%$ dos entrevistados fizeram alguma pesquisa nas redes sociais sobre cursos oferecidos no mercado. Nesse sentido, afirma Santos (2018, p. 14): “o movimento social é caracterizado pela união de pessoas em torno de um objetivo comum, que compartilham valores políticos e culturais, criando, assim, uma identidade comum ao movimento." 
Gráfico 8 - Você considera importante a Faculdade investir na contratação de um profissional só para se dedicar às ações do marketing digital? Comente sua resposta.

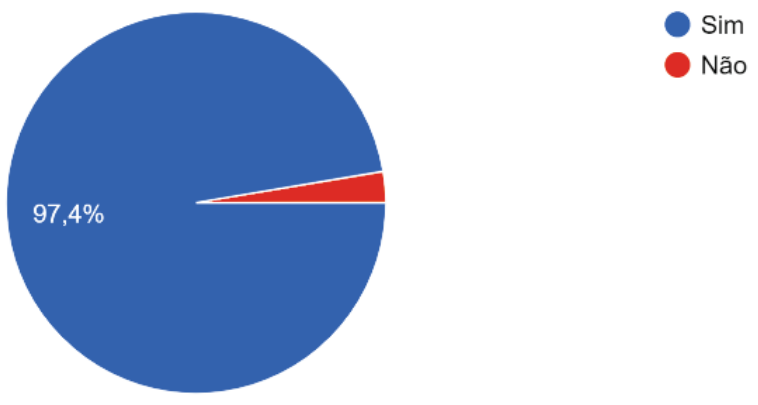

Um expressivo percentual de $97,4 \%$ considera importante a contratação de um profissional especializado na área de marketing digital para a Faculdade Metropolitana. Como bem definiu Kotler et al (2010, p.4): o “[...] marketing precisa segmentar o mercado e desenvolver um produto superior para um mercado-alvo especifico. A regra de ouro segundo a qual 'o cliente é rei' funciona bem para a maior parte das empresas."

\section{CONSIDERAÇÕES FINAIS}

A pesquisa, realizada com alunos do curso de Administração da Faculdade Metropolitana da Grande Recife, durante o primeiro semestre de 2020, revelou que qualquer estratégia ou ação que vise captar e fidelizar clientes deve preceder de objetivos de marketing bem definidos, e seu processo de criação e veiculação nas mídias sociais precisam, necessariamente, estar relacionados com o que se espera alcançar de modo alinhado com os propósitos da instituição em estudo. Outro ponto relevante da pesquisa foi o reconhecimento de que a Faculdade tem se esforçado nas ações do seu marketing digital, mas que esses esforços poderiam ser mais produtivos se fosse contratado um profissional focado nesta atividade, como um digital influencer, por exemplo.

No contexto dos objetivos específicos, merecem destaques, como principais dificuldades de comunicação entre a instituição e seus estudantes, as afirmativas de que a Faculdade não investe adequadamente em propagandas nas redes sociais, de maneira profissionalizada, exatamente pela carência de um profissional especializado nessas ações e que, por isso, muitos $(36,8 \%)$ consideram-se pouco informados pela instituição sobre seus eventos.

No tocante às propostas de melhoria é recomendável que a Faculdade estruture sua área de marketing digital, com a contratação de um digital influencer, além de investir na 
propaganda em redes sociais, de maneira profissionalizada, uma percepção também diagnosticada junto aos alunos que participaram da pesquisa.

\section{REFERÊNCIAS}

FARIAS, Claudio; DUSCHITZ, Caroline; CARVALHO, Gustavo Meneghetti de. Marketing aplicado. Porto Alegre: Bookman, 2015.

. Estratégia de marketing. Porto Alegre: SAGAH, 2016.

GÓMEZ, Á. P. Educação na era digital: a escola educativa. Porto Alegre: Penso, 2015.

GUMMESSON, Evert. Marketing de relacionamento total. 3. ed. Porto Alegre: Bookman, 2010 .

KOTLER, P.; KARTAJAYA, H.; SETIWAN, I. Marketing 4.0: do tradicional ao digital. Rio de Janeiro: Sextante, 2017.

KOTLER, Philip et al. Marketing 3.0: as forças que estão definindo o novo marketing centrado no ser humano. Rio de Janeiro: Elsevier, 2010.

LIMA, A. Como conquistar, fidelizar e recuperar clientes: gestão de relacionamento. São Paulo: Atlas, 2012.

PÉREZ GÓMEZ, Ángel I. Educação na era digital: a escola educativa. Porto Alegre: Penso, 2015.

SANTOS, Ana Paula Fliegner dos et al. Movimentos sociais e mobilização social. Porto Alegre: SAGAH, 2018.

\section{Apêndice A - Modelo de questionário para a pesquisa de campo}

Este instrumento tem por finalidade coletar dados sobre o marketing digital na captação e fidelização de clientes e a realidade dos alunos de administração da Faculdade Metropolitana da Grande Recife, cujo objetivo consiste em verificar a melhor forma de comunicação da instituição com os alunos.

1. O que você acha da divulgação de cursos e eventos da Faculdade Metropolitana?
a) Excelente
b) Bom
c) Regular
d) Péssimo

2. Você acha que a faculdade deveria investir mais em divulgação nas redes sociais? a) $\mathrm{Sim}$ 


\section{b) Não}

3. $\mathrm{Na}$ sua visão, as redes sociais estão trazendo resultados para a Faculdade Metropolitana?
a) $\mathrm{Sim}$
b) Não

4. Como você avalia a comunicação geral da faculdade com os alunos, através das redes sociais?
a) Excelente
b) Bom
c) Regular
d) Péssimo

5. Em sua opinião nos canais de divulgação e anúncios no Instagram e Facebook sempre lhe mantem informado? Se a alternativa for não, comente.
a) $\mathrm{Sim}$
b) Não

6. Qual a sua avaliação sobre os avisos de estágios para os alunos dentro da instituição?
a) Excelente
b) Bom
c) Regular
d) Péssimo

7. Que benefícios o investimento em Marketing Digital pode trazer para a Faculdade, na sua concepção?
a) Fidelizar alunos
b) Maior comunicação com alunos
c) Competir com a concorrência
d) Uso das redes sociais
e) Outro (especifique):

8. Antes de você entrar na faculdade você já fez alguma pesquisa nas redes sociais como Instagram ou Facebook sobre os cursos oferecido pela Metropolitana?
a) $\mathrm{Sim}$
b) Não

9. Você indicaria um amigo para estudar na faculdade? Por qual motivo? Comente sua resposta.
a) $\mathrm{Sim}$
b) Não

10. Como você avalia o desconto oferecido pela faculdade em relação à indicação de amigos? Comente sua resposta.
a) Excelente
b) Bom
c) Regular 
d) Péssimo

11. Você considera importante a faculdade investir na contratação de um profissional só para se dedicar às ações do marketing digital? Comente sua resposta.
a) $\operatorname{Sim}$
b) Não

12. Em uma escala de 0 a 10 quanto você atribui ao marketing digital da Faculdade? E por quê? 


\title{
METODOLOGIAS ATIVAS NA EDUCAÇÃO DE JOVENS E ADULTOS : UM ESTUDO BIBLIOGRÁFICO
}

\author{
https://dx.doi.org/10.48097/2674-8673.2021n5p15
}

\author{
Joseli Soares da Silva ${ }^{1}$ \\ Vitória de Oliveira Silva ${ }^{2}$ \\ Fabiana Maria da Silva ${ }^{3}$
}

\begin{abstract}
RESUMO
O presente trabalho teve como objetivo principal analisar a relação entre metodologias ativas e o ensino e a aprendizagem de jovens e adultos. Esta pesquisa, de natureza qualitativa e do tipo exploratória, foi realizada a partir de estudo bibliográfico. O processo histórico da educação de jovens e adultos, desde sua constituição, e apesar de ser estruturado por lei, carece de estruturas e práticas pedagógicas mais específicas. Esse contexto coloca a importância das metodologias ativas como uma possibilidade de organização de aulas mais atraentes para os estudantes dessa modalidade e por romperem com um modelo tradicional de educação. As metodologias ativas são estratégias pedagógicas que colocam os estudantes como centro do processo educacional a partir de práticas inovadoras, capazes de promover a construção do conhecimento de maneira autônoma pelos estudantes. O presente estudo revelou que as metodologias ativas são extremamente pertinentes para os estudantes da EJA.
\end{abstract}

Palavras-chave: Ensino e Aprendizagem. Metodologias Ativas. Educação de Jovens e Adultos.

Data de submissão: $12 / 02 / 2021$

Data de aprovação: 26/03/2021

\begin{abstract}
The main objective of this work was to analyze the relationship between active methodologies and the teaching and learning of young people and adults. The present research, of qualitative nature and of the exploratory type, was carried out from a bibliographic study. The historical process of youth and adult education, since its constitution and despite being structured by law, lacks more specific pedagogical structures and practices. This context places the importance of active methodologies as a possibility of organizing more attractive classes for students of this modality and for breaking with a traditional model of education. Active methodologies are pedagogical strategies that place students at the center of the educational process based on innovative practices, capable of promoting the construction of knowledge autonomously by students. The present study revealed that the active methodologies are extremely relevant for EJA students.
\end{abstract}

Keywords: Teaching and Learning Process. Active Methodologies. Youth \& Adult education.

\footnotetext{
${ }^{1}$ Discente do Curso de Licenciatura em Pedagogia da Faculdade Metropolitana da Grande Recife.

E-mail: joselysol@hotmail.com

${ }^{2}$ Discente do Curso de Licenciatura em Pedagogia da Faculdade Metropolitana da Grande Recife. E-mail:

${ }^{3}$ Docente orientadora do Curso de Pedagogia da Faculdade Metropolitana da Grande Recife.

E-mail: fabiana.silva1@gmail.com
} 


\section{INTRODUÇÃO}

Esse artigo se propõe a estudar as metodologias ativas no contexto da Educação de Jovens e Adultos (EJA). Esta modalidade demanda estratégias de ensino diferenciadas, que considerem os educandos integralmente em seus contextos sociais. O desenrolar histórico da EJA nos mostra a necessidade de refletir sobre estratégias educacionais que ajudem os jovens e adultos no desenvolvimento de seus processos educacionais.

O debate sobre a EJA relaciona alguns fatores que fazem com que as pessoas não concluam a educação básica na idade certa. Fatores de ordem social e econômica são os mais citados, como por exemplo, a necessidade de trabalhar, as dificuldades de chegar até as escolas (realidade de muitos municípios brasileiros), e no caso das mulheres ainda tem a questão da gravidez na adolescência que acaba em muitos casos sendo um fator a mais para que as jovens não continuem seus estudos.

Quando essas pessoas decidem retomar seus estudos, muitas vezes se deparam com práticas infantilizadas que pouco as estimulam a dar continuidade aos estudos. É quando encontramos a questão da evasão dos estudantes e muitas vezes isso ocorre porque os alunos não encontram sentido nos conteúdos que lhes são apresentados. É necessário que se busque métodos inovadores que consigam trazer e manter esses alunos numa aprendizagem prazerosa. Pensando nessas dificuldades trazemos nesse de bate as metodologias ativas para o processo de aprendizagem da EJA.

O interesse nesse tema foi por conta de algumas pesquisas feitas em que foi possível observar uma grande evasão dos alunos nessa modalidade e isso nos fez buscar algo diferente e que incentivasse esses alunos a lutar por algo melhor, para que eles não viessem a sair das escolas.

A importância dessa pesquisa é trazer algo inovador que possa ajudar no processo de alfabetização de jovens e adultos, ajudando o docente a explorar as experiências dos alunos como ponto de partida para a construção do conhecimento.

\section{FUNDAMENTAÇÃO TEÓRICA}

Para compreender melhor nossa temática se faz necessário um breve resgate da história da educação de jovens e adultos no Brasil. A esse respeito, as pesquisas mostram que os primeiros anos da Educação de Jovens e Adultos no Brasil são influenciados pelo pensamento educacional colonial brasileiro, marcado pelo caráter restrito e limitado. 


\section{Desenvolvimento histórico da Educação de Jovens e Adultos}

A origem da EJA está demarcada basicamente por dois aspectos principais. O primeiro deles consiste na necessidade de jovens e adultos aprenderem a ler para exercer o seu direito de voto e o segundo aspecto está ligado à necessidade de atendimento mínimo às necessidades das elites brasileiras da década de 30, período de intensa industrialização, e por isso o interesse em formar a mão de obra minimamente "letrada". A EJA não surgiu com a perspectiva de promover o desenvolvimento dos sujeitos, mas sim a partir das necessidades ideológicas e materiais de determinada classe social brasileira. (XAVIER, 2019).

A partir da década de 1940 houve a fixação da Campanha da Educação de Adolescentes e Adultos (CEAA) que consistiu na primeira iniciativa pública de atendimento específico para esse segmento da educação. Mais precisamente em 1947, por emergência de alguns movimentos educacionais, essa campanha considerava a educação capaz de proporcionar a cada indivíduo, segundo suas capacidades, ferramentas fundamentais de domínio e acesso da cultura para melhor desenvolvimento. O propósito era promover educação à população analfabeta, tanto nas cidades quanto nas zonas rurais, para estimular o desenvolvimento econômico. (XAVIER, 2019).

Nessa perspectiva a educação popular, mais especificamente a alfabetização, ganha importância. É nesse contexto que se registra a criação de algumas iniciativas, cujo objetivo era transformar a realidade social das pessoas, como por exemplo: Movimento de Cultura Popular (MCP) de Pernambuco; em Natal, a campanha "de pé no chão também se aprende a ler"; e os Movimentos de Educação de Base (MEB/Centros Populares de Cultura-CPC's) que eram ligados à Igreja Católica.

No contexto dessas iniciativas destaca-se a política de educação do governo de João Goulart, que tinha como organizador o educador Paulo Freire, através do Plano Nacional de Alfabetização de Adultos (PNAA). Na década de 1960, Freire era o responsável pelo desenvolvimento do Programa Nacional de Alfabetização de Adultos (PNAA). Freire foi um grande influenciador das práticas públicas das ações educacionais voltadas para os jovens e adultos. Essa proposta favoreceu a inclusão econômica, social e política desses indivíduos. Assim, o ano de 1960 se torna um marco histórico para a educação desses jovens e adultos.

A Educação de Jovens e Adultos no Brasil veio, ao longo de décadas, ganhando alguma atenção das políticas educacionais. Atualmente, as Diretrizes Curriculares Nacionais abrangem os processos formativos da Educação de Jovens e Adultos como uma das modalidades da Educação Básica, nos termos da LDBN 9394/96. 


\section{Paulo Freire e as práticas pedagógicas na EJA}

No Brasil, pensar em educação de jovens e adultos é pensar em Paulo Freire. A educação que ele propôs estava voltada para a conscientização de vencer primeiro o analfabetismo político para que eles pudessem ler o mundo em sua volta, a partir das suas experiências, de suas culturas, e também de suas histórias.

Paulo Freire deixou contribuições valiosas para o processo de ensino-aprendizagem da Educação de Jovens e Adultos. Uma das contribuições mais importantes é retirar do professor o papel de detentor do saber e transferir para o aluno o papel de construtor e modificador de seus conhecimentos. Paulo Freire vivenciou a Educação de Jovens e Adultos de forma especial, pois não foi somente professor dessa modalidade de ensino, mas também um dos alunos integrantes desse tipo de educação. Essas experiências lhe permitiram analisar os tipos de métodos utilizados para esse público, a partir da sua própria experiência.

O método de ensino proposto por Paulo Freire (2004) trabalha em cima da cultura dos educandos. O saber ler e escrever está diretamente ligado à realidade cultural dos alunos. Se a aprendizagem se desse de forma distanciada da realidade de cada um deles, não faria sentido algum dominar a leitura e a escrita se não pudessem utilizá-la para fazer a leitura do seu mundo.

O que Paulo Freire (2005) mais defendia em suas teorias era a importância de resgatar a autoconfiança do educando. Sem acreditar em si mesmo e em sua capacidade, o educando não tem como libertar-se de sua condição social. A influência de Paulo Freire na modalidade da Educação de Jovens e Adultos é extremamente rica e positiva, devido à metodologia criada por ele, a qual permite a ligação do educando com o mundo em que vive, sem causar no aluno a sensação de que se encontra fora dele.

Encontramos em Freire uma grande defesa para as metodologias ativas, com sua afirmação de que na educação de adulto o que impulsiona a aprendizagem é a superação de desafios a partir da resolução de problemas e da construção do conhecimento novo a partir de conhecimentos e experiências de cada indivíduo. Dessa forma, a educação para Paulo Freire é promover a autoconfiança e autonomia na ação educativa. É nesse ponto que encontramos total relação com as metodologias ativas, pois essas estratégias buscam colocar o aluno no centro de sua própria aprendizagem e criar sua própria autonomia e autoconfiança.

\section{Explicando Metodologias Ativas}

As metodologias ativas surgiram como alternativa para a superação de uma tradição 
de aprendizagem passiva, uma vez que a apresentação oral dos conteúdos, por parte do professor, se constituía como única estratégia didática.

O conceito de metodologia ativa carrega as ideias de John Dewey sobre aluno ativo e construções do conhecimento em situações que superam a tradicional aula expositiva, cuja finalidade é a reprodução e a memorização de conteúdos de ensino. Dewey defende que os conteúdos ensinados em sala de aula são assimilados de forma mais fácil quando são associadas às tarefas realizadas pelos alunos. (PEREIRA et al., 2009).

Como explicam Pereira et al (2009), Dewey sempre defendeu a união da teoria e da prática. Sua contribuição para os processos educacionais dos adultos está justamente no sentido de valorizar a capacidade de pensamento e estimular o aluno adulto a pensar, principalmente em discussões coletivas, quando o conhecimento flui mais facilmente e assim é construído.

Um dos defensores das metodologias ativas aqui no Brasil foi Paulo Freire. O autor acredita que o sucesso na implementação das metodologias ativas vai muito além da sala de aula e requer um esforço global, além de um trabalho amplo que precisa abranger os alunos, professores, gestores e até a família.

As metodologias ativas são amplamente discutidas atualmente em detrimento do novo modelo de sociedade, que formata um novo modelo de estudantes, demandando uma nova configuração da educação e seus métodos. A sociedade está completamente influenciada pelo avanço tecnológico, que tem alterado muito a forma como as pessoas se relacionam, se comunicam e, sobretudo, como aprendem. O conhecimento não é mais exclusividade dos livros e do professor. Graças à tecnologia, as pessoas podem acessar incontáveis tipos de instruções, informações e conhecimentos pela internet. O saber não está mais centrado nas instituições formais de ensino.

Considerando esse cenário, entra em pauta a necessidade das escolas reformularem seus métodos de ensino para atender essa nova lógica de aprendizagem, esse novo perfil de estudantes. As metodologias ativas entram nesse debate, sobretudo, quando nos referimos a sujeitos que já construíram suas personalidades. Esses sujeitos já trazem suas histórias de vida, visões de mundo, construções políticas e sociais. As metodologias ativas funcionam como uma oportunidade de desenvolver aprendizagens, partindo dessas especificidades, de modo que esses estudantes sejam colocados como centro do processo, e sujeitos autônomos na construção do conhecimento.

As metodologias ativas são pertinentes no contexto da EJA porque consistem em uma nova concepção educacional em que os alunos são postos como os protagonistas ou principais 
agentes de seu aprendizado. Elas estimulam a crítica, enquanto os professores incentivam a reflexão.

Berbel (2011) discorre sobre o aspecto da motivação dos estudantes, extremamente importante no contexto da EJA. Para esse autor, a utilização de metodologias ativas favorece a motivação autônoma do aluno, extraindo o potencial do mesmo, despertando curiosidade para descobrir novos conceitos, inserindo o conhecimento teórico, possibilitando uma perspectiva própria e diferente do professor.

Dessa maneira, as metodologias ativas de ensino e aprendizagem podem constituir um caminho para a construção de uma maior participação do aluno, fazendo dele o principal agente da sua formação. Nessa perspectiva, percebemos as metodologias ativas como sendo um conjunto de atividades organizadas, que conta com a intenção educativa, em que os estudantes atuam como agentes ativos no processo de aprendizagem, através de estratégias pedagógicas que estimulam a produção de conhecimento.

As metodologias ativas são, portanto, interessantes para a modalidade EJA porque trazem grandes benefícios: adquirir maior autonomia, desenvolver a confiança, passar a enxergar o aprendizado como algo tranquilo, tornar-se apto a resolver problemas, tornar-se mais qualificado e valorizado, além de ser o protagonista do seu aprendizado. Para a instituição de ensino os benefícios se mostram principalmente pela maior satisfação dos alunos com o ambiente da sala de aula, melhor percepção dos alunos com a instituição, aumento do reconhecimento no mercado, além do aumento da atração, captação e retenção de alunos.

A aplicação de metodologias ativas de aprendizagem tem um papel importante para a educação de jovens e adultos, especialmente no Brasil, onde o setor necessita de transformações. Por isso, é preciso investir não somente em bons conteúdos, mas se faz necessário ter consciência de que aprimorar os procedimentos usados para educar é algo extremamente relevante.

A partir desses conceitos é possível compreender que a utilização das metodologias ativas nos processos de educação dos jovens e adultos é capaz de proporcionar aprendizagens significativas, justamente por, como já foi dito, colocar os indivíduos como sujeitos autônomos de seus processos de construção do conhecimento.

Nesse contexto, situamos o conceito de aprendizagens significativas como consequência da utilização de metodologias ativas. Para David Paul Ausubel (1918-2008), a aprendizagem significativa é elemento essencial ao processo de aquisição do conhecimento do aluno, fundamental para o novo papel do professor e a função social da escola. (MOREIRA, 
1982).

Segundo Moreira (1982), Ausubel elaborou a teoria da aprendizagem significativa e a definiu como o processo através do qual uma nova informação relaciona-se com um aspecto relevante da estrutura de conhecimento do indivíduo. Em linhas gerais, a aprendizagem significativa acontece quando o conhecimento novo se relaciona com a estrutura cognitiva do sujeito, com o que ele já sabe ou já construiu ao longo de suas experiências. O gráfico abaixo ilustra bem essa relação entre as metodologias ativas e as aprendizagens significativas:

Figura 1 - Metodologias ativas e aprendizagens significativas

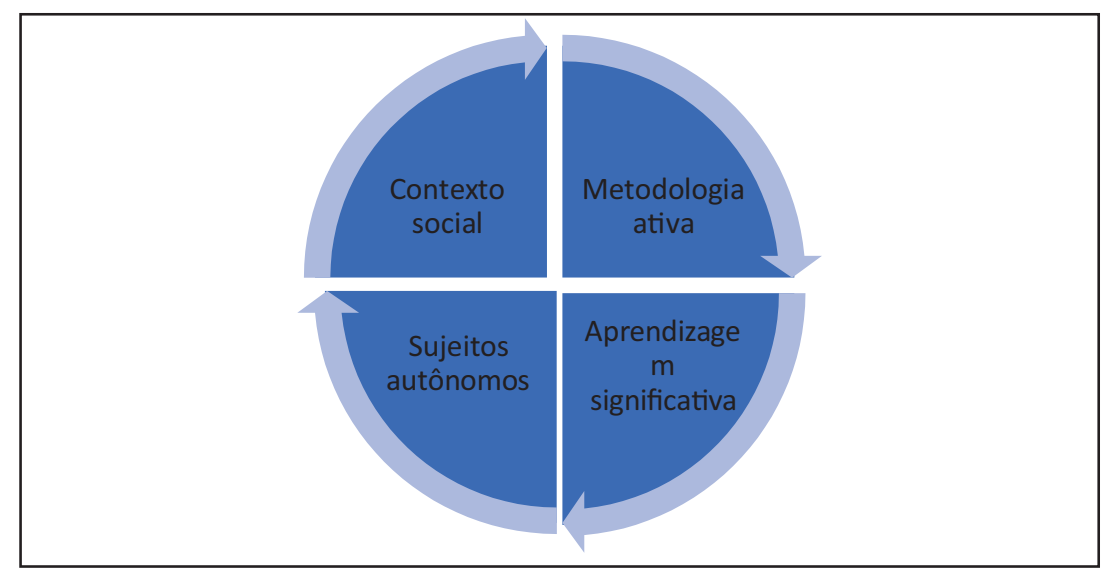

Fonte: as autoras

Assim, as metodologias ativas aplicadas no contexto da EJA são pertinentes por tudo que já foi discutido neste tópico, principalmente por proporcionarem aos estudantes desta modalidade aprendizagens significativas, construídas a partir da valorização de seus contextos sociais.

\section{Metodologias ativas que podem contribuir no processo de alfabetização da EJA}

O processo de ensino e aprendizagem de jovens e adultos necessita de estratégias específicas, pois, evidentemente, as formas como os jovens e adultos aprendem são diferentes das formas como as crianças constroem seu conhecimento, pois há muitas implicações e muita complexidade nesse contexto. Os processos de ensino precisam considerar as especificidades subjacentes à educação dos jovens e adultos. Martins (2013) nos chama atenção nesse aspecto quando afirma que

[...] ensinar já não é mais levar o conhecimento para a sala de aula e, sim, 
enriquecer e valorizar os conhecimentos dos estudantes, o que significa adequar as metodologias tradicionais aos conceitos de ANDRAGOGIA que levarão à construção coletiva dos conhecimentos a partir dos referenciais de vida deles, tornando o aprendizado mais agradável e contextualizado. (MARTINS, 2013, p. $145)$.

O aluno adulto busca na educação contínua a sua realização pessoal e profissional, aprendendo muito melhor quando o assunto tem valor de uso imediato. Quando os processos educacionais não são adaptados, por assim dizer, há um favorecimento da evasão, por parte dos estudantes. É necessário que tanto os currículos quanto os professores e metodologias dialoguem com o perfil desses estudantes. Conforme a visão de Pinto (2010):

É evidente que os problemas pedagógicos (a matéria a ensinar, os currículos, os métodos) correspondentes a cada faixa etária são distintos. Por isso a alfabetização do adulto é um processo pedagógico qualitativamente distinto do infantil (a não ser assim, cairíamos no erro da infantilização do adulto). (PINTO, 2010, p. 74).

Considerando as especificidades que o processo de ensino e aprendizagem dos adultos requer, a utilização de metodologias ativas pode proporcionar o pensamento crítico, boa comunicação, colaboração, e resolução de problemas com criatividade.

Destacaremos a seguir, de acordo com os estudos, as metodologias ativas mais apropriadas no processo de alfabetização de jovens e adultos: Aprendizagem Baseada em Problemas (PBL), Flipped Classroom (Sala de aula invertida) e Grupos Operatórios.

O primeiro exemplo de metodologias ativas indicada para o trabalho com a EJA é a Aprendizagem Baseada em Problemas (tradução para Problem Based Learning - PBL) que surgiu como ferramenta metodológica em 1969 na McMaster University Canadá para o estudo de medicina, mas é possível encontrar exemplos de implementação da PBL em todo o sistema educacional.

A Aprendizagem Baseada em Problemas - PBL é um método cuja característica está centrada no uso de problemas vivenciados e contextualizados ao conteúdo para encorajar os alunos a desenvolverem pensamento crítico e habilidades de solução de problemas e adquirirem conhecimento sobre os conceitos essenciais da área em questão. (RIBEIRO; MIZUKAMI, 2004).

A Aprendizagem Baseada em Problema (PBL) tem como propósito tornar o aluno capaz de construir o aprendizado conceitual, procedimental e atitudinal por meio de problemas propostos que o expõe a situações motivadoras e o prepara para o mundo do trabalho. Essa metodologia é bem interessante para a modalidade EJA, pois, enquanto a 
aprendizagem baseada em projetos exige que os alunos coloquem a "mão na massa", a aprendizagem baseada em problemas é focada na parte teórica da resolução de casos.

Para Ribeiro \& Mizukami (2004), o problema na PBL é um fim aberto, ou seja, não comporta uma única solução correta, mas uma (ou mais) melhor solução, dadas as restrições impostas pelo próprio problema ou pelo contexto de aprendizagem em que está inserido, tais como tempo, recursos, etc.

Este método, também conhecido como situação problema, parte de uma tarefa lançada com situações em tempo real em que o professor apresenta uma questão não tão fácil e nem tão difícil. Assim, o aluno obtém a capacidade de solucionar problemas. Essa metodologia leva o aluno a pensar criticamente, solucionar problemas e desenvolver seu trabalho em equipe. Sendo assim, a PBL é um dos métodos que, como pregava Paulo Freire, apresenta o aluno como protagonista do seu aprendizado e o professor como mediador do saber.

A Sala de Aula Invertida (Flipped Classroom) consiste em um método ativo bastante atual que tem por objetivo minimizar as aulas expositivas e ampliar/facilitar as possibilidades de aulas online. Seria muito interessante para a modalidade EJA, pois, nesse modelo, os alunos teriam acesso aos conteúdos de forma virtual, o que otimiza o tempo reservado aos estudos, uma necessidade tão pontual para os estudantes da EJA que muitas vezes precisam combinar estudo e trabalho.

A Sala de Aula Invertida é uma forma de evitar seguir o modelo tradicional expositivo de aula aumentando a participação e a produtividade. Ela faz parte da tendência do ensino híbrido, pois trabalha com a fusão de aulas presenciais e online, a partir das Tecnologias de Informação e Comunicação (TICS). Isso dá aos estudantes a possibilidade de solucionar as dúvidas no momento em que elas surgem, com a ajuda de seus colegas e do professor, promovendo um ambiente colaborativo de aprendizagem.

A abordagem requer que o aluno estude o tema em seu tempo, antes da aula presencial, para que ele seja capaz de acompanhar as discussões e possa alcançar um maior aproveitamento das informações. O método da Sala de Aula Invertida é apresentado como uma proposta de repensar os processos de ensino e aprendizagem no espaço onde ocorrem, objetivando a inserção de metodologias e tecnologias educacionais, no sentido de otimizar as etapas de transmissão e de assimilação dos conhecimentos. (SCHNEIDERS, 2018).

A Sala de Aula Invertida consiste na inversão do modelo tradicional, no qual o professor passa o conteúdo e em seguida, em casa, o aluno tenta resolver os exercícios e identifica suas dúvidas. A intenção é que os estudantes da EJA tenham o primeiro contato com o conteúdo antes de chegarem à escola, para então serem auxiliados pelo educador em 
relação às dúvidas e à resolução de questões.

Outro exemplo de metodologia ativa defendida para a EJA é a metodologia baseada em Grupos Operativos. Ela coloca em evidência a possibilidade de uma nova elaboração de conhecimento, de integração e de questionamentos acerca de si e dos outros. A aprendizagem é um processo contínuo em que comunicação e interação são indissociáveis, na medida em que aprendemos a partir da relação com os outros. (MORAN; BACICH, 2018).

Em outras palavras, metodologias baseadas em Grupos Operatórios ajudam o aluno a interagir com os colegas, compartilhando conhecimento e trabalhando com um pensamento crítico, pois a constituição do sujeito é marcada por uma contradição interna, onde ele precisa, para satisfazer as suas necessidades, entrar em contato com o outro, vincular-se a ele e interagir com o mundo.

Essa metodologia é indicada para a EJA porque pressupõe a possibilidade de ser uma forma de aprendizado centrada no aluno, que é uma prerrogativa da aprendizagem ativa, ainda com o viés de ser uma estratégia metodológica que envolve o trabalho em grupo na busca da formação crítica.

Alguns autores falam que o grupo é o contexto onde se pode reconstruir e criar significados, vivenciar questões através da troca de informações, do insight, da identificação e outros processos. O grupo funciona como um campo de referências cognitivas e afetivas, em que o sujeito se integra e se reconhece, podendo tanto bloquear quanto estimular processos criativos e críticos.

No contexto desses exemplos de metodologias ativas para o trabalho na EJA, é importante pensar o fazer pedagógico nessa perspectiva, e isso requer também destacar a necessidade dos processos de formação de professores contemplarem também as necessidades desta modalidade. Não basta dispor de uma série de estratégias específicas para a EJA, sem que os professores saibam como colocá-las em prática. No entanto, o docente que aplicar as metodologias ativas terá como resultado a promoção do educando reflexivo, autônomo, crítico e com conhecimento baseado em uma metodologia que o torna corresponsável pelo seu próprio conhecimento.

\section{METODOLOGIA}

A presente pesquisa possui natureza qualitativa, que nos parece mais indicada para as pesquisas em educação, já que é baseada no caráter subjetivo, ou seja, seu resultado não mostra números concretos, e sim narrativas, ideias e experiências individuais dos 
participantes.

Optamos por realizar uma pesquisa exploratória, a partir de levantamento bibliográfico como técnica de coleta de dados. Os materiais utilizados nessa pesquisa foram sete livros e cinco artigos científicos pesquisados nas plataformas da Scielo e no Google Acadêmico.

Assim, foi realizado um levantamento bibliográfico desenvolvido com base em material já elaborado acerca da temática de metodologias ativas no processo de ensino e aprendizagem na educação de jovens e adultos, constituído por livros e artigos científicos. A partir dos dados obtidos, realizou-se a análise e interpretação das informações, mesclando-as de maneira a conseguir uma maior compreensão e aprofundamento sobre o tema abordado.

\section{RESULTADOS}

Ao analisar a história da educação de jovens e adultos foi possível descobrir que esta modalidade de ensino é amparada por lei e tem como objetivo atender os indivíduos que não tiveram acesso, por algum motivo, ao ensino regular na idade apropriada. A EJA visa escolarizar e socializar esses alunos, a partir do princípio da igualdade do direito à educação. O desenvolvimento histórico da EJA também revelou que esta modalidade surgiu a partir de interesses ideológicos, no sentido de formar uma classe trabalhadora minimamente letrada, e que pudesse dar conta do desenvolvimento da elite brasileira.

A Educação de Jovens e Adultos teve algumas conquistas ao longo dos anos, e uma delas foi o fato desta modalidade ter sido incluída no Fundo de Manutenção e Desenvolvimento da Educação Básica e de Valorização dos Profissionais da Educação (FUNDEB), em 2007. Esse fato ajudou muito nas questões básicas, como reservas e recursos para a educação de jovens e adultos, por exemplo.

O objetivo dessa modalidade de ensino é permitir que pessoas adultas, que não tiveram a oportunidade de frequentar a escola na idade certa, possam retomar seus estudos e recuperar o tempo perdido. Nas pesquisas realizadas observamos uma carência muito grande nessa modalidade, além de grande evasão nas escolas devido a inúmeros motivos, com destaque para as metodologias aplicadas em sala de aula, que muitas vezes não são pensadas para esse perfil de estudantes.

A pesquisa nos revelou que as metodologias ativas são capazes de suprir essa falta de especificidade que acontece na EJA, uma vez que podem ajudar os alunos a terem mais interesse pelas aulas, saindo da perspectiva tradicional, em que o professor é o protagonista do processo. Com a utilização de metodologias ativas o professor passa a ser o mediador do processo e o aluno passa a ser o protagonista do seu próprio aprendizado, sendo um aluno 
mais crítico e reflexivo.

Com o estudo dos conceitos de metodologias ativas o presente artigo evidenciou que, como o professor tem um papel crucial na formação dos estudantes, o trabalho pedagógico do docente é crucial para que a utilização das metodologias ativas proporcione aprendizagens significativas.

Assim, observamos que o docente precisa, além de compreender as necessidades da prática pedagógica na EJA, saber qual o tipo de metodologia que mais pode corresponder com o planejamento da aula e com o perfil daquele grupo de estudantes.

Não basta saber que as metodologias ativas são importantes. É fundamental o domínio dessas estratégias por parte docente, especialmente no contexto atual, mediado pelas tecnologias.

Sobre esse papel fundamental dos professores da EJA em relação ao domínio das metodologias ativas, buscamos apresentar alguns exemplos que podem ser utilizados. A pesquisa nos conduziu para os seguintes exemplos: Aprendizagem Baseada em Problemas (PBL), Sala de Aula Invertida, e Grupos Operatórios. As referidas metodologias são interessantes para a EJA porque estão centradas nos estudantes e em seus contextos, por permitirem a utilização de tecnologias (importante ferramenta para a interação no mundo contemporâneo), pela promoção da interação entre os sujeitos, e da autorresponsabilidade com os estudos.

Assim, cabe aos profissionais da EJA um aperfeiçoamento das suas técnicas pedagógicas para que utilizem metodologias ativas de ensino que garantam a permanência desses educandos na escola, proporcionando-lhes um ensino significativo, que os levem à análise crítica dos fatos abordados em sala de aula e do seu meio social.

\section{CONSIDERAÇÕES FINAIS}

Por meio desta pesquisa foi possível constatar que as metodologias ativas podem proporcionar melhores experiências educativas nesta modalidade de educação, pois valorizam os contextos dos estudantes, colocados como o centro do processo, ou seja, a utilização de metodologias ativas na EJA é uma estratégia pedagógica importante para tornar a referida modalidade mais interessante, o que pode contribuir com a diminuição dos números de evasão.

Consideramos também que não basta simplesmente utilizar aulas "diferentes" e afirmar que está aplicando uma metodologia ativa. Os educadores que estão na EJA precisam refletir as especificidades desta modalidade, principalmente nos seus planejamentos diários e 
projetos pedagógicos, assim como também é emergente que essa reflexão perpasse as políticas públicas.

Por fim, ponderamos que a temática tratada neste breve estudo é fundamental para o debate da educação, pois revelou importantes reflexões necessárias para o melhoramento das práticas pedagógicas no contexto da EJA, uma modalidade tão importante para fortalecer a democratização da educação com qualidade no Brasil. Ressaltamos ainda que, dada essa importância à temática, a discussão deve ser ampliada em novas pesquisas acadêmicas para que seja explorada a partir de perspectivas diferentes.

\section{REFERÊNCIAS}

BARBOSA, E. F.; MOURA, D. G. Metodologias ativas de aprendizagem na Educação Profissional e Tecnológica. Boletim Técnico Senac. Rio de Janeiro, 39(2), 48-67, 2013.

BECK, C. Metodologias Ativas: conceito e aplicação. ANDRAGOGIA Brasil. 2018. Disponível em: https://andragogiabrasil.com.br/metodologias-ativas/. Acesso em: 18 jun. 2020.

BERBEL, N. A. N. As metodologias ativas e a promoção da autonomia de estudantes. Semina: Ciências Sociais e Humanas, Londrina, v. 32, n. 1, p. 25-40, Jan/Jun, 2011.

BRAGA, Fabiana Marini; FERNANDES, Jarina Rodrigues. Educação de Jovens e Adultos: contribuições de artigos em periódicos brasileiros indexados na base SCIELO (2010-2014). Cad. CEDES, vol. 35, n. 96, Campinas: maio/ago. 2015. https://doi.org/10.1590/CC010132622015723757.

BRASIL. Lei de Diretrizes e Bases da Educação Nacional - LDB. Lei n. 9.424, de 24 de dezembro de 1996.

COSTA, Martins Cabral. (org.) Metodologias ativas: métodos e práticas para o século XXI. Quirinópolis, GO: Editora IGM, 2020.

FREIRE, Paulo. Pedagogia da autonomia: saberes necessários à prática educativa. São Paulo: Paz e Terra, 2004.

FREIRE, Paulo. Pedagogia do oprimido. Rio de Janeiro: Paz e Terra, 2005.

MARTINS, R. M. K. Pedagogia e andragogia na construção da educação de jovens e adultos. Rev. Ed. Popular, Uberlândia, v. 12, n. 1, p. 143-153, jan./jun. 2013. 
MORAN, J.; BACICH, L. Metodologias ativas para uma educação inovadora: uma abordagem teórico-prática. Porto Alegre: Penso, 2018.

MOREIRA, Marco Antônio; ELCIE, F. S. M. Aprendizagem significativa: a teoria de David Ausubel. São Paulo: Editora Moraes, 1982.

PAIVA, M. R. F. Metodologias Ativas de Ensino-Aprendizagem. 2016. Disponível em: http://www.scielo.br/pdf/spp/v14n2/9782.pdf. Acesso em: 25 jun. 2020.

PEREIRA, E. A; MARTINS, J. R.; ALVES, V. S.; DELGADO, E. I. A contribuição de John Dewey para a Educação. Revista Eletrônica de Educação. São Carlos, SP: UFSCar, v.3, no. 1, p. 154-161, mai. 2009. Disponível em: http://www.reveduc.ufscar.br/index.php/reveduc/article/view/38/37. Acesso em: 20 jun. 2020.

PINTO, Álvaro Vieira. Sete lições sobre educação de adultos. 16. ed. São Paulo: Cortez, 2010.

RIBEIRO, Luis Roberto de Camargo; MIZUKAMI, Maria da Graça Nicoletti. Uma Implementação da Aprendizagem Baseada em Problemas (PBL) na Pós-Graduação em Engenharia sob a Ótica dos Alunos. Revista UEL, Londrina, v. 25, p. 89-102, set. 2004.

SCHNEIDERS, Luís Antônio. O método da sala de aula invertida (flipped classroom). Lajeado-RS: Ed. UNIVAT ES, 2018.

XAVIER, C. F. História e Historiografia da Educação de Jovens e Adultos no Brasil inteligibilidades, apagamentos, necessidades, possibilidades. Revista Brasileira de História da Educação, v. 19, e068. 2019. Universidade Federal de Alfenas. DOI: https://doi.org/10.4025/rbhe.v19.2019.e068. 


\title{
TECNOLOGIA DA INFORMAÇÃO COMO FERRAMENTA PARA A LOGÍSTICA
}

\author{
https://dx.doi.org/10.48097/2674-8673.2021n5p16
}

\author{
Arandi Maciel Campelo ${ }^{1}$ \\ Lucas Emanuel Sousa da Veiga Pessoa ${ }^{2}$ \\ Matheus Rebelo Vilarim Pires ${ }^{3}$
}

\section{RESUMO}

Atualmente a tecnologia vem auxiliando o homem a alcançar resultados nunca vistos antes na história. Cabe ao mesmo saber como lidar com essa tecnologia a sua volta e usá-la de forma correta para assim chegar ao seu objetivo de forma rápida, fácil e com o mínimo de esforço possível. Com os avanços dos métodos computacionais nas últimas décadas, tal fenômeno proporcionou o desenvolvimento de novas ferramentas que servem de apoio para as práticas logísticas, trazendo assim pontos positivos na execução e no controle, proporcionando assim o seu desenvolvimento. A tecnologia hoje vem desempenhando um papel de destaque dentro das organizações, oferecendo ferramentas de natureza computacional aos métodos logísticos que são empregados nas empresas. Foi possível observar na pesquisa os benefícios de sua adoção por parte das organizações, uma vez que suas ferramentas se tornam vitais para o sucesso dentro de um mercado cada vez mais competitivo. Este artigo foi construído a partir de pesquisas bibliográficas realizada em 2020, tendo como principais fontes Ballou (2006) e Arozo (2003). A pesquisa revelou que é de suma importância a área de Tecnologia da Informação (TI) focada nos processos logísticos, pois agiliza cada vez mais os diversos setores de uma empresa.

Palavras-chave: Tecnologia da Informação. Logística. Ferramentas tecnológicas.

Data de submissão: 17/03/2021

Data de aprovação: $27 / 04 / 2021$

\begin{abstract}
Nowadays technology has been helping man to achieve results never seen before in history. It is also up to you to know how to deal with this technology around you and use it correctly in order to reach your goal quickly, easily and with the least possible effort. With the advances in computational methods in recent decades, this phenomenon has provided the development of new tools that support logistical practices, thus bringing positive points in execution and

\footnotetext{
${ }^{1}$ Orientador: Doutor em Educação - Universidade Federal de Pernambuco; Administrador - Universidade de Pernambuco - FCAP/UPE; Mestre em Planificación y Gestion Organizacional - Universidad Autonoma de Madrid / Espanha; Mestre em Dirección y Organización de Hospitales y Servicios de Salud - Universidad Politécnica de Valencia / Espanha; Especialista em Marketing - FCAP/UPE; Consultor em Sistemas Organizacionais, desde 1984; Professor e Diretor Acadêmico da Faculdade Metropolitana da Grande Recife. Email: arandi.campelo@globo.com

${ }^{2}$ Estudante do curso de Tecnólogo em Logística, da Faculdade Metropolitana da Grande Recife. E-mail: lucascerde@gmail.com

${ }^{3}$ Estudante do curso de Tecnólogo em Logística, da Faculdade Metropolitana da Grande Recife.

E-mail: Matheus_jynx@hotmail.com
} 
control, thus providing their development. Technology today has played a prominent role within organizations, offering computational tools to the logistical methods that are employed in companies. It was possible to observe in our research the benefits of its adoption by organizations, since its tools become vital for success in an increasingly competitive market. This article was built from bibliographic research carried out in 2020, with Ballou (2006) and Arozo (2003) as its main sources. The research revealed that the area of Information Technology (IT) focused on logistics processes is extremely important, as it increasingly streamlines the various sectors of a company.

Keywords: Information Technology. Logistics. Technological tools.

\section{INTRODUÇÃO}

Hoje os avanços tecnológicos tem proporcionado à humanidade um patamar de informação jamais visto antes na história da humanidade. $\mathrm{O}$ mundo tornou-se um espaço onde tudo está interligado. Grande parte desse nível de informação se deve à evolução computacional e à rede mundial de computadores.

\footnotetext{
A evolução da tecnologia da informação tornou possível um meio global de comunicação com total disponibilidade de informação, juntamente com a estabilidade de informações, juntamente com o estabelecimento de uma nova fronteira digital, para caminhar na direção de uma economia globalizada. (DI SERIO, 2001, p. 27).
}

Devido a essa evolução no nível de informação, o modo de tratamento dela também evoluiu, surgindo assim como ferramenta de tratamento dessas informações a Tecnologia da Informação. Segundo pesquisa realizada pelo SEBRAE (2008) cerca de 60\% das micro e pequenas empresas no país fazem investimentos em Tecnologia da Informação. Em 2009 esses investimentos atingiram US\$ 7,4 bilhões.

Atualmente, não basta apenas oferecer um serviço ou determinado produto para um mercado consumidor. As organizações têm que levar em conta vários estudos de mercado como, por exemplo, a condição financeira da população, como esse produto será distribuído e qual o retorno de lucro para a organização. Tais informações podem determinar a vida ou morte das empresas. A tecnologia vem atuando como um importante papel nos processos de planejamento, implementação e controle das organizações de uma forma bem satisfatória tanto para o consumidor como para as empresas que adotam essa prática.

\section{REFERENCIAL TEÓRICO}

Este quesito tem como objetivo apresentar a base teórica que sustenta o estudo proposto. Diante dessa proposição, faz-se necessário percorrer a literatura referente ao contexto de 
sistema da informação com ênfase na aplicação logística bem como ferramentas e sistemas aplicados a mesma.

\section{A LOGÍSTICA}

A logística é percebida como a competência que vincula a empresa a seus clientes e fornecedores. De acordo com o Council of Supply Chain Management Professionals CSCMP, a logística consiste no processo de planejamento, implementação e controle de forma eficiente e eficaz, do fluxo e armazenagem de produtos, serviços desde o ponto de origem até o ponto de consumo, em conformidade com as demandas do cliente.

Detalhando o conceito de logística: é a busca de otimização das atividades de processamento de pedidos, dimensionamento e controle de estoques, transporte, armazenagem e manuseio de materiais, projetos de embalagem, compras e gerenciamento de informações correlatas às atividades de forma a prover valor e melhor nível de serviço ao cliente. A busca pelo ótimo padrão dessas atividades é orientada para a racionalização máxima do fluxo do produto/serviço do ponto de origem ao ponto do consumo final, portanto, ao longo de to da a cadeia de suprimentos. (SALLES, 2000, p. 57).

Para Ballou (2006), a logística deve ser entendida a partir de uma visão sistêmica na qual:

\footnotetext{
A logística é um conjunto de atividades funcionais inter-relacionadas (transportes, controles de estoques, etc.), que se repetem inúmeras vezes ao longo do canal pelo qual matérias-primas vão sendo convertidas em produtos acabados, aos quais se agrega valor ao consumidor. (BALLOU, 2006, p. 29).
}

Pode-se definir logística como sendo a união de quatro atividades básicas: as de aquisição, movimentação, armazenagem e entrega de produtos. O termo logístico, de acordo com o dicionário Aurélio, vem do Francês logistique e tem como uma de suas definições: parte da arte da guerra que trata do planejamento e da realização de projetos e desenvolvimento, obtenção, armazenamento, transporte, distribuição, reparação, manutenção e evacuação de material para fins operativos ou administrativos. (AURÉLIO, 2007).

Nas organizações atuais, sendo elas públicas ou privadas, podemos observar uma interligação do mercado onde todos dependem de todos, sendo uma hora ofertante, outra hora ofertada por serviços ou produtos. O uso dos serviços logísticos está presente em empresas de transportes, alimentícias, forças armadas, serviços postais, distribuição de petróleo, transporte público, e muitas outras. Toda essa integração chama-se mercado globalizado. Uma boa consistência das informações soa de fundamental importância no mercado tanto para a 
obtenção de informações como para a disponibilização de serviços provenientes das necessidades observadas no mercado.

A logística tem como foco principal a diminuição de gastos para as empresas, aumentando a rentabilidade das atividades exercidas, sendo essas das obtenções ou distribuição e armazenagem, tornando assim algo fundamental tanto para as organizações quanto para os clientes, pois se mostra eficaz na busca de soluções para tais problemas de mercado.

Atualmente, as organizações têm sido desafiadas a operar de forma eficiente e efic az, buscando um diferencial que a faça garantir a continuidade de suas atividades dentro de um mercado cada vez mais exigente e competitivo. A logística realmente vem sendo uma atividade implementada com sucesso. Várias empresas que visam aumentar a rentabilidade de suas atividades modernizam seu modelo logístico.

\section{TECNOLOGIA DA INFORMAÇÃO}

A Tecnologia da Informação (TI) ou, em inglês, Information Technology (IT), pode ser definida como o conjunto de todas as atividades e soluções providas por recursos computacionais que visam permitir a obtenção, o armazenamento, a proteção, o processamento, o acesso, o gerenciamento e o uso das informações.

Esse conjunto de soluções é composto, essencialmente, por uma combinação de equipamentos (hardware) e de programas ou aplicativos (software).

a) Hardware: PCs, notebooks, servidores, tablets, smartphones, equipamentos de redes (como roteadores e switches), impressoras, leitores de códigos de barra, entre outros;

b) Software: sistemas operacionais, aplicativos (programas), protocolos de comunicação, antivírus, soluções de ERP, certificados digitais, tecnologias como blockchain, e outros.

\section{Evolução da Tecnologia da Informação}

A importância da informação no mercado tão globalizado como nos dias de hoje é um dos protagonistas pelo crescimento do mercado de TI. A tecnologia da informação pode ser decisiva para o sucesso ou fracasso de uma empresa, contribuindo assim para que a organização seja ágil, flexível e forte.

Os computadores surgiram de forma rudimentar e hoje permitem uma melhor integração entre os usuários e os especialistas de TI, abrindo caminhos para novas descobertas 
tecnológicas. Definitivamente, os microcomputadores ganharam espaço e tornaram-se popularizados devido ao preço e à capacidade de armazenamento de informação. O principal propósito de coletar, manter e manipular os dados dentro da empresa é o de auxiliar a tomar decisões, abrangendo desde o estratégico até o operacional. Estas atividades foram conduzidas informalmente por vários anos. Entretanto, com a disponibilidade de computadores de alta velocidade, que possuem capacidade de armazenagem de dados cada vez maior, os procedimentos em torno do manuseio de dados tornaram-se mais estruturados. (BALLOU, 2001, p. 109).

Os computadores tornaram-se muito mais velozes e de diferentes tamanhos. Seus meios de armazenamento têm maior capacidade, permitindo acessos aos dados de forma mais direta. Das tecnologias de entrada dos cartões e fitas de papel perfurado, chegou-se ao teclado, ao escaneamento óptico, e mais recentemente, ao reconhecimento de voz. Das tecnologias de saída dos relatórios impressos, evolui-se para as exibições de textos e gráficos em vídeo: os hipertextos multimídia.

Novos sistemas operacionais e programas para gerenciamento de redes locais tornaramse populares e mais fáceis de serem utilizados. Gerenciadores com novas funções e armazenamento de dados não estruturados já estão presentes no mercado.

\section{A importância da Tecnologia da Informação nas empresas}

TI é uma ferramenta essencial para as empresas, atualmente. Ela tem como objetivo aumentar o fluxo de informações trafegadas, ou seja, aumento das operações e atividades e competitividade no mercado, além de reduzir os custos da empresa, oferecendo estatísticas de crescimento em vendas, atendimento, raio de atuação, entre outros. A TI organiza as informações dentro da empresa, proporcionando rápido transporte da informação e oferecendo sigilo a dados que pertence somente à empresa.

Conforme citam Chopra e Meindln (2001), informação é essencial para tomar boas decisões de gerenciamento na cadeia de suprimentos porque ela proporciona o conhecimento do escopo global necessário para tomar boas decisões. (CHOPRA; MEINDLN 2001, p. 354).

De maneira geral, eficiência significa fazer bem as coisas, enquanto que eficácia significa fazer as coisas certas. A eficácia está associada ao uso dos recursos, enquanto a eficiência está associada com a satisfação de metas, objetivos e requisitos. A eficiência está relacionada com aspectos internos das atividades de TI e a adequada utilização dos recursos, enquanto que a eficácia confronta os resultados das aplicações de TI com os resultados no 
negócio da empresa e os possíveis impactos na sua operação e estrutura. Ser eficaz em TI significa utilizá-la para alavancar o negócio da empresa, tornando-a mais competitiva.

\section{Tecnologia da Informação na Logística}

A transferência de informações é de suma importância nas atividades logísticas, assim como os dados de clientes, controle de estoque, movimentação dentro do deposito, etc. Antigamente, estas informações eram trafegadas via papel, o que tornava a comunicação muito lenta e insegura, sujeito a erros. A transferência, armazenamento e gerenciamento informatizado dessas informações é tão eficaz quanto a prestação de serviços. Um exemplo é a troca de mensagens entre uma empresa e suas filias. Na matriz fica a TI onde são processados todos os dados das empresas, e as filias movimentam todas as vendas, o estoque, financeiro, e tudo isso através de um link que faz com que a mesma permaneça conectada. Outro exemplo é um web sites de compras em que há comodidade para o cliente fazer compras de onde estiver e o produto chegar na sua residência. Todos os processos ligados à informação e à logística estão diretamente ligados a um procedimento integrado, utilizando ferramentas informatizadas (hardware e software) para gerenciar as informações e operações em uma empresa.

De acordo com Bowersox e Closs (1996) ao abordarem a questão da necessidade de ter informações rápidas, em tempo real e com alto grau de precisão para que se possa gerir de forma eficiente a logística e a cadeia de suprimentos, apresentam três razões fundamentais:

Primeiro: clientes entendem que informações do andamento de uma ordem, disponibilidade de produtos, programação de entrega e dados do faturamento são elementos fundamentais do serviço ao cliente.

Segundo: com a meta da redução do estoque em toda a cadeia de suprimentos, os executivos percebem que com as informações adequadas eles podem, efetivamente, reduzir estoques e necessidade de recursos humanos, usando informações mais recentes, permitindo reduzir estoques através da minimização das incertezas da demanda.

Terceiro: a disponibilidade de informação, aumentando a flexibilidade com respeito ao saber quanto, quando e onde os recursos podem ser utilizados para obtenção de vantagens estratégicas. 


\section{Ferramentas de TI aplicadas à Logística}

Para que a TI tenha êxito nas execuções das tarefas é necessário definir sistemas que melhor atendem a necessidade da empresa, tendo em visita que a logística pode atuar em vários ramos e atividades. Segundo Bowersox e Closs (2001), o compartilhamento de informações gera várias vantagens como a redução do custo de processamento de pedidos, a diminuição das incertezas de planejamento e operações e a redução dos níveis de estoque.

\section{Warehouses Management System (WMS)}

Esse sistema é também conhecido como WMS. É uma tecnologia utilizada de forma gradual em armazéns, integrando e processando as informações de acordo com a localização do material. Segundo Arozo (2003), estes sistemas são responsáveis pelo gerenciamento da operação no cotidiano de um armazém. Sua utilização está restrita a decisões operacionais como, por exemplo, a definição de rotas de coleta e a definição de endereçamento dos produtos.

Conforme cita Banzato (1998), é um sistema de gestão de armazéns que aperfeiçoa todas as atividades operacionais (fluxo de materiais) e administrativas (fluxo de informações) dentro do processo de armazenagem, incluindo recebimento, inspeção, endereçamento, estocagem, separação, embalagem, carregamento, expedição, emissão de documentos, inventário, entre outras. As informações integradas atendem às necessidades logísticas, maximizando os recursos e minimizando desperdícios de tempo e de pessoas. Toda essa informação do estoque tem como ferramenta principal o coletor de dados que é um equipamento com capacidade de transmitir e receber rápidas informações de armazenagem quando conectados diretamente ao sistema através de uma rede sem fio.

\section{Enterprise Resource Planning (ERPs)}

Os sistemas empresariais (ERP) são sistemas de grande complexibilidade, integrando de forma eficaz todos os sistemas operacionais de uma empresa. Por ser um sistema que auxilia toda parte gerencial da empresa, sua adoção não é simples, exigindo da empresa pré-requisitos na sua implementação.

Podemos definir ainda que o ERP seja composto basicamente na integração de todas as atividades atuantes em uma empresa, podendo ser elas: produção, recursos humanos, finanças, transporte, etc. Tem como papel fundamental tornar o fluxo das informações algo visível e palpável, possibilitando assim uma tomada de decisão mais precisa. Esse sistema tem como 
característica a permissão de análise de custo-benefício de suas aquisições. Podemos observar algumas vantagens na sua aquisição por uma organização:

a) São desenvolvidos através de modelos padrões de processos;

b) Integram sistemas de várias áreas das empresas;

c) Utiliza um banco de dados centralizado;

d) Possuem grande abrangência funcional.

É necessário para a empresa identificar suas reais necessidades antes mesmo de pensar em adotar o sistema integrado para que assim ela possa ter sucesso na implantação do sistema. Como o projeto é de caráter amplo, a maioria das empresas perdem de vista as motivações originais e naufragam diante das dificuldades encontradas. (DEMPSEY, 1999).

\section{Customer Relationship Management (CRM)}

O CRM está relacionado principalmente à satisfação do cliente como prioridade, já que esse é um grande trunfo e garantia de sucesso de qualquer empresa. Ele possui todas as informações de dados relacionados às interações de compra e venda entre a organização e o consumidor. E, de posse destes dados, é possível prever demandas e necessidades do públicoalvo, permitindo com que a empresa se antecipe e atenda a todos esses anseios da melhor forma, aproximando e melhorando o contato com o cliente.

\section{Transportation Management System (TMS)}

O TMS é uma ferramenta de TI muito útil às transportadoras, pois ele auxilia principalmente no controle de informações relativas a fretes, entregas, eficiência de motoristas e veículos, roteiros de viagens, rastreamento das mercadorias, emissão de documentos fiscais de cargas, além de facilitar na emissão de Notas Fiscais Eletrônicas (NF-e). Ele possui também o diferencial de otimizar a qualidade e a produtividade em todo o processo de transporte, permitindo uma maior integração e controle de toda operação.

\section{Softwares de rastreamento de remessas}

Essas ferramentas estão relacionadas principalmente à comodidade de poder acompanhar todo o processo de entrega durante todo o trajeto. Com informações em tempo real sobre as compras, esse recurso otimiza tanto a relação com o cliente como organiza o trabalho das empresas. 


\section{Softwares de gestão de estoque}

Essas ferramentas de gestão de estoque fornecem informações precisas para os gestores de logística sobre a real situação do estoque. Desta forma, evita-se contratempos como a indisponibilidade de produtos ou excessos na armazenagem.

\section{Empresas Fornecedoras}

Algumas das principais empresas fornecedoras desse tipo de software no mundo já estão no Brasil. A SAP, além de ocupar a liderança mundial neste mercado, tamb ém ocupa essa posição no Brasil com 38\% das vendas de licença de software. Por outro lado, a Datasul possui o maior número de clientes, com $23 \%$ do mercado.

Alguns exemplos de sucesso da implantação de sistemas ERP:

a) Autodesk - passou a embarcar 98\% de seus pedidos dentro de 24 horas após a implantação de um ERP;

b) Votorantim - o giro do estoque melhorou de 30 a 40\% e o número de funcionários administrativos pôde ser reduzido em 30\%, resultando em ganhos de US\$ 6 milhões anuais;

c) Indústria média norte-americana de autopeças - reduziu o tempo entre o pedido e a entrega de seis para duas semanas. Outra diferença notável: a troca de documentos entre departamentos que demorava horas ou mesmo dias caiu para minutos e até segundos.

\section{METODOLOGIA}

Foi utilizado o método de pesquisa descritiva com a finalidade de analisar e explicar os sistemas da tecnologia da informação focados na área de logística. Partindo de uma revisão bibliográfica composta pelos principais autores da área, o método de análise é explicativo e de abordagem qualitativa. A experiência da pesquisa bibliográfica foi de suma importância para aguçarmos o conhecimento mais especifico dos sistemas no âmbito logístico, detalhando e definindo as operações e etapas.

\section{CONSIDERAÇÕES FINAIS}

A tecnologia pode ser considerada também como uma potente força no sentido de capacitar uma extensão nas habilidades humanas. Portanto, a tecnologia da informação deve ser vista como suporte aos processos de logística e nas decisões operacionais e de negócios 
das organizações. Um recurso tecnológico bem empregado em um ambiente empresarial pode tornar-se um grande aliado no que diz respeito às vantagens competitivas. Observa-se também outra vantagem que a tecnologia da informação fornece para a logística: uma grande perspectiva de crescimento para o mercado, justificado pelo tamanho do mercado existente, atualmente, sendo que as vantagens baseadas no crescimento da TI em logística ocorrem com o atendimento da necessidade de aquisição da tecnologia de informação para integração da cadeia produtiva, a fim de atender o cliente final.

É atualmente a fonte de vantagem competitiva mais cobiçada no mercado, porém devem ser repensados os processos organizacionais e seu redesenho. Toda a tecnologia que hoje está à disposição da solução da logística empresarial é capaz de gerar soluções que satisfaçam qualquer necessidade de mercado. De um modo geral, o sucesso da implantação de sistema logísticos nas empresas e as vantagens advindas de sua aplicação dependem do processo de amadurecimento empresarial. Dessa forma, conclui-se que a TI é peça fundamental para o crescimento das empresas que pretendem disparar na frente no mercado competitivo, podendo, assim, atender seus clientes com muito mais eficiência, eficácia e rapidez.

\section{REFERÊNCIAS}

AURÉLIO, Buarque de Holanda Ferreira. Dicionário Aurélio da língua Portuguesa. São Paulo: Positivo, 2007.

AROZO, R. (2003). Softwares de supply chain management: Definições, principais funcionalidades e implantação por empresas brasileiras. Disponível em: https://www.ilos.com.br/web/software-de-supply-chain-management-parte-1/. Acesso em: 17 jun. 2020.

BOWERSOX, Donald J.; CLOSS, David J. Logística empresarial. São Paulo: Atlas, 2001.

BOAR, Bernard H. Tecnologia da Informação. São Paulo: Berkeley, 1999.

BANZATO, E. WMS - Warehouse management system: Sistema de gerenciamento de armazéns. São Paulo: IMAN, 1998.

BALLOU, Ronald H. Logística empresarial: transporte, administração de materiais e distribuição física. 5. ed. Porto Alegre: Bookman, 2006.

CHOPRA, Sumil; MEINDL, Peter. Supply Chain Management: Strategy, Planning, and Operation. New Jersey: Prentice-Hall, Inc., 2001. 
CRUZ T. Sistemas de Informações Gerenciais: Tecnologias da Informação e a Empresa do Sec. XXI. São Paulo: Atlas, 2010.

DEMPSEY, M. Pacote de ERP não resolve tudo. Disponível em: http:// www.scielo.br. Acesso em: 12 jun. 2020.

FLEURY, P. F.; WANKE, P. Logística e gerenciamento da cadeia de suprimentos: planejamento do fluxo de produtos e dos recursos. São Paulo: Atlas, 2003.

LAURINDO, Fernando J. Barbin. Tecnologia da Informação: eficácia nas organizações. São Paulo: Futura, 2002.

SALES, Alessandra Simoni Ferraz; FERREIRA, Marilene Lopes. Gestão Estratégica da Informação na Logística. REUNA: Revista de Economia da UNA, v. 7, n. 2, abr.jun. 2000.

SEBRAE. Serviço Brasileiro de Apoio às Micro e Pequenas Empresas. 10 Anos de Monitoramento da Sobrevivência e Mortalidade de Empresas. 2008. Disponível em: https://m.sebrae.com.br/Sebrae/Portal\%20Sebrae/UFs/SP/Pesquisas/10_anos_mortalidade_rel atorio_completo.pdf. Acesso em: 20 jun. 2020. 


\title{
TELETRABALHO E SUAS COMPLEXIDADES
}

\author{
https://dx.doi.org/10.48097/2674-8673.2021n5p17
}

Wellington Cosme da Silva ${ }^{1}$

Camila Ferreira Lima de Albuquerque Brito ${ }^{2}$

\section{RESUMO}

Opresente artigo tem como objetivo estudar a modalidade de trabalho a distância, o teletrabalho, no atual cenário mundial, desenvolvido e controlado por meio do uso das tecnologias de informação e comunicação, abordando as principais temáticas, inclusive a diferença em relação ao trabalho em domicílio, sendo o teletrabalho uma forma de flexibilidade da atividade laboral que trouxe vantagem e desvantagem ao funcionário, em relação à jornada de trabalho. A intensão é refletir sobre o aprimoramento do regime de teletrabalho de forma a conciliar a produtividade e a saúde mental dos trabalhadores. A problemática em relação à flexibilização está relacionada à relação de emprego, ou seja, a aplicabilidade da jornada de trabalho e as horas extras e critérios de subordinação, com o advento da reforma trabalhista (Lei n. 13.467/2017), das regras sobre teletrabalho previstas na Consolidação das Leis Trabalhistas (CLT) e aquelas presentes na Medida Provisória $\mathrm{n}^{\circ}$ $927 / 20$, em função da calamidade pública, entendendo-se que devem ser preservados dois direitos sociais fundamentais: saúde e trabalho.

Palavras-chave: Teletrabalho. Relação de emprego. Jornada de trabalho. Pandemia. Reforma trabalhista.

Data de submissão: 20/01/2021

Data de aprovação: 18/03/2021

\begin{abstract}
This article aims to study the distance work modality, telework, in the current global scenario, developed and controlled through the use of information and communication technologies, addressing the main themes, including the difference in relation to homework, as teleworking is a form of flexibility in the work activity that brought advantages and disadvantages to the employee, in relation to the working day. The intention is to reflect on the improvement of the telework regime in order to reconcile workers' productivity and mental health. The problem in relation to flexibility is related to the employment relationship, that is, the applicability of working hours and overtime and subordination criteria, with the advent of the labor reform (Law n.13.467/2017), of the rules on telework foreseen in the Consolidation of Labor Laws (CLT) and those present in Provisional Measure $n^{\circ} 927 / 20$, due to the public calamity, understanding that two fundamental social rights must be preserved: health and work.
\end{abstract}

Keywords: Telework. Employment relationship. Working time. Pandemic. Labor reform.

\footnotetext{
${ }^{1}$ Graduando em Direito pela Faculdade Metropolitana da Grande Recife - FMGR.

E-mail: wellingtsilva@hotmail.com

${ }^{2}$ Advogada, mestranda e professora da Faculdade Metropolitana da Grande Recife, Faculdade de Ciências

Aplicada de Limoeiro - FACAL e Curso de Aplicação. E-mail: profa.camilalima@cursodeaplicacao.com.br
} 


\section{INTRODUÇÃO}

Este artigo tem como objetivo analisar os aspectos que cercam o teletrabalho, analisando suas particularidades, características, estrutura e validade, dentro do cenário atual.

A possibilidade de trabalhar em casa tem motivado muitos trabalhadores e empresas. É nítido que, no momento atual (período de pandemia), o número de colaboradores que não se veem obrigados a se deslocar de suas residências para a empresa e realizar as atividades laborais teve um aumento significativo.

Isso só é possível devido à evolução das tecnologias que têm alterado a realização de inúmeras atividades, cotidianas ou não, que dispensam o deslocamento físico do ser humano. Já no tocante ao teletrabalho, ou seja, trabalhar fora da empresa, esse tipo de atividade existe há bastante tempo. Todavia, o que há de diferente é a inclusão do uso de tecnologia, fazendo com que as atividades econômicas cada vez mais mantenham distância das tradicionais, ou seja, grupo de trabalhadores aglomerados. É perceptível que o teletrabalho apresenta vários termos, tais como: home office, trabalho remoto, trabalho a distância, etc. Estes profissionais fazem contatos com clientes, formam equipes de trabalho, realizam projetos e trocam informações sempre que necessário. Desta forma, o trabalhador poderá realizar algumas atividades a distância em qualquer lugar, reduzindo assim a distância existente entre trabalhador/empresa e seus clientes. Essas ferramentas são mais usadas na área de tecnologia, pois se trata de trabalho mais flexível, equilibrando a produtividade com a qualidade de vida (ROCHA, 2014). Haja vista que as grandes empresas buscam constantemente uma forma de aumentar a lucratividade e competitividade com seus concorrentes.

Com o advento da Lei 13.467/17, que alterou alguns artigos da Consolidação das Leis Trabalhistas (CLT), a mencionada lei também trouxe benefícios aos trabalhadores, tais como: otimização do tempo de deslocamento de ida e vinda ao trabalho; maior flexibilidade e autonomia de horários, visando à qualidade de vida, e assim, respeitando a dignidade da pessoa humana, conforme descreve a Constituição Federal; além da redução de despesas pelo empregador, entre outros.

Desde o período da Idade Média, com a criação das pequenas oficinas, sala do artesão, e mais tarde com o surgimento da Revolução Industrial, vieram as máquinas a vapor que trouxeram grande aumento da produção e assim mais agilidade. Segundo Martins (2014), as oficinas dos artesãos foram sendo substituídas pelas fábricas e as ferramentas foram sendo substituídas pelas máquinas. Logo, surgiram associações de trabalhadores e, consequentemente, as normas jurídicas relativas à proteção dos colaboradores. Surge, então, o Direito do Trabalho, reconhecido pelo Estado, que passou a regulamentar o direito individual 
do trabalho, com o intuito de proteger o trabalhador de práticas ilícitas por parte do empregador. (PASCHOAL, 2018, p. 27).

Dessa forma, a associação dos trabalhadores, na defesa dos seus direitos, teve grande influência no aparecimento no Direito Trabalhista, pois conforme cita Silva (2012) a ação dos trabalhadores reunidos em associações na defesa dos direitos comuns veio a constituir-se em uma das mais evidentes forças modeladoras do Direito do Trabalho, sendo o fator determinante para o seu surgimento como ciência jurídica.

No Brasil, com o advento da Consolidação das Leis Trabalhistas (CLT), houve várias proteções ao trabalhador. Entretanto, a evolução tecnológica trouxe novos formatos de trabalho, ou seja, a figura do teletrabalho. Este novo modelo de trabalho apresenta a busca de uma forma de atividade mais flexível.

\section{O TELETRABALHO}

O teletrabalho é uma espécie de trabalho que surgiu com o advento da tecnologia e, segundo Bomfim (2018, p. 133-135), é um trabalho à distância, realizado fora do estabelecimento do empregador. O teletrabalho pode ser desenvolvido no domicílio do empregado ou em um centro de computação, um escritório virtual ou alugado por hora para este fim.

No Brasil, por muito tempo, foram usados os termos telecentro ou centro satélite de telesserviço para se referir a teletrabalho. Ao longo dos tempos pairavam dúvidas em considerar ou não as tecnologias da informação e de comunicação como essenciais no teletrabalho, ou até mesmo se o teletrabalho era uma espécie de "trabalho a distância" ou "trabalho em domicílio". Não devemos afirmar que teletrabalho é apenas domiciliar, visto que não se limita ao domicílio, pois o lugar de trabalho neste formato se dá em qualquer ambiente acessível à rede mundial de computadores.

Logo, podemos verificar que o trabalho a distância se refere às espécies de teletrabalho e trabalho em domicílio. Neste sentido, o entendimento de Silveira e Silva (2004) é de que

o teletrabalho, sendo o trabalho exercido total ou parcialmente distante da empresa de forma telemática diferencia-se do trabalho em domicílio, já que este, em regra, acontece fora da empresa e sem contato pessoal com a mesma, e ainda, utiliza-se dos meios normais de comunicação como o telefone e fax, enquanto o teletrabalho é norteado por alta tecnologia. (SILVEIRA E SILVA, 2004, p. 102-109). 
A Organização Internacional do Trabalho (OIT) traz a definição de teletrabalho como qualquer trabalho feito distante dos escritórios/empresa, onde o trabalhador não mantem qualquer contato pessoal como seus colegas, mas a comunicação se faz por meio da tecnologia. O legislador, ao modificar o artigo $6^{\circ}$ da CLT, através da Lei $\mathrm{n}^{\circ} 12.551$ de 2011, escolheu o trabalho a distância de modo genérico.

\footnotetext{
Art. $6^{\circ}$ Não se distingue entre o trabalho realizado no estabelecimento do empregador, o executado no domicílio do empregado e o realizado a distância, desde que estejam caracterizados os pressupostos da relação de emprego.

Parágrafo único. Os meios telemáticos e informatizados de comando, controle e supervisão se equiparam, para fins de subordinação jurídica, aos meios pessoais e diretos de comando, controle e supervisão do trabalho alheio.
}

Nesse sentido, o legislador considera trabalho realizado por meios tecnológicos equiparando ao trabalho realizado presencialmente, todavia, deverá conter os requisitos da pessoalidade, a não eventualidade, a subordinação e a onerosidade, nos termos do parágrafo único do artigo $6^{\circ}$ e artigo $3^{\circ}$, ambos da CLT.

\section{Diferença entre teletrabalho e trabalho em domicílio}

O termo teletrabalho está relacionado ao trabalho remoto, por meio da tecnologia da informação e comunicação - TIC. É importante frisar que há atividades que têm maior identificação com o termo trabalho em domicílio do que teletrabalho. (HOLZMANN, 2011).

$\mathrm{O}$ trabalho remoto não está ligado diretamente à produção industrial, e sim ao uso de TIC, o qual teve o surgimento nos anos 1970, levando à noção de "trabalho a distância" e "trabalho em casa". O segundo termo, embora nos remeta à ideia de trabalho em domicílio, é uma premissa falsa, pois o trabalho em domicílio na maioria das vezes não é teletrabalho. Já o trabalho a distância compreende várias espécies, e uma delas é o teletrabalho, definido por Garcia (2017) como:

uma modalidade de trabalho a distância, típica dos tempos modernos, em que o avanço da tecnologia permite o labor preponderantemente fora do estabelecimento do empregador (normalmente na própria residência do empregado), embora mantendo o contato com este por meio de recursos. (GARCIA, 2017, p. 352$353)$.

Apesar das semelhanças, há que se destacar que o teletrabalho pode ser realizado em qualquer lugar, desde que longe do ambiente empresarial. Já o trabalho em domicílio está relacionado à moradia do empregado ou um lugar escolhido por ele. Ambos os termos estão ligados ao universo da organização do trabalho, referindo-se à atual tendência das atividades laborais sem que haja a necessidade de deslocamento do trabalhador ao local. 
Para facilitar o entendimento das diferenças acerca do trabalho à distância e do teletrabalho, destaca-se a citação de Delgado (2008):

O teletrabalho é realizado quando se utiliza de tecnologias que permitem que o trabalho seja feito fora do espaço da empresa. Porém, há um equívoco frequente que é comparar o teletrabalho ao trabalho em domicílio, visto que o teletrabalho não se limita ao domicílio. Assim, o lugar de trabalho hoje é, potencialmente, em qualquer ambiente onde a gestão de redes eletrônicas seja possível. (DELGADO, 2008, p. 234).

\section{Os tipos de teletrabalho}

As modalidades de teletrabalho são conceituadas por diversas maneiras pela Organização Internacional do Trabalho (OIT), em que se leva em consideração: a) local/ espaço de trabalho; b) horário/tempo de trabalho (integral ou parcial); c) tipo de contrato (assalariado ou independente); e d) competências requeridas (conteúdo do trabalho). Neste sentido, RUBENS VALTECIDES ALVES (2007) ressalta que

o teletrabalho abrange outros elementos, que não somente o domicílio do prestador de serviço. Com os recursos proporcionais pelos modernos sistemas de comunicação a distância, o teletrabalho pode ser exercido em qualquer local acordado pelos contratantes, ou seja, até locais virtuais onde, logicamente, não seja residência ou mesmo domicílio deles. (ALVES, 2007, p. 388).

De acordo com o artigo $6^{\circ}$ da CLT (Consolidação das Leis Trabalhistas), o teletrabalho em domicílio (home office) pode ser equiparado com o trabalho em domicílio normal. Todavia, o teletrabalho em domicílio é desenvolvido na residência do trabalhador, logo, é importante que a família se habitue a essa nova forma de trabalho e que haja um espaço específico para a realização desta modalidade. Assim, não deverá ser montado em área de circulação do restante da família (como a cozinha ou a mesa da sala de jantar). É notável que as ferramentas do trabalho flexível ou remoto, denominado teletrabalho, são de uso pessoal ou não, doados pelo empregador ou não.

\section{Aspectos jurídicos do teletrabalho}

A Constituição Federal de 1988 em seu artigo $7^{\circ}$, inciso XXVII, assegura a proteção do trabalhador em face da automação, na seguinte redação:

Art. $7^{\circ}$ São direitos dos trabalhadores urbanos e rurais, além de outros que visem à melhoria de sua condição social: (...)

XXVII - proteção em face da automação, na forma da lei;

Assim sendo, o teletrabalho necessitava de uma norma que a regulamentasse. A primeira referência com trabalho a distância (teletrabalho) foi descrita na lei número 
12.551/2011, que altera o art. $6^{\circ}$ da CLT, no qual equiparou o trabalho a distância ao trabalho realizado presencialmente:

Art. $6^{\circ}$ Não se distingue entre o trabalho realizado no estabelecimento do empregador, o executado no domicílio do empregado e o realizado a distância, desde que estejam caracterizados os pressupostos da relação de emprego.

Parágrafo único. Os meios telemáticos e informatizados de comando, controle e supervisão se equiparam, para fins de subordinação jurídica, aos meios pessoais e diretos de comando, controle e supervisão do trabalho alheio (BRASIL, 2011).

Com o advento da Lei $\mathrm{n}^{\circ} 13.467 / 2017$, conhecida como reforma trabalhista, houve importantes alterações na Consolidação das Leis Trabalhistas e, consequentemente, no modo pelo qual o trabalho é realizado. Segundo Bomfim(2018), a Lei 13.467/2017 pacificou as controvérsias a respeito do conceito e direitos do teletrabalhador quando incluiu o artigo 75-B e seguintes da CLT, que determinam que:

Art. 75-B. Considera-se teletrabalho a prestação de serviços preponderantemente fora das dependências do empregador, com a utilização de tecnologias de informação e de comunicação que, por sua natureza, não se constituam como trabalho externo.

Parágrafo único. O comparecimento às dependências do empregador para a realização de atividades específicas que exijam a presença do empregado no estabelecimento não descaracteriza o regime de teletrabalho.

Embora a lei 12.551/2011 tenha dado relevância ao teletrabalho, com a reforma trabalhista veio o reconhecimento dessa modalidade laboral. É certo que mesmo com alteração do artigo $6^{\circ}$ da CLT, não foi suficiente para suprir as lacunas relacionadas ao teletrabalho, de modo que só foi possível sanar de maneira clara e objetiva as dúvidas com o surgimento da reforma trabalhista. Assim, o conceito de teletrabalho está agora estampado no artigo 75-B da CLT.

Outra característica específica do teletrabalho é em relação ao contrato. O empregador poderá alterar o regime do contrato de trabalho de presencial para teletrabalho somente com anuência do empregado, por meio de aditivo contratual, e poderá alterar de regime de teletrabalho para presencial sem anuência do empregado, também por meio de aditivo contratual, mas deverá conceder um prazo de 15 dias de adaptação, conforme art. 75-C e seus parágrafos.

Todavia, a responsabilidade pela aquisição, manutenção e fornecimento dos equipamentos para que o trabalho remoto seja desenvolvido, bem como os custos com a infraestrutura, serão de responsabilidade do empregador. Assim, os bens econômicos disponibilizados pelo empregador para a realização do trabalho não serão considerados salário utilidade, conforme artigo 75-D. 
Segundo Caetano (2019), é do empregador a responsabilidade de instruir os empregados sobre a prevenção de acidentes ou doenças do trabalho, e o empregador deverá assinar termo de responsabilidade escrito, confirmando que recebeu as instruções, a fim de evitar eventual acidente ou doença do trabalho, conforme artigo 75-E e seu parágrafo único.

\section{RELAÇÃO DE EMPREGO}

As leis trabalhistas são voltadas para a proteção do trabalhador subordinado, entretanto, o teletrabalho pode ser de caráter autônomo ou subordinado. Vale destacar que o teletrabalho autônomo é aquele que presta serviços sem vínculo de subordinação, ou seja, não tem obrigação ao controle do empregador. Sendo assim, é o responsável pelas atividades e assume os riscos do negócio. Já o trabalhador subordinado é aquele que trabalha de forma não eventual, sob dependência do empregador, do qual recebe uma remuneração.

Autores como Dutra e Villatore (2014) afirmam que a subordinação se encontra presente na relação de teletrabalho. O legislador, ao modificar o parágrafo único do artigo $6^{\circ}$ da CLT, através da lei $\mathrm{n}^{\mathrm{o}} 12.551$, de 2011, aplicou o critério da subordinação, ao citar que "os meios telemáticos e informatizados de comando, controle e supervisão se equiparam, para fins de subordinação jurídica, aos meios pessoais e diretos de comando, controle e supervisão do trabalho alheio". Todavia, estão presentes requisitos da pessoalidade, não eventualidade, subordinação e onerosidade. Em seu artigo 3ㄹ caput, a CLT dispõe: “considera-se empregada toda pessoa física que prestar serviços de natureza não eventual ao empregador, sob a dependência deste, e mediante salário". No artigo $2^{\circ}$, caput, por outro lado, determina: "considera-se empregadora a empresa, individual ou coletiva, que, assumindo os riscos da atividade econômica, admite, assalaria e dirige a prestação pessoal de serviços".

\section{Da subordinação}

$\mathrm{Na}$ relação de emprego há que se observar alguns critérios, entre eles o da subordinação, descrito nos arts. $2^{\circ}$ e $3^{\circ}$ da CLT e no parágrafo único do artigo $6^{\circ}$ da CLT. De acordo com Jardim (2004, p. 59), o critério para verificar sua natureza jurídica tem como centro a existência ou não da subordinação e da avaliação dos casos concretos. Para a jurista Vera Winter (2005, p. 57), deve-se observar a forma como vai realizar a atividade laboral, podendo ser tanto de natureza comercial quanto civil ou trabalhista. Schwarz (2007) afirma que de todos os elementos qualificadores de uma efetiva relação de emprego, a subordinação é a mais evidente manifestação de vínculo existente entre o empregado e o empregador. 
Assim, os teletrabalhadores permanentes ou temporais ficam grande parte do tempo, se não integralmente, sob a supervisão direta ou indireta de seu superior. Ainda que o empregador não esteja no mesmo espaço físico que o funcionário, o mesmo responde diretamente ao seu subordinado. Deste modo, o parágrafo único da lei ${ }^{\circ} 12.551 / 11$, ao citar, especificamente, o uso de meios viabilizadores do teletrabalho, deve levar em consideração os principais níveis de subordinação, conforme Jardim (2004, p. 64):

a) Subordinação hierárquica. Nasce com o contrato de trabalho, apresentando relação de subordinação, ou seja, hierarquia entre empregado e empregador;

b) Subordinação econômica. Predomina o recebimento da remuneração do empregado;

c) Subordinação técnica. O empregado depende de equipamentos ou do sistema do empregador, principalmente quando se trata de teletrabalho;

d) Subordinação jurídica. O empregado fica sujeito às ordens e direção do empregador.

Neste contexto, o empregado em teletrabalho apresenta todas as características da subordinação, pois o mesmo está, de forma contínua, ligada à empresa, por meio de uma ligação online ao computador, permitindo que o empregador o fiscalize, mesmo não estando presente no interior da empresa. Logo, não há em que se falar da não subordinação, pois mesmo fora do ambiente empresarial os requisitos dos artigos $2^{\circ}$ e $3^{\circ}$ da CLT continuam presente e sobre fiscalização e algumas situações têm maior controle por parte do empregador.

\section{Controle da jornada}

A reforma trabalhista trouxe algumas mudanças benéficas a essa modalidade de trabalho, entretanto, afastou a jornada de trabalho no que se refere ao art. 62, III da CLT quando cita que os empregados em regime de teletrabalho não são abrangidos pelo regime previsto neste capítulo.

Para Bomfim (2018), essa alteração no inciso III do art. 62 da CLT é maléfica ao trabalhador. Primeiramente, observa-se que o mencionado artigo equiparou o teletrabalho como atividade incompatível com a fixação de horário de trabalho e com os gerentes, passando a abarcar os empregados em regime de teletrabalho, pois, tais profissionais terão flexibilidade para realizar suas atividades como bem entenderem, com a justificativa que no teletrabalho existe impossibilidade de controle da jornada laboral. 
Em contrapartida, Ravagnani e Rodrigues (2018) destacam que a mensuração da jornada de trabalho enfrenta obstáculos em decorrência de elementos intrínsecos à essência do teletrabalho, quais sejam: a autonomia e a flexibilidade de horário para execução das atividades. Sendo assim, ainda que reconhecida a subordinação do teletrabalhador, tal elemento não atrairia absolutamente todos os aspectos de uma relação de emprego tradicional, haja vista as peculiaridades inerentes à forma como o serviço é prestado.

Todavia, no que diz respeito ao direito do teletrabalhador, a perceber o pagamento de horas extras quando sujeitas à sobrejornada, os autores reconhecem que a limitação constitucional de horas a serem trabalhadas não pode cair no esquecimento.

Neste sentido, Delgado (2017) indica que a regra instituída a partir do artigo 62, III, trata de presunção relativa, isto é, que o empregado, na medida em que presta serviços na modalidade de teletrabalho, está exercendo atividade incompatível com o controle de jornada e, consequentemente, o empregador se vê isento da realização do referido controle. Logo, a interpretação do artigo 62, III, deve ser feita tão somente nos casos em que não há fiscalização do teletrabalhador. (MAGALHÃES, 2017, p. 294).

\section{Vantagens e desvantagen $s$ do teletrabalho}

O teletrabalho é uma nova modalidade de trabalho no cenário atual, sendo que, de princípio, podemos pontuar algumas vantagens e desvantagens. Uma das principais vantagens diz respeito à flexibilização de horário e local de trabalho; à organização do tempo, de modo a melhor conciliar demandas sociais, familiares, laborais e de lazer; à economia de tempo com transporte casa-trabalho, evitando gasto com combustível, uso do precário serviço de transporte coletivo, diminuindo riscos no trânsito e até assaltos; além da autonomia para organização do modo de trabalhar, principalmente no que diz respeito ao espaço e ao tempo. Toda essa flexibilização só é possível devido ao surgimento das novas tecnologias, o que traz mudanças na sociedade, relativas ao tempo de emprego.

Santos \& Miranda (2017) demonstram o aumento de cursos na modalidade a distância, onde os professores passam a ser divididos em conteudistas e tutores virtuais. Nesse ponto, é importante destacar o teletrabalho, especificamente, na modalidade em domicílio.

Destacam-se também as vantagens para as empresas: redução de custos operacionais e logísticos; redução de custos com espaço físico, equipamentos e manutenção; aumento da produtividade dos trabalhadores; redução da falta/atraso do colaborador; retenção de talentos em regiões e até países diversos, aumentando a presença das organizações em pontos 
diferenciados; redução de riscos ao meio ambiente, pois, com menos poluição, beneficia toda a sociedade.

Todavia, como o teletrabalho proporciona benefícios, também acarreta algumas desvantagens para os próprios teletrabalhadores: a falta de contato direto com os colegas na troca de ideias e compartilhamento das dificuldades; transferência de valores e da cultura organizacional; custos para a implantação e manutenção do sistema de teletrabalho; maior isolamento do trabalhador; redução da subordinação; enfraquecimento da representação e ação sindical. (VALENTIM, 2000, p. 58-62).

Estas vantagens e desvantagens têm de ser analisadas antes da adoção desta relação, tanto por parte dos empregados quanto pelos empregadores.

\section{O TELETRABALHO EM TEMPOS DE PANDEMIA}

A Lei $n^{\circ} 13.467 / 2017$ (reforma trabalhista) especificou o tema do teletrabalho, trazida de forma genérica pelo artigo $6^{\circ}$ da Consolidação das Leis do Trabalho - CLT entre o trabalho a distância e o trabalho presencial. Há, ainda, os artigos 62, III e 611-A, VIII. O primeiro, para localizar o teletrabalho entre as formas de prestação de serviço subordinado, excluído do controle da duração de jornada; e o segundo, para citá-lo como tema factível de negociação coletiva. Até o decreto de calamidade, tinha-se o contrato de teletrabalho como um pacto especial e formal e requisito constante no art. $75-\mathrm{C}$ da CLT. Com o advento da Covid-19, foi publicada a lei $\mathrm{n}^{\mathrm{o}} 13.979 / 20$, que dispõe sobre as medidas para o enfrentamento da pandemia. Em relação ao Direito do Trabalho, as principais Medidas Provisórias editadas foram a 927, de 22 de março de 2020 e a 936, de 01 de abril de 2020.

Com a Medida Provisória (MP) houve uma maior flexibilização para a adoção do teletrabalho, pois poderá ser realizada a critério do empregador, independente de acordos individuais ou coletivos, sendo dispensado o registro prévio da alteração no contrato individual de trabalho, conforme o art. 4 da MP 927/20.

\footnotetext{
Art. $4^{\circ}$ Durante o estado de calamidade pública a que se refere o art. $1^{\circ}$, o empregador poderá, a seu critério, alterar o regime de trabalho presencial para o teletrabalho, o trabalho remoto ou outro tipo de trabalho a distância e determinar o retorno ao regime de trabalho presencial, independentemente da existência de acordos individuais ou coletivos, dispensado o registro prévio da alteração no contrato individual de trabalho.
}

Diante disso, a flexibilização da legislação permitiu que as organizações adotassem o teletrabalho durante o distanciamento social, causado pela pandemia da COVID-19. Todavia, a MP n 927/20 não teve o cuidado com a proteção e a saúde do trabalhador. Assim, aplica-se a regra geral constante do art. 75-E e parágrafo único da CLT. 
Outra problemática com o teletrabalho no regime de exceção decorrente da calamidade pública pela Covid-19 e normatizado pela MP n ${ }^{\circ}$ 927/20 decorre no artigo 62, inciso III, da CLT, em que se aplica ao teletrabalho o previsto na regra geral (arts.75-A a 75E, da CLT). Embora não fosse necessário, o $\S 1^{\circ}$, do art. $4^{\circ}$ da MP $N^{o} 927 / 20$, dispõe expressamente sobre a aplicação do art. 62, inciso III, da CLT. Assim, o empregado, em regime de teletrabalho em função da pandemia do coronavírus, não registrará horário e não terá direito ao adicional de horas extras. Conclui-se no sentido de que não há incompatibilidade entre as regras sobre teletrabalho previstas na CLT e aquelas presentes na Medida Provisória $n^{0}$ 927, já que, nesta, a questão maior a ser enfrentada é a escassez de tempo para formalizações em função da calamidade pública, entendendo-se que devem ser preservados dois direitos sociais fundamentais: saúde e trabalho.

\section{CONCLUSÃO}

A tecnologia está em constante desenvolvimento, e isso tem trazido maior avanço ao mercado de trabalho e, consequentemente, novas modalidades de oferta. Essa busca por novos mecanismos que flexibilize a atividade laboral fez surgir o teletrabalho. É certo que esta modalidade busca minimizar o espaço entre a empresa e seus colaboradores, de modo que também se aproxima do público alvo através do trabalho a distância.

Com o advento da Reforma Trabalhista veio a modalidade de teletrabalho na qual o empregado pode realizar a prestação de serviços a distância com uso de meios da tecnologia da informação e comunicação - TIC. O trabalhador foi se adaptando a essas mudanças, as quais trouxeram vantagens e desvantagens. Embora o foco seja o benefício para o trabalhador, destacamos também as vantagens para as empresas. Há também que se destacar a relação de subordinação, pois existe uma falsa autonomia, tendo em vista a presença dos requisitos para a configuração do vínculo empregatício dentro do teletrabalho, conforme o parágrafo único do artigo $6^{\circ}$ da CLT. Percebeu-se que a noção clássica (subordinação jurídica) não oferece respostas para alguns casos em que o teletrabalho é prestado. Nesses casos, aventou-se a possibilidade de utilização da ideia de subordinação estrutural, até porque a subordinação objetiva pode trazer algumas dificuldades.

Todavia, o teletrabalho ficou prejudicado com o acréscimo do inciso III ao artigo 62 da CLT, pois, desobriga do controle de jornada prevista no artigo 62, III. Entretanto, o estudo realizado mostra claramente o controle de jornada por meio de equipamentos eletrônicos, mesmo que o trabalho seja realizado à distância. Sobretudo, é preciso atentar à vulnerabilidade do teletrabalhador que necessita de maior proteção jurídica. 


\section{REFERÊNCIAS}

ALVES, Rubens Valtecides. Teletrabalho: um conceito complexo no Direito brasileiro. Revista do Curso de Direito da Universidade Federal de Uberlândia, Uberlândia, ano 10, 2007.

BOMFIM, Volia Cassar. Resumo de direito do trabalho. 6. ed., rev., atual. e ampl. São Paulo: Método, 2018.

BRASIL. Decreto-Lei $n^{\circ} 5.452$, de $1^{\circ}$ de maio de 1943. Aprova a Consolidação das Leis do Trabalho. Disponível em: http://www.planalto.gov.br/ccivil_03/DecretoLei/Del5452.htm. Acesso em: 28 nov. 2020.

BRASIL. Presidência da República - Casa Civil - Subchefia para Assuntos Jurídicos. Lei no 13.979 de 06 de fevereiro de 2020. Disponível em: http://www.planalto.gov.br/ccivil_03/_ato2019-2022/2020/Lei/L13979.htm. Acesso em: 20 dez. 2020.

BRASIL. Congresso Nacional. Medida Provisória $n^{\mathbf{0}} 927$ de 2020. Disponível em: https://www.congressonacional.leg.br/materias/medidas-provisorias/-/mpv/141145. Acesso em: 20 dez. 2020.

BRASIL. Presidência da República - Casa Civil - Subchefia para Assuntos Jurídicos. Medida Provisória no $\mathbf{9 3 6}$ de 2020. Disponível em: http://www.planalto.gov.br/ccivil_03/_Ato2019-2022/2020/Mpv/mpv936.htm. Acesso em: 20 dez. 2020.

Constituição da República Federativa do Brasil, de 5 de outubro de 1988. Disponívelem: http://www.planalto.gov.br/ccivil_03/constituicao/constituicao.htm. Acesso em : 28 nov. 2020.

Lei $\mathrm{n}^{\circ}$ 13.467/2017, de 13 de julho de 2017. Altera a Consolidação das Leis do Trabalho (CLT), a fim de adequar a legislação às novas relações de trabalho. Brasília, DF. Disponível em: http://www.planalto.gov.br/ccivil_03/_ato20152018/2017/lei/L13467.htm. Acesso em: 28 nov. 2020.

Lei $\mathrm{n}^{\circ} 12.551 / 2011$, de 15 de dezembro de 2011. Altera o art. $6^{\circ}$ da Consolidação das Leis do Trabalho (CLT) para equiparar os efeitos jurídicos da subordinação exercida por meios telemáticos e informatizados à exercida por meios pessoais e diretos. Brasília, DF. Disponível em: http://www.planalto.gov.br/ccivil_03/_Ato20112014/2011/Lei/L12551.htm. Acesso em: 28 nov. 2020

CAETANO, Douglas. Passe na $\mathrm{OAB} 2^{\mathrm{a}}$ fase: prática trabalhista. 3. ed. São Paulo: Saraiva, 2019.

DELGADO, Mauricio Godinho. Curso de direito do trabalho. $7^{\text {a }}$ edição. São Paulo: LTr, 2008.

DELGADO, Maurício Godinho; DELGADO, Gabriela Neves. A reforma trabalhista no Brasil: com os comentários à Lei n. 13.467/2017. São Paulo: LTr, 2017.

DUTRA, Silvia Regina Bandeira; VILLATORE, Marco Antônio César. Teletrabalho e direito à desconexão. Revista Eletrônica do Tribunal Regional do Paraná, v. 3, p. 142-149, 2014. Disponível em: http://bit.ly/2Gj7Ujf. Acesso em: 7 dez. 2020. 
GARCIA, Gustavo Filipe Barbosa. Curso de direito do trabalho. 11. ed. Rio de Janeiro: Forense, 2017.

HOLZMANN, L. Trabalho a domicílio. In: CATTANI, A. D.; HOLZMANN, L. (Orgs.). Dicionário de trabalho e tecnologia. Porto Alegre: Zouk, 2011. p. 437-440.

JARDIM, Carla Carrara da Silva. O teletrabalho e suas atuais modalidades. 1. ed. São Paulo: LTr, 2004.

MAGALHÃES, Joalvo. Teletrabalho. In: Reforma Trabalhista: o mundo do trabalho em suas mãos. Rio de Janeiro: Curso Ênfase, 2017.

MARTINS, Sergio Pinto. Direito processual do trabalho. 35. ed. São Paulo: Atlas, 2014.

ORGANIZAÇÃO INTERNACIONAL DO TRABALHO (OIT). Convenio sobre el trabajo a domicilio. (n. 177). Disponível em: http://www.ilo.org/dyn/normlex/es/f?p=NORM LEXPUB: $\quad$ 12100:0: $\quad$ NO:12100: P12100_INSTRUMENT_ID:312322: NO. Acesso em: 05 dez. 2020.

PASCHOAL, G. H. Elementos de direito do trabalho. Curitiba: Instituto Memória, 2018.

RAVAGNANI, Christopher Abreu; RODRIGUES, Raphae 1 Marcos Baccaro. Os impactos da novel reforma trabalhista no teletrabalho. Revista Juris UniToledo, Araçatuba, v. 03, n. 02, p. 03-23, abr./jun. 2018.

ROCHA, B. S. Home office: o ponto de equilíbrio entre a qualidade de vida e a produtividade. 2014. Trabalho de Conclusão de Curso. Cesuca Faculdade Inedi.

SANTOS, Michel Carlos Rocha; MIRANDA, Michelly Cardoso. A eficácia horizontal dos direitos fundamentais: a proteção à intimidade e vida privada no teletrabalho em face de era virtual. Revista de Direito do Trabalho: RDT, v. 43, n. 175, p. 95-115, mar. 2017.

SILVEIRA E SILVA, Frederico. O teletrabalho como novo meio de laborar e sua compatibilidade com o ordenamento jurídico brasileiro. R. CEJ, Brasília, n. 27, p. 102-109, out. /Dez. 2004.

SILVA, Paulo Antônio Maia. Direito do Trabalho / Paulo Antônio Maia e Silva, Markus Samuel Leite Norat. 2. ed. Ver. E atual. - Leme: CL EDIJUR, 2012.

SCHWARZ, Rodrigo Garcia. Direito do trabalho. Rio de Janeiro: Elsevier, 2007.

WINTER, Vera Regina Loureiro. Teletrabalho: uma forma alternativa de emprego. São Paulo: LTr, 2005.

VALENTIM, João Hilário. Teletrabalho e relações de trabalho. Revista do Ministério Público do Trabalho, Brasília, $\mathrm{N}^{\circ}$ 19, p. 58-62, 2000. REV. MPT — BRASÍLIA, ANO X $\mathrm{N}^{\mathrm{o}} 19$ - mar. 2000. 


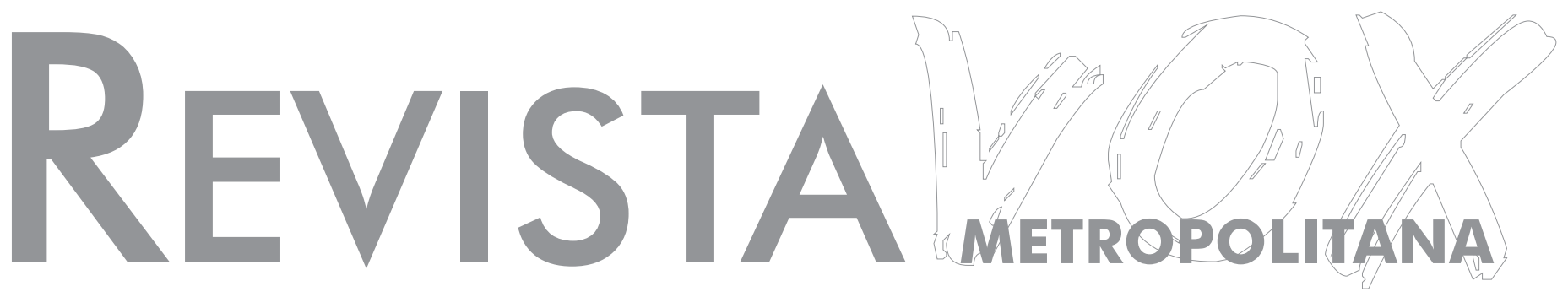

